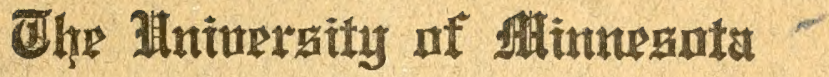

\section{MINNESOTA GEOLOGICAL SURVEY}

William H. Emmons, Director

IN COÖPERATION WITH THE UNITED STATES GEOLOGICAL SURVEY

BULLETIN NO. 14

\section{SURFACE FORMATIONS}

AND AGRICULTURAL CONDITIONS OF THE SOUTH HALF OF MINNESOTA

\author{
BY \\ FRANK LEVERETT \\ AND \\ FREDERICK W. SARDESON \\ WITH A CHAPTER ON \\ CLIMATIC CONDITIONS IN MINNESOTA \\ BY
}

U. G. PURSSELL

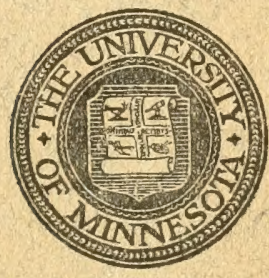

MINNEAPOLIS

The University of Minnesota

1919 



\title{
The Alniurreity of Althmegnta
}

\author{
MINNESOTA GEOLOGICAL SURVEY \\ William H. Emmons, Director
}

IN COÖPERATION WITH THE UNITED STATES GEOLOGICAL SURVEY

BULLETIN NO. 14

\section{SURFACE FORMATIONS \\ AND AGRICULTURAL CONDITIONS OF \\ THE SOUTH HALF OF MINNESOTA}

BY

FRANK LEVERETT

AND

FREDERICK W. SARDESON

WITH A CHAPTER ON

CLIMATIC CONDITIONS IN MINNESOTA

BY

U. G. PURSSELL

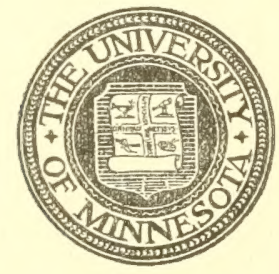

MINNEAPOLIS

The University of Minnesota

1919 


$$
545 ! v^{4}
$$

?. of $D$.

JUN 201919

$\because \vdots$ 


\section{CONTENTS}

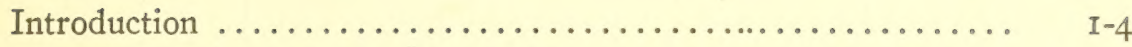

Chapter I. Physical features of Minnesota.............. 5-22

Topography of Minnesota.................... 5 5

General statement ....................... 5

Altitude ............................... 6

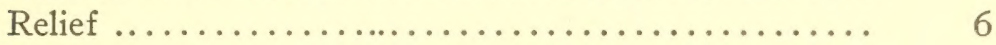

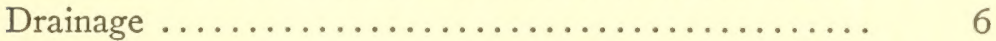

Lakes ................................. 7

Surface geology ........................ I0-I8

Rock areas ............................ Iо

The earthy mantle ...................... Io

General statement .................... ro

Residuary material ..................... II

Wind deposits ......................... II

Glacial deposits ....................... II

Stream deposits $\ldots \ldots \ldots \ldots \ldots \ldots \ldots \ldots \ldots \ldots \ldots \ldots$ I4

Lake deposits ....................... I4

The glacial features and their history............. I4

Glacial lake features..................... I6

General soil conditions..................... I8-22

Vegetation ............................. I9

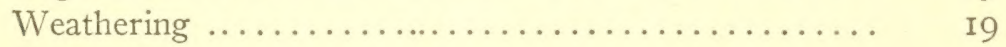

Lime...................................

Effect of fires........................ 2I

Chapter II. Climatic conditions................... 23-44

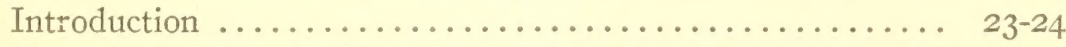

General climatic conditions................... 24-44

Temperature .......................... 24

Frosts ............................... 3 I

Precipitation ............................ $\quad 36$

Snowfall ............................ 40

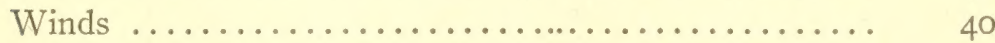

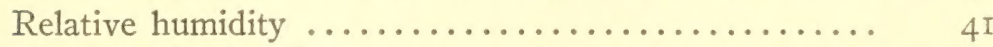

Number of rainy days....................... 4I

Sunshine...$\ldots \ldots \ldots \ldots \ldots \ldots \ldots \ldots \ldots \ldots \ldots$. 4 II

Chapter III. Agricultural conditions and land classification in the south half of Minnesota........................ 45-62

General statement ........................... 45

Driftless area .......................... 45-46

Loess-covered pre-Wisconsin drift................ 46-47 
Old gray drift (Kansan) with little or no loess cover.......

Iowan drift over Kansan drift................ 47-48

Old red drift (Illinoian) over old gray drift (Kansan).... 4 48-49

Young or Wisconsin red drift (Patrician ice sheet)...... 49-50

Young or Wisconsin red drift (Labradorian ice sheet)..... 50

Border of young gray drift (Keewatin ice sheet) in central

Minnesota ......................... 50-5I

Border of young gray drift in southwestern Minnesota.... 5 5

Moraines of southwestern Minnesota............ 52-53

Moraines of southeastern Minnesota............... 53

Overlap of red drift by gray drift in Grantsburg lobe. . . . . . 53-54

Gray drift moraines of central Minnesota........... 54-55

The great plain of the Minnesota lobe............. 55-56

The great Red River plain.................. 56. 56. 57

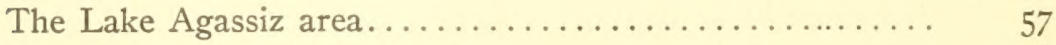

Outwash sand and gravel plains.............. 57-58

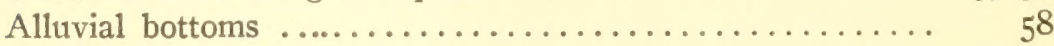

Farming development in Minnesota.............. 58-60

Rank of different crops in Minnesota. . . . . . . . . . . . 60-62

Relation of crop values to farm investments in southern Min-

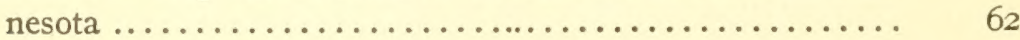

Chapter IV. Descriptions of counties............. $63^{-142}$

Pine County .......................... 63-64

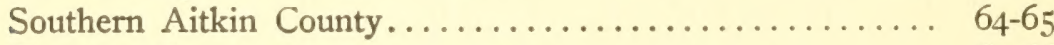

Kanabec County ......................... 65-66

Mille Lacs County........................... 6. 66-67

Southern Crow Wing County................ 67-68

Southern Cass County........................ 68

Morrison County ....................... 68-70

Todd County ........................ 70-71

Southern Otter Tail County................. 7 I 7 -72

Douglas County ........................ 72-73

Grant County ........................... 73-74

Wilkin County .......................... 74-75

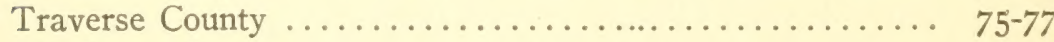

Big Stone County ....................... 77-78

Stevens County ........................ 78-79

Pope County ......................... 79-8I

Stearns County ..................... 8I-82

Benton County ........................ 82-83

Sherburne County ...................... 84-85

Isanti County $. \ldots \ldots \ldots \ldots \ldots \ldots \ldots \ldots \ldots \ldots . \ldots \ldots$ 85-86 
Anoka County ............................ 86-87

Chisago County ......................... 87-88

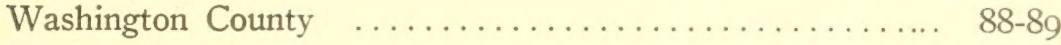

Ramsey County ........................ 8 89-90

Hennepin County ........................ $9 \mathrm{I}-92$

Wright County ........................ 92-93

Meeker County ........................ 93-94

Kandiyohi County ......................... 95

Swift County .......................... 96-97

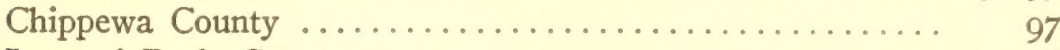

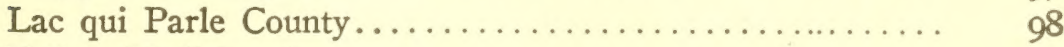

Yellow Medicine County...................... 99

Renville County ........................... Io

McLeod County ........................... IOI

Sibley County ....................... IOI-2

Carver County ........................ I02-3

Scott County ........................... 103-4

Dakota County ........................... 104-6

Goodhue County ........................ 106-9

Rice County .......................... IO9-I I

Le Sueur County........................ III-I2

Nicollet County ........................ II 2 II

Brown County ......................... II 3 -I4

Redwood County ......................... II4-I5

Lyon County .......................... II

Lincoln County ............................ II6-I7

Pipestone County ....................... II7-I9

Murray County ......................... II9-20

Cottonwood County ..................... I20-21

Watonwan County ....................... I2I-22

Blue Earth County...................... I22-24

Waseca County ......................... $124-25$

Steele County . . . . . . . . . . . . . . . . . . . $125-26$

Dodge County ........................... 126-27

Olmsted County ....................... I27-28

Wabasha County .......................... I28 29

Winona County ...................... I29-31

Houston County ....................... I $3 \mathrm{I}-32$

Fillmore County ....................... I ${ }^{2} 32-33$

Mower County .......................... I $133-35$

Freeborn County ........................ I35-36

Faribault County ........................ I $36-37$ 


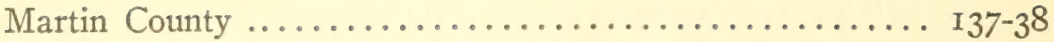
Jackson County .......................... I38-39 Nobles County ........................ I39-4I Rock County ......................... I4I-42 


\section{LIST OF ILLUSTRATIONS}

Plate I. Map of the surface formations of Minnesota..... in pocket

II. A. Bed of Lake Agassiz near Wheaton

B. Grain field in bed of Lake Agassiz near Wheaton

C. Gray drift till plain in Chisago County....... 58

III. A. Cultivated red drift till plain near Foley

B. Red drift till plain with forest near Foley

C. Boulders on red drift till plain near Foley.....

62

IV. A. Gray drift moraine north of St. Paul

B. Red drift moraine with coating of gray drift north of St. Paul................. 90

V. A. Wisconsin, or young red drift, moraine near Stillwater

B. Old red drift moraine near Hampton........

VI. A. Outwash plain east of Anoka

B. Outwash plain of gray drift west of White Bear

C. Outwash plain with thick clayey covering north of St. Paul...................... 94

VII. A. Slope of the Coteau des Prairies near Canby. Gray drift moraine

B. Eroded upland in old gray (Kansan) drift northeast of Zumbrota

C. Broad valley cut in old gray (Kansan) drift west of Kenyon................... 108

VIII. A. Loess-covered driftless area near Caledonia

B. Valleys bordered by limestone tablelands near

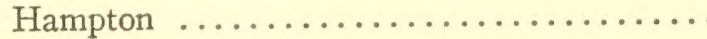

IX. A. Zumbro valley near Rochester

B. Valley of Rollingstone River near Minnesota City

C. Mississippi valley at Minnesota City........ I40 


\section{TEXT FIGURES}

Fig. I. Altitude map of Minnesota................. 8

2. Map of glacial drifts, loess, and glacial lakes......... I3

3. Map showing distribution of forest and prairie........ 20

4. Map showing mean annual temperatures............. 25

5. Map showing mean temperatures for January........ 27

6. Map showing mean temperatures for July.......... 28

7. Map showing highest known temperatures.......... 29

8. Map showing lowest known temperatures............ 30

9. Map showing average date of last killing frost in spring. . 32

Io. Map showing average date of first killing frost in autumn 33

II. Map showing number of days of the average crop-growing

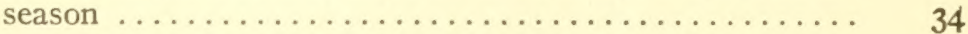

12. Map showing the average annual precipitation......... 35

13. Diagram showing comparative monthly precipitation.... 37

14. Diagram showing mean monthly rainfall and mean monthly temperatures at several stations.............. 38

15. Diagram showing rainfall and temperatures at St. Paul

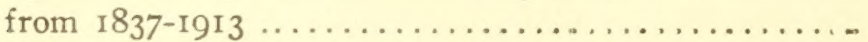




\title{
SURFACE FORAIATIONS AND AGRICULTURAL CONDITIONS OF THE SOUTH HALF OF MINNESOTA
}

By Frank Leverett and Frederick W. Sardeson

\section{INTRODUCTION}

\author{
By W. H. EMMONS
}

Soil is the loose unconsolidated material which nearly everywhere covers the surface of the earth and in which plant life may be maintained. It is made up of finely divided rock in which decaying vegetable matter and animal matter are mingled. A soil is generally in a state of change. It is being washed little by little to the creeks and rivers which carry it to the sea, where it often forms delta deposits; if no new soil formed, hard rock would finally be exposed instead of the loose plant-producing soil. But rocks at and near the surface are continually changing and new soil is being formed from the underlying rock or from loose clayey or gravelly material that may constitute the subsoil, or from bowldery material that at many places in Minnesota lies between the hard rock and the soil.

Water and air attack rock matter and break it down. Heat and cold, freezing and thawing, shatter the rocks and give plants an opportunity to send roots into the cracks that are formed, and these, prying the rocks apart, reduce them to particles of still smaller size. Even the hard solid rocks are ultimately broken down; a building of good solid stone may crumble in a few hundred years, especially in a moist climate.

Some of the rocky matter is dissolved by the water and carried to the sea in solution. It is such dissolved material that makes water "hard" and that gathers in the bottom of a vessel when water is boiled. But not all of the soluble substances are dissolved and carried away; some remain in the soil, and the character of the soil depends largely upon these. Some soils are acid because they have not enough lime. Some are deficient in potash or phosphates, which are necessary if soil is to produce certain crops satisfactorily.

Because it forms the soil, the composition of the underlying material is of great importance. In . Iinnesota most of the soil is the weathered portion of glacial drift or of lake beds and other features connected with the deposition of the drift. Long ago nearly all of what is now the state of Minnesota was covered over with a great ice shect hundreds of feet thick that slowly moved down from the Canadian highland carrying with 
it rocky material which it had gathered in the north. When the ice melted it left large quantities of rock and soil that had mingled with the ice, and this material is the loose drift that lies between the hard rock and the surface. At many places where it is not yet disintegrated it appears as large numbers of bowlders mixed with clay. Although the ice sheet moved very slowly, perhaps not more than a few rods a year or even less, it was active for a long period and locally it scoured the country clean of soil and loose material which, on melting, it piled up somewhere else.

This statement of the origin of the loose material or drift is not speculation, but is substantiated by the most convincing facts. The deposits and all of the features of the country formerly covered with ice are like those that may now be observed in Greenland or Antarctica, where the slowly moving ice fields or glaciers still cover bodies of land of continental proportions. Glacial bowlders, bowlder clay, scratches on the rocks, morainal hills and kettles, all ordered with respect to definite features of the former ice sheet, may be seen at thousands of places in Minnesota.

The ice sheet covered the entire state of Minnesota except the southeastern corner, embracing Houston County and the eastern part of Winona County. This territory is in the driftless area. The higher country within the driftless area is covered with a residuary clay formed during the long period when the rock was undergoing decay. Above this there is generally a covering of wind-blown silt-loam, or loess, which increases the productivity of the soil.

The advance of the ice toward the south was not a single isolated invasion. There were warm periods during the glacial epoch when the ice melted much faster than it advanced, and when the edge of the ice retreated far to the north. Probably the entire ice cap was melted several times during the long period of the ice invasions.

During the intervals when the country was free from ice, rock decay or weathering went on much as at present. Later the succeeding ice sheets covered the larger portions of these weathered surfaces, within the glaciated region. The later ice sheets, however, did not cover exactly the same areas that were covered by preceding ones. In places the deposits left by older ice sheets project beyond the edges of the deposits left by later ones. One may distinguish between them by the difference in the amounts of their decay and in some cases by differences in their material and in the character of the topography of their surfaces. Where deposits of one sheet are covered by those of a later one, the older drift sheet may be revealed where streams cut through the later one or where excavations penetrate it. At some places an ancient soil formed by rock 
decay and carrying the remains of ancient vegetation marks the contact between the older and the younger drift. The boundaries of the drifts of various ages and the character of the soils formed by them are discussed on pages that follow.

Swamps are very numerous in Minnesota. They are portions of the old lake beds and other poorly drained areas and are of little value for agriculture until drained. Since the ice melted a growth of vegetation has been established on them and great thicknesses of partially decayed vegetation have accumulated in them. This forms the peat which is found in so many of the swamps. Some of it is very thick and will doubtless become a valuable asset in the future when other fuels shall have become more costly.

The great productivity of Minnesota soils is due, not only to their recent origin by reason of which nearly all of them still contain the soluble mineral foods for plants, but also to a favorable climate. The low temperatures which frequently prevail during certain periods in winter make for healthful conditions for animal life and they also benefit plant life. The rainfall, though not excessively great, is sufficient and, since most of it occurs during the growing period, drouths are rare and crop failures almost unknown except in the more sandy soils, which are, however, adapted to quick-growing crops like potatoes. As shown herein, the length of the crop-growing season, that is, the time between late spring frosts and early autumn frosts, is between 100 and I\%O days for all except the extreme northeast corner of the state. The long days, high proportion of sunshine, and the moderate humidity are all favorable to plant growth.

This bulletin treats the soils of only the south half of Minnesota. The field embraced includes the part of the state south from the median line, which is near latitude $46^{\circ} 25^{\prime}$.

Following the plan in Bulletin No. I2, on Northwestern Minnesota, a brief general description of the surface features and deposits of the entire state is given, and the climate of the entire state also is discussed. It will be followed by a report on the entire state, the field work for which already has been completed. The work has been done in accordance with the agreement for coöperation between the United States Geological Survey and the Minnesota Geological Survey, entered into, March, I9I2. By this agreement the services of Mr. Frank Leverett were secured for surveying the surface formations and soils. Mr. Leverett has been engaged since I886, or thirty-two years, in studying the surface geology of the Great Lakes region and because of his large experience in the greater area he was particularly well prepared to undertake the studies in Minnesota. He has spent, moreover, considerable time in the state studying its 
physiography in connection with the preparation of a monograph for the United States Geological Survey. Since the reorganization of the State Survey, the salary of Mr. Leverett has been met by the United States Geological Survey, while the greater part of his expenses have been paid by the State Survey. The State Survey has provided also for this work the services and expenses of Professor F. W. Sardeson, who has assisted in this work for five seasons. We wish to acknowledge the generous assistance of the Division of Soils of the Department of Agriculture of the University of Minnesota and of the United States Bureau of Soils. The valuable contributions to the knowledge of the surface formations of Minnesota by the Minnesota Geological and Natural History Survey, under the direction of Professor N. H. Winchell, particularly those of Mr. Warren Upham of that survey, have aided greatly in the preparation of this report. The section on climatic conditions in Minnesota has been generously contributed without any cost to the Survey by Mr. U. G. Purssell, Director of the Minnesota Section of the United States Weather Bureau. In the preparation of the maps and other data showing dates of lilling frosts, lengths of growing season, rainfall, etc., Professor C. J. Posey has rendered efficient service.

The cost of preparation of this report has been met by the Minnesota Geological Survey and the United States Geological Survey. This bulletin is printed by the Minnesota Geological Survey. Arrangements have been made so that land and colonization companies can secure these reports at actual cost of printing, and it is expected that this arrangement will secure a wide distribution. The maps are not intended to be used as a basis for the purchase of land; they do not give an accurate description of each forty-acre tract or each section, but they show the general classification of the land. its climate, and its surroundings. 


\section{CHAPTER I \\ PHYSICAL FEATURES OF MINNESOTA}

\section{TOPOGRAPHY OF MINNESOTA}

\section{GENERAL STATEMENT}

The position of Minnesota is near the center of the North American Continent, and the state embraces an area of $\delta_{4}, 68_{2}$ square miles, of which about 93 per cent is land and 7 per cent water. Its extreme length is nearly 400 miles, from latitude $43^{\circ} 30^{\prime}$, at the Iowa line, to a point about 23 miles north of the 49th parallel, in the projection known as the Northwest Angle, northwest of Lake of the Woods. The greatest wilth is 367 miles, but the average width is only about 225 miles, or but little more than half of the length.

Minnesota presents more variety in surface features than most of the north central states, yet a great part of its surface is level or only gently undulating. The flattest portion falls largely in the northwest quarter, and was once the bed of the glacial Lake Agassiz, a lake held in on the north, in central Canada, by the great ice sheet. The roughest portion is in the northeastern quarter. This part is composed largely of volcanic formations and iron-bearing rocks which, though glaciated, were not everywhere buried beneath the glacial deposits. In the southeastern part of the state deep erosion valleys along the Mississippi and its tributaries present bold rock bluffs 300 to 600 feet high. The interior and southern parts of the state have features due almost entirely to the work of the great ice sheets, which at successive times, and from different directions, overspread Minnesota. The glacial deposits comprise an intricate system of moraines with undulating to hilly surface, associated with which are level outwash plains of sand and gravel, and gently undulating intermorainic till plains. The moraines were formed along the border of the ice at definite lines where the edge of the ice held its position for a relatively long time. They consist of sharp knolls and incloserl basins and also of more or less parallel ridges which, however, interlock in places. These moraines are distributed in rudely concentric systems which mark successive positions of the border of each ice sheet as it was melting off from this region. The outwash plains lie on the outer border of the moraines, where sandy gravel was spread out by dirt-laden waters escaping from the ice. The till plains lie along the inner or iceward border of the moraines and represent areas over which the ice border melted back somewhat rapidly, forming relatively few knolls and ridges. 
ALTITUdE

The altitude of Minnesota ranges from 602 feet, the level of Lake Superior, up to 2,230 feet, on high rock hills in the northeast part of the state, in western Cook County. The small map, Figure I, shows that a large part of the state falls between $I, 000$ and $I, 500$ feet. The average altitude of the state is not far from $I, 200$ feet. The portions above 1,500 feet lie chiefly in two areas, one at the northeast and one at the southwest corner of the state, though there is a good sized area around the sources of the Mississippi River in the western part, and several smaller areas in that vicinity; one of these in the southern part of Otter Tail County is known as the Leaf Hills. The altitude of the elevated area in the southwestern part falls short a little of reaching 2,000 feet, but that in the northeastern part includes several small areas, chiefly in Cook County, that rise above 2,000 feet. The portions below I,000 feet fall in two areas widely separated except for a connecting line along the Minnesota valley, one being on the western edge of the state and the other on the castern. There is also a narrow strip bordering Lake Superior.

\section{RELIEF}

The most conspicuous relief is found in the "Sawtooth Range" and other prominent ridges that closely border Lake Superior and which rise abruptly from 500 to 900 feet above the lake. The rock ranges lying back from the shore, though more elevated than those fronting on the lake, seldom rise more than from 200 to 300 feet above the swamps and lakes among them. In fact several of the lakes of Cook County are above 1,900 feet or within 300 feet of the level of the highest points in the state. The most prominent part of the Mesabi Iron Range in St. Louis County rises from 400 to 450 feet above bordering plains. The Coteau des Prairies rises about joo feet above the plain northeast of its border, but in Minnesota the rise is ustually spread over a space of from I 2 to 15 miles or more in width, so that the elevation can scarcely be appreciated by one crossing over it. There is a rather rapid rise of from 300 to 500 feet to the sharp range of hills in Otter Tail and Becker counties from the Red River valley. This rise is of especial interest since it seems to have some influence on the rainfall, the precipitation being greater in these hills where air currents are forced upward and cooled than in the bordering lower lands to the north, west, and south.

\section{DRAINAGE}

The drainage of Minnesota is widely divergent, part of it leading to the Gulf of Mexico, part to the Gulf of St. Lawrence, and part to Hudson Bay. The Gulf of Mexico receives about 57 per cent, the St. Lawrence less than 9 per cent, and Hudson Bay fully 34 per cent of the drain- 
age. There was a time, however, after the glacial ice had melted from Minnesota but was still occupying the northeast part of the Superior basin and neighboring parts of Ontario and Manitoba, when all the drainage was southward to the Gulf of Mexico. The western Superior basin then overflowed into the St. Croix River, while the Red River drainage basin, largely covered by Lake Agassiz, drained southward through lakes Traverse and Big Stone into the Minnesota valley.

The drainage to the south, or Gulf of Mexico, has generally a gentle descent, and waterfalls are rather rare, though the Mississippi has notable falls at Minneapolis and there are one or more falls or rapids on several of the tributaries. The drainage to Lake Superior is generally rapid and nearly every stream has several cascades. There is, however, a wide area of the upper St. Louis basin in which that stream and its tributaries have relatively gentle descent for many miles. The Hudson Bay drainage has a few rapids and waterfalls in the headwater part of Rainy River and its tributaries, but Red River and its main Minnesota affluent, Red Lake River, have no falls since no outcrops of solid rock occur along them. There is, however, very rapid descent for a few miles along Red Lake River and its tributary Clearwater River in Red Lake County. Red River is subject to great freshets because its lower course often remains frozen after the southern or headwater part has broken up. Thus ice jams are formed which divert the waters from the channel over the bordering plain.

The streams of these several drainage systems are interwoven in part of the area, there being no prominent dividing ridges to separate them. In some cases a swamp may be drained either to Hudson Bay or to the Gulf of Mexico, while other swamps may be drained either to the Mississippi or to Lake Superior.

\section{LAKES}

Throughout much of Minnesota, except the northwest, southwest, and southeast corners, smail lakes are a common feature. They usually occupy basins among the moraine ridges and knolls and on the outwash plains, but occur to some extent also on the till plains and among rock knobs. The combined area of the lakes within the state is estimated to be about 5,650 square miles, or nearly 7 per cent of the entire area. The largest lake is Red Lake, a very shallow body of water with an area of 440 square miles. Other large lakes are Mille Lacs, also very shallow, Leech, Winnibigoshish, and Minnetonka. Minnetonka and the southern part of Leech Lake extend into a network of deep depressions among morainic ridges, but the other lakes are largely in plains that are slightly below the neighboring districts, partly morainic and partly plain. 


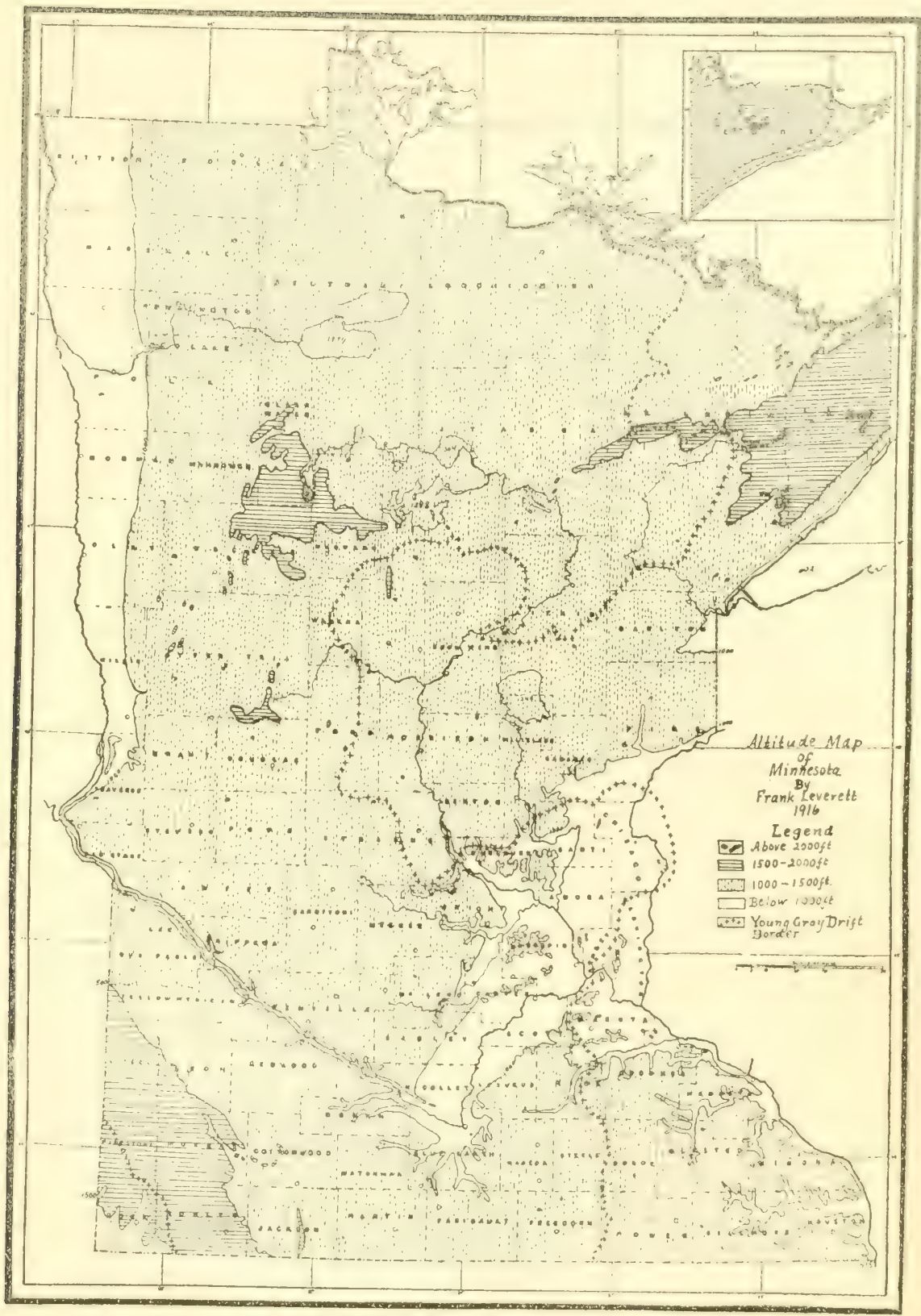

FIGURE I. ALTITUDE MAP OF MINNESOTA 


\section{EXPLANATORY NOTE, FIGURE I}

This map shows the great extent of land in Minnesota standing between 1,000 and $\mathrm{I}, 500$ feet above sea level, as well as the distribution of the higher areas and of areas standing below $\mathrm{I}, 000$ feet.

It shows also the effect of low areas in favoring the movement of the latest invasion of ice from the north, that which deposited the young gray Keewatin drift, as well as the effect of the high areas in checking the movement. The great axial movement of the ice was through the low-lying Red River basin, much of which is below I,00o feet, and thence down the Minnesota valley to the great bend at Mankato over a plain much of which is below I, I00 feet. The thumb-like offshoot of the ice, in a lobe extending from Wright and Hennepin counties northeastward across Anoka, Isanti, and Chisago counties, into the edge of Wisconsin, was apparently induced by an exceptionally low area, largely below 1,000 feet, over which it passed. In northern Minnesota the ice passed over the relatively low land, I,200 to I,300 feet, along and near the Mississippi River in Cass and Itasca counties, into the St. Louis River basin in St. Louis County, and down the Mississippi in Aitkin County; but it was so checked by higher land, I,500 to 1,750 feet, in Clearwater, Becker, and Hubbard counties, that it could there reach only southeastern Hubbard and neighboring parts of Cass and Wadena counties. The Mesabi Range also held the ice border back nearly to the western edge of St. Louis County while it pushed eastward some distance in St. Louis County, both north and south of the range.

The topography also influenced ice movement in the northeast part of the state. There was a strong movement of ice southwestward through the Superior basin, with its northwest border only a few miles back from the shore on the high land, much of which stands I,500 feet or more above the sea. This high land was largely covered by ice moving southward from the neighboring part of Canada. The relations of this ice movement to that in the Superior basin, as well as to that which covered western Minnesota is set forth in the discussion of the glacial deposits. 


\section{SURFACE GEOLOGY}

ROCK AREAS

The areas in which rock is so exposed as to render the land untillable are largely in the northeast quarter of the state, or along valleys in the southeast quarter. The northwest quarter is estimated to have less than ro square miles of bare rock outcrop, and the southwest scarcely roo square miles. It is doubtful if there is an area of $\mathrm{r}, 000$ square miles in the entire state in which the plow would generally strike into rock ledges. The rock areas thus form a much smaller percentage of the state than the lake areas. The rock areas of the northeast part are chiefly rock bosses standing above the surrounding land, but the beds of the streams that lead directly down to Lake Superior are also usually on rock ledges. Among the rock knobs are some depressions covered only with moss and peaty material, glacial material being scanty, but ordinarily some glacial material is present and nearly all the land has soil enough over the bedrock to support a rich forest growth. Many of the knobs preserve the smooth surface left by the scouring effect of the ice sheet and are nearly destitute of vegetation. But certain others have become disintegrated to a depth of several inches or even to several feet from the surface and are supporting growths of vegetation of considerable density.

The rock areas of the southwest part of the state are largely of Sioux quartzite which in places comes to the surface over areas of several square miles. The rocks have scarcely enough soil over them to support the scanty vegetation. There are a few small areas of granite knobs along the Minnesota valley from Big Stone Lake down to New Ulm. In the driftless area and part of the drift-covered area in southeastern Minnesota, rock ledges of limestone and sandstone outcrop along the steep slopes of the valleys, often forming walls of considerable height. Rock is rarely exposed along the stream beds and valley bottoms. The uplands and the higher parts of the slopes of the valleys even in the driftless area usually have several feet of residuary clay and also a coating of loess or wind-deposited silt loam covering the rock formations and rendering the land tillable.

\section{THE EARTHY MANTLE}

GENERAL STATEMENT

The variety of earthy, sandy, and gravelly unconsolidated deposits which cover the rocky floor of Minnesota were formed or deposited by different agencies and at different times. They may be grouped as follows: 
First. Residuary material.

Second. Wind deposits.

Third. Glacial deposits.

Fourth. Stream deposits.

Fifth. Lake deposits.

RESIDUARY MATERLAL

The residuary material, as its name implies, has been left as a residue during the breaking down or decay of the surface rocks through weathering and solution. On limestones it is usually a dark, reddish brown, gummy clay, but on sandstones and crystalline rocks it is usually grantlar and loose-textured. There is but a small part of Minnesota, chiefly in the southeastern counties, where residuary material is within reach of the plow. It occurs there on the upper part of the slopes of the valleys and on the narrow upland strips between valleys, but it is usually covered by loess.

\section{WIND DEPOSITS}

Loess.-The wind-deposited material known as loess is largely a fine silt loam, which forms the surface in an area in the southeast part of the state embracing much of Goodhue, Olmsted, Wabasha, Winona, Fillmore, and Houston counties and parts of Mower, Dodge, Rice, and Dakota counties. It covers a small tract in the southwest part of the state. In the southeastern counties it rests in part on glacial drift deposits and in part on the residuary clay and rock formations of the driftless area. In the southwestern part it covers glacial deposits. In the southeast district its border is very irregular, there being long strips of loess-covered land projecting westward or northwestward into the region free from loess, and also long strips free from loess extending eastward into the loess-covered tracts. The condition there is such as might result from the presence or absence of vegetation giving different degrees of protective power from the wind; areas with dense vegetation being able to hold dust that settled from the atmosphere while bare ones allowed it to be gathered up and carried on.

Wind-blown sand.-Wind-blown sand is also an important deposit. It embraces a district east of the Mississippi from Minneapolis up to Brainerd. It is narrow above St. Cloud, but below that city extends eastward to the St. Croix River. The sand does not, however, cover the entire surface in this area. Where present it rests upon glacial deposits. It has low ridges seldom 20 feet and usually Io feet or less in height. There is more or less wind-drifted sand in the sandy parts of the St. Louis River drainage basin, but it is sparingly developed compared to 
that in the district between the Mississippi and St. Croix rivers. Windblown sand occurs also in Aitkin County in the vicinity of McGregor and also in the northeastern part of the county in island-like tracts that are surrounded by marshes. There are numerous small areas of such sand scattered over the state, some of them being along the shores of the glacial Lake Agassiz.

GLACIAL DEPOSITS

The glacial deposits as shown in Figure 2 extend over the entire state except eastern Winona County and the greater part of Houston County, which are in the driftless area of the upper Mississippi. They underlie the wind-deposited sands and much of the loess area. They also underlie stream deposits and lake sediments. The glacial deposits are separable into till or bowlder clay in whith stones, clay, and sand are closely commingled; and into sand or gravel beds which show some assorting and bedding by water action. The percentage of stony material varies greatly and the matrix also shows variations from compact clay to loose sand. These variations are to be expected in a deposit that had been formed from the dirt and stones induded in an ice sheet. Every observing famer has probably noted and perhaps speculated upon the cause for these variations in the dritt deposits which form the basis for so large a part of the Minnesota soil. The assorted sand and gravel beds are largely due to waters escaping from the melting ice and many of them may be traced up to a moraine which marlied the position of the ice border at the time they were laid down. They show a decrease in coarseness in passing away from the edge of the moraine, the coarse material having been dropped close to the edge of the ice and only the fine carried to a great distance outside.

The glacial deposits also show some variations that relate to the kind of rock formations over which the ice passed. Thus, the northeastern portion of the state has a rather stony drift from the volcanic and hard crystalline rocks of that region. This stony material was carried as far south as Dakota County and forms the red drift of eastern and northeastern Minnesota. As indicated below, the red drift is the product of more than one ice sheet. The western and southern parts of the state have a large amount of clayey drift material with limestone pebbles imbedded. This material was gathered by this ice as it passed in its southward course from the shales and limestone of southern Manitoba, into the area of granite and other crystalline rocks. These clayey and limy deposits form what is known as the gray drift of Minnesota, and the ice sheet which formed it, as the Keewatin ice sheet. 


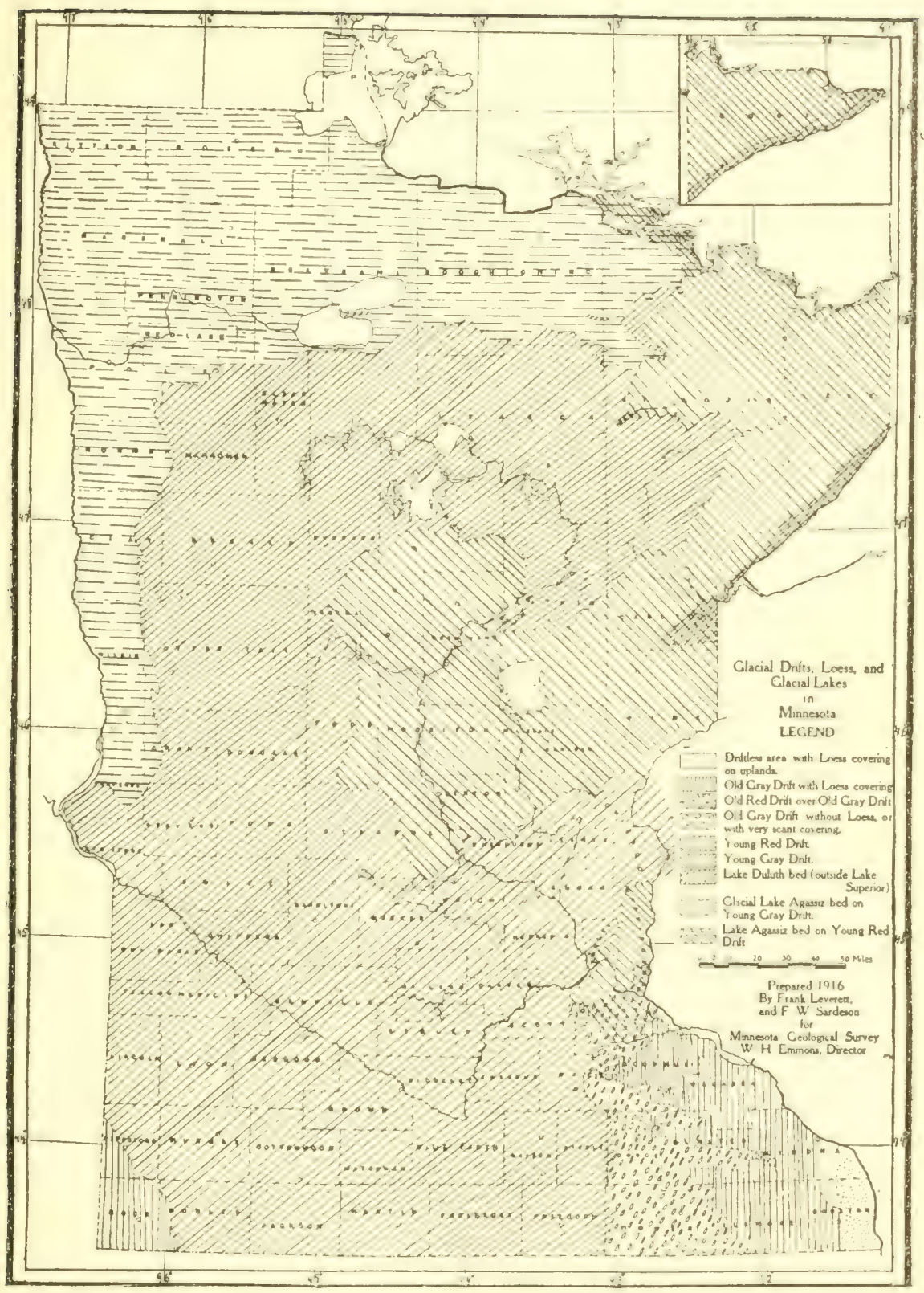

FIGURE 2. MAP OF GLACIAL DRIFTS, LOESS, AND GLACIAL LAKES IN MINNESOTA 
The stream deposits, being restricted to the valleys, are of limited area, though in such valleys as the Minnesota and Mississippi they are locally several miles in width and form important agricultural belts. On the Minnesota and the part of the Mississippi below the confluence with the Minnesota the deposits made by the rivers are sand or silt. On the Mississippi above the mouth of the Minnesota the deposits range from sand to coarse cobble and bowlders in correspondence with the swiftness of the stream. On nearly all the tributaries of the Mississippi and Minnesota the streams are able to carry coarse as well as fine material. Along the Red River a considerable amount of fine clay and clay loam has been deposited in seasons of flood on the plains outside the immediate river channel. The deposits made by glacial streams or those which had their sources at the edge of the ice and were receiving much of their water from the melting ice, now appear usually as terraces along the valleys above the limits of floods. From the fact that the glacial rivers were of greater volume these deposits are generally composed of sandy and gravelly material somewhat coarser than that carried by the present rivers.

\section{LAKE DEPOSITS}

The lake deposits consist of fine sediments washed into the deep parts of the lakes, and sandy and pebbly deposits washed up and formed into beaches along the shores. In parts of the lakes where the glacial deposits which they covered were pebbly and the water was shallow enough for wave action, there was a concentration of stony material by the washingout of the finer material. By this process considerable areas of the bed of Lake Agassiz were covered by very pebbly beds several inches in depth. They are clissed on the soil maps as "lake-washed till." In the narrow strip along the shore of Lake Superior that was covered by the waters of a glacial lake known as Lake Duluth, there is very little fine sediment; gravelly and cobbly beaches were formed at several successive levels, while fine material was washed down into the decper parts of the basin covered by the present lake. Fine material also covers the old lake plain in Carlton County and a strip on the south side of Lake St1perior.

\section{THE GLACIAL FEATURES AND THEIR HISTORY}

It has been found through a study of the deposits in Minnesota and neighboring states that the glacial deposits which form so cxtensive a mantle in Minnesota are the result of more than one invasion of the ice from the Canadian highlands. $\Lambda$ t each invasion the ice left a deposit of drift gathered partly from Canada and partly from the deposits over which it passed in Minnesota. The advances were so widely separated 
in time that the drift deposits of one invasion had large valleys cut in them by the action of streams before the next invasion occurred. The later advances failed to reach the limits of the earlier deposits, so they are still exposed to view, and the degree of erosion of the surface of the older can be compared with that on the surface of the younger deposits. It is found that the older drifts have been so greatly eroded and are so ramified by drainage lines that no lakes or undrained basins remain on them, while the younger drift deposits have numerous lakes and undrained basins and also large, poorly drained areas which the streams have not yet reached. It is because they are not covered by the latest drift that Rock and Pipestonc counties in southwestern Minnesoti, and Goodhue, Dodge, Wabasha, Olmsted, Winona, Iillmore, and Mower counties in southeastern Minnesota have no lakes and basins such as characterize neighboring counties that were covered by that drift.

The invasions of the ice into Minnesota not only took place at different times, but have come from more than one direction at about the same time. In the earlier invasions the greater part of the state was covered by ice coming from Manitoba as shown by limestone fragments and pebbles derived from ruck formations of that country which are imbedded in the lower part of the drift over all of the state except its northeast part. The movements in the closing stage of the glacial epoch were more largely from the northeast, but more than half of the state was invaded from the northwest. The ice sheets were as follows: r. The Superior lobe of the Labrador ice sheet, an extension of ice southwestward from the Superior basin nearly to Mille Lacs Lake; 2. The Patrician ice sheet, with southward movement from the highlands north of Lake Superior across eastern Minnesota to points a little beyond St. Paul ; 3. The Keewatin ice sheet, which moved southward through Manitoba and across western Minnesota. After the melting away of the ice that cane from the northern highlands, the Keewatin ice sheet extended over some of the ground that ice had vacated. It crossed the Mesabi Range into the St. Louis basin, and also moved northeastward from near Minneapolis into Wisconsin. This advance over earlier drift deposits is known from the presence of a thin deposit of clayey and limy drift containing rock material brought from Manitoba which covers the drift that was deposited by ice coming from the highlands northwest of Lake Superior. The drift from these highlands together with that from the Lake Superior basin forms the stony red drift of eastern Minnesota, while that from Manitoba forms the clayey and limy gray drift which covers almost all of the remainder of the state.

That the ice mass moved in different directions at diffcrent times in certain parts of the state is further shown by striations or ice markings 
on the surfaces of the rock ledges. In the district east and south of the Lake of the Woods a set of glacial grooves or ice markings bears west of south, while a newer set crosses them in an eastward or southeastward direction. The older set was formed by ice moving into Minnesota from the highlands that lie between Lake Superior and Lake Winnipeg, while the younger set was formed by ice moving into the state from Manitoba. In North Minneapolis there are rock ledges on which the glacial grooves have three courses; first, a southeastward course at the time when the old gray drift which came from the northwest was brought in; second, a southward course at a time when the red drift which came from the north was deposited; third, an eastward course at the time when the ice from the northwest advanced over land that had been vacated by the ice which deposited the red drift.

\section{GLACIAL LAKE FEATURES}

Minnesota contains parts of the beds of two large glacial lakes: Lake Duluth, which occupied the western part of the Superior basin, and Lake Agassiz which occupied the Red River basin. Lake Duluth covered a narrow strip along the shore of Lake Superior and extended a few miles beyond the west end of Lake Superior into eastern Carlton County, Minnesota. Its highest stages were 500 to 700 feet above the present surface of Lake Superior, there being an increasing height toward the northeast corner of the state. Lake Agassiz extended as far south as Lake Traverse, and thence it discharged past Brown Valley to the Minnesota. Its border is only from 20 to 30 miles east from the North Dakota-Minnesota line from Lake Traverse northward to Polk County. About 20 miles east-southeast of Crookston it makes an abrupt eastward turn and contintes eastward past the south side of Red Lake and on across Koochiching County into St. Louis County as far as the valley of Little Fork River. It then turns northward and enters Canada from northeastern St. Louis County. There were several islands in it in northern St. Louis County.

Preceding the development of the large glacial Lake Agassiz there was a temporary ponding of waters in front of the ice in Koochiching, Itasca, and St. Louis counties at a level higher than that of Lake Agassiz, and a discharge of the waters southward across the Mesabi Iron Range into the St. Louis basin along the course of the Embarrass River. With the melting back of the ice border this lake became merged with Lake Agassiz, and its waters then discharged into the Minnesota valley.

In the Crow Wing drainage basin a glacial lake, Lake Wadena, covering much of Wadena County, and parts of Hubbard, Cass, Morrison, and Todd counties, was held up by the Patrician ice sheet, which covered the lower course of Crow Wing River below Pillager. Its outlet was 
southward from Long Prairie to the Sauk River drainage. Outwash plains near Pillager terminate abruptly at the edge of this lake at an altitude of about I,300 feet, or nearly I 50 feet above the adjacent part of the plain on Crow Wing River that was covered by the lake (see Pillager topographic map). This was the deepest part of the lake. In much of its area the waters were very shallow. This lake area was later encroached upon by the Keewatin ice sheet, so its shore lines are obliterated except along the eastern side. Its outlet has also been filled by gravel deposits from the Keewatin ice sheet for a few miles south from Long Prairie.

There were also two noteworthy temporary lakes in northeastern Minnesota which were not held up by ice barriers, but instead by land barriers along their outlets. When these were cut away the lakes became drained. One of these, named Lake Aitkin by Upham, occupied the plain bordering the Mississippi in Aitkin County and extended a short distance into eastern Crow IVing County. It was drained by the erosion of the Mississippi valley at its lower end just above Brainerd. The other lake, named Lake Upham by Winchell, occupied a considerable part of the St. Louis basin in western St. Louis County. It was drained by the erosion of the St. Louis valley below Floodwood.

Prominent features of the two great glacial lakes, Lake Agassiz and Lake Duluth, are the beaches or ridges of sand and gravel washed up along their shores. The shores of Lake Agassiz stand high and dry above the flat parts of the lake bed between or below them and form excellent lines for highways. For this reason much of the pioneer settlement and travel was along these ridges. They generally stand from 5 to to feet above the bordering plains and occasionally from $I 5$ to 20 feet. On the inner or lakeward side they are generally more prominent than on the outer or landward side. This is due in part to the original slope toward the center of the lake, but there is also a tendency for a lake to eat back into the bordering land and throw its coarser material up on the edge of the plain outside; at the same time the fine material is carried in suspension from the shore into the deeper water.

The levels of these glacial lakes were lowered from time to time, partly by the cutting-down of the outlets and partly by an uplift of this region which caused the water to fall away where the land rose. There was also a change of outlet in Lake Agassiz from the southern end to the northern and in Lake Duluth from the southward outlet into the St. Croix River to an eastward outlet into the Lake Huron basin. As a result shore lines were formed at various levels on the slopes of the old lake beds. Because of the gradual lowering of the water level the greater part of the beds of these glacial lakes has at some time been 
subjected to wave action. This has produced a widespread pebbly coating which is a concentrate from the washing of the surface of the bowlder clay and the carrying-away of its finer material. Where the bowlder clay was sandy, the sand as well as stones remain, but where it was clayey there is often a clear bed of pebbles a few inches in depth covering the clayey till subsoil. The deep part of Lake Agassiz along the borders of Red River received nearly all the fine sediment which was washed out from the till at higher levels. This forms the bulk of the rich black clay and clay loam of the Red River basin. At its eastern border, fiftcen to twenty-five miles from Red River, there is a transition to sand. This is succeeded within two to five miles east by stony sandy deposits which seem to be a glacial material worked over by the lake.

\section{GENERAL SOIL CONDITIONS}

Soil is composed of materials derived from the subsoil and mixed with organic matter. Subsoil is the weathered and disintegrated top of the underlying geological formation. For its qualities and composition the soil of a given region therefore depends quite closely upon the nature of the geological formations there exposed. In Minnesota the land mantle of glacial and lake deposits affords a well-mixed and rich supply of materials suited for soil-making. This is particularly true where it consists of till or bowlder clay in which all classes of material are loosely but thoroughly mixed. This contrasts with soils in which there is too much uniformity and which, when of water-washed sand or gravel, are often deficient in fine material. On the other hand, the loess and the lake silts, though of somewhat uniform texture, make rich soils because of the variety of finely divided minerals which they contain.

The soil and its productiveness depend largely upon the drainage conditions. A soil of clay or clay loam over gravel or loose sand suffers in time of deficient rainfall, while in wet seasons a soil resting upon heavy clay may be drowned out unless surface drainage is perfectly adjusted. For this reason the geologic formation underlying a soil is of great importance. Soil underlaid by limestone, by loess, or by a till consisting of a light clay, or a heavy loam will stand great variation in rainfall and still be highly productive. In some parts of the state the surface drainage is naturally well developed, while in other parts it needs to be greatly supplemented by tile draining or surface ditching.

In the Driftless Area the drainage on the uplands is everywhere complete, for nearly every acre slopes toward some drainage line. In the old drift also there are few undrained areas and tiling or surface ditching is seldom necessary. In the young drift there are many basins, and undrained depressions and drainage lines are not well distributed over the 
surface. Except, therefore, where the material is loose enough for the rainfall to be absorbed completely the young drift areas need considerable ditching and tiling. In the bed of Lake Agassiz, although basins and depressions are rare, there are wide areas where the surface is very flat and extensive and systematic tiling or ditching is required to keep the land from being flooded.

\section{VEGETATION}

The condition of the soil depends to some degree upon the character of the vegetation which has covered it. In prairie districts there is a more uniform exposure to weathering agencies than in forested districts and consequently a more uniform soil is developed on a given deposit. On the whole, leaching of lime seems to be less rapid on prairies than in forests so that in the newer drift limestones are often present at the surface in prairies, but in the forested areas limestones are usually dissolved out to a depth of some inches and often to some feet from the surface. On the older drift the limestone is generally removed to a depth of several feet both in prairie and forest, but the leaching is perceptibly deeper in the forested areas. The rate of erosion and removal of soil is more uniform in prairie than in forested tracts. It takes more force to dislodge the trees than the grassy vegetation on hillside slopes, and erosion in the forests is likely to become concentrated in occasional gullies, whereas on prairies there are many small channels developed on every hillside which serve to break it down rapidly. On the whole, therefore, erosion is greater but leaching is less in prairie than in forested areas.

The forests occur only on protected slopes in much of southern Minnesota and are absent from such slopes in much of the western part of the state (Figure 3 ). In the central and northeastern parts they cover plains or uplands as well as valley slopes. The muskegs, which have a scanty forest growth, are developed chiefly in the northern half of the state and chiefly within the forested area.

\section{WEATHERING}

There are parts of the newer drift in which fresh material is close to the surface so that they can scarcely be said to have a subsoil different from the drift sheet as a whole. There are also places on valley slopes in the older drift where unweathered material is close to the surface, because erosion keeps pace with the weathering of the drift. At most places, however, the older drift has a mantle of weathered material several feet in thickness, while that of the younger drift is only one or two feet thick. In this the feldspar and other minerals are disintegrated and made ready for plant food. 


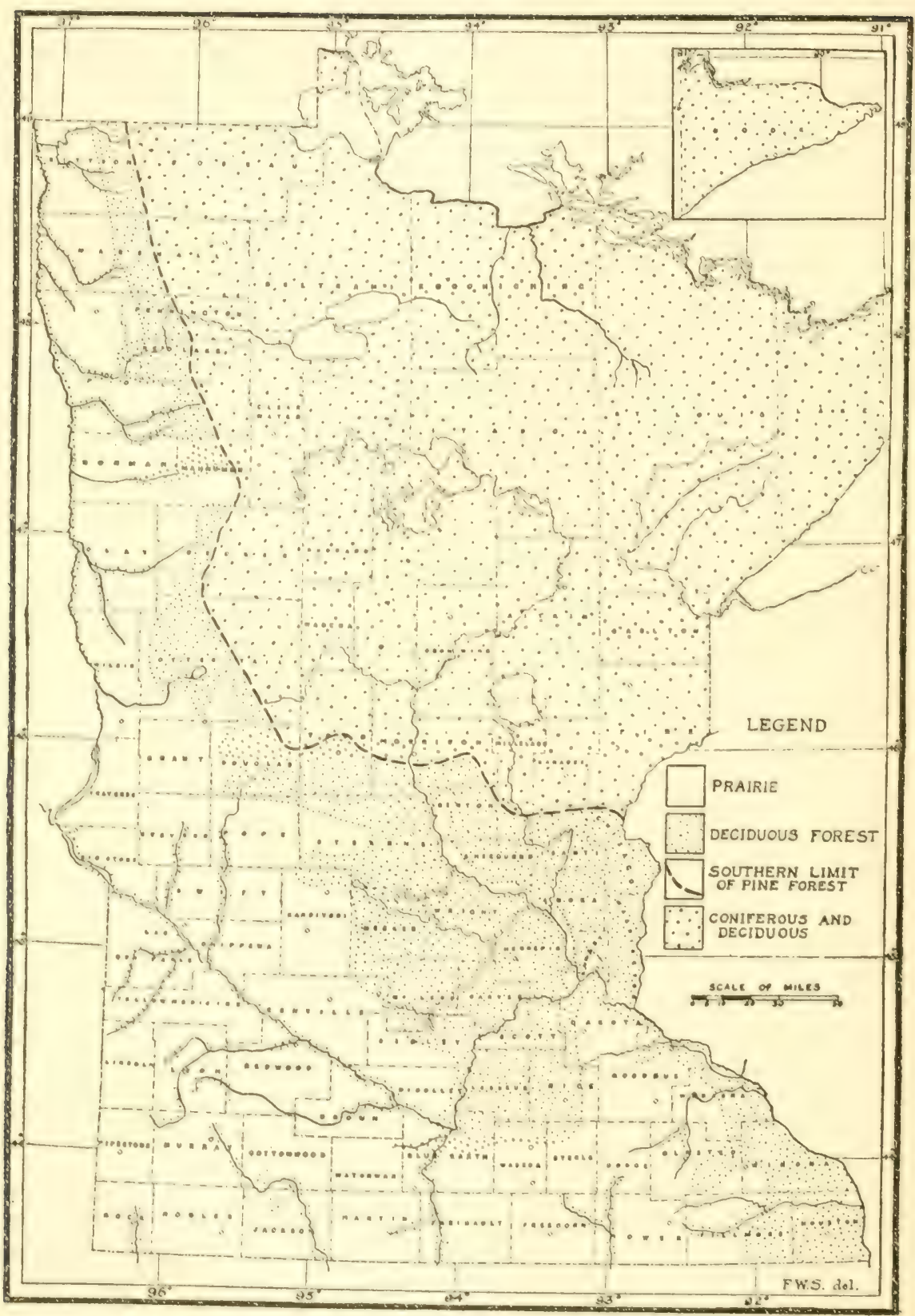

FiguRE 3. MAP OF MINNESOTA SHOWING DISTRIBUTION OF FOREST AND PRAIRIE. (AFTER MAP BY WARREN UPHAM AND BY FREDERIC K. BUTTERS) 
Weathering in the loess-covered areas is moderately deep, as it is in the older drift. The entire deposit of loess, however, is of fine texture and is found to be very fertile from top to bottom.

LIME

While most of the soils of the northwestern part of the state seem abundantly supplied with line, it is probable that sone of the more sandy ones would give a sufficiently greater yield of certain crops to make it profitable to purchase some form of lime if this could be obtained at a low price. Usually when a soil needs lime, it is advisable to apply one ton or more of ground limestone or marl per acre. If this has to be shipped any considerable distance, the ireight drares may sreatly execed the cost of the material on board of the cars at the point of shipment. For this reason it is important to locate a supply as near as possible to the place where it is to be used.

Lime occurs abundantly in two forms in Minnesota: as bog-lime or marl, and as linestonc. The mat is meonsoliclated and casily pulverized. It needs no crushing or grinding. Limestone is consolidated and must be crushed or ground for use on fields.

Marl is found in Minnesota in many lakes and under some bogs that have been lakes. It is of most frequent occurrence in the central and north central part of the state. It lies always in low wet ground and can be found, as a rule, only by boring or ditching. It is a soft, whitc or gray, chalky material. Since it needs no crushing or grinding, the cost of the marl is in the finding, ditching and draining, or drying of it. Deposits from I to Io feet in thickness and covering from I to Ioo acres are known to be of common occurrence.

Limestone formations onterop in the blulfs along the Mississippi and its tributaries in southeastern Minnesota. The formations lie horizontally and are of wide extent, or practically continuous for many miles. Limestone formations 100 feet or more thick extend along the valleys from the sontheastern corner of the state to Stillwater, Minneapolis, Mankato, Austin, and intermediate points. An inexhaustible supply of limestone is easily found in outcrops that are high, so that quarrying, crushing, and loading can all be done in a down-hill direction, the cost of production being thereby lessened.

\section{EFFECT OF FIRES}

There are large areas in Minnesota which have been swept by forest fires, and these fires have destroyed much of the accumulated leaf mold. In sandy areas the destruction of the leaf mold may have reduced somewhat the productiveness of the land, for the leaf mold acts as a mulch to prevent the drying out of the soil. But in clayey areas there seems to 
have been very little reduction of the fertility. The leaf mold in such places, however, when turned under has a beneficial effect in loosening the stiff clay. A large area of clay land in the Little Fork drainage basin in St. Louis and southeastern Koochiching counties was burned over some fifty or more years ago, according to statements of the Indians, and the leaf mold was almost completely destroyed. A heavy growth of poplar has sprung up on the drier parts instead of the mixed hardwood that had occupied the land, while the wet areas have a fresh stand of spruce. This district is being rapidly cleared and is producing exceptionally good crops. The forest fire near Hinckley in Pine County, which occurred about twenty-five years ago, swept over an area chiefly of till much of which is loose-textured. This had a similar effect in changing the forest from mixed hardwood and pine to poplar. This area is now one of marked agricultural fertility adapted to a variety of crops. The principal damage by fire in this state, both past and prospective, seems to be in the destruction of peat in the bogs. In such cases there is not only the loss of a valuable fuel, but the land is left in a rough state ill-suited for cultivation. 


\title{
CLIMATIC CONDITIONS OF MINNESOTA
}

\author{
By U. G. Purssell \\ Director of the Minnesota Section of the United States Weather Burean
}

\section{INTRODUCTION}

The agriculture of any region is controlled by its climate. In some parts of the world temperature is the main factor in determining the limits of growth of certain kinds of crops; in others it is rainfall, and in still others it is the amount of sunshine. All of these factors are important in influencing the crop yield even in districts where the general climatic conditions are satisfactory for the growth of plants. In Minnesota these elements are so favorable that a majority of the crops common to the temperate zone may be successfully grown, and a failure of all the important crops is very rare even over a small portion of the state.

Rainfall is an important factor for most crops in the state, because the proper amount of water in the soil at the critical period of development of the plant is necessary to produce a large crop. The length of the growing season also is important and probably no other factor in the study of climate from the standpoint of the agriculturist should be given more consideration. This is the key to an actual knowledge as to the possibilities of success or failure in the production of crops since in parts of the state crops are menaced by frost at some period of their growth, whereas sunshine and moisture seldom vary in Minnesota beyond safe limits.

The factors which determine the climate of any area are the relative distribution of land and water, the topography of the land surface, and the situation of the area in question with relation to the general movement of the cyclones and anti-cyclones.

The position of Minnesota at the center of North America gives it a climate that is largely continental. In continental climates the temperature extremes are greater and the humidity and rainfall generally less than at places near large bodies of water, such as border on the Atlantic, Pacific, and Gulf coasts of the United States. The effect of winds from great bodies of water is to equalize temperatures of lands near by and to lengthen materially the crop-growing season. This is particularly true of the country in the vicinity of Lake Superior, where the infuence of that great inland sea in modifying the cold anti-cyclones 
gives to that section a more equable climate than would otherwise obtain in that portion of the state. The summer temperatures are likewise modified and people from long distances inland in steadily increasing numbers are establishing summer homes about the lake, to which they are attracted during the hot summer months. There are more than 7,000 small lakes scattered throughout the state and these have a material local infiuence in modifying the heat of summer and give comfort to thousands of residents on their shores.

Monthly and annual reports of temperature, rainfall, snowfall, etc., have been published for a large number of regular and coöperative stations in Minnesota since I 895 . Recently three special section reports have been issued by the United States Weather Burcau giving monthly and annual precipitation totals for all points in the state with a record of ten years or over, together with average temperatures and other data. In these reports the more important facts from all portions of the state are tabulated and the comparative climatic conditions of the different sections graphically shown.

\section{GENERAL CLIMATIC CONDITIONS}

Minnesota is in the path of a large proportion of the low-pressure areas which move across the United States from west to east. These areas move at an average speed of 600 miles in twenty-four hours and are preceded by southerly winds and higher temperature and followed by northerly winds and lower temperature. They are usually accompanied by clondy weather and precipitation; each storm causing an average of from one to two rainy days as it crosses the state.

As there is an average of almost two of these storms each week with fair weather periods between, it follows that the changes in weather conditions are rather rapid. One or two days of stormy weather preceded by fair weather and followed by clearing and lower temperatures to be repeated in turn, make up the usual routine for the week. However, Minnesota is so far from the coast that damaging ocean storms lose much of their severity before reaching its borders.

The northwestern cold waves pass across the state and send their health-giving winds into all parts, and yet they are frequently not so severe as they are in some of the plains states in the same latitude or even farther south.

Temperature.-The average annual temperature of Minnesota for the period I895 to I9I 3 inclusive, is $41.7^{\circ}$, as shown in Table I and graphically by Figure 4 . The highest annual mean temperature, $43.9^{\circ}$, occurred in 1900 , and the lowest, $39.9^{\circ}$, in 1912. The departure of the average temperature of any year from the normal may readily be deter- 


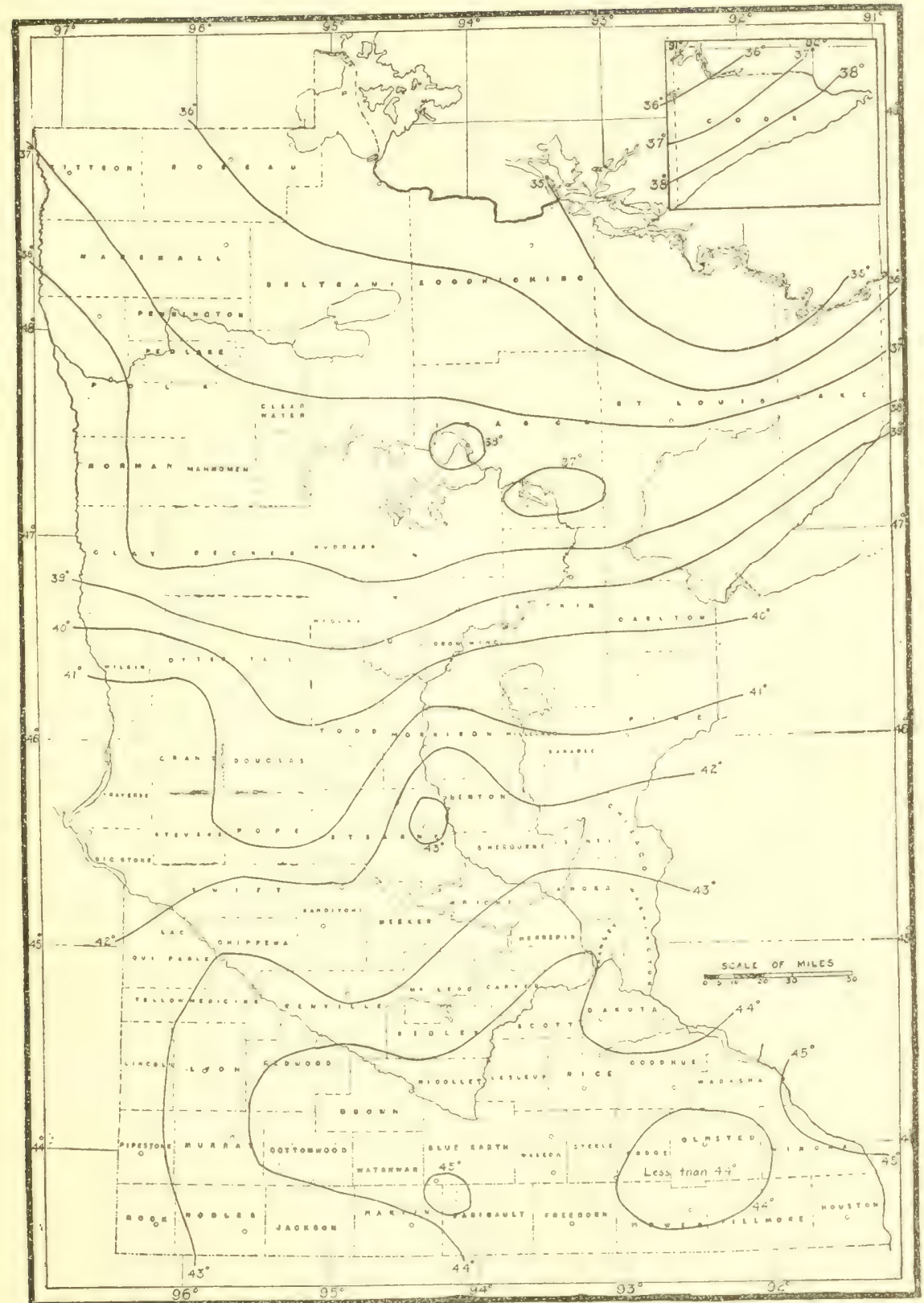

FIGURE 4. MAP SHOWING MEAN ANNUAL TEMPERATURES OF MINNESOTA (DEGREES FAHRENHEIT) 
mined by comparing the vearly average with the mean at the foot of the column.

Table I. Monthly and Annual Mean Temperature for Minnesota (Degrees Fahrenheit)

\begin{tabular}{|c|c|c|c|c|c|c|c|c|c|c|c|c|c|c|}
\hline & & Jan. & Feb. & Mar. & April & May & June & July & Aug. & Sept. & Oct. & Nov. & Dec. & Year \\
\hline & $\ldots \ldots \ldots$ & . & & & 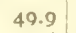 & 56.9 & 04.0 & 67.8 & $07 \cdot 4$ & 61.5 & 41.4 & 27.0 & 10.3 & \\
\hline & $\ldots \ldots$ & 12.3 & & & & 60.9 & & 69.9 & 67.9 & 3 & 42.4 & .0 & 20.3 & 41.6 \\
\hline & $\ldots \ldots$ & 7.2 & 15.3 & & 3.7 & 55 & 5 & & .2 & & 50.0 & 6.6 & 12.3 & 41.2 \\
\hline & $\ldots$ & 18.3 & 16.4 & & 4 & 5 & .0 & 8 & 5.9 & 6 & 42.9 & 26.6 & 11.9 & 42.2 \\
\hline & $\ldots \ldots$ & 9.9 & $4 \cdot 5$ & & $4.6-1-3) \cdot 3$ & 55 & & & 69.1 & 56.4 & 49.0 & 39.6 & 17.9 & 41.3 \\
\hline & $\ldots \ldots \ldots$ & 18.4 & 5.2 & & 9. & & & 68 & .3 & 2 & 55.1 & 4 & I 8.6 & 43.9 \\
\hline 1901 & $\ldots \ldots \ldots$ & 1.3 .2 & Io.c & & 6.7 & 58 & 5 & 74.7 & 8 & $57 \cdot \overline{3}$ & 49.2 & 28.8 & 13.0 & 42.8 \\
\hline 1902 & $\ldots \ldots$ & I 5.9 & I.5.5 & 3 & 4 & 57 & & 69.7 & .2 & 2 & 47.1 & 33.3 & 12.6 & 42.6 \\
\hline 1903 & $\cdots \cdots \cdots$ & I I. 3 & 10.6 & 2 & 4 & 55 & 3 & 67.2 & 6 & 55.5 & 46.1 & 27.3 & 9.8 & 40.3 \\
\hline 1904 & $\cdots \cdots \cdots$ & 4. & 2.3 & 2 & 38.8 & & 2 & 66.0 & 9 & 4 & 47.4 & 36.7 & 16.7 & 40.1 \\
\hline 1905 & $\ldots \ldots \ldots$ & 5.6 & 8.9 & 3. & .0 & 5 & 0 & $67 \cdot 3$ & 9 & & 43.5 & 33.1 & 20.6 & 41.5 \\
\hline 9006 & $\ldots \ldots \ldots$ & 17.0 & 13.8 & 28 & 4 & 5 & 7 & 68.3 & 7 & 63.3 & 45.7 & 30.7 & 15.9 & 42.0 \\
\hline 1907 & $\cdots \cdots \cdots$ & 3.8 & 148 & 28.7 & 34 & & 3 & 2 & 1 & 9 & 45.4 & 31.7 & $2 I .3$ & 40.1 \\
\hline 908 & $\cdots \ldots \ldots$ & 16.4 & 17.9 & 26 & 45 & & & 69.4 & 5 & & 47.0 & 33.8 & 17.5 & 43.4 \\
\hline 1909 & $\cdots \cdots \cdots$ & 10.5 & 13.7 & 26.1 & 35.8 & & 0 & 69.2 & 9 & 58.7 & 44.7 & 33.8 & 10.0 & 41.0 \\
\hline 910 & $\cdots \ldots \ldots$ & 11.8 & 7.5 & 41.7 & 48.0 & & 6 & 70.6 & 8 & & 50.8 & $25 \cdot 3$ & 14.7 & 42.8 \\
\hline I9II & $\cdots \cdots$ & 5.4 & 16.6 & 32.7 & 42.7 & & 7 & & 64.0 & 56.7 & 43.4 & 20.2 & 19.4 & 4 I, 6 \\
\hline 1912 & $\cdots \ldots \ldots$ & -0.7 & $\begin{array}{r}10 . h \\
8.6\end{array}$ & I 9.8 & $45 \cdot 5$ & & & 5 & 9 & 57.2 & 47.5 & 33.9 & 20.0 & 39.9 \\
\hline 1913 & $\cdots \cdots \cdots$ & 7.2 & 8.6 & 20.4 & 40.4 & 52 & & 07.3 & & & 42.7 & 36.9 & 20.1 & 42.0 \\
\hline \multirow[t]{2}{*}{1914} & $\cdots \ldots$ & 10.9 & 2.8 & 26.6 & $4 \mathrm{I}, 2$ & 57. & & 72.4 & $I$ & 60.0 & 52.6 & 33.0 & 9.0 & 41.8 \\
\hline & Mean.... & 10.5 & 11.2 & 26.5 & 43.8 & 55.3 & 64.7 & 69.3 & 67.1 & 58.8 & 46.5 & 30.1 & 16.7 & 41.7 \\
\hline
\end{tabular}

The coldest month is January, which has a mean temperature of $10.5^{\circ}$, although the average for February is only $0.7^{\circ}$ higher. In a great many instances February has averaged colder than the preceding January. This condition occurred in the seven successive years from 1898 to 1904 inclusive. Average January temperatures are plotted on Figure 5.

July is the warmest month, with an average temperature of $69.3^{\circ}$, although in a few years the mean temperature for June or for August is higher than for July of the same year. Average July temperatures are plotted on Figure 6.

The highest summer mean, $70.0^{\circ}$, occurred in 1900 and I90I (Table II). The coldest summer was that of I903, with an average of $64.4^{\circ}$.

The warmest crop-growing season (April to September inclusive) of the eighteen years under discussion was in 1900, when the average was $62.9^{\circ}$, and the coldest was in 1907 , with an average of $55.6^{\circ}$.

The warmest winter (December to February inclusive) was in 1907-8, when the mean temperature was $18.5^{\circ}$. The coldest was in $1903-4$, with a mean temperature of $5 \cdot 5^{\circ}$. Table II shows also the warmest and coldest spring and autumn.

In Figures 7 and 8 are shown the highest and lowest temperatures ever recorded in the various counties where records have been kept. From these figures it can readily be seen that the extreme range of temperature is from $110^{\circ}$ in Kandiyohi County and Milan, to $-59^{\circ}$ at Leech Lake Dam and Pokegama Falls. Temperatures above $100^{\circ}$ have been recorded in all counties except those about the headwaters of the Missis- 


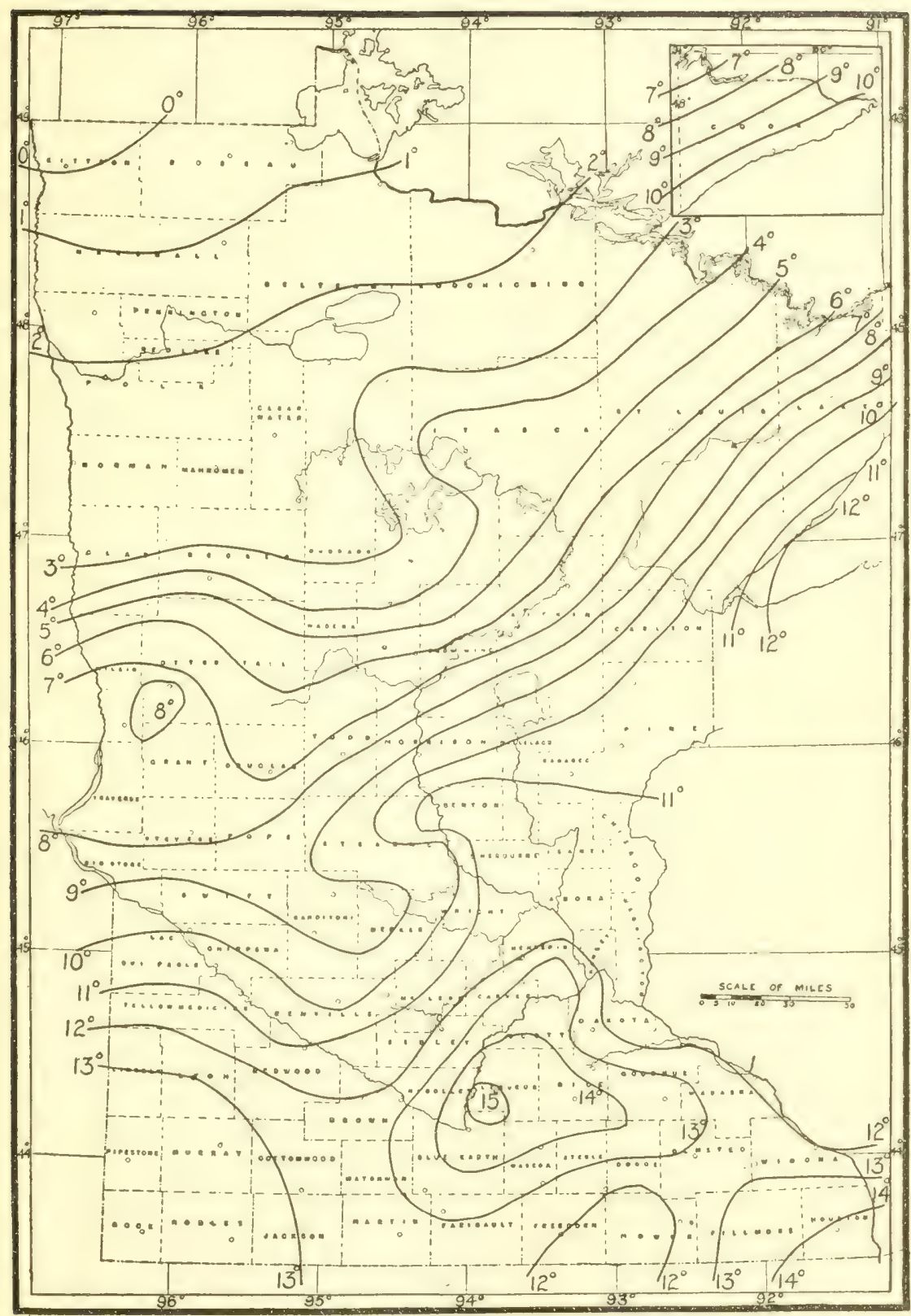

FIGURE 5. MAP SHOWING MEAN TEMPERATURES OF MINNESOTA FOR JANUARY (DEGREES FAHRENHEIT) 


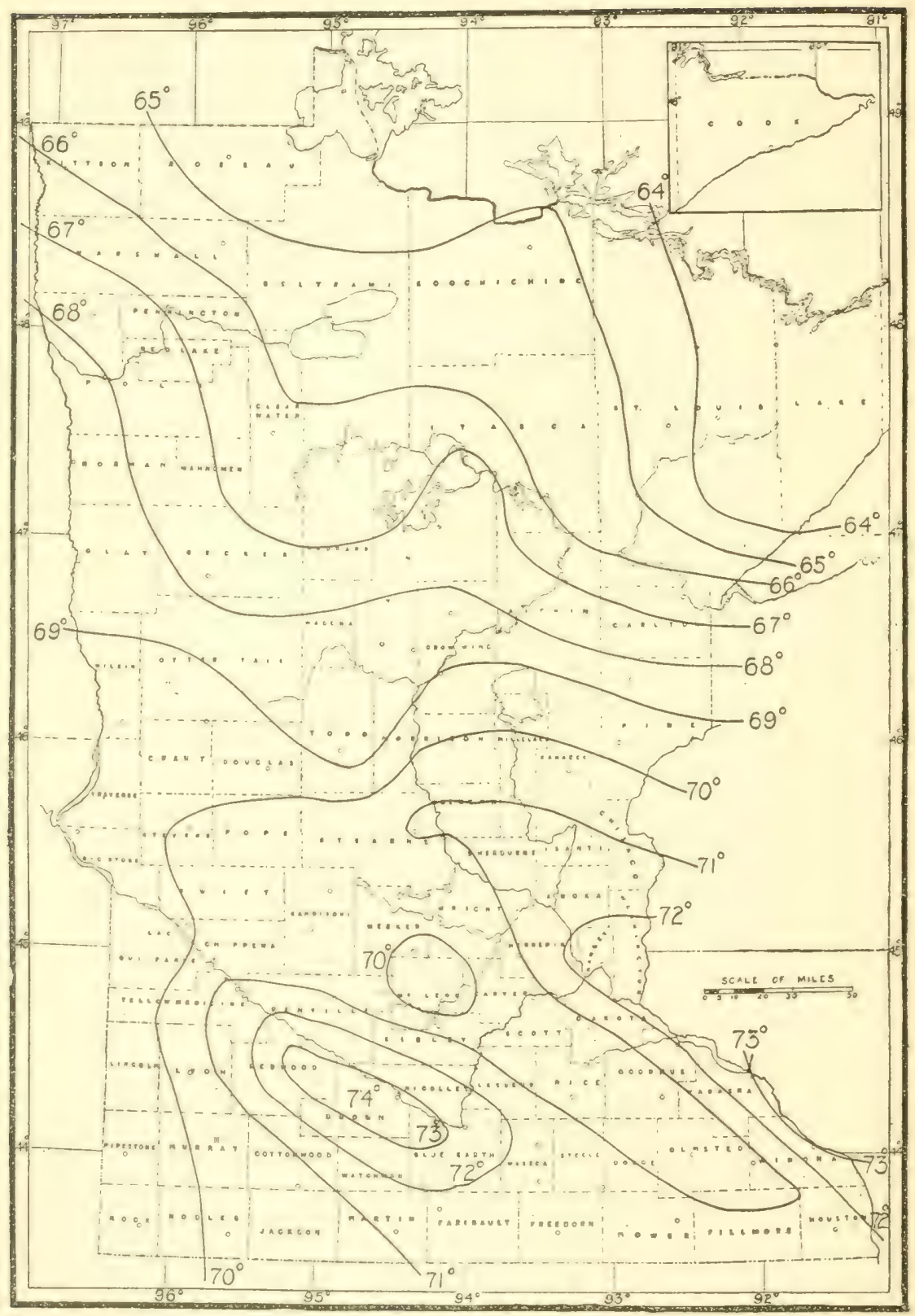

FIGURE 6. MAP SHOWING MEAN TEMPERATURES OF MINNESOTA FOR JULY (DEGREES FAHRENHETT) 


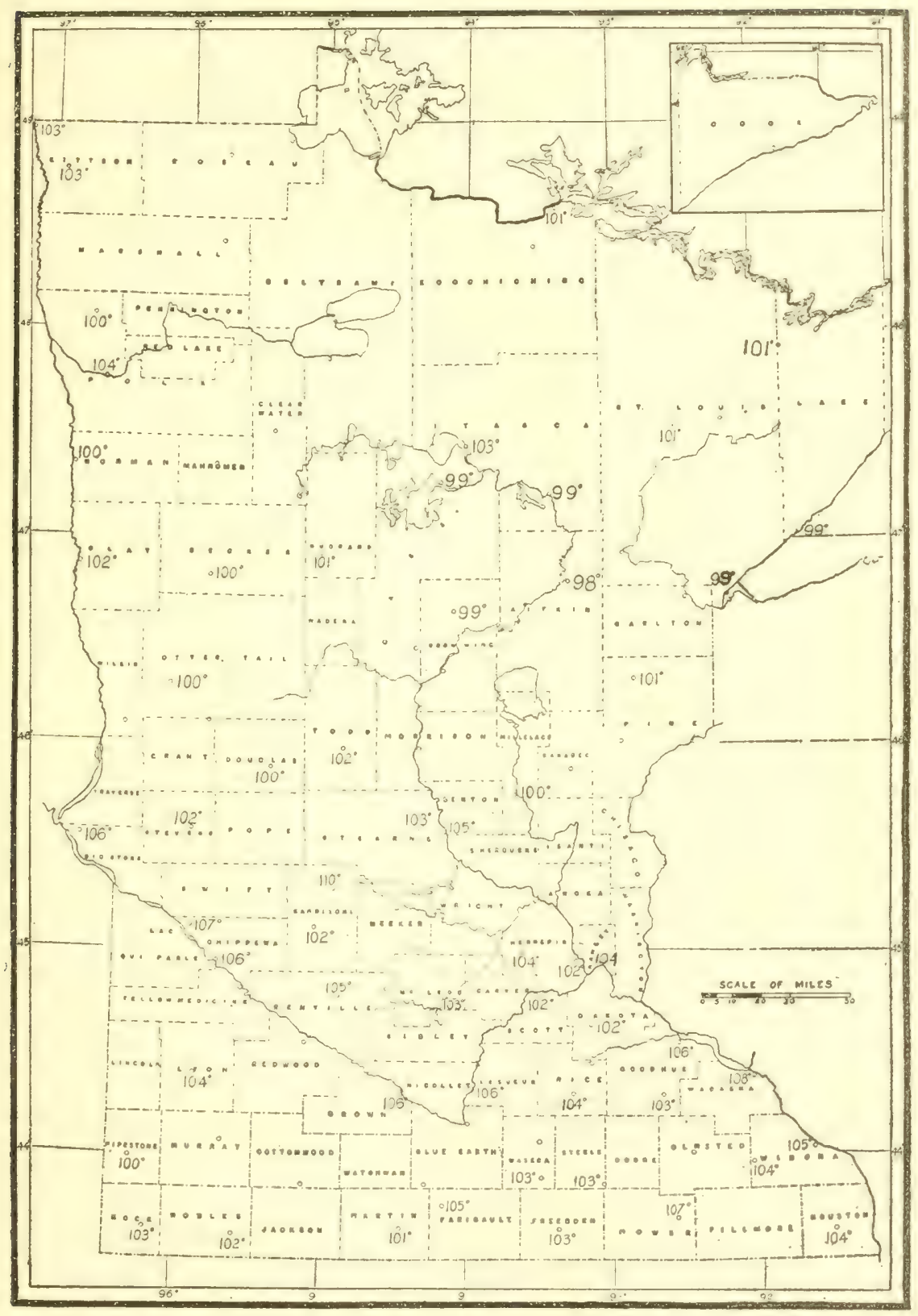

FIGURE 7. LSAP SHOWING HIGHEST KNOWN TEMPERATURES IN MINNESOTA (DEGREES FAHRENHEIT) 


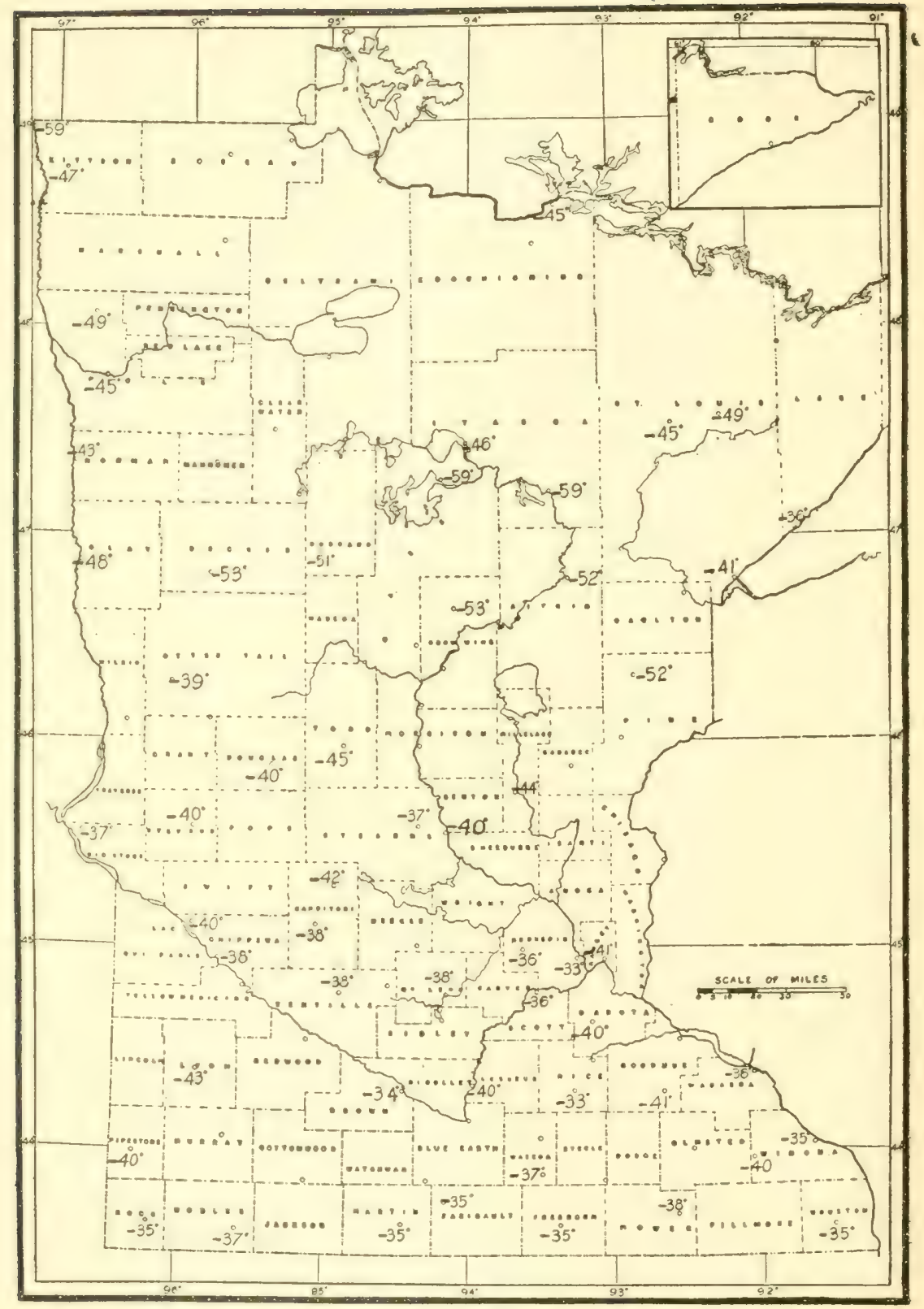

FIGURE 8. MAP SHOWING LOWEST KNOWN TEMPERATURES IN MINNESOTA (DEGREES FAHRENHEIT) 
sippi River, and in the country immediately bordering on Ialie Superior. Temperatures of $-40^{\circ}$ have occurred in nearly all northern and central counties and in a few southern counties, but these great extremes do not occur frequently.

Table II. Seasonal Temperatures for Minnesota (Degrees Fahrenheit)

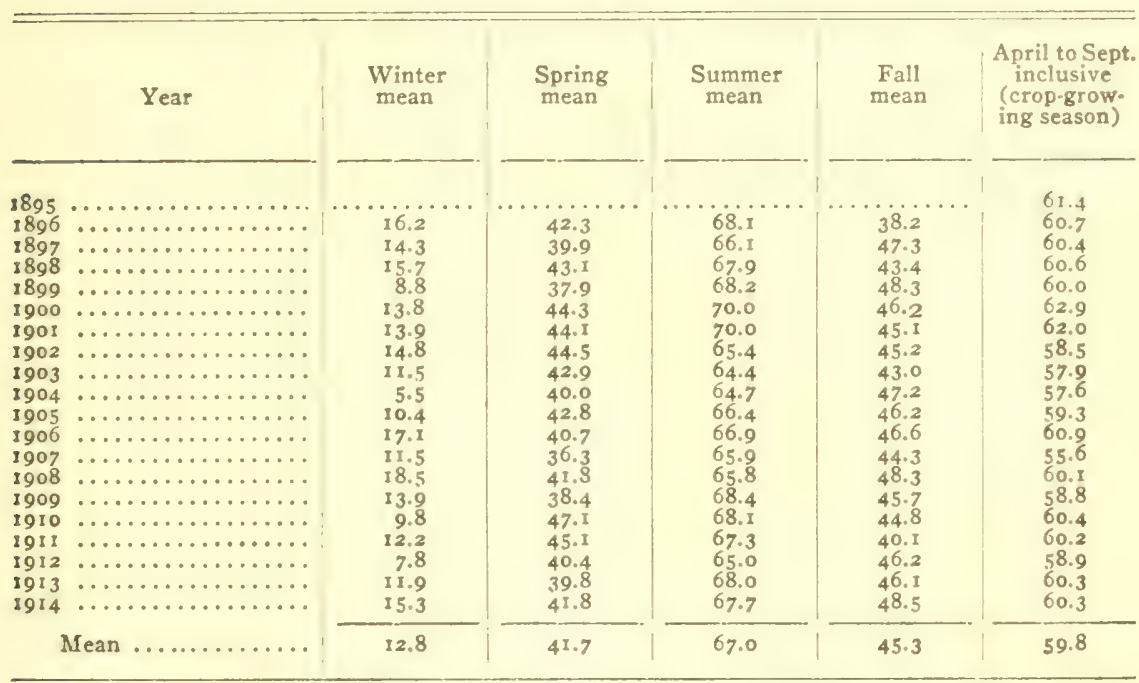

Frosts.-Although frosts have occurred in some portions of the state every month of the year, damaging temperatures are not to be expected during June, July, and August, and they are comparatively rare in the last half of May and the first half of September. Records of ten or more years are available from a large number of places in the state, of which charts have been constructed showing the average date of the last killing frost in spring and the first one in autumn. Using these dates as boundaries, we can mark the average beginning and ending of crop growth and determine the average length of the growing season. All of this information is graphically shown in Figures 9, I0, and II. By reference to Figure I I the influence of Lake Superior in lengthening the cropgrowing season in its vicinity may be seen; while in the same latitude in the highlands of Hubbard, Becker, eastern Mahnomen, and Clearwater counties the season is twenty to thirty days shorter. The longest season, I60 days, obtains along the Mississippi River from Hennepin County to the southeastern corner of the state, and the shortest, Ioo days or less, is in the region of the Mesabi and Vermilion Iron ranges. 


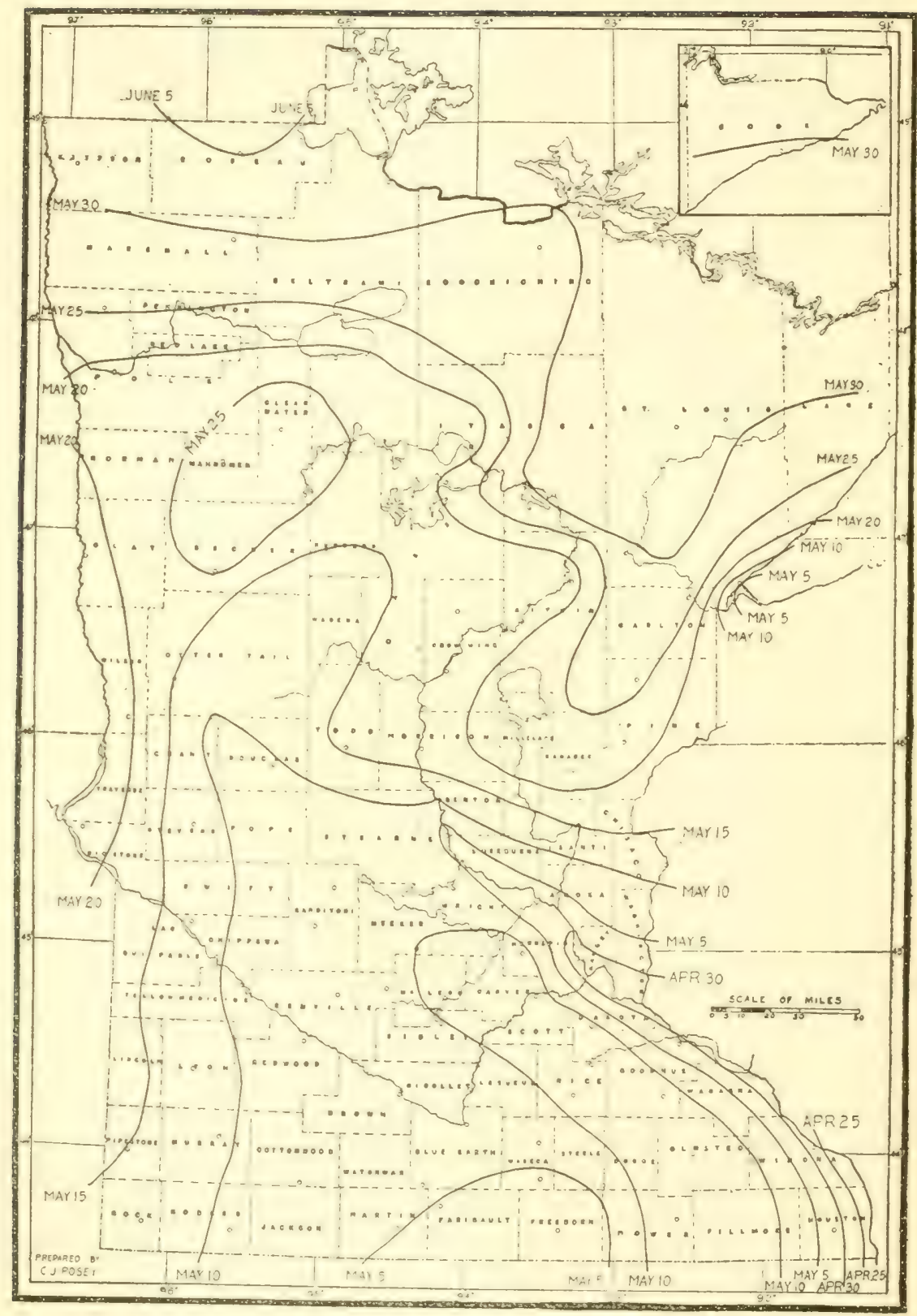

FIGURE 9. MAP SHOWING AVERAGE DATE OF THE LAST KILLING FROST IN SPRING IN MINNESOTA 


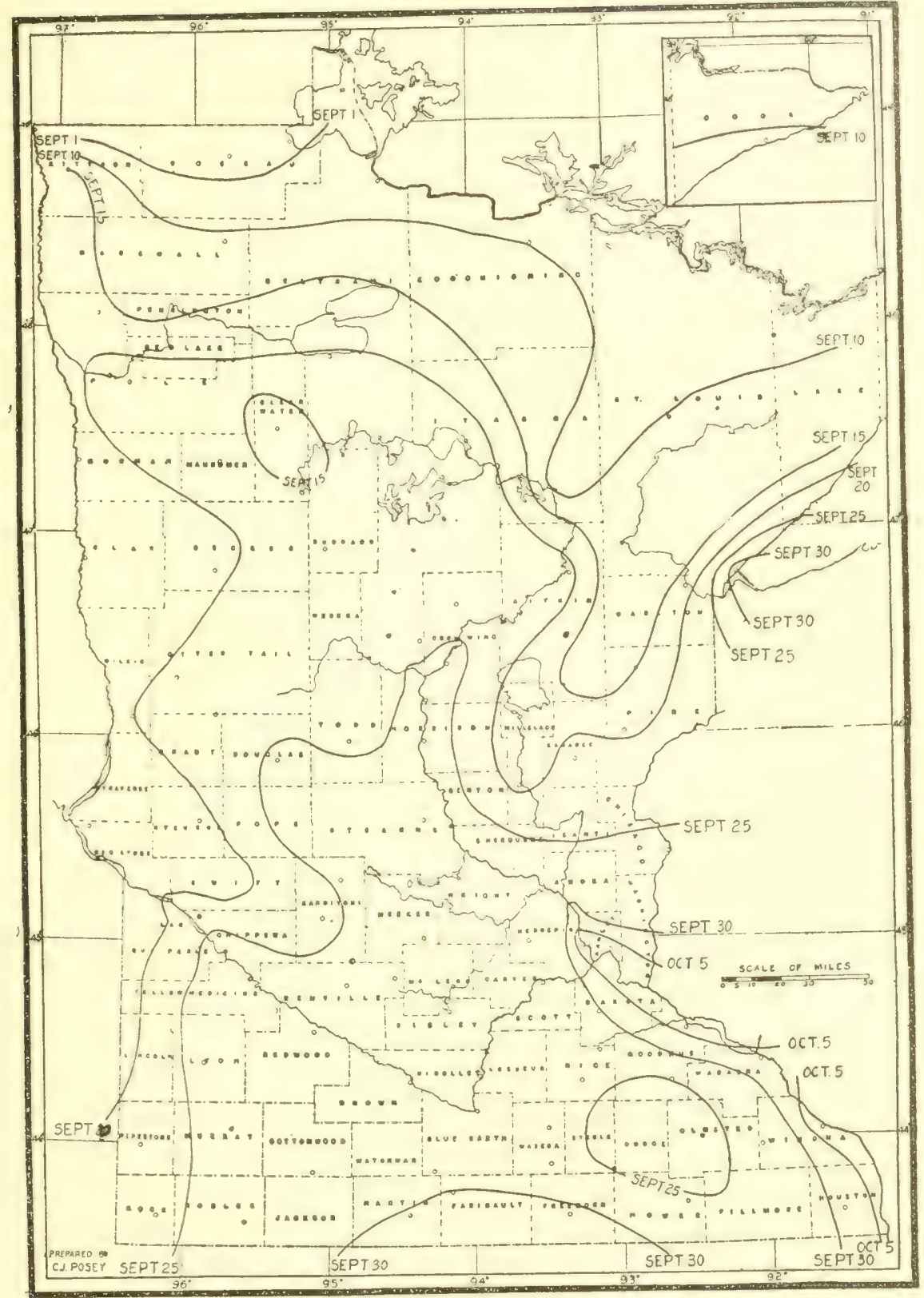

FIGURE IO, MAP SHOWING AVERAGE DATE OF FIRST KILLING FROST IN AUTUMN IN MINNESOTA 


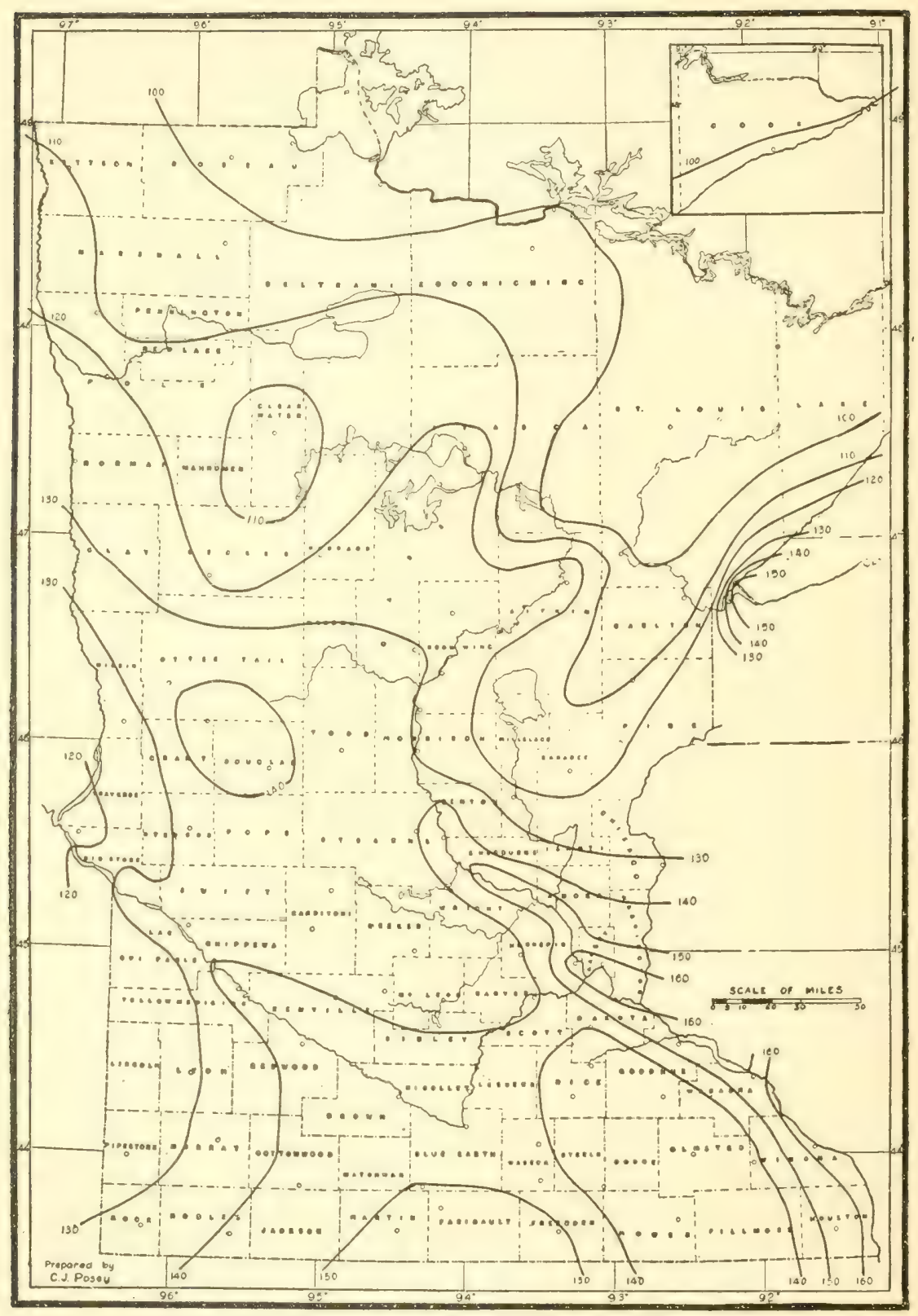

FIGURE II. MAP SHOWING NUMBER OF DAYS OF THE AVERAGE CROP-GROWING SEASON IN MINNESOTA 


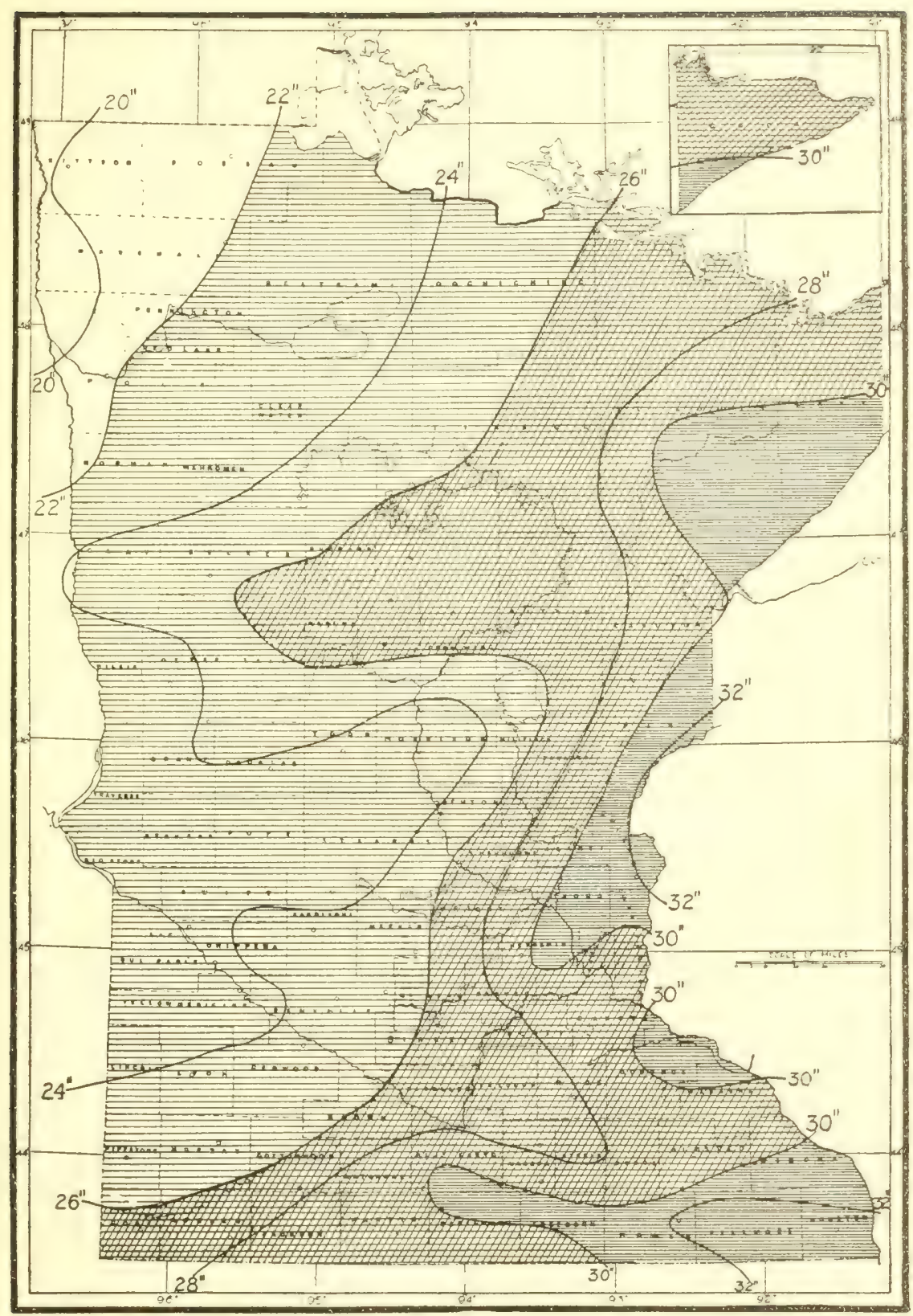

FIGURE 12. MAP SHOWING THE AVERAGE ANNUAL PRECIPITATION FOR MINNESOTA 
Table III. Average Monthly and Annual Precipitation for Minnesola (in Inches)

\begin{tabular}{|c|c|c|c|c|c|c|c|c|c|c|c|c|c|c|c|}
\hline & & Jan. & Feb. & Mar. & Apr. & May & June & July & Aug. & Sept. & Oct. & Nov. & Dec. & Year & $\begin{array}{l}\text { Total } \\
\text { April to } \\
\text { Sept. } \\
\text { incl. }\end{array}$ \\
\hline 895 & $\cdots$ & & & & 1.68 & 3.30 & $4 \cdot 37$ & 3.25 & 2.27 & 3.93 & 0.25 & 1.22 & 0.28 & 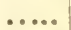 & 18.80 \\
\hline & $\ldots \ldots \ldots$ & 70 & .39 & 97 & 5.91 & 5.03 & 4.07 & 3.88 & 2.28 & 3.49 & 2.95 & 2.69 & 0.61 & 32.04 & 21.65 \\
\hline ×897 & $\ldots \ldots \ldots$ & 1.77 & 1.21 & 2.07 & 1.55 & 1.38 & 5.40 & 6.62 & 2.54 & 1.89 & 1.55 & 0.53 & 0.38 & 27.33 & 19.38 \\
\hline I 898 & $\ldots \ldots \ldots$ & 0.16 & 1.02 & 1.21 & $x .64$ & 3.26 & 3.93 & 2.94 & 3.22 & 1.52 & 3.83 & 1.02 & 0.18 & 24.21 & 16.51 \\
\hline 1899 & $\ldots \ldots \ldots$ & 0.60 & 0.78 & I. 58 & 1.49 & 4.46 & 6.36 & 4 & 5.35 & 1.47 & 3.22 & 0.63 & 0.95 & 30.14 & 31.97 \\
\hline 1900 & $\ldots \ldots \ldots$ & 0.48 & 0.56 & 1.30 & $x, 47$ & 0.90 & 1.71 & 5.48 & 6.44 & 6.55 & 3.85 & 0.62 & 0.51 & 29.79 & 22.55 \\
\hline 1901 & $\ldots \ldots$ & 0.38 & 0.40 & $x .68$ & 1.73 & $1.4 \pi$ & 5.81 & $\mathbf{3 . 3 3}$ & 2.21 & $4 \cdot 34$ & 1.86 & 0.78 & 0.57 & 24.26 & 18.83 \\
\hline 1902 & $\ldots \ldots \ldots$ & 0.44 & 0.67 & 0.92 & 1.67 & 5.10 & 3.32 & 6 & 4.35 & 2.23 & 1.93 & $x .57$ & 1.79 & $29.4^{6}$ & 21.43 \\
\hline 1903 & $\ldots \ldots \ldots$ & 0.45 & 0.59 & 1.75 & 2.82 & 5.37 & $x .96$ & 5.11 & 4.65 & 5.63 & 3.33 & 0.35 & 0.84 & 32.85 & 25.54 \\
\hline 1904 & $\ldots \ldots \ldots$ & 0.39 & 0.62 & 1.51 & 1.72 & 2.43 & 4.26 & 3.96 & 2.77 & 3.14 & 3.50 & 0.14 & 0.82 & 29.65 & \\
\hline 1905 & $\ldots \ldots \ldots$ & 0.65 & 0.55 & .21 & $x .46$ & 5.54 & $6.4 \mathrm{I}$ & 4.12 & $4 \cdot 36$ & 3.45 & 2.53 & 2.64 & 0.15 & 33.10 & 25.34 \\
\hline 1906 & $\ldots \ldots \ldots$ & 1.15 & 0.27 & 1.20 & 1.72 & 5.58 & 4.55 & 2.93 & 4.66 & 3.73 & 2.28 & 1.82 & 0.91 & 31.66 & 23 \\
\hline 1907 & $\ldots \ldots \ldots$ & 1.17 & 0.58 & 0.94 & 3.01 & 2.14 & 4.31 & 3.57 & 4.11 & 3.48 & 1.31 & 0.57 & 0.57 & 24.03 & 18.62 \\
\hline 1908 & $\ldots \ldots \ldots$ & 0.31 & 1.11 & 47 & 2.55 & 6.31 & 6.35 & 3.21 & 2.07 & 2.41 & 1.91 & 1.18 & 0.79 & 29.49 & 32.90 \\
\hline 1909 & $\ldots \ldots \ldots$ & 1,32 & 1.31 & 0.54 & 1.89 & 3.36 & 3.53 & 3.84 & 5.54 & 3.16 & 1.56 & 3.68 & I. 54 & 29.37 & 20.32 \\
\hline 1910 & $\ldots \ldots \ldots$ & 0.83 & 0.45 & 0.27 & 8.54 & 1.58 & I.39 & 1.94 & 2.35 & 2.45 & 0.97 & 0.52 & 0.44 & 14.73 & 11.25 \\
\hline I gII & $\ldots \ldots \ldots$ & $0.8 \mathrm{I}$ & 0.88 & 0.63 & 1.88 & 3.48 & 3.79 & $3.6 x$ & 4.27 & 3.35 & 3.93 & 1.12 & I.35 & 39.10 & 20.38 \\
\hline 1913 & $\ldots \ldots \ldots$ & 0.40 & $0.2 \mathrm{I}$ & 0.45 & 2.04 & 4.13 & 8.66 & 4.30 & 3.97 & 3.03 & 0.97 & 0.36 & 0.93 & 22.45 & 19.13 \\
\hline 1913 & ...... & 0.33 & 0.44 & 1.27 & 1.87 & 3.53 & 3.08 & & 2.79 & 3.33 & 2.58 & 0.66 & 0.05 & 25.49 & 20.16 \\
\hline 1914 & $\ldots \ldots \ldots$ & $0.8 \mathrm{I}$ & 0.44 & 1.12 & 2.41 & 2.89 & 8.34 & 2.48 & 3.97 & 3.08 & 2.00 & $0.3^{8}$ & 0.44 & 28.06 & 23.77 \\
\hline \multicolumn{2}{|c|}{ Mean. } & 0.70 & 0.66 & 1.22 & 2.00 & 3.56 & 4.18 & 3.79 & 3.66 & 3.23 & 2.31 & 1.07 & $0.7 \mathrm{I}$ & 27.74 & 20.33 \\
\hline
\end{tabular}

Precipitation.-The annual average precipitation of the state as a whole for a period of nineteen years, 1896 to 1914 inclusive, is 27.74 inches, and for the crop season, April to September inclusive, for twenty years, I895 to I9I4, is 20.33 inches. The monthly, seasonal, and annual averages for this period are shown in Table III. The year with the greatest annual rainfall was 1905, when the total was 33.10 inches. The driest year was 1910 with 14.73 inches. In that year the rainfall during the crop-growing season was II.25 inches.

Table IV. Average Monthly and Annual Precipitation by Drainage Districts

\begin{tabular}{|c|c|c|c|c|c|c|c|c|c|c|c|c|c|}
\hline Watersheds & Jan. & Feb. & Mar. & April & May & June & July & 'Aug. & Sept. & Oct. & Nov. & Dec. & Year \\
\hline & In. & In. & In. & In. & In. & In & In. & In. & Ir & & In. & & \\
\hline $\begin{array}{l}\text { Lake Superior. . } \\
\text { Rainy River... }\end{array}$ & $\begin{array}{l}0.88 \\
0.94\end{array}$ & $\begin{array}{l}0.88 \\
0.94\end{array}$ & $\begin{array}{l}1.4 I \\
1.42\end{array}$ & $\begin{array}{l}2.05 \\
1.96\end{array}$ & $\begin{array}{l}3.50 \\
3.10\end{array}$ & $\begin{array}{l}4.19 \\
4.04\end{array}$ & $\begin{array}{l}4.21 \\
3.76\end{array}$ & $\begin{array}{l}3.73 \\
3.32\end{array}$ & $\begin{array}{l}4.18 \\
2.98\end{array}$ & $\begin{array}{l}2.80 \\
2.08\end{array}$ & $\begin{array}{l}1.45 \\
1.46\end{array}$ & $\begin{array}{l}1.13 \\
0.98\end{array}$ & $\begin{array}{l}30.40 \\
26.98\end{array}$ \\
\hline $\begin{array}{l}\text { Red River .... } \\
\text { Mississippi(above }\end{array}$ & 0.55 & 0.56 & 0.98 & 8.84 & 2.85 & 3.83 & 3.34 & 3.12 & 2.32 & 1.55 & 0.72 & 0.56 & 22.22 \\
\hline $\begin{array}{l}\text { St. Croix } \\
\text { St. Croix and } \mathrm{Mis} \text { - }\end{array}$ & 0.73 & 0.70 & 1.23 & 2.16 & 3.42 & 4.13 & $3.6 \mathrm{I}$ & 3.57 & 3.00 & 2.29 & $x .05$ & 0.73 & 26.63 \\
\hline $\begin{array}{l}\text { S1ssippi (below } \\
\text { St. Croix).... }\end{array}$ & 0.92 & 0.95 & 1.49 & 2.3 & 4.01 & 4.46 & 3.72 & 3.69 & $\sqrt{3}$ & 3.73 & 1.36 & I. I 3 & 30.57 \\
\hline $\begin{array}{l}\text { Minnesota River } \\
\text { Big Sioux and Des }\end{array}$ & 0.79 & 0.7 & 1.19 & 2.30 & 3.52 & 4.18 & 3.34 & 3.44 & 2.63 & 2.II & 1.02 & 0.79 & 26.04 \\
\hline Moines Rivers & 0.50 & 0.54 & 1.13 & 2.09 & 4.00 & 4.39 & 3.49 & 3.58 & 2.79 & 2.07 & 0.94 & 0.63 & 26.13 \\
\hline State....... & 0.76 & 0.75 & 1.25 & 2.18 & 3.53 & 4.19 & 3.55 & 3.50 & 3.02 & 2.24 & 1.09 & 0.84 & 26.90 \\
\hline
\end{tabular}

June is the wettest month with an average rainfall of 4.18 inches, and July is next with 3.79 inches. The lowest monthly rainfall is that of February with an average of 0.66 inch. The greatest rainfall in one month for the state as a whole was 8.34 inches in June, 1914. The lowest rainfall for any month was .05 inch in December, r9r3. 


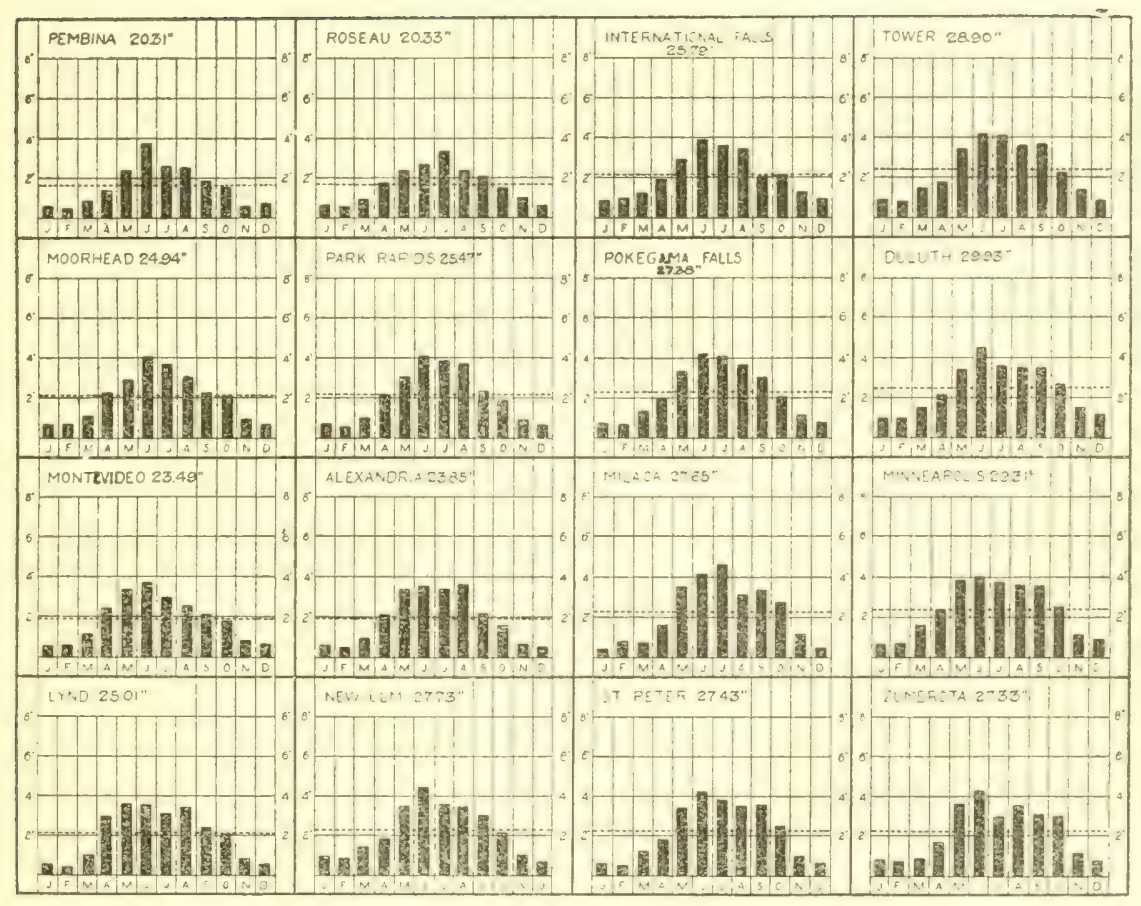

FIGURE I3. IIAGRAM SHOWING COMPARATIVE MONTHLY DISTRIBUTION OF PRECIPITATION IN MINNESOTA. LETTERS INDICATE MONTHS, BLACK COLUMNS INDICATE INCHES OF RAINFALL IN EACH MONTH AT STATTON NAMED 


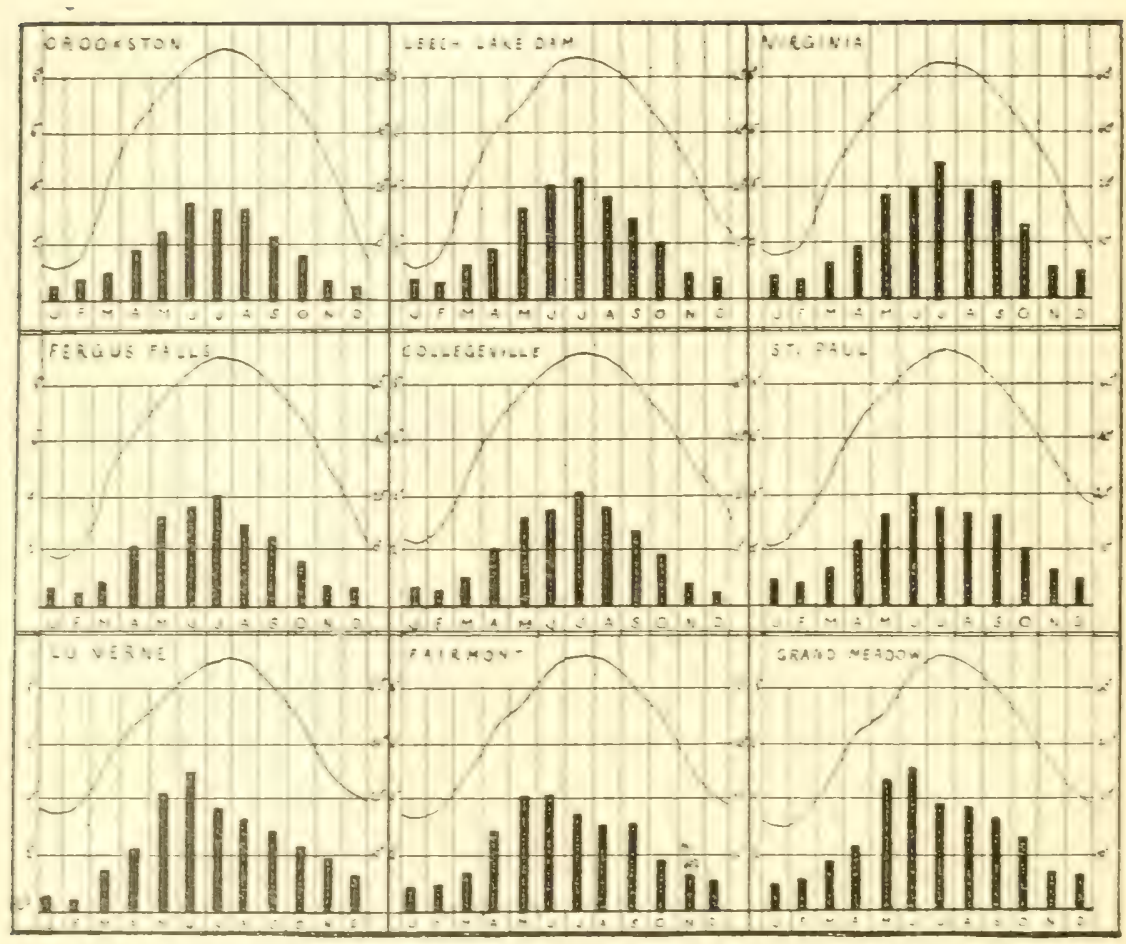

FIGURE I4 DIAGRAM SFOWIXIG MEAT MONTELY RAINFALT AND MEAN MONTHLY ZEMPERATURE AZ EEYMML STATIONS IT MIXXNESOTA. MONTHS ARE INDICATED BY IHEIR FIRSI LEIIERS. THE GREATESI RAIXFALI IS IX THE GROWTYG SEASON 


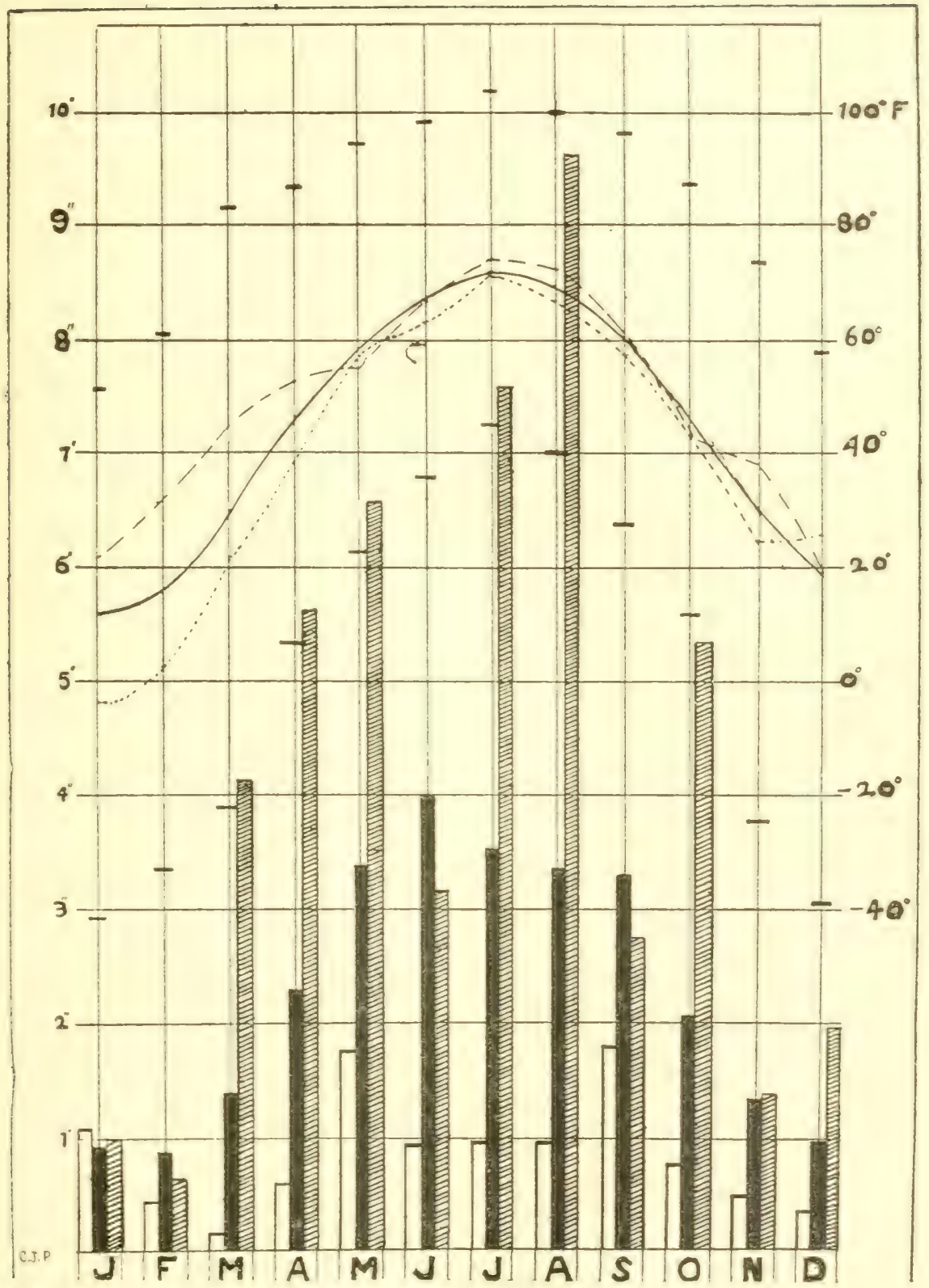

$\mathbf{9}=$ mean monthly rainfall, 1873.1913

Emonthly rainfall of year of greatest rainfall recorded, 1849 .

=montbly rainfall of year of least rainfall recorded, 1910 .

Solid curve =mean monthly temperature, 1871.5913

Dotted curve =mean monthly temperature for year of lowest annual temperature recorded, 1875.

Dashet curve $=$ mean monthly temperature for year of highest annual temperature recorded, 1878 ,

Horizontal dashes show absolute maximum and minimum temperatures recorded.

FIGURE 15. DLAGRAM SHOWING, RAINFALL AND TEMIPERATURES (DEGREES FAHRENHEIT) AT ST. PAUL, MINNESOTA FROM 1837-1913. MONTHS ARE

INDICATED BY THEIR FIRST LETTERS 
The geographic distribution of annual and monthly precipitation is graphically shown in Figures 12 to 14, and for the stations having ten or more years of record in Table V. Table IV shows the monthly and annual distribution in the various watersheds. From these illustrations it may be seen that the precipitation is about one-fourth to one-third greater along the eastern boundary of the state than along the western boundary.

Table V. Average Annual Precipitation in Minnesola by Stations

\begin{tabular}{|c|c|c|c|c|c|c|c|}
\hline Stations & County & 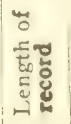 & 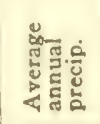 & Station & County & 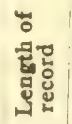 & 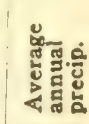 \\
\hline 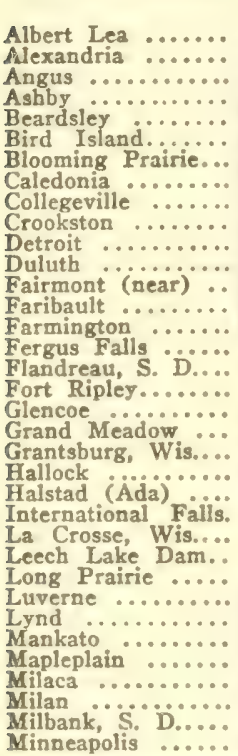 & 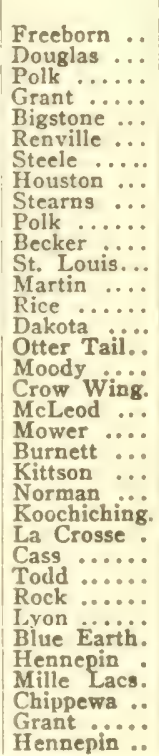 & $\begin{array}{l}Y 58 . \\
21 \\
25 \\
10 \\
14 \\
16 \\
22 \\
13 \\
19 \\
19 \\
22 \\
16 \\
41 \\
25 \\
14 \\
24 \\
24 \\
22 \\
43 \\
15 \\
24 \\
21 \\
13 \\
16 \\
10 \\
40 \\
24 \\
20 \\
15 \\
19 \\
14 \\
17 \\
13 \\
18 \\
21 \\
21\end{array}$ & $\begin{array}{c}\text { Inches } \\
29.90 \\
23.74 \\
19.00 \\
24.47 \\
23.79 \\
24.23 \\
27.45 \\
33.70 \\
22.76 \\
22.41 \\
25.96 \\
29.93 \\
28.20 \\
28.00 \\
29.29 \\
23.24 \\
24.57 \\
25.25 \\
26.64 \\
32.59 \\
33.06 \\
31.37 \\
31.27 \\
25.75 \\
31.17 \\
37.00 \\
25.17 \\
27.60 \\
25.43 \\
27.50 \\
31.11 \\
27.27 \\
24.49 \\
22.69 \\
29.31\end{array}$ & 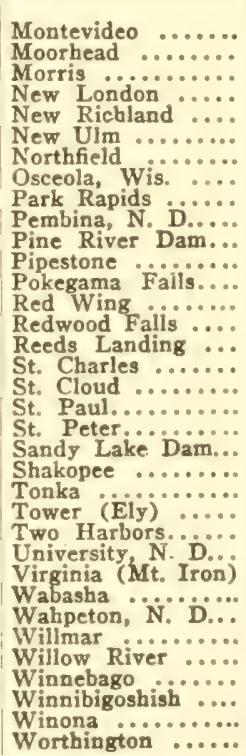 & 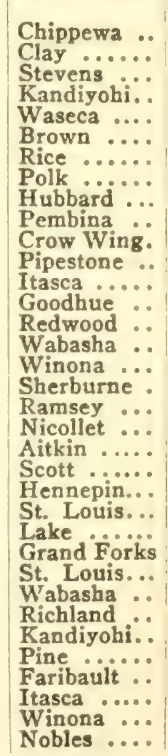 & \begin{tabular}{|c|} 
Yrs. \\
22 \\
31 \\
27 \\
18 \\
10 \\
32 \\
12 \\
21 \\
22 \\
22 \\
14 \\
25 \\
13 \\
25 \\
16 \\
13 \\
16 \\
21 \\
19 \\
41 \\
18 \\
19 \\
15 \\
13 \\
10 \\
18 \\
20 \\
18 \\
17 \\
20 \\
10 \\
10 \\
14 \\
35 \\
16 \\
17
\end{tabular} & $\begin{array}{r}\text { Inches } \\
23.50 \\
24.92 \\
23.23 \\
23.62 \\
39.91 \\
27.74 \\
39.92 \\
32.13 \\
25.71 \\
19.79 \\
27.52 \\
24.18 \\
27.62 \\
31.71 \\
24.65 \\
29.38 \\
30.68 \\
27.68 \\
28.68 \\
27.89 \\
26.47 \\
28.85 \\
30.54 \\
28.17 \\
30.56 \\
20.47 \\
30.74 \\
30.54 \\
23.67 \\
25.54 \\
39.98 \\
30.58 \\
25.66 \\
39.63 \\
28.24\end{array}$ \\
\hline
\end{tabular}

Figure I4 makes an interesting comparison of monthly and annual values of both temperature and rainfall at certain selected representative stations.

Snowfall.-The snowfall averages from 24 to 54 inches. It is lightest in the southwest portion of the state and heaviest on the Mesabi Iron Range. The monthly and annual averages are shown in Table VI, arranged according to sections and drainage districts.

Winds.-The prevailing winds are from the northwest over most of the state. The monthly and annual prevailing directions are shown for a large group of stations in Table VII. The average hourly wind velocity is shown for six regular Weather Bureau stations and three special stations in Table VIII. 
Table VI. Average Snowfall

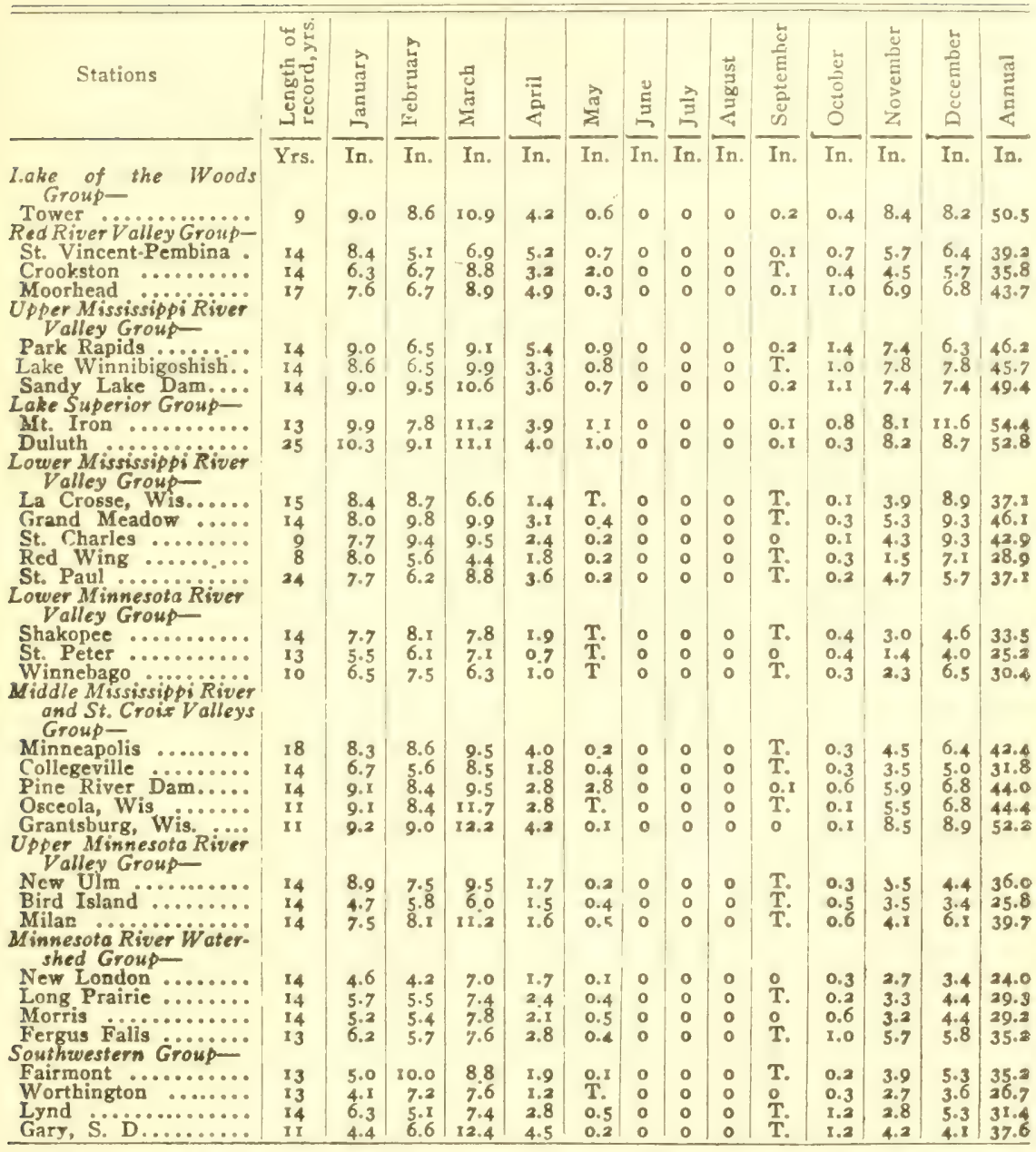

Relative humidity.-The average annual humidity for the state is 83 per cent at 7 a.m. and 72 per cent at 7 p.m. Table IX gives the monthly and annual data.

Number of rainy days. - In Table $\mathrm{X}$ the number of rainy days during each month and the year is given for thirty-three stations well distributed over the state. The smallest number is 64 at Lynd, Lyon County, and the largest 132 days at Duluth.

Sunshine.-The sunshine is abundant, averaging from 43 to 53 per cent of the highest amount possible. The daylight hours are materially longer during the crop-growing season in the northern portion of the state than in the southern. The greatest percentage of sunshine is in the southwestern portion and the least in the northeastern part. 
Table VII. Prevailing Wind Direction

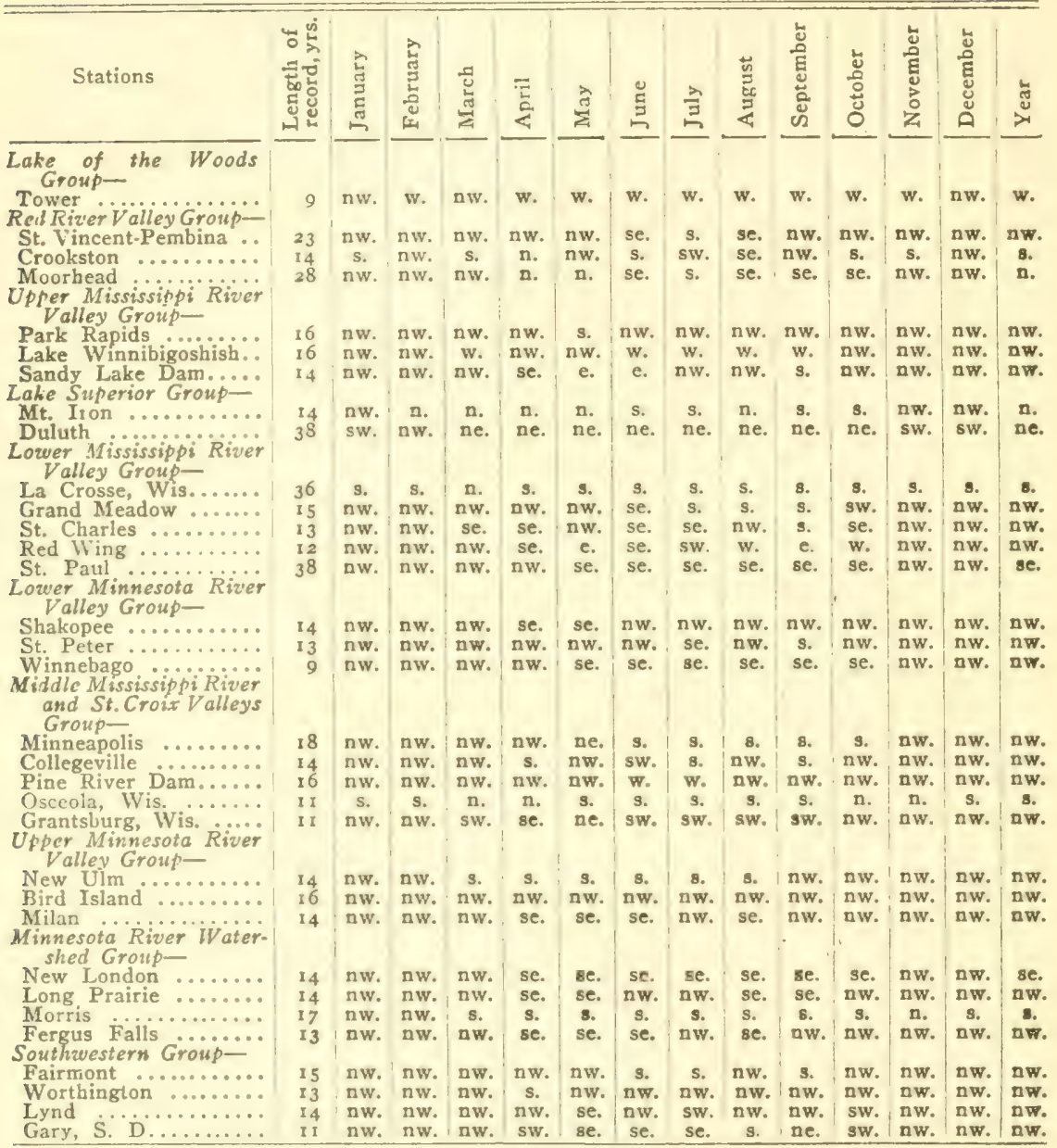

Table I'III. Average Hourly Wind Velocity in Miles

\begin{tabular}{|c|c|c|c|c|c|c|c|c|c|c|c|c|c|c|}
\hline Stations & 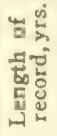 & 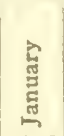 & 点 & 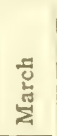 & 竞 & $\stackrel{\overrightarrow{3}}{\vec{a}}$ & 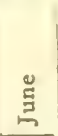 & $\frac{3}{3}$ & 峁 & 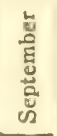 & $\frac{\frac{4}{0}}{\frac{0}{0}}$ & $\begin{array}{l}\text { है } \\
\text { है } \\
\text { ड़ } \\
0 \\
Z\end{array}$ & 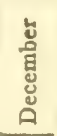 & है \\
\hline Duluth & 5 & 14.3 & 14.2 & I 5.0 & I 5.1 & 15.2 & $\mathrm{x} x .6$ & 11.3 & 12.0 & 12.7 & 13.9 & 14.1 & 14.2 & 13.6 \\
\hline Moorhead & 19 & 10.3 & 10.5 & I 1.3 & 12.0 & 10.7 & 10.0 & 8.3 & 8.4 & 10.4 & 10.4 & 10.1 & 10.0 & 10.2 \\
\hline La Crosse, Wis... & 36 & 7.1 & 7.5 & 8.0 & 8.5 & 7.5 & 6.7 & 6.0 & 5. & 6.9 & 7.5 & 7.5 & 7.2 & 7.2 \\
\hline St. Paul.......... & 36 & 7.8 & 8.3 & 8.8 & 9.3 & 8.7 & 7.7 & 7.1 & 7.1 & 8.0 & 8.5 & 8.1 & 7.8 & 8.1 \\
\hline Minneapolis ..... & 18 & 11.5 & 11.6 & 12.3 & 12.8 & 12.1 & 10.3 & 9.9 & 9.9 & I 1.6 & II.? & I 1.0 & 11.2 & I $x \cdot 3$ \\
\hline Faribault $\ldots . .$. & 7 & 9.4 & 9.1 & 9.4 & II.0 & 9.0 & 7.3 & 5.9 & 6. & 7.8 & 8.8 & 9.0 & 9.1 & 8.5 \\
\hline Collegeville ..... & Ii & 9.5 & 9.6 & 18.0 & 12.2 & II.I & 10.0 & 9.4 & 9.4 & 10.9 & 9.5 & 9.9 & 9.9 & 10.2 \\
\hline
\end{tabular}


Table IX. Mean Relative Humidity in Degrees

\begin{tabular}{|c|c|c|c|c|c|c|c|c|c|c|c|c|c|c|}
\hline Stations & 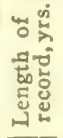 & 莺 & 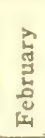 & 思 & ᄅ̈ & $\stackrel{\vec{J}}{\stackrel{\lambda}{\Sigma}}$ & $\stackrel{巳}{\Xi}$ & $\frac{2}{3}$ & 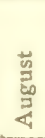 & 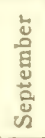 & $\begin{array}{l}\text { Jँ } \\
\stackrel{0}{0} \\
0\end{array}$ & 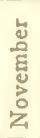 & 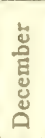 & 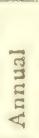 \\
\hline 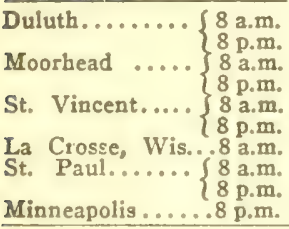 & $\begin{array}{r}21 \\
21 \\
21 \\
31 \\
4 \\
4 \\
21 \\
21 \\
21 \\
7\end{array}$ & $\begin{array}{l}83 \\
77 \\
89 \\
86 \\
80 \\
83 \\
83 \\
84 \\
76 \\
83\end{array}$ & $\begin{array}{l}83 \\
75 \\
88 \\
86 \\
80 \\
86 \\
82 \\
84 \\
75 \\
79\end{array}$ & $\begin{array}{l}81 \\
7 I \\
88 \\
82 \\
88 \\
88 \\
79 \\
81 \\
68 \\
76\end{array}$ & $\begin{array}{l}76 \\
65 \\
84 \\
65 \\
88 \\
77 \\
74 \\
75 \\
55 \\
66 \\
\end{array}$ & $\begin{array}{l}76 \\
64 \\
79 \\
56 \\
79 \\
58 \\
75 \\
75 \\
54 \\
66\end{array}$ & $\begin{array}{l}79 \\
69 \\
84 \\
62 \\
84 \\
66 \\
79 \\
79 \\
58 \\
67\end{array}$ & $\begin{array}{l}79 \\
65 \\
86 \\
64 \\
88 \\
71 \\
81 \\
79 \\
55 \\
65 \\
\end{array}$ & $\begin{array}{l}81 \\
69 \\
87 \\
61 \\
90 \\
70 \\
85 \\
83 \\
56 \\
68\end{array}$ & $\begin{array}{l}82 \\
71 \\
87 \\
63 \\
87 \\
71 \\
85 \\
83 \\
60 \\
72\end{array}$ & $\begin{array}{l}81 \\
72 \\
84 \\
69 \\
89 \\
78 \\
81 \\
81 \\
63 \\
73\end{array}$ & $\begin{array}{l}81 \\
69 \\
79 \\
\end{array}$ & $\begin{array}{l}84 \\
78 \\
89 \\
85 \\
87 \\
89 \\
83 \\
83 \\
76 \\
83\end{array}$ & $\begin{array}{l}81 \\
71 \\
86 \\
72 \\
86 \\
77 \\
81 \\
81 \\
64 \\
74\end{array}$ \\
\hline
\end{tabular}

Table X. Number of Days with o.or Inch or More of Precipitation

\begin{tabular}{|c|c|c|c|c|c|c|c|c|c|c|c|c|c|c|}
\hline Stations & 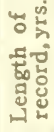 & 营 & 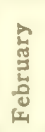 & 点 & द्व & 苾 & 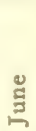 & $\stackrel{2}{3}$ & $\underset{3}{3}$ & 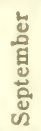 & 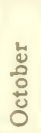 & 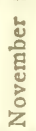 & $\begin{array}{l}\text { 巳ั } \\
\text { อू } \\
\text { ญू } \\
\text { อ }\end{array}$ & 章 \\
\hline \multicolumn{15}{|l|}{$\begin{array}{c}\text { Lake of the Woods } \\
\text { Group_- }\end{array}$} \\
\hline $\begin{array}{l}\text { Tower } \\
\text { RedRiverValley Group-.. }\end{array}$ & 9 & 5 & 4 & 6 & 5 & 8 & 9 & 10 & 8 & 10 & 7 & 5 & 5 & 82 \\
\hline St. Vincent-Pembina... & 25 & 7 & 6 & $?$ & 7 & 8 & II & 10 & 9 & 8 & 7 & 7 & 7 & 94 \\
\hline Crookston $\ldots . . . . . . .$. & 14 & 4 & 4 & 5 & 6 & 8 & 10 & 8 & 8 & 6 & 5 & 3 & 4 & 75 \\
\hline $\begin{array}{l}\text { Moorhead } \\
\text { Upper Mississippi River } \\
\text { Valley Group- }\end{array}$ & 28 & & 9 & 8 & 9 & II & 13 & 10 & 9 & 8 & 8 & 7 & 8 & 107 \\
\hline Park Rapids.......... & 14 & 8 & 7 & 10 & 9 & II. & 13 & II & 10 & 9 & 9 & 7 & 8 & I 12 \\
\hline Iake Winnibigoshish... & 15 & 6 & 4 & 7 & 6 & 10 & 10 & 9 & 8 & 7 & 5 & 5 & 6 & 83 \\
\hline $\begin{array}{l}\text { Sandy Lake Dam..... } \\
\text { Lake Superior Group- }\end{array}$ & 14 & 6 & 6 & 8 & 6 & 10 & 80 & so & 10 & 9 & 8 & 6 & 6 & 95 \\
\hline 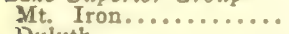 & 14 & 5 & 4 & 5 & 5 & 9 & II & 10 & 9 & 9 & 7 & 5 & 6 & 85 \\
\hline $\begin{array}{l}\text { Duluth } \\
\text { Lorer Mississippi River } \\
\text { Valley Group- }\end{array}$ & 38 & 10 & 9 & Io & 9 & 12 & 14 & 12 & 12 & 12 & 10 & II & II & 132 \\
\hline La Crosse, Wis....... & 36 & 10 & 8 & 10 & 10 & 12 & 12 & 10 & 9 & Io & 9 & 8 & 10 & 120 \\
\hline Grand Meadow........ & 15 & 6 & 5 & 7 & 7 & 32 & 9 & 9 & 8 & 8 & 7 & 6 & 6 & 90 \\
\hline St. Charles........... & 12 & 5 & 4 & 6 & 6 & 9 & II & 7 & 6 & 8 & 7 & 5 & 4 & 78 \\
\hline Red Wing............ & 10 & 5 & 5 & 6 & 7 & II & 10 & 7 & 7 & 8 & 6 & 5 & 5 & 82 \\
\hline $\begin{array}{l}\text { St. Paul. } \\
\text { Lower Miniesota } \\
\text { Valley Group- }\end{array}$ & 38 & 9 & 8 & 10 & Io & 12 & 12 & 10 & 10 & 9 & 9 & 8 & 9 & $I_{14}$ \\
\hline Shakopee .................... & 14 & 5 & 5 & 7 & 8 & II & ro & 9 & 9 & 9 & 8 & 6 & 5 & 93 \\
\hline St. Peter............. & 12 & 3 & 3 & 5 & 6 & 10 & 9 & 7 & 7 & 6 & $\mathbf{5}$ & 3 & 2 & 66 \\
\hline $\begin{array}{l}\text { Winnebago } \\
\text { Middle Mississippi River } \\
\text { and St. Crois Valleys } \\
\text { Group- }\end{array}$ & Io & 4 & 4 & 6 & 6 & 12 & II & 9 & 9 & 7 & 7 & 3 & 4 & 82 \\
\hline Minneapolis .......... & 18 & 8 & 7 & 9 & 9 & 12 & 12 & 9 & 9 & 8 & 9 & 7 & 8 & 107 \\
\hline Collegeville $\ldots . . . . .$. & 14 & 6 & 5 & 8 & 7 & 10 & 12 & 10 & 80 & 9 & 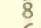 & 6 & 5 & 96 \\
\hline Pine River Dam...... & 15 & 4 & 4 & 6 & 6 & 9 & so & 8 & 8 & 7 & 6 & 4 & 4 & 76 \\
\hline Osceola, Wis.......... & II & 7 & 5 & 6 & 6 & 8 & 9 & 8 & 7 & 6 & 7 & 5 & $\sqrt{2}$ & 79 \\
\hline $\begin{array}{l}\text { Grantsburg, Wis....... } \\
\text { Upper Minnesota River } \\
\text { Valley Grouk }\end{array}$ & 11 & 5 & 4 & 5 & 6 & 8 & 7 & 7 & 6 & 5 & 4 & 5 & 6 & 68 \\
\hline 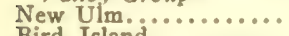 & 14 & 5 & 5 & 7 & 7 & II & 81 & 8 & 8 & 8 & 7 & 5 & 4 & 86 \\
\hline Bird 1sland........... & I4 & 4 & 3 & 6 & 7 & 10 & 10 & 8 & 8 & 8 & 6 & 5 & 3 & 78 \\
\hline $\begin{array}{l}\text { Milan } \\
\text { Minnesota River Wä Wör- } \\
\text { shed Group- }\end{array}$ & 14 & 6 & 5 & 7 & 7 & 9 & II & 8 & 8 & 7 & 6 & 5 & 5 & 84 \\
\hline New London.......... & 14 & 3 & 3 & 5 & 5 & 9 & 9 & 7 & 6 & 6 & 5 & 4 & 3 & 65 \\
\hline Long Prairie........... & $x 4$ & 4 & 4 & 6 & 8 & 10 & II & 8 & 8 & 8 & 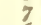 & 5 & 3 & 82 \\
\hline Morris ........... & 16 & 4 & 4 & 6 & 7 & II & 12 & 9 & 9 & 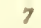 & 6 & 4 & 4 & 83 \\
\hline $\begin{array}{c}\text { Fergus Falls.......... } \\
\text { Southwestern Group - }\end{array}$ & $x_{3}$ & II & 8 & II & 9 & 12 & 15 & II & II & 10 & 8 & 7 & 10 & 133 \\
\hline 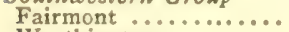 & 15 & 4 & 4 & 5 & 6 & 10 & 8 & 7 & 7 & 7 & 5 & 3 & 3 & 69 \\
\hline Worthington...$\ldots$. & 13 & 4 & 4 & 4 & 6 & II & 10 & 14 & 8 & 6 & 5 & 4 & 4 & 80 \\
\hline Lynd $\ldots \ldots \ldots \ldots . . . . .$. & 14 & 3 & 3 & 5 & 5 & 8 & 9 & 3 & 8 & 6 & 4 & 3 & 3 & 64 \\
\hline Gary, S. D.......... & Ii & 3 & 2 & 3 & 5 & 6 & 5 & 6 & 5 & 4 & 4 & 3 & $i$ & 47 \\
\hline
\end{tabular}


The precipitation in the area embraced in the present report, as shown in Figure 12, increases from northwest to southeast, being about 25 inches in the northwest part and over 32 inches in the southeast. Although there is an increase on approaching Lake Superior the influence of the lake in increasing precipitation near its shore seems to be very slight, for in parts of Minnesota farther south where there is no lake influence a similar increase in the amount of precipitation is found in passing from northwest to southeast. 


\section{AGRICULTURAL CONDITIONS AND LAND CLASSIFICATION IN THE SOUTH HALF OF MINNESOTA}

\section{GENERAL STATEMENT}

The area embraced in this report extends from the median line of the state, about latitude $46^{\circ} 25^{\prime}$, southward to the Iowa state line. It embraces about 40,000 square miles, including lakes. It is largely tributary to the Mississippi River, there being only about 3,550 square miles, or less than 9 per cent drained by other streams. Of this, 60 to 70 square miles in the northeast corner of Pine County drains northeastward to Lake Superior; about I,840 square miles is tributary to Red River of the North; and r,650 square miles is drained southwestward to the Missouri River. In the Mississippi drainage about I5,000 square miles falls within the Minnesota River watershed, and over 2I,000 square miles in the main stream and other tributaries of the Mississippi. Part of this is drained by the Des Moines, Cedar, and upper Iowa rivers across Iowa to the Mississippi, while the St. Croix River flows along the border of the state to its junction with the Mississippi.

The altitude of the south half of the state has a range of about $I, 350$ feet, the lowest being 6 I 5 feet, at the southeast corner of the state, and the highest I,950 to I,975 feet, in high points on the Coteau des Prairies in the southwest part. The average altitude is not far from I,200 feet. Only a small part aside from river valleys is below $\mathrm{r}, 000$ feet, and only a small part above $I, 500$ feet.

The average rainfall ranges from less than 24 inches, in the western part, to 30 to 32 inches in the eastern (Figure 12). The rainfall is largely in the crop-growing season, and is usually sufficient for the proper maturing of all the crops.

As indicated in the discussion of the general features of the state, the topographic and agricultural conditions are quite varied. It may, therefore, be of advantage to outline briefly certain of the characteristics of each of the several classes of land, beginning with the driftless area, and taking up the several drifts and associated deposits in order of their age and the alluvial deposits of the present streams.

\section{DRIFTLESS AREA}

The portion of Minnesota falling within the driftless area of the upper Mississippi valley is confined to Houston County and the eastern part of Winona County. In this area the uplands have a residuary clay covering the rock to a depth of a few feet, above which there is a deposit 
of wind borne silt-loam (loess) having a depth of Io to 15 feet or more. This loess extends down on the gentle slopes from the crests of the divides between the streams, leaving only the steeper part of the slopes with rock exposed. This area is, therefore, rendered more productive by the presence of the deposit of loess which has buried the less productive residuary clays beneath it. The steep parts of the slopes which are difficult to till are utilized to a large degree for pasture.

\section{LOESS-COVERED PRE.WISCONSIN GRAY DRIFT}

Pebbly border.-For several miles back from the eastern limits of the old drift there are usually only scattered pebbles and occasional bowlders to mark the former extent of glaciation. The topography is indistinguishable from that of the driftless area, and the glaciation was usually so weak that the preglacial residuary clay is still present on the rock formation. A sheet of loess covers the pebbles to a depth of to to I 5 feet or more, and it is this which gives the productiveness to the soil. A considerable part of Wabasha County, western Winona County, eastern Olmsted County, eastern Fillmore County, and western Houston County falls within the limits of this pebble and bowlder area. Rock bluffs are about as conspicuous as in the driftless area, but the valleys of tributaries of the Mississippi are narrower than on the lower courses of the streams in the driftless area proper.

Old gray till (Kansan).- The loess overlaps for a few miles the eastern edge of heavy deposits of an old calcareous till. This was leached to a depth of several feet before the deposition of the loess, and is usually oxidized to a yellowish brown color to a depth of 15 to 20 feet. When of greater thickness, it retains the original bluish gray color. Eastern Goodhue County, southwestern Wabasha County, western Olmsted County, northeastern Dodge County, and part of the western half of Fillmore County, have thick deposits of old drift beneath the loess. The loess, however, is so heavy a deposit as a rule that the crops are dependent upon it rather than upon the underlying drift. The amount of this drift is sufficient to reduce greatly the roughness of the surface.

There is an area of the old gray drift in the southwest corner of the state in Rock, Pipestone, and Nobles counties, of which about I 70 square miles in the extreme southwest corner of the state, were covered by a deposit of loess to several feet in depth, or of sufficient thickness to entirely sustain the crops. This gives place on the north and east somewhat abruptly to a thin coating of wind drifted silt a few inches to 2 or 3 feet in depth which is not included in the area mapped as loess on the map of the surface formations of Minnesota. Much of the deposit is probably derived from the loess, but the silt is mixed to some extent with sand 
grains and small pebbles from the underlying till. It appears to have been deposited by winds that were dragging the surface and transporting coarse and fine grains gathered from bare or exposed surfaces of loess or till, a process still in operation. The typical loess, on the other hand, is a very uniform deposit, such as might result from the settling of dust which had been held in the atmosphere. It is not always feasible to draw a definite line or boundary between the deposits, but the map sets forth the approximate extent of the typical loess.

The drift is sufficient in southwest Minnesota to fill the preglacial valleys, but some of the more prominent quartzite ridges stand above the general level of this drift filling. Parts of these ridges are entirely bare, but they seem likely to have formerly carried a coating of drift which has been removed by erosion, for the glaciated surfaces of the rocks frequently have the striae well preserved. This could hardly be the case if they had been exposed to weathering ever since the ice disappeared from this region. The depth of leaching in this old drift is much less than in southeastern Minnesota, being usually but 2 to 3 feet or even less. The difference seems attributable in part at least to the smaller rainfall and a lesser amount of downward penetration of water in southwestern Minnesota.

\section{OLD GRAY DRIFT (KANSAN), WITH LITTLE OR NO LOESS COVER}

Immediately west of the loess covered area in southeastern Minnesota is an old gray drift with little or no silt cover over it, which extends westward and passes under the young or Wisconsin gray drift of southern Minnesota. From the state line northward across Mower, Dodge, western Goodhue, eastern Rice, and southwestern Dakota counties, it is very largely composed of clayey till which has been leached of its lime to a depth of several feet, and oxidized to a depth of about i 5 feet, below which it retains the original bluish gray color. It has been termed in the earlier reports of the Minnesota Geological Survey the old gray drift. A large part of it appears to be of Kansan age, and its surface was greatly eroded subsequent to the Kansan glaciation.

\section{IOWAN DRIFT OVER KANSAN DRIFT}

The southeast part of Minnesota and the northeast part of Iowa include an area which differs somewhat from Kansan drift areas farther south. The general depth of leaching is less than in those areas, and the surface of the drift is not so deeply reddened by oxidation. The valleys in this area are in some cases mere swales without definite bluffs, and as a rule they are shallower than in the Kansan drift areas to the south. There are knolls on the slopes and on the valley bottoms, which in some 
cases seem to have been deposited in the form of knolls rather than developed by erosion of material around them. In a few places in northeastern Iowa an old soil, which is thought by some geologists to be at the top of the Kansan drift, has over it a thin drift deposit, usually 5 to Io feet or less in depth.

These features have led certain geologists to think that a readvance of ice into this region took place at a time between the Kansan and Wisconsin stages of glaciation. Opinion is divided as to whether this readvance took place at the Illinoian stage of glaciation or at some later time more nearly contemporaneous with the main loess deposition. Pending the solution of this matter, and the full determination of the significance of the peculiar features just mentioned, a special name, Iowan, has been applied to it. Because of the vagueness of the features the limits of the Iowan drift, or the extent of Iowan glaciation, are matters on which there is wide difference of opinion.

So far as the Minnesota area has been affected by such a post-Kansan glaciation, the effect on crop conditions is likely to be slight. There has been, perhaps, a slight removal of the leached and weathered surface of the Kansan drift in exposed situations, and redeposition of this material in the valleys and depressions. The valleys of this problematical area often head in shallow draws or sloughs which are wet and ill-drained, but the district is entirely free from lakes and inclosed basins such as abound in the later or Wisconsin drift region. Aside from the sloughs just mentioned the drainage is naturally good.

\section{OLD RED DRIFT (ILLINOIAN), OVER OLD GRAY DRIFT (KANSAN)}

In central and eastern Dakota County, northern Goodhue County, and southeastern Washington County, the Kansan or old gray drift has been covered by drift of a somewhat different constitution and color, made up largely of the classes of rock found in the red drift of western Wisconsin and like that apparently deposited by ice from the north or northeast. The clayey portions usually have a red color which is strikingly in contrast with the yellowish brown color of the underlying Kansan drift. It is markedly more weathered than the red drift of Wisconsin age but corresponds in degree of weathering to the Illinoian drift.

This old red drift is generally very stony and it seldom assumes a clayey constitution. It is usually but a few feet in depth, and scarcely makes a continuous cover over the Kansan drift. It includes, however, a prominent range of gravelly hills in southern Dakota County which extends from near Hampton southeastward for several miles in a strip about 2 miles in width. This line of hills has the appearance of a terminal moraine, and there is a somewhat knolly surface eastward from it 
into northern Goodhue County and northward to Etter, which may mark the continuation of an ice border.

This old red drift is an extensive outlying deposit in western Wiscon$\sin$, but its exposure in Minnesota seems confined to the parts of the three counties above named.

\section{YOUNG OR WISCONSIN RED DRIFT (PATRICIAN ICE SHEET)}

The young Patrician red drift of the eastern part of this area has been so overridden by later deposits from the Superior lobe of the Labrador ice field, and those of the Keewatin ice field, that it is exposed only in detached areas. One of these areas occupies much of Washington and Ramsey counties and the northern part of Dakota County. It comprises moraines of considerable strength having a stony clayey till, the soil being a stony loam. Associated with the moraines are small outwash plains of gravel and sand in the district north of the Mississippi River, and more extensive outwash plains along and south of the Mississippi River, a considerable part of central and northeastern Dakota County being occupied by these plains.

This strong system of moraines is traceable westward beneath the young gray drift across northern Scott County and the district north of the Minnesota valley in Carver, Hennepin, and Wright counties to where it emerges in Stearns County on the north side of the Grantsburg lobe of the young gray drift. It runs thence northward across central Stearns and eastern Todd counties, and thence northeastward across northwestern Morrison County into Cass County, where it passes beyond the limits of the area here discussed. It has been encroached upon slightly in Stearns and Todd counties by the later advance of the Keewatin ice field, but a large portion of it is still exposed to view. It is generally composed of a very stony clay with stony loam soil.

To the east of this morainic system, occupying much of Morrison, Benton, Mille Lacs, Kanabec, and Pine counties, there is a relatively smooth district of the red Patrician drift, largely till plain, but traversed by a few narrow morainic ridges and including also a few gravel ridges or eskers. The till is a stony clay and often is thickly strewn with bowlders. The clay, however, is of sufficient amount to give a heavier soil than that in the moraines. This is likely to become an important grass growing area and dairy district. A large part of it is as yet very poorly developed, for it was occupied by a mixed coniferous and hardwood forest which was difficult to clear.

Another strong morainic system of the red Patrician drift sweeps around the west and south sides of Mille Lacs Lake and runs eastward across southern Aitkin and northwestern Pine counties, and there passes 
beneath the drift of the Superior lobe a few miles south of the north limits of the area under discussion. This morainic system has a width of 4 to 8 miles and is composed largely of stony clayey till with stony loam soil. Outwash plains of gravel and sand border it on the west in Crow Wing County and are included among its ridges in northwestern Pine County.

North and east of Mille Lacs Lake is a till plain of red Patrician drift extending eastward and passing beneath the moraines of the Superior lobe in the southern part of Aitkin County. As yet this till plain is very thinly settled, but its soil is suitable for pasture and meadows, like that of the till plain to the south of the moraine which borders the west and south sides of Mille Lacs Lake.

In the till plain in Morrison, Benton, and Mille Lacs counties the young red drift is so thin that the courses of the interglacial valleys are still traceable. These valleys were cut in the old gray drift which underlies that part of Minnesota at least as far east as Mille Lacs Lake.

\section{YOUNG OR WISCONSIN RED DRIFT (LABRADORIAN ICE SHEET)}

The Superior ice lobe of the Labrador ficld extended but a few miles south of the median line of the state in northern Pine and southern Aitkin counties. Its border runs east to west across the northern part of Pine County, and its moraines cross the moraines of the red Patrician drift at a slight angle, the course of the Patrician moraines being there southwestward. There are extensive swampy areas at the terminus of the lobe in southern Aitkin County, with occasional knolls scattered through them, and outside of this to the west a sandy plain which seems to be an outwash from the ice lobe. Narrow till plains are inclosed between the constituent ridges of the moraines of the Superior lobe. There are also numerous swamps interrupting the morainic ridges all along their course across Pine County. The moraines are also interrupted by a gravelly plain extending northward from Willow River past Sturgeon Lake which seems to have been a main line of discharge from the Superior ice lobe down Kettle River to the St. Croix and the Mississippi.

The drift of the Superior lobe within this area is largely of clayey till with scarcely as many stones as characterize the Patrician drift. Its soil is, however, a stony loam.

\section{BORDER OF YOUNG GRAY DRIFT (KEEWATIN ICE SHEET) IN CENTRAL MINNESOTA}

There is a narrow strip running southward through western Cass, eastern Wadena, and central Todd counties in which the old gray drift is near the surface and has over it a deposit which contains some rocks such as abound in the red drift. The presence of such drift suggests 
that the Patrician ice may have extended over that area. There are indications also that the Keewatin ice field in later Wisconsin time covered the same area for the greater part, but without making a heavy deposit. The surface material is a mixture of rocks of red drift in gray drift which might have been produced by the incorporating of the pre-Wisconsin gray drift with the Wisconsin red drift of the Patrician ice field. Or it might have been produced by the encroachment of the Keewatin ice on the thin edge of the red drift and incorporation of that drift in the Wisconsin gray drift. That the latter seems to have been the case is inferred from certain peculiarities of topography. The surface presents a peculiarly smooth appearance as far east as the edge of the strong moraine of red drift which runs through eastern Todd County, and the smoothness in places runs up a slope to that moraine. There is no uncertainty of the presence of the Keewatin ice to within a few miles of the west base of the strong red drift moraine, for a definite sheet of young gray drift is found at the surface in the western part of Todd and Wadena counties, and westward from there. The small amount of red drift that is incorporated with the gray in the district west of the prominent red drift moraine has had but little effect upon the character of the soil. It is somewhat more stony than the unmodified gray drift, but has nearly as great fertility as the gray drift ordinarily possesses.

There are narrow morainic ridges of the young gray drift in southwestern Todd and eastern Douglas counties, but a large part of the surface is a relatively smooth plain. In Wadena and eastern Otter Tail counties, there are extensive gravel plains which were largely formed as an outwash from the strong moraines farther west. In western Stearns County a moraine of considerable strength follows down Sauk River, being south of the river from Sauk Center to New Munich and north of the river from there eastward to Cold Spring, beyond which it is merged with later moraines considered below. On either side of this moraine there are till plains with a thin cover of young gray drift. The plain on the northeast extends to the base of the strong moraine of red drift, above discussed, and in places the young gray drift is found veneering the slopes of the red drift moraine; a condition which shows clearly that the Keewatin invasion here culminated after the Patrician ice had begun to recede.

\section{BORDER OF YOUNG GRAY DRIFT IN SOUTHWESTERN MINNESOTA}

In southwestern Minnesota, as in central Minnesota, there is a thin sheet of relatively young gray drift, forming a veneer over the eroded surface of the old gray drift, which lies outside the well defined moraines of Wisconsin drift. It covers the southwest corner of Lincoln County 
and a large part of Pipestone County, the southwest corner of Murray, the northeast corner of Rock, and a considerable area in western Nobles County. It is so thin a deposit that the interglacial valleys cut in the old gray drift are but partially filled and are followed in large part by the modern streams. It contains a mixture of old gray drift with the young gray drift, and masses of the old are often included in this younger deposit, and are easily recognized by the high degree of staining and oxidation as compared with that of the young drift which incloses them. This border district lies outside the limits of a moraine which has been considered by Upham as the limit of the later or Wisconsin drift. It differs from that inside the limits of that moraine in having few undrained basins or depressions. In the latter district the interglacial lines of drainage were more completely filled with the younger drift than in that outside the moraine, so that drainage lines are more generally opened in new courses instead of following the lines of interglacial valleys. In the opinion of the present writers, the drift which veneers the eroded district outside the moraine is not markedly older than that of the moraine which Upham interpreted to be the outer limits of the younger drift, and should, therefore, be included with it.

\section{MORAINES OF SOUTHWESTERN MINNESOTA}

A series of strong moraines was formed on the southwest side of the Keewatin ice field in the Wisconsin stage. The outermost of these moraines is the one traced by Upham. It follows the crest of the Coteau des Prairies across Lincoln, Pipestone, Murray, and Nobles counties. It consists of a single ridge as far south as Chandler in Murray County, but from there southward to the state line it has two members separated by a narrow till plain.

Between this moraine and the next younger morainic system there is a narrow till plain in Lincoln County, but it widens out in Murray, Nobles, and Jackson counties and has a width of nearly 30 miles in northeastern Nobles and northwestern Jackson counties. It narrows again on approaching the state line.

The morainic system east of this plain is very strong and complex. Its several constituent morainic ridges are either merged together or closely associated throughout their course in southwestern Minnesota. They traverse western Yellow Medicine, northeastern Lincoln, southwestern Lyon, northeastern Murray, southwestern Cottonwood, and central Jackson counties, and occupy a belt from 8 to 16 miles wide. They all lie along the northeast slope of the Coteau des Prairies, so that the inner ones are at a lower altitude than the outer ones. 
These moraines are composed largely of clayey till, but include occasional gravel knolls and the till in places becomes very stony. The plains associated with these moraines have a rich black loam soil.

\section{MORAINES OF SOUTHEASTERN MINNESOTA}

From the state line northward to the Minnesota River in a belt embracing much of Freeborn, Steele, Waseca, Rice, eastern Le Sueur, and Scott counties there is a morainic system which was formed on the east side of the Keewatin ice field at the Wisconsin stage of glaciation, and which apparently is the equivalent of the entire series of moraines on the west side just noted. There is also to the east of the outermost strong moraine a narrow strip of Wisconsin drift in which the surface is nearly all plane and the drift thin.

In Scott and Rice and eastern Le Sueur counties the moraines are all bunched together with only narrow strips of till plain among them. But to the southward in Steele and Freeborn counties the till plains between the moraines in places reach a width of several miles.

The moraines are composed largely of clayey till with a pebbly clay loam soil, but gravel knolls are scattered along them, and in places the till is very stony. The till plains have a black clay loam soil of darker color and somewhat less stony drift than the moraines. There are small outwash aprons of sand and gravel associated with the moraines.

\section{OVERLAP OF RED DRIFT BY GRAY DRIFT IN GRANTSBURG LOBE}

In the district north of the Minnesota River the Keewatin ice made a great protrusion northeastward over an area that had been lately vacated by the Patrician ice, and deposited a sheet of the young gray drift on the surface of the young red drift. The extent of overlap is in the neighborhood of 75 miles. The end of the lobe is found near Grantsburg, Wisconsin, opposite the southern end of Pine County, Minnesota, but the ice encroached so little on the Wisconsin side of the St. Croix River that glacial drainage appears to have been but slightly interrupted by the extension beyond the river.

A portion of the overlap on the southwest side of the Mississippi River in Wright, Hennepin, and Carver counties shows a veneering of strong red drift moraines by a relatively thin deposit of the gray drift. The gray drift deposit, however, becomes thick enough within a few miles of its border to conceal completely the red drift deposits.

On the northeast side of the Mississippi River the area covered by the Grantsburg lobe has been extensively blanketed by dune sand which covers much of Sherburne, Isanti, and Anoka counties, and extends to the St. Croix River in Chisago County. There are, however, morainic 
ridges and narrow till plains standing in these areas of dune sand, but most of them are composed largely of stony drift which the Keewatin ice gathered up from the sheet of Patrician drift which it overrode, and incorporated with some of its own more calcareous material. The topographic features also seem due mainly to the Keewatin ice advance. In some cases what had been a gravel plain of red drift has been changed into a ridged or morainic area by a disturbing and heaping up of its deposits, with a veneering mixed with gray till.

The dune sands appear to have lodged generally on the clayey areas of the Keewatin drift and not on the gravel and sand areas. In some cases they are on moraines and in others on till plains. The sand is so fine as to have considerable capillary action, and by thus supplying moisture in dry seasons, has yielded fair returns where cultivated. Bands of fine dust-like deposits in the sand increase its fertility. Situated as it is near the markets of St. Paul and Minneapolis, vegetable growing or market gardening is likely to become a profitable enterprise. It is an important potato growing area.

At the northeast end of the lobe in southern Pine and northern Chisago counties, and also in eastern Chisago County there are till plains associated with narrow morainic ridges, all having a rich pebbly, clay loam soil.

\section{GRAY DRIFT MORAINES OF CENTRAL MINNESOTA}

Along the east side of the Keewatin ice field, as already indicated, there was a thin border drift. This is succeeded on the west by a very strong system of moraines which comes into the area under discussion from the north in Otter Tail County, and runs southeastward across Douglas, Pope, northeastern Swift, and central Kandiyohi counties. It branches in eastern Kandiyohi County, and the outer or northern member bears north of east from New London past Paynesville to the chain of lakes north of Eden Valley, and then turns southeastward and runs between Watkins and Kimball into northwestern Wright County, and thence northeastward into the Grantsburg lobe already discussed. The portion north and east of Watkins is at the extreme border of the young gray drift. But farther west it falls short of reaching the red drift border, the interval being filled by the relatively thin border portion of the young gray drift.

The southern or inner member of the great morainic system continues southeastward from central Kandiyohi County to the northwest corner of McLeod County, where it turns abruptly northeastward to form the northwest border of the Grantsburg lobe. By that time the lobe was considerably shrunken, and had its terminus near the Mississippi River. 
The moraines of the Grantsburg lobe which correlate with this inner part of the great morainic system curve around in Wright County and run southward across Carver and western Hennepin counties to the Minnesota valley.

This great morainic system is bordered on the east by extensive outwash plains of gravel and sand in Otter Tail, Douglas, Pope, southwestern Stearns, and northern Kandiyohi counties. The drainage was thence down the Mississippi along Sauk River. Farther east there were outwash plains near Kimball which found their drainage eastward to the Mississippi along lines south of Sauk River. Farther east near South Haven and Annandale the outwash plains slope northward to the Mississippi at Clearwater.

From the inner morainic system there was an outwash northward near Litchfield and Darwin into a small lake that occupied the plain bordering North Crow River between Kingston and Manannah, and which discharged northward past Eden Valley and the chain of lakes north of that village to Sauk River valley and thence to the Mississippi. There are also smaller lines of glacial drainage coming into this lake from the west at Manannah. The ice at that time was covering the lower course of Crow River below Kingston, and thus caused the ponding of the waters west of that village. The outwash plains and glacial drainage lines in Meeker County have a fine sandy to gravelly soil, but the old lake bed is covered by a fine lacustrine silt nearly free from pebbles.

This great morainic system is composed of coarse stony drift along much of its eastern border with numerous gravel knolls and ridges included. But as one passes westward or southwestward toward the inner border of the morainic system, a clayey till is found to come in gradually, while gravel knolls and ridges become more and more infrequent. There are occasional small areas of outwash plain in the midst of the morainic system in Otter Tail and Douglas counties, but such features are remarkably rare.

\section{THE GREAT PLAIN OF THE MINNESOTA LOBE}

The axis of movement of the Keewatin ice field was along the Minnesota valley from Swift County, near Appleton, to the great bend of the Minnesota at Mankato, and there is found on either side of the river a broad plain rising gradually toward the border of the great morainic systems above discussed. That on the north side of the river covers much of Swift, Chippewa, Kandiyohi, Renville, McLeod, Sibley, and Nicollet counties, while that on the south covers the greater part of Lac qui Parle, Yellow Medicine, Lyon, Redwood, Cottonwood, Brown, Watonwan, Martin, Blue Earth, and Faribault counties. 
On this plain a few weak moraines were developed, which mark successive positions of the ice border as it was melting back from the vicinity of Mankato to the headwater part of the Minnesota River. Along the outer border of these moraines are found channels of border drainage which eventually enter the Minnesota, usually along the line of modern streams. They, however, cross from one modern river valley to another because the ice was still covering the lower courses of the more northern and western streams. Thus border drainage which follows the course of Yellow Medicine River will cross over to that of Redwood River and then to Cottonwood, and perhaps to the Watonwan before entering the Minnesota. These channels are better defined on the south than on the north of the Minnesota River, probably because the melting of the ice was more rapid on that side.

In connection with the border drainage there was more or less ponding of the waters along the edge of the ice, so the channels are not continuous from each one of the modern valleys to a neighboring valley in every instance. The effect of this ponding was to cause a deposition of silt over the till, but it seldom reaches a depth of more than a few inches. The ponding was also so short-lived that beaches or definite shore lines seem not to have been developed.

This great plain is largely prairie, and the soil is a rich black loam on its level portions, and a pebbly clay loam on the morainic ridges. These morainic ridges often include gravelly knolls which are of much value in furnishing material for the roads. The portions of the border drainage channels not now utilized by streams are often marshy and ill-drained, but can usually be reclaimed by ditching. The dry portions of the border drainage channels usually have a sandy soil.

Yellow Medicine River is somewhat peculiar in its drainage, in the portion immediately above Hanley Falls. The plain there is so flat that the river has developed a number of channels which branch out and come together again, thus inclosing areas of several square miles in some cases.

The Minnesota valley was broadly and deeply excavated by the outlet of Lake Agassiz. In several places it has branching channels which inclose strips of the upland, sometimes several miles in length and only a mile or two in width, as indicated on the general map (Plate I). Below Montevideo, however, it has a single broad channel. All along its course there are rock ledges standing up prominently in the bottoms.

THE GREAT RED RIVER PLAIN

Only the eastern part of this plain lies in Minnesota, the western being in the Dakotas. The Red River valley and its southward continuation 
in the basin drained by the Mustinka and the Bois des Sioux rivers was the axis of movement of the Keewatin ice field. The terminus of the ice lobe was at one time in a moraine which runs along Big Stone Lake and thence eastward across southern Big Stone County into northwestern Swift County, and thence northward along or near the Chippewa River to its source in northeastern Grant County. The ice was thus a broad lobe at its southern end, markedly out of harmony with the last stages of the ice in the Minnesota valley below Big Stone Lake, which had been reduced to a very narrow lobe, as indicated by the moraines each side of the valley. From this it is inferred that the ice made a decided readvance with broader front at the time it reached the position marked by the moraine just outlined. Extensive outwash plains of fine sandy gravel were developed just outside this moraine in southeastern Stevens, western Pope, and northwestern Swift counties, and also in southern Big Stone County.

Between this moraine and the shore of Lake Agassiz there is an extensive till plain covering much of Stevens and Big Stone counties and part of Grant and Otter Tail counties, on which an occasional slight indication of later positions of the ice border are traceable in weak ridges and low hummocks. The ridges are better defined in Grant and Otter Tail counties than farther south. The ice eventually shrank within the linits of the Lake Agassiz area in Traverse, Grant, and Wilkin counties.

THE LAKE AGASSIZ AREA

The portion of the Lake Agassiz area in the southern half of Minnesota lies mainly in Traverse and Wilkin counties, but it touches northwestern Stevens, western Grant, and southwestern Otter Tail counties. The soil is sandy for a few miles at the southern end of this lake area, but elsewhere is a heavier soil. The lake clays are of very slight depth, usually but a few inches, and the till is at the surface over most of the lake bed embraced in the area under discussion. In the northern part of Traverse County, bowlders are exceedingly numerous.

The beaches or shore lines formed at several levels are usually composed of fine gravel suitable for use on roads. They also have been used as lines for highways and for buildings sites.

The soil on the flat areas is a rich black loam, and even the sandy portions have a black sandy loam.

\section{OUTWASH SAND AND GRAVEL PLAINS}

There is perhaps no other surface formation in the state that differs so greatly in the character of the soil and in agricultural value as the outwash plains of sand and gravel. In some places these plains have a 
rich cover of black loam, several inches to several feet in depth, which renders them about as fertile as any land in the state; while at the other extreme they may have a soil or surface of loose sand or gravel subject to drouth and relatively unfertile. Between these extremes the grades of soil range from poor to fair or good. In the present survey the separation and mapping of the extent of each grade of soil in the outwash plains has not been attempted. In the county discussions, however, statements have been inserted which serve to indicate to some extent the local variations in the character of the soil on these plains. But a much more detailed soil survey must be made to bring out properly the agricultural values of each section.

\section{ALLUVIAL BOTTOMS}

There are broad alluvial bottoms along the Minnesota River throughout its course from Big Stone Lake to the Mississippi, and along the Mississippi below St. Paul. Those on the Mississippi are subject to overflow at high river stages, and can only be cultivated with profit in the driest years. The lower portion of the Minnesota valley is in process of silting up, for the valley was cut by the outlet of Lake Agassiz to a level 20 to 30 feet below the present level of the stream. The lakes on the border of Scott and Hennepin counties are unfilled parts of this deep channel. The Minnesota valley has stretches of very slight fall immediately above the rock rapids which occasionally appear along its course. In such places the river may be expanded into a lake, as is the case at Lac qui Parle and in Marsh Lake.

The tributaries of the Mississippi River in southeastern Minnesota usually have broad alluvial flats extending some distance up from their mouths, but these are seldom subject to overflow and are in large part under cultivation.

The portion of the Mississippi above Minneapolis has a broad valley formed as a line of glacial drainage, whose bed is a light sandy soil. The stream in postglacial time has cut a small trench in this broad valley. St. Croix River has broad bottom lands in southern Pine and northern Chisago counties, but below high banks border the stream somewhat closely except at Lakeland where there are broad terraces with sandy soil. The lower course of the river, however, below Stillwater is expanded into a lake, known as Lake St. Croix.

\section{FARMING DEVELOPMENT IN MINNESOTA}

The census of 1850 gives Minnesota only 5,035 acres, or about 8 square miles of improved land. This was in 157 farms, or an average of 32 acres per farm. In 1860 there were 556,250 acres, or about 870 


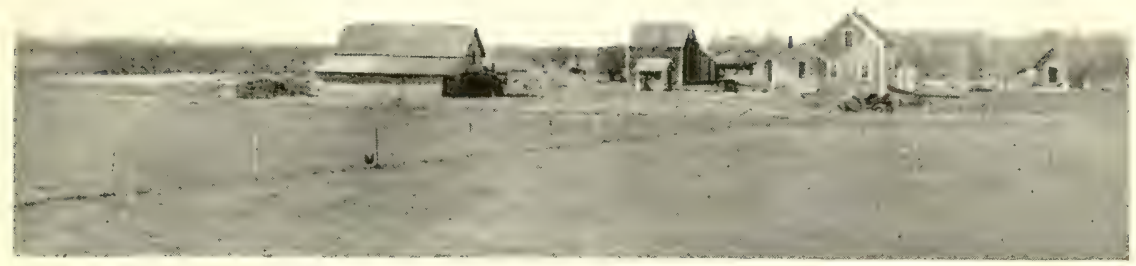

4. BED OF LAKE AGASSIZ NEAR WHFATON

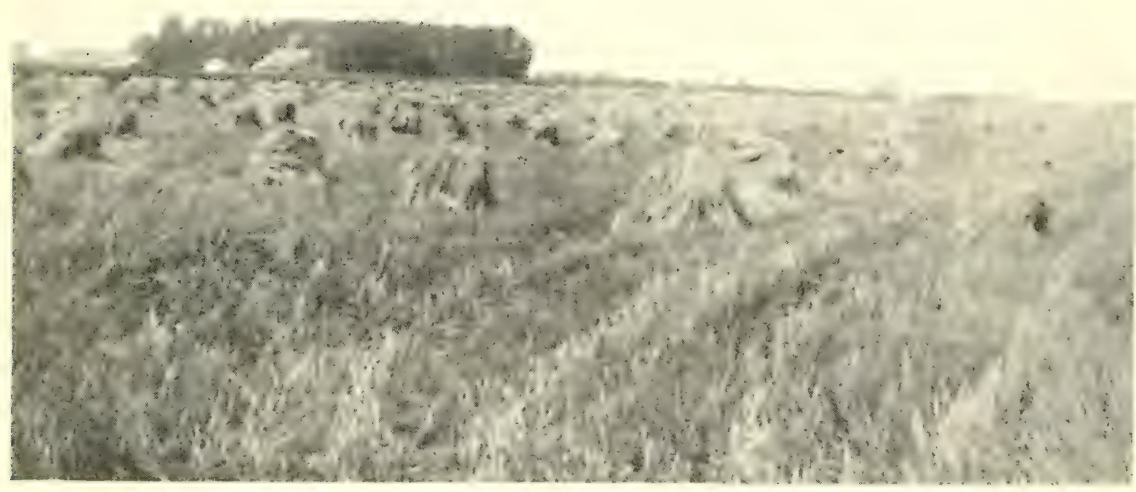

B. (iRAIN FIELD IN BED OF LAKE AGASSIZ NEAR WHEATON

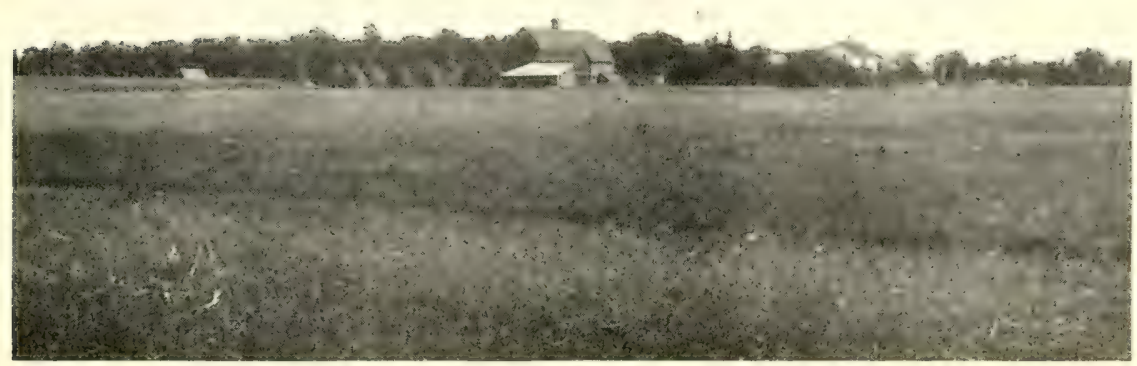

C. GRAY DRIFT TILI, PLAIN IN CHISAGO COUNTY 

square miles of improved land. There were I8,I8I farms with an average of about $3 \mathrm{I}$ acres of improved land. There were only 2,924 farms, or 16 per cent, with more than 50 acres of improved land. It thus appears that farming was still in its beginnings as late as 1860.

The farms down to that time were very largely along the river bottoms and in the oak openings in the southeast part of the state. Such forests are easily cleared, and the stumps soon decay; so the pioneers expended only a moderate amount of time and labor in changing these oak openings into agricultural land. This land, too, was naturally well drained, much of it being covered with loess which is a readily pervious silt which would absorb the rainfall rapidly. It also holds moisture and yields it to the crops through capillary action in the dry seasons. The settlements were confined to a narrow belt along the rivers within about a day's haul by team, and the navigable waters of the Mississippi, the St. Croix, and the Minnesota furnished avenues of shipment to the markets. The yield of wheat on the fertile loess soil was high, and this soon became the staple crop. In an early day flour mills were erected along many of the tributaries of the Mississippi, which utilized the water power afforded by these streams. So long as wheat raising was highly profitable, there was very little stock raising. The long cold winters probably also tended to check the stock raising, but by 1870 the wheat yield in the southeastern counties had begun to fall off, and this led to more diversified farming. The seasons in the early 1860's were very favorable for wheat raising, and the yield in the years from 1860 to 1865 averaged about 22 bushels per acre, or $4^{1 / 2}$ bushels above the average for the state in IgIo.

Down to 1870 the settlement was almost entirely in the forested areas of the eastern part of the state. The settlements were very slowly extended into the prairies, not only on account of their remoteness from navigable waters, but also because of lack of fuel and the bleakness of the region and lack of windbreaks. There seems also to have been a feeling of uncertainty as to the productiveness of the prairie land, it being inferred that the lack of timber was due to some deficiency in the soil.

Between 1860 and 1870 , notwithstanding the repressing influence of the Civil War, there was a great extension of agriculture over the greater part of the southern half of the state. A few prairie counties in the southwest part, and the densely wooded counties east of the Mississippi River, however, received very few settlers prior to I870. Immediately after the Civil War railroad extension became rapid, and by the early I870's railroads had been extended to the western and southwestern parts of the state and on into the Dakotas. The line from St. Paul to Duluth also connected the agricultural district with this Great Lakes 
port, and other lines from the western part of the state were soon connected with Duluth.

Although settlement started in the forested portion of Minnesota, that part has now a smaller percentage of improved land than the prairie portion of the state. The prairie counties usually have from 70 to 85 per cent classed as improved land, while the older settled forested counties, such as Wright, Hennepin, and Carver have but little more than half their area classed in the census of 1910 as improved land. There has been, however, a steady increase in the percentage of improved land in the forested counties, thus showing there is not an abandonment of farming but merely a slow development due in large part to the difficulty of clearing the land.

It is in the forested areas that swamp lands are most extensive, and they as well as the forests greatly check the development of agriculture. The most extensive swamps and marshes in the southern half of Minnesota are found in the district east of the Mississippi River, in Pine, Kanabec, Mille Lacs, Isanti, and Anoka counties. In the forested district west of the Mississippi there are numerous lakes, some of which have marshy borders. There are also basins deeply filled with peat inclosed among the morainic hills and ridges. Systematic ditching after careful surveys should greatly decrease the amount of swamp land. In some of the prairie counties, lakes which are represented on the land survey plats, and which still appear on the county atlases, have in many places been completely drained and their beds been converted into agricultural land.

The table, on page 6r, compiled from census reports gives the growth of agriculture in each county in the southern half of the state decade by decade from 1870 to 1910.

\section{RANK OF DIFFERENT CROPS IN MINNESOTA}

As shown by the census of 1910 , the acreage of cereals in Minnesota has the following order from highest to lowest: Wheat, oats, corn, barley, rye. The amount of tame grass cut is but little more than that of wild grass, there being 2,885,987 tons of tame grass, and 2,7 I4, I 2 I tons of wild grass cut in 1909. The acreage of wild grass was but slightly higher than that of the tame grass, there being $1,815.250$ acres of tame grass, and $1,988,664$ of wild grass.

Wheat leads in 32 of the 63 counties here reported on in the southern part of the state, while oats leads in 20 of them. Corn leads in 5 counties, Anoka, Freeborn, Hennepin, Houston, and Sherburne counties, all in the southeast part of the state. Barley leads in Dodge, Goodhue, Lincoln, Olmsted, Wabasha, and Winona counties, all but one in the southeast part of the state. Wheat leads in the great till plains of the Wisconsin 
Per Cent of Improved Land of Counties in Southern Half of Minnesota by Decades, I87o to Igro

\begin{tabular}{|c|c|c|c|c|c|c|}
\hline County & 1870 & 1880 & 1890 & I 900 & I9IO & Dominant Soil and Vegetation \\
\hline in & * & * & 0.20 & 77 & 97 & everal soils. \\
\hline$\ldots \ldots$ & 2.87 & I 2.80 & 0 & 4 & 0 & Sand, mixed gray drift. Scr \\
\hline$\ldots \ldots$ & 0.98 & o & & 10 & 0 & Clayey red drift. Hardwoo \\
\hline ig Sitone & & & & 56 & 22 & Clayey gray drift. Prairie. \\
\hline Ea & 21.00 & & & & & Clayey gray drift, Prairie \\
\hline$\ldots \ldots$ & $\varepsilon$ & $\begin{array}{l}8 \\
7\end{array}$ & & & & $\begin{array}{l}\text { Clayey gray dritt. Prairie, } \\
\text { Mixed and clayey gray drift }\end{array}$ \\
\hline hewa & I & 0 & 25 & & & Clayey gray drift. Prairie. \\
\hline go : & & 0 & & 20 & & Clayey gray drift, sand. H \\
\hline nwoo & 0.19 & I) & & 40 & & \\
\hline $\begin{array}{l}\text { Wing } \\
\text { ota } \ldots . .\end{array}$ & 4 & & $\begin{array}{l}70 \\
30\end{array}$ & & 7 & $\begin{array}{l}\text { veral soils. Mixed for } \\
\text { avelly red drift. Oak }\end{array}$ \\
\hline$g, ? \quad \cdots$ & 2 & 87 & 2 & bo & 77 & Clayey old gray drift. Pra \\
\hline lits $\ldots \ldots \ldots \ldots$ & & & 9 & I & 5 & xed gray drift. Hardwo \\
\hline $\begin{array}{l}\text { ianlt } \\
\text { lore. }\end{array}$ & 1. & & & & & drift. Prairic \\
\hline $\begin{array}{l}\text { illmore } \cdots \ldots \ldots \\
\text { recborn } \ldots \ldots \ldots\end{array}$ & 3 & 0 & & & & old gray drif \\
\hline odhue $\ldots \ldots \ldots . . .$. & 44 & 5 & 5 & 4 & 6 & $\begin{array}{l}\text { Clayey to mixed gray drift. } \\
\text { Loess, clayey old gray drift. }\end{array}$ \\
\hline it $\ldots \ldots \ldots \ldots$ & c & 9 & & 4 & 7 & Clayey gray drift, part lake \\
\hline$\ldots \ldots \ldots$ & I & 6 & & 3 & 3 & ced gray drift. Hardwo \\
\hline$=t(111) \quad \ldots \ldots \ldots$ & 0 & c & & 5 & 47 & lual, alluvial. C \\
\hline ti $\cdots$ & 2.70 & 0 & 0 & & & d gray drift. O \\
\hline $\begin{array}{l}111 \\
1 \times 0\end{array}$ & $\mathrm{I}_{*} 2 \mathrm{O}$ & I.3. & & 5 & & drift. Prairic. \\
\hline diyohi & & & & & & $\begin{array}{l}\text { Clayey to } \\
\text { Clayey to }\end{array}$ \\
\hline qui Parle..... & & 20 & 8 & 4 & & $\begin{array}{l}\text { Clayey to mixed gray drift. } \\
\text { C.layey gray drift. Prairie. }\end{array}$ \\
\hline ir. & I 2.50 & 7 & & & & Clayey to mixed gray drift. \\
\hline$\ldots \ldots$ & 1 & $\begin{array}{l}c \\
c\end{array}$ & & & $\frac{7}{7}$ & $\begin{array}{l}\text { Clayey to mixed gray drift. } \\
\text { Clayey gray drift. Prairie. }\end{array}$ \\
\hline$t^{\prime} \ldots \ldots \ldots$ & 6.76 & c & & & & $\begin{array}{l}\text { Clayey gray drift. Prairie. } \\
\text { Clayey gray drift. Hardwor }\end{array}$ \\
\hline $\operatorname{tin} \ldots \ldots \ldots \ldots$ & 4.23 & OC & & 2 & 81 & Clayey gray drift. Prairie. \\
\hline iet $\ldots$ & 5.42 & 32.27 & 3 & 65 & 68 & ey to mixed gray drift. \\
\hline$\cdots$ & 0.48 & I. $8 \mathrm{c}$ & 0 & o & 1. & Clayey to mixed red drift. \\
\hline$i<0 n$. & 0.48 & $4.9 \mathrm{C}$ & 0 & 8 & 2 & Clayey to mixed red drift. \\
\hline er $\cdots$. & 14.40 & 55 & 86 & 6 & 86 & Clayey old gray drift. Pra \\
\hline let $\ldots$ & 18.00 & $\begin{array}{l}70 \\
0 C\end{array}$ & 0 & 0 & 78 & $\begin{array}{l}\text { Clayey to mixed gray drift. } \\
\text { Clayey gray drift. Prairie. }\end{array}$ \\
\hline $\begin{array}{l}\text { llet } \ldots \\
(\because \ldots\end{array}$ & & $\begin{array}{l}6 \\
1\end{array}$ & & & & $\begin{array}{l}\text { ey gray drift. Prairie. } \\
\text { gray drift. Prairie. }\end{array}$ \\
\hline tedin & 40 & 14 & & & & $\begin{array}{l}\text { ey gray drift. Prairie. } \\
\text { s, clayey old gray drift. }\end{array}$ \\
\hline r Tailt.. & 0.28 & is & 34 & 72 & 6 & ed gray drift. Prairie, \\
\hline & $t$ & $\begin{array}{l}0.20 \\
7.30\end{array}$ & & & & eral soils. Mixed forest \\
\hline stone $\ldots$ & 2. & $0 \mathrm{C}$ & & 38 & & gey gray drift, partly old. \\
\hline & 9.9 & oc & & 0 & & $\begin{array}{l}\text { ced gray drift. Prairie and } \\
\text { ced red drift. Oak. }\end{array}$ \\
\hline $\begin{array}{l}\text { ey } \\
\text { ondind }\end{array}$ & + & $\begin{array}{l}0 \mathrm{I} \\
60\end{array}$ & & 7 & & $\begin{array}{l}\text { ced red drift. Oak. } \\
\text { yey gray drift. Prai }\end{array}$ \\
\hline illen $\ldots$ & I. 5 & $\begin{array}{l}60 \\
20\end{array}$ & 30 & & & $\begin{array}{l}\text { Clayey gray drift. } \\
\text { Clayey gray drift. }\end{array}$ \\
\hline C & 30 & 20 & & & & $\begin{array}{l}\text { Clayey gray drift. } \\
\text { Mixed gray drift. }\end{array}$ \\
\hline 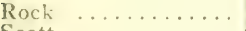 & & 98 & $\begin{array}{l}.46 \\
5.29\end{array}$ & & 0 & $\begin{array}{l}\text { ed gray drift. Ha } \\
\text { ss, clayey old gray }\end{array}$ \\
\hline$\cdots \cdots$ & .00 & 99 & & & & $\begin{array}{l}\text { ss, clayey old gray drift. } \\
\text { yey to mixed gray drift. }\end{array}$ \\
\hline - burne. & 5 & 70 & & & & ed gray drift, sand. Sc \\
\hline ey $\ldots$. & 8.35 & I & 43 & 2 & & ey gray drift. \\
\hline ns $\ldots$ & 6.33 & 41 & 3 & & & ral soils. Ifardwc \\
\hline nis & $\begin{array}{r}17.27 \\
0.27\end{array}$ & 6 & 3 & & & ey to mixed gray drift. \\
\hline ens & $\begin{array}{l}0.27 \\
\text { I. } 12\end{array}$ & 0 & & 12 & & $\begin{array}{l}\text { ey gray drift. } \\
\text { ey to mixed g }\end{array}$ \\
\hline it $\ldots \ldots$ & $\begin{array}{l}\text { I. I } 2 \\
0.61\end{array}$ & 30 & 8 & 0 & & $\begin{array}{l}\text { xed gray drift. } \\
\text { ed red and gray d. }\end{array}$ \\
\hline erse $\ldots$ & 0.8 & $\begin{array}{l}7.80 \\
4.50\end{array}$ & & & 8 & $\begin{array}{l}y \text { to mixed red and gray drifts. M } \\
\text { silt and sand, clayey gray drift. }\end{array}$ \\
\hline ha $\ldots$ & & & so & & & s, alluvial. Oak \\
\hline a & & 36 & & I. $6 \mathrm{I}$ & & yey gray drift. Prairie, \\
\hline ingtorll & & .03 & & & & yey to mixed red drift. \\
\hline wan. . . & 02 & 21.90 & 5 & $\begin{array}{l}8 \\
4\end{array}$ & 6 & $\begin{array}{l}\text { ey to mixed gray drift. } \\
\text { e sfrliment. clinvey gray }\end{array}$ \\
\hline ona $\cdots$ & 33.48 & .88 & .96 & & $5 x$. & $\begin{array}{l}\text { sfriment, clavey gray drif } \\
\text { 5, alluvial. Prairie, oak. }\end{array}$ \\
\hline $\begin{array}{l}\text { Wright } \\
\text { Yellow Mé }\end{array}$ & & $x^{2}+2$ & & & & $\begin{array}{l}\text { to mixcl gray drift. Ha } \\
\text { ey to mixed gray drift. Pr }\end{array}$ \\
\hline & & & & & & ey to mixed gray \\
\hline
\end{tabular}

* Less than one square mile improved in 1870 .

* Several counties combined with Redwond County, with 1,074 acres improved land in whole area.

$\$$ Part of county in northern half also included. 
drift bordering the Minnesota valley, and in most of the older settled counties in central Minnesota. Oats leads in the poorly settled counties of eastern Minnesota, and in 7 counties of southwestern Minnesota. In the tables under each county the order of importance of each cereal is given, from highest to lowest.

\section{RELATION OF CROP VALUES TO FARM INVESTMENTS IN SOUTHERN MINNESOTA}

The gross income from crops, as given by the census of I9IO, and as quoted in the tables in connection with each of the counties here discussed, shows a range in the different counties from about 9 per cent to I7 per cent of the total value of the farm property in the respective counties. The following table gives the percentage for each county:

\section{Annual Gross Income of Crops in Per Cent of Farm Values}

Per cent

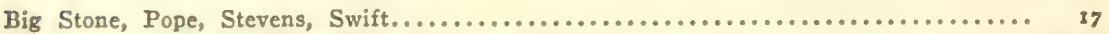

Chippewa, Grant, Renville, Traverse.................................... 16.16.7

Douglas, Isanti, Kandiyohi, Lac qui Parle, Meeker, Stearns, Wilkin................ I5.I5.8

Benton, Morrison, Nicollet, Sherburne, Sibley, Wabasha, Yellow Medicine............ 14.14.7

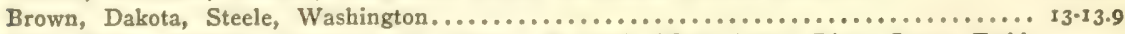

Blue Earth, Chisago, Goodhue, Le Sueur, McLeod, Mille Lacs, Rice, Scott, Todd,

Waseca, Winona, Wright..................................... 12.12.9

Anoka, Carver, Cottonwood, Freeborn, Hennepin, Houston, Lincoln, Lyon, Olmsted, Pine,

Ramsey, Watonwan ........................................

Dodge, Faribault, Fillmore, Jackson, Martin, Mower, Pipestone.................... 10.10.5

Kanabec, Murray, Nobles, Rock....................................... 9. 9.7

In 8 counties in the southwest part of the state the gross income is I6 to 17 per cent, but in 3 others, also in the southwest part, it is less than Io per cent. This difference is not a difference in productivity of soil, but seems due largely to the higher estimate of value of land in these 3 counties. It serves to show that prices in these counties have reached, if they have not already gone beyond, profitable use by the present occupants, for the gross income is ordinarily more than double the net income, or real return for farm investments. There are 7 more counties in the southern part in which the gross income is only Io to I0.5 per cent of the valuation. A large number of counties scattered over the southern half of the state have a gross income between II and 16 per cent. 


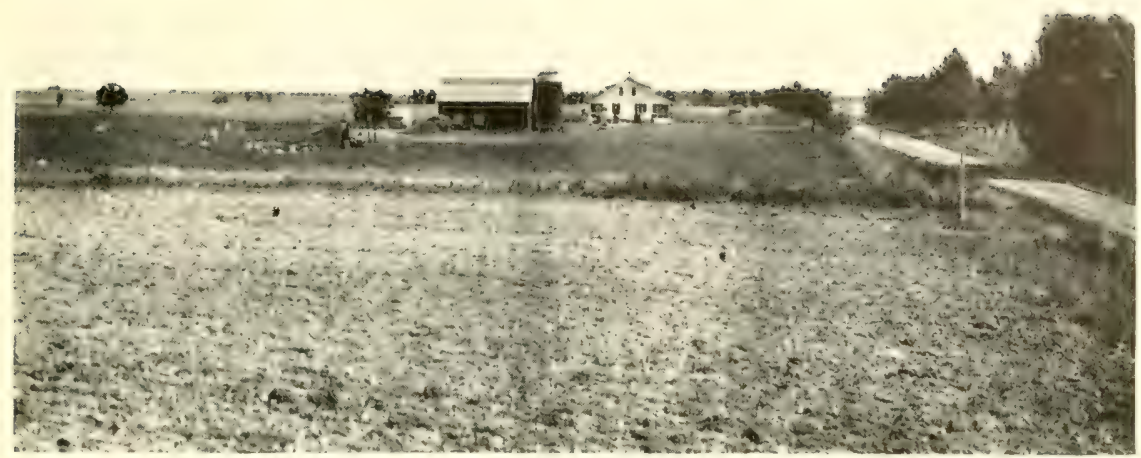

4. CULTIYATED RED DRIFT TILL PLAIN NEAR FOLFY

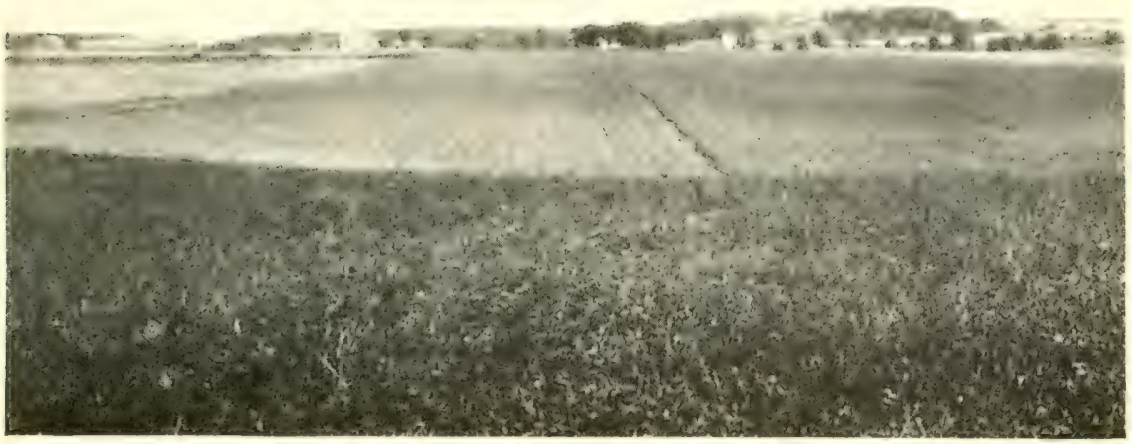

B. IRED DRIFT TILI PLAIN WTTH FOREST NEMR FOLEY

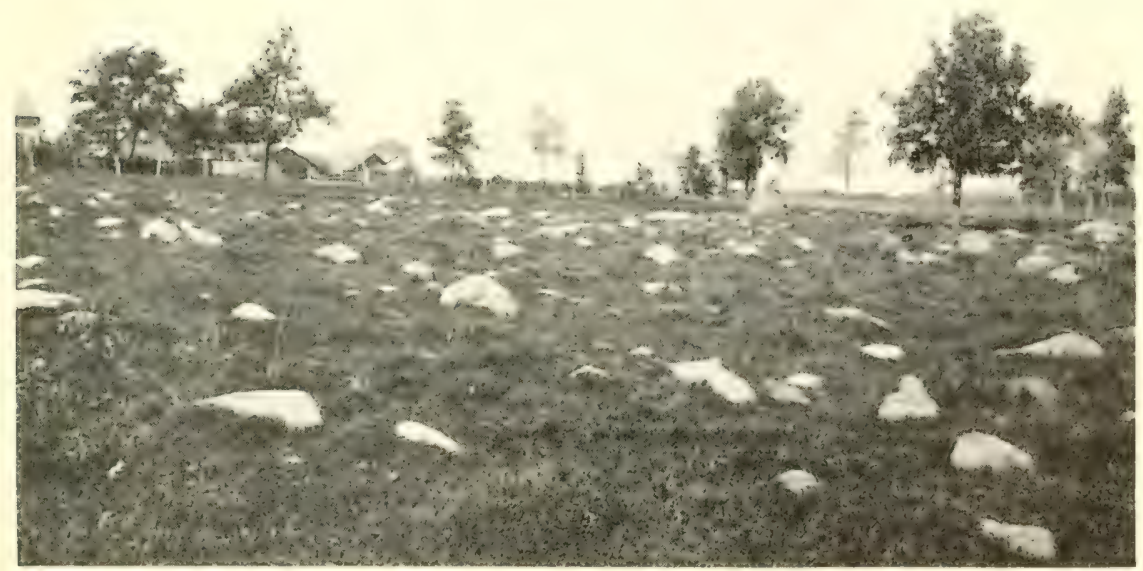

C. BOULDERS ON RED DRIFT TILL PLAIN NEAR FOLEY 



\section{DESCRIPTIONS OF COUNTIES}

In the description of counties which follows, the county taken first is in the northeast corner of the area, and after this counties to the west and south to the southern border of the state are discussed. A few data from the census of I9Io are presented in addition to the results of the land classification on a geologic basis.

\section{PINE COUNTY}

Pine County is located in the northeast corner of the area embraced in this report, its eastern boundary being the state line of Minnesota and Wisconsin. Its land area is I,4I3 square miles, and the water area of its meandered lakes and streams is 24.76 square miles. It embraces a large amount of poorly drained land classed as swamp on the Land Office plats, there being 387 square miles, or about 27 per cent of the county as computed from these plats. The greater part of this may be readily drained at moderate expense. A few places were noted in the northeast part, however, where the swamps are held in by barriers of rock, and others where prominent drift ridges and knolls inclose them. But in most cases the swamps are due in part to fallen timber and beaver dams which may be easily removed. As a result of the great Hinckley fire which some years ago swept a large tract in the southwest part of the county, the area of some of the swamps was markedly reduced, and peat beds were burned out leaving the soil exposed. In the settlements near Bruno and also near Beroun, the swamp areas have been greatly reduced and rendered tillable. In some cases the swamp lands were pastured for a few years after the water was drained away, and before they were cultivated.

This county is somewhat unique in that it was encroached upon by each of the three ice fields in the Wisconsin stage of glaciation. The Superior ice, however, covered only a narrow strip with red drift along the north border of the county, and the Keewatin ice a few townships of gray drift at the southern end. In the remainder of the county the Patrician red drift is at the surface, and it also underlies the other drifts. There was glacial drainage from the Superior lobe down the Kettle River, from the Patrician ice down the St. Croix River, and from the Keewatin ice along Snake River. The St. Croix also served as an outlet for the glacial Lake Duluth, which produced a large valley with sandy and in part swampy bottoms. The Keewatin or young gray drift at the 
southern end of the county is largely of clayey texture and high fertility. The red drift is more stony, though much of it has a clayey admixture both in moraines and till plains. It will be likely to be excellent grass land, and the county as a whole may become a profitable region for dairying and stock raising.

Rock hills Io to 20 feet high, covering a few acres each, are found in the swamps and among the morainic knolls in the northeastern part of the county, and there are rock exposures along the streams in the southern part. The combined area, however, appears to be but little more than I per cent of the county.

In the northern part of the county farming is extended but little east of the Great Northern Railroad, but in the southern part it extends over the entire width of the county.

Percentages of Classes of Land in Pine Connty

\begin{tabular}{|c|c|c|}
\hline & Square miles & Per cent \\
\hline 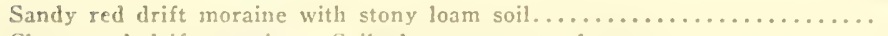 & 60 & 4.2 \\
\hline 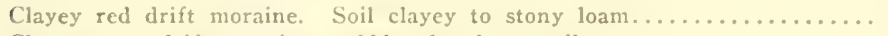 & 280 & 19.7 \\
\hline 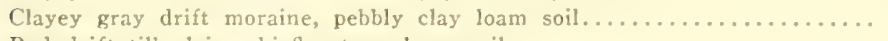 & 20 & I.4 \\
\hline 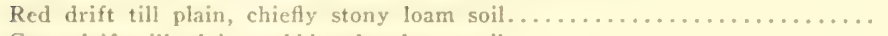 & 290 & 20.5 \\
\hline 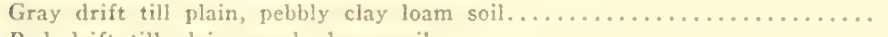 & 58 & 4.I \\
\hline 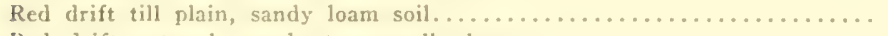 & I00 & 7.1 \\
\hline 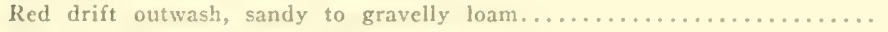 & $137)$ & 15.8 \\
\hline 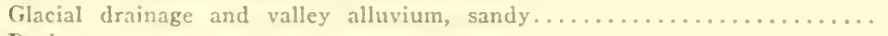 & $87\}$ & \\
\hline 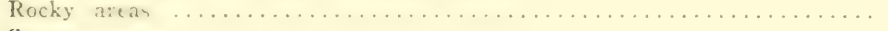 & 15 & I. I \\
\hline 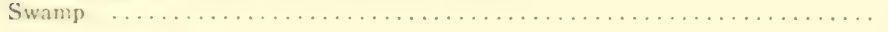 & 366 & 25.9 \\
\hline & 413 & 99.8 \\
\hline
\end{tabular}

Farm and Crop Data for Pine County from Census of 1910

Rural population 10,627 or 7.5 per square mile.

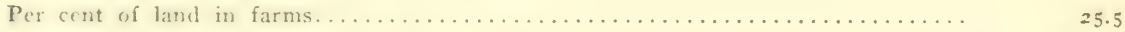

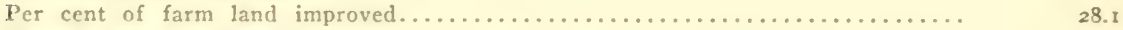

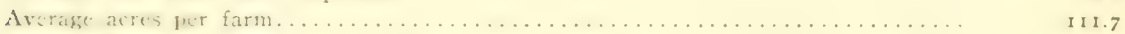

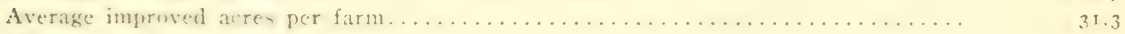

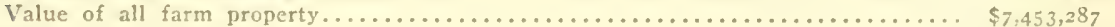

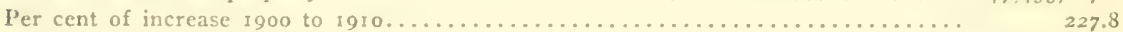

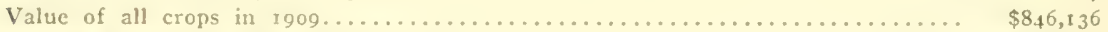

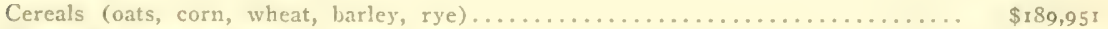

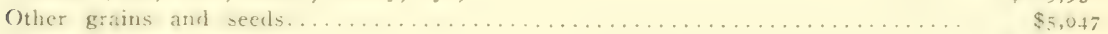

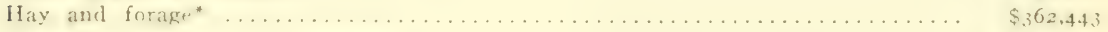

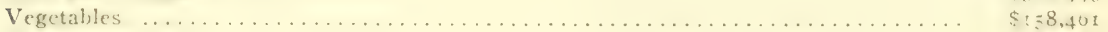

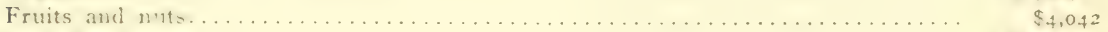

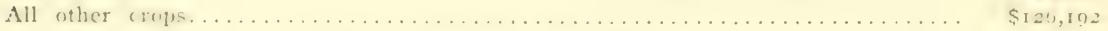

* Tame grass, 32,050 tons; wild grass, 13,356 tons.

\section{SOUTHERN AITKIN COUNTY}

The part of Aitkin County south of the median line of the state was briefly discussed with the main part of the connty lying north of this line. in Bulletin 13. The per cent of swamp land in this part is somewhat less than for the entire county, estimated by Ralph as 42 per cent. The swamps are largely underlain by clayey till similar to that of the border- 
ing dry land, and they can be greatly reduced by systematic ditching. Two sandy areas occur in this part of the county, one being immediately north of Mille Lacs Lake, and the other at the terminus of the Superior lobe in T. 45. R. 24, and T. 45, R. $231 \mathrm{~V}$., with an extension down Snake River into T. 44, R. $23 \mathrm{~W}$.

This part of the county is traversed by a new branch of the Soo Railroad, on which the villages of Arthyde. Sulana, McGrath, and Red Top have sprung up, while farms are being rapidly developed. Iior statistics from the census of I9IO concerning the products of this county, reference may be made to Bulletin I3.

\section{KANABEC COUNTY}

Kanabec County is located in eastern Minnesota with Mora as the comnty seat. The principal settlement and farming development is along or near the lines of the Great Northern Railroad, one of which crosses its southern part and another touches its southwest corner. The surface of the county slopes from north to south, being 1,200 to 1,300 feet in the northern part and about 950 feet in the southern. The prominent moraine of red Patrician drift which crosses the northern part of Mille Lacs County also passes through the northern edge of this county, but elsewhere morainic features are weak and much of the surface is a till plain. There are a few outcrops of rock with slight relief in the northern part of the county, but these are chiefly along or near Snake River.

The Grantsburg lobe of the Keewatin ice field barely touched the southern edge of the county for a few miles west of Braham. A small glacial lake covered much of the southeast township. This lake, however, was apparently held up by the Patrician ice barrier on the north. This lake area was later encroached upon from the south by the Keewatin ice. It has a clay soil.

Another small glacial lake extended into the sonthwest corner of the county from southern Mille Lacs (ounty. This seems to have been held in by the Keewatin ice south of it which covered the lower course of Rum River, the present outlet for this region.

Interglacial valleys cut in the old gray drift which underlie this county have been only partly filled by the later or Wisconsin drift. Lakes and swamps occur along the lines of these partially filled valleys, and gravelly knolls also occur in them. 
Square miles Per cent

\begin{tabular}{|c|c|c|}
\hline Sandy moraine, sandy to stony loam... & 25 & 4.7 \\
\hline 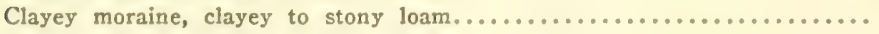 & 55 & 10.3 \\
\hline 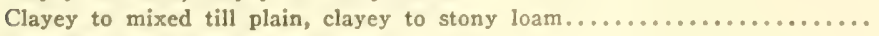 & 346 & 64.8 \\
\hline 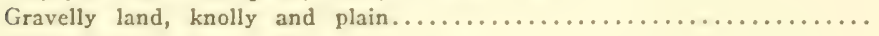 & 20 & 3.7 \\
\hline 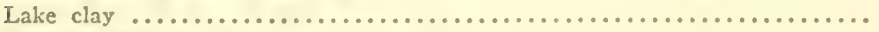 & 20 & 3.7 \\
\hline 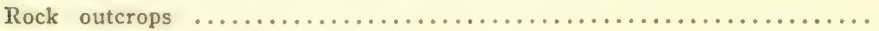 & 3 & 0.5 \\
\hline 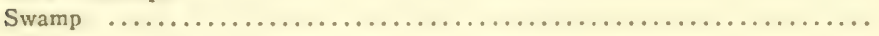 & 65 & 12.3 \\
\hline & 534 & 100.0 \\
\hline
\end{tabular}

Farm and Crop Data for Kanabec County, from Census of 1910

Rural population 5,1 ro or 9.5 per square mile.

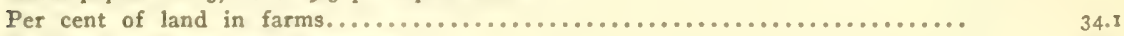

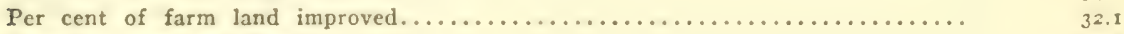

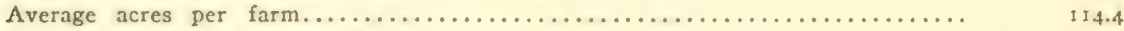

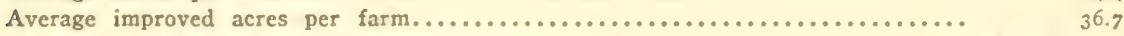

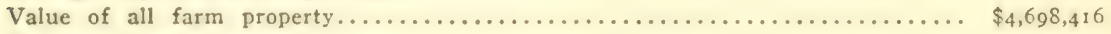

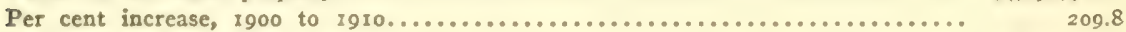

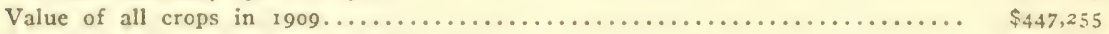

Cereals (oats, corn, wheat, barley, rye) .......................... \$96,036

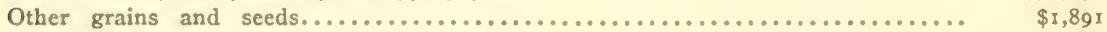

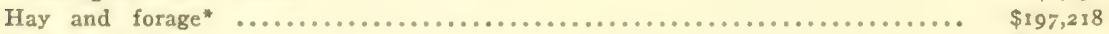

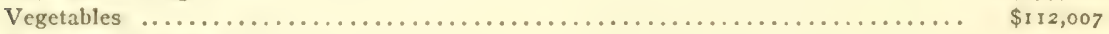

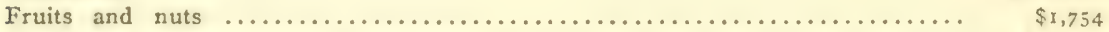

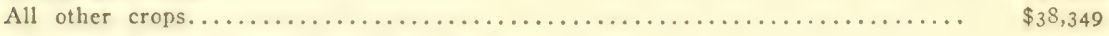

- Tame grass, 19,445 tons; wild grass, 8,644 tons.

\section{MILLE LACS COUNTY}

Mille Lacs County embraces the southern end of Mille Lacs Lake and extends southward about 40 miles beyond the lake in a narrow strip I2 to 18 miles wide. The land area is 583 square miles and the water area II 7 square miles. The percentage of swamp land is about the same as in Kanabec County, or not far from one eighth of the county. The northern part of the county is crossed by a prominent moraine of red Patrician drift, but the remainder is largely till plain of red Patrician drift. A moraine of the Keewatin gray drift is found in the south end of the county. In this southern end there was a small glacial lake immediately north of the Keewatin ice border whose bed is now drained southward by Rum River.

There are a few places where granite ledges are exposed along and near Rum River and its tributaries. They have slight relief above the land around them, and a combined area of not over 2 square miles.

As in Kanabec County the interglacial valleys cut in the old gray drift are only partly filled by the later or Wisconsin drift, and are now occupied to some extent by swamps and lakes. The moraine of red Patrician drift also incloses many lakes and swamps.

The principal settlements and most of the farming development has been along and near the Great Northern Railway lines in the southern 
part of the county, and along the border of Mille Lacs Lake, near the Soo Railway.

Percentages of Classes of Land in Mille Lacs County

Square miles Per cent

\begin{tabular}{|c|c|c|}
\hline Clayey to mixed red drift moraine, stony loam....... & 80 & 13.72 \\
\hline 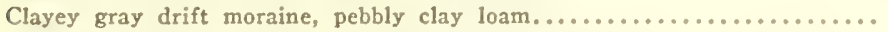 & 5 & 0.86 \\
\hline Clayey to mixed red drift till plain, chiefly stony loam............... & 356 & 61.07 \\
\hline Clayey gray drift till plain, pebbly clay loam.................... & 5 & 0.86 \\
\hline Gravelly and sandy outwash and glacial drainage, sandy to gravelly loam.. & 35 & 6.00 \\
\hline 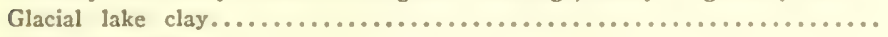 & 20 & 3.43 \\
\hline 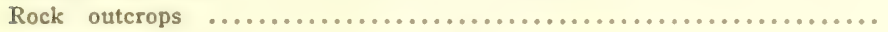 & 2 & 0.34 \\
\hline & 80 & 13.72 \\
\hline & 583 & 100.00 \\
\hline
\end{tabular}

Farm and Crop Data for Mille Lacs County from Census of 7910

Rural population $2,4 \mathrm{II}$ or 4 per square mile.

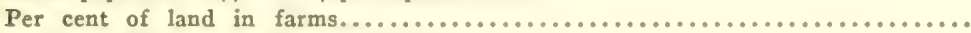

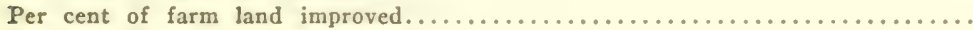

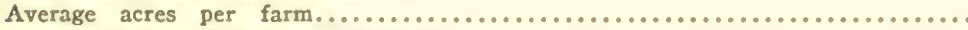

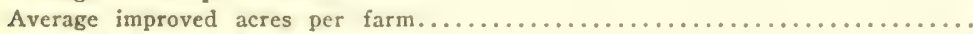

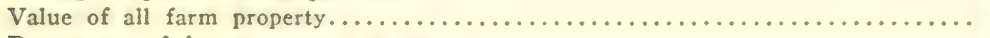

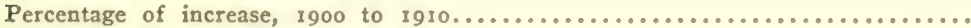

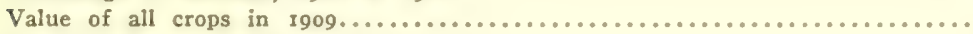

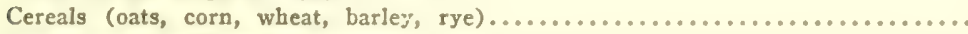

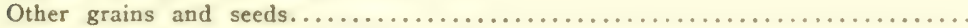

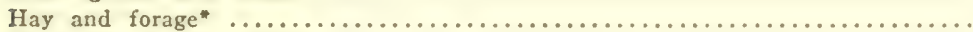

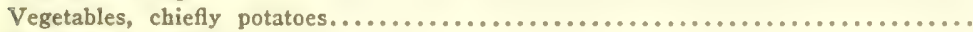

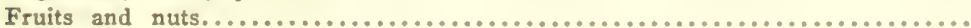

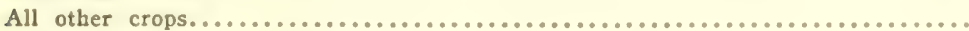

- Tame grass, 28,784 tons; wild grass, 12,904 tons.

\section{SOUTHERN CROW WING COUNTY}

Crow Wing County, of which Brainerd is the county seat, is near the center of the state, and is so situated that part of its area lies in the northeast quarter, part in the northwest quarter, and about 40 per cent in the southern half of the state. Descriptions of the northern part have been given in Bulletins 12 and 13.

Crow Wing County is drained entirely by the Mississippi River which traverses it nearly centrally from northeast to southwest. A large part of the county stands between $I, 200$ and I,300 feet above sea level, there being only a few square miles above 1,300 feet and only narrow strips along the valleys below $\mathrm{I}, 200$ feet. The prominent Mille Lacs moraine traverses the eastern part of the county. West of it, occupying several townships in the southern part of the county, is a till plain with gently undulating surface and rich clayey to sandy loam soil. East of the river above Brainerd there is a diffuse morainic belt. Along and west of the Mississippi River there are sandy and gravelly plains which are very sparsely settled. Fine sand from these plains has drifted to some extent over the till plains immediately south of Brainerd, forming a coating 
from a few inches to several feet thick for a distance of one to three miles east of the valley.

The moraines of the southern part of the county are largely of gravelly and stony drift, while the outwash aprons associated with them are also of light sandy soil.

Of about 400 square miles in this southern part of Crow Wing County, there are I30 square miles of clayey till lying southeast of Brainerd which includes most of the farm land of this part of the county.

\section{SOUTHERN CASS COUNTY}

About I40 square miles of the southern end of Cass County falls south of the median line of the state. The remainder of the county is discussed in Bulletin I2. Of this southern part about 40 square miles are till plain with clayey to stony loam soil. About 25 square miles are rugged moraine with gravelly and loose textured drift. The remaining 75 square miles are occupied by gravelly and sandy outwash plains on the borders of Crow Wing River. The principal settlement is on the till upland, but a few small farms are opened on the plains in the Crow Wing valley along the line of the Northern Pacific Railroad in the vicinity of Sylvan and Pillager stations.

\section{MORRISON COUNTY}

Morrison County is located in the central part of Minnesota with Little Falls as the county seat. The Mississippi River crosses the county from north to south a little west of the center and Crow Wing River forms part of its north border. There is a broad belt of sandy land along the Mississippi, formed as a glacial drainage from districts farther north. There is another plain of sandy gravel with a somewhat more loamy soil which lies a few miles east of the Mississippi River in the southern part of the county. There is also a sandy plain along Crow Wing River. The greater part of the county is a till plain which is encircled on the west by a prominent red drift moraine which occupies the northwestern part of this county and the eastern part of Todd County. This moraine is very complex and has small outwash aprons, as well as lakes and swamps enclosed among its ridges and knolls. Owing to the roughness of the surface and the stony character of the drift, this moraine has remained largely undeveloped, while the neighboring till plains have become more fully settled. The till plains of the eastern part of the county, however, are only partly settled, but this is due largely to the lack of railroad facilities prior to the recent construction of a branch of the Soo Line Railroad across the southeast part of the county. 
The till plains of this county, like those of Mille Lacs and Kanabec counties, have so thin a coating of the Wisconsin red drift that the interglacial valleys cut in the old gray drift are only partly filled, and exposures of the old gray drift beneath the red drift are not rare along the streams and bluffs.

The percentage of swamp land in this county is very much smaller than in counties to the north and east, there being, as estimated by Ralph, only 20,000 acres or $3 \mathrm{I}$ square miles, which is but 2.7 per cent of the county.

Rock outcrops are not extensive though exposures are not infrequent. There is probably an area of less than Io square miles in which the rock is close to the surface.

Several sharp gravel ridges, or eskers, are found on the till plain or leading into the edge of the moraines. One such ridge leads past Darling Station along or near the Northern P'acific Railroad, northwest of Little Falls, for a distance of about 7 miles. It has been extensively drawn upon for railroad ballast. Another gravel ridge southeast of Fort Ripley, on the east side of the Mississippi, is 5 or 6 miles long, and a shorter one is found two miles farther south near Topeka. There is also a short gravel ridge south of Motley in the northwest part of the county. All such ridges are of much value in furnishing road material, especially when located in till plains.

Fine sand blown from the outwash and river gravels along the Mississippi extends the sandy soil areas eastward even onto the upland. Such a dune-sand tract lies southeast of Fort Ripley, a larger one east of Royalton, and a small area at Little Falls.

\section{Percentages of Classes of Land in Morrison County}

\begin{tabular}{|c|c|c|}
\hline & Square miles & Per cent \\
\hline 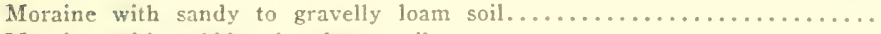 & 175 & I5.31 \\
\hline 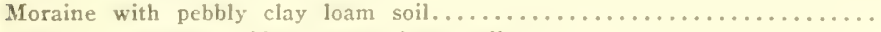 & 70 & 6. 12 \\
\hline 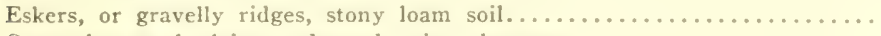 & 2 & 0.18 \\
\hline 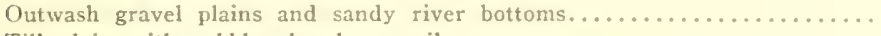 & 180 & 15.75 \\
\hline 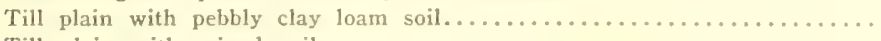 & 500 & 43.75 \\
\hline 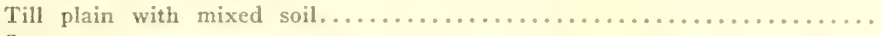 & 170 & 14.87 \\
\hline 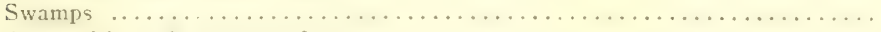 & $3^{6}$ & 3. 15 \\
\hline 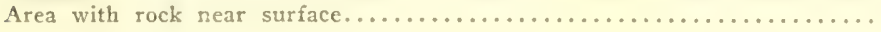 & 10 & 0.87 \\
\hline & $I, 143$ & 100. \\
\hline
\end{tabular}

Farm and Crop Data for Morrison County from Census of 1910

Rural population 15,433 or 13 per square mile.

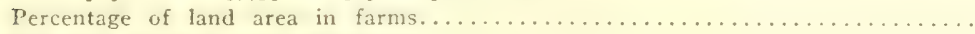

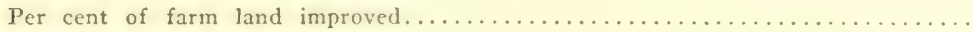

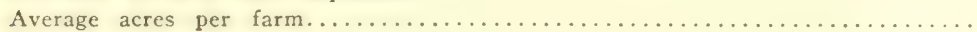

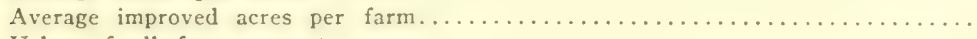

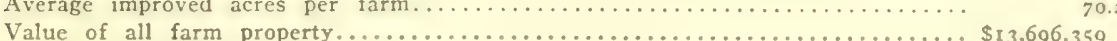

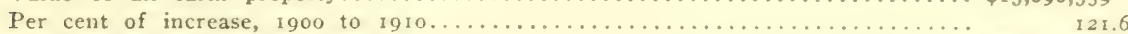

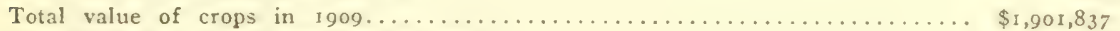

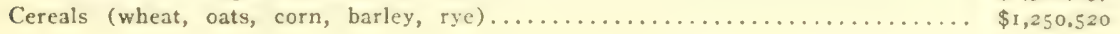


Farm and Crop Data for Morrison County (Continued)

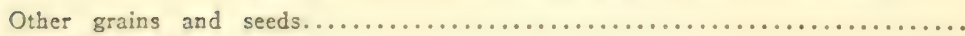

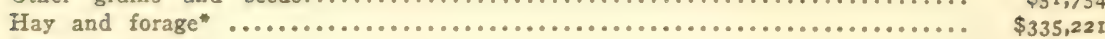

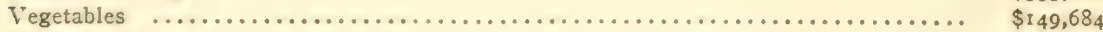

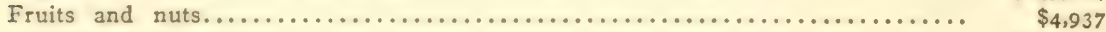

All other crops............................................ \$109,757

* Tame grass, 31,746 tons; wild grass, 45,667. Each yielded about 1.5 tons per acre.

TODD COUNTY

Todd County is located in the west central part of Minnesota with Long Prairie as the county seat. The drainage of about two thirds of the county is northward to Crow Wing River, chiefly through Long Prairie River. The southern end of the county is drained southward to Sauk River, and part of the eastern edge is drained eastward to the Mississippi chiefly by Swan River. Hardwood forest occupied the south part, and mixed hardwood and conifers the north part. There were small prairies on gravel plains near Long Prairie and Round Prairie.

The most prominent topographic feature is a strong and sharply ridged red drift morainic system in the east part of the county. It covers a width of 3 to 6 miles, and contains ridges 50 to 75 feet or more in height as well as numerous basins and small lakes. This morainic system is very sparsely settled in comparison with the remainder of the county.

The Keewatin ice field apparently had its eastern limit along or near the west base of this prominent morainic system, but its drift is thin in this county and generally plain. It includes a sharp morainic ridge running from Long Prairie southwestward to Osakis Lake, which is scarcely one fourth mile in average width, but rises 50 to 75 feet or more above the bordering plains.

The till plains of this county have a relatively thin veneer of young or Wisconsin drift over a much eroded surface of old gray drift. The present drainage lines, therefore, usually follow broad swales marking the courses of interglacial streams. The sandy outwash plains and lines of glacial drainage also occupy or follow the courses of interglacial drainage to some extent.

A red drift till plain lies between two red drift moraines in the southeast part of the county in the vicinity of Gray Eagle. A till plain on the east of the main moraine extends slightly into Todd County, but lies mainly in Morrison County. These till plains are largely under cultivation. The soil is usually a clayey to stony loam.

Attention is directed in the introductory chapter to the peculiar mixture of red drift rocks and gray drift in a belt immediately west of the prominent moraine. This is a loose textured, rather stony till, yet it has a sufficient amount of clay to be very productive.

The amount of swamp land or land too wet to cultivate is estimated by Ralph to be 25,000 acres, or about 40 square miles, which is slightly 
more than 4 per cent of the area of the county. Nuch of this is in sandy plains in the northeast corner and in the western edge of the county. But some of the swales in the till area where the interglacial valleys are imperfectly filled by the Wisconsin drift have strips of wet land. There are also small swamps inclosed among the morainic knolls and ridges.

\section{Per Cent of Classes of Land in Todd County}

Square miles Per cent

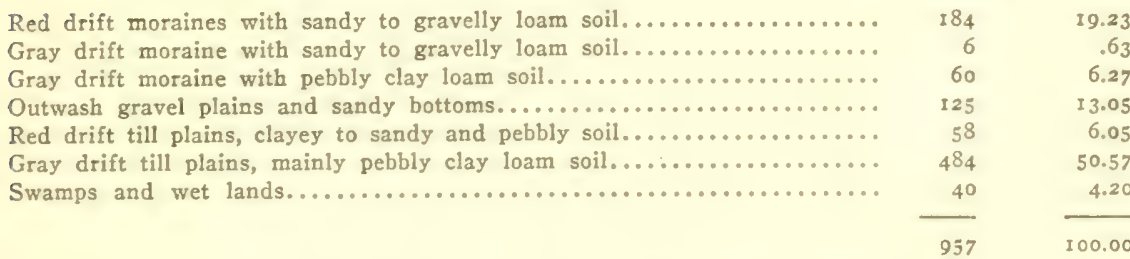

Farm and Crop Data for Todd County from Census of Igro

Rural population 16,588 or 17.3 per square mile

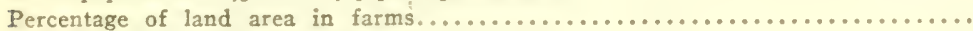

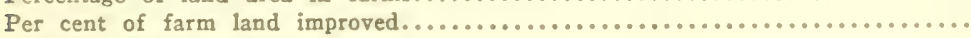

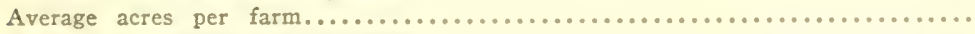

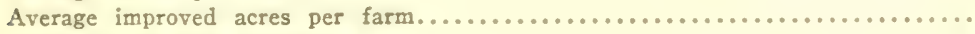

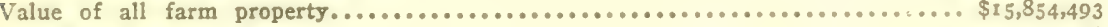

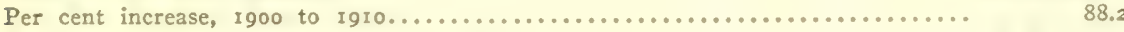

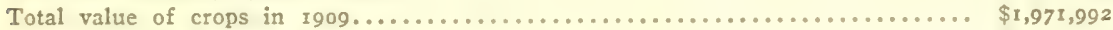

Cereals produced (oats, wheat, corn, barley, rye)................... $\$ 1,223,557$

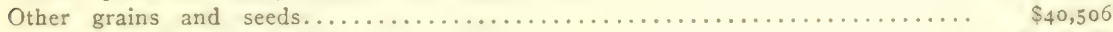

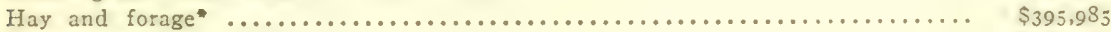

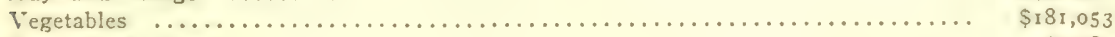

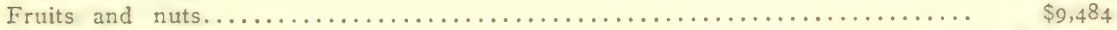

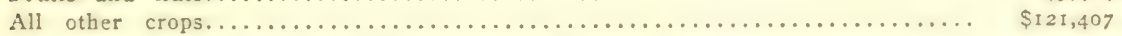

- There were $4 \mathrm{r}, 864$ tons of cultivated and 48,397 tons of wild grasses cut. The cultivated grasses yielded about 1.7 tons per acre and the wild grasses 1.4 tons.

\section{SOUTHERN OTTER TAIL COUNTY}

Otter Tail County is located in the western part of Minnesota with Fergus Falls as the county seat. It has a land area of over 2,000 square miles not including 200 square miles of lake area. The northern part of the county embracing 35 townships, or an area of about 1,260 square miles, was described in Bulletin 12. There remain 27 townships, or about 972 square miles in the southern part to be here discussed.

The entire area is settled about as fully as is consistent with profitable agriculture under present methods. There is a large amount of rough moraine with included bogs and lakes that is now in woodland pasture. In the prairie portion, which embraces a few townships in the southwest part of the county, nearly all of the land that is dry enough has been brought under cultivation.

The greater part of the southern half of Otter Tail County is drained westward through Otter Tail River and its branches to the Red River valley. The eastern part is drained northeastward into Crow Wing 
River and thence into the Mississippi. Lakes are a conspicuous feature in nearly every township, but are very small in the western range of townships.

The most prominent topographic feature is the intricate system of moraines which was formed on the east side of the Keewatin ice field, as noted in the general discussion of the features of that ice field. There are only narrow strips of till plain in the county. The total area of till plain in the three southern tiers of townships is estimated to be 160 square miles, or 16.5 per cent of the area. The greater parts of the moraines of this county have a sandy to gravelly loam soil, but those in the western part in the prairie portion of the county have a clay loam soil.

About 50 square miles along the western edge of the county were covered by the waters of the glacial Lake Agassiz. The surface here is very flat and the soil is largely a silty loam or fine sand. The shore lines of the lake are of fine gravel suitable for road ballast.

There are two very extensive outwash plains, each with an area of several townships, associated with the moraines in this county. One in the eastern part, known as the Parkers Prairie Plain, has an altitude of I,450 to I,500 feet, and slopes northeastward to Crow Wing River. It is an outwash from a prominent moraine, known as the Leaf Hills, which runs along its. western border, and from which a very prominent spur, known as Leaf Mountain, extends southwestward to Christina Lake.

To the west of the Leaf Hills there is a narrow till plain succeeded by another extensive outwash plain which surrounds Otter Tail and Battle lakes and which was formed as an outwash from the great morainic system lying west of it. These outwash plains have a rather light sandy loam soil, but they were among the earliest areas in the county to be farmed, and are still yielding good returns under skillful management.

\section{DOUGLAS COUNTY}

Douglas County is situated in western Minnesota with Alexandria as the county seat. Its land area is 648 square miles, and its lakes, which are very 11 monerous, are estimated to occupy 72 square miles. The eastern part of the county is drained northeastward through Long Prairie River to Crow Wing and thence to the Mississippi; but the remainder of the county slopes southwestward and drains in that direction to the Chippewa, which flows southward into Minnesota River. The greater part of this county was timbered with hardwood, but prairie extended into its western edge.

The western half of the county is very largely occupied by a prominent morainic system which formed along the east side of the Keewatin ice sheet. There are extensive outwash plains of sandy gravel along the 
eastern edge of this morainic system. Farther cast there are till plains which extend into Todd County. These, as well as the morainic system, have a sheet of young gray drift formed by the Keewatin ice field.

The morainic areas as well as the till plains are largely under cultivation, and they are chiefly of clayey till with pebbly clay loam soil. The gravel plains have a light sandy loam soil. They are largely under cultivation, and except in very dry seasons have a good yield of cereals.

Percentages of Classes of Land in Douglas County

Square miles Per cent

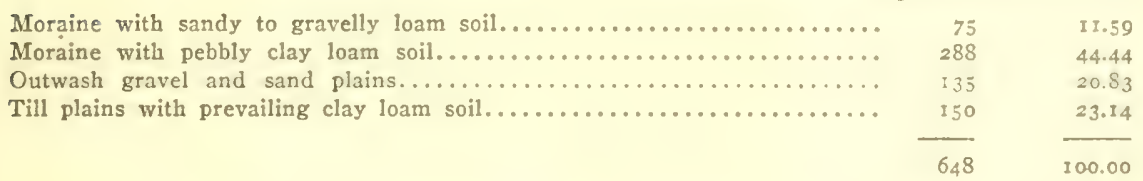

Farm and Crop Data for Douglas County from Census of Igro

Rural population 12,165 or 18.8 per square mile

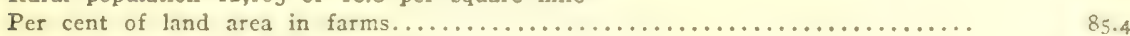

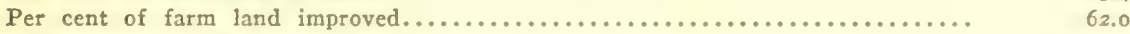

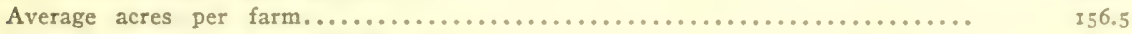

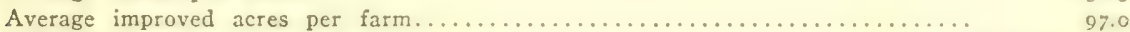

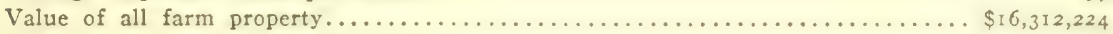

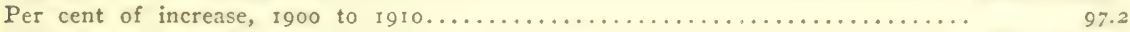

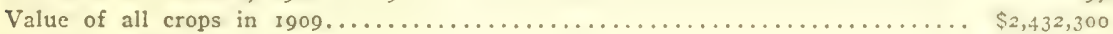

Cereals (wheat, oats, barley, corn, rye)...................... $\$ 1,175,703$

Other grains and seeds..................................... $\$ 97,751$

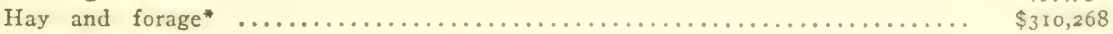

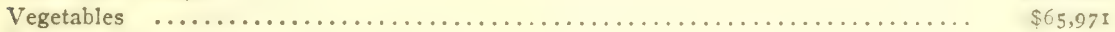

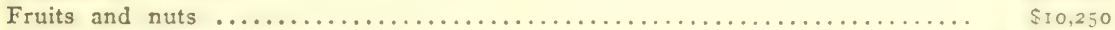

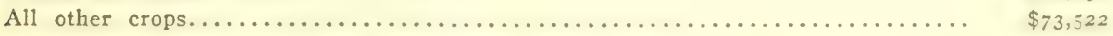

- Tame grass, 38,775 tons; wild grass, 43,831 tons.

\section{GRANT COUNTY}

Grant County is situated in the western part of Minnesota with Elbow Lake as the county seat. This is a prairie county with only narrow fringes of timber along lakes and streams. The eastern part of the county is drained southward through the Pomme de Terre and Chippewa rivers to the Minnesota. The western part is drained westward through Mustinka River to Lake Traverse, and thence northward by Red River to Hudson Bay.

About 128 square miles in the western part of the county were covered by the waters of the glacial Lake Agassiz. The remainder of the county is largely a till plain of young gray drift. The eastern edge is strongly morainic, and there are narrow moraines of feeble expression leading north to south across the county. Narrow strips of gravelly and sandy land border the Chippewa, the Pomme de Terre, and the south flowing part of the Mustinka rivers, which appear to mark lines of glacial drainage. Several of the higher lakes of this county have been drained by deep ditching and their beds converted into farm land. Several others 
of the lakes are in the bottom of valleys that appear to be partially filled interglacial valleys. Some partly filled valleys are without streams, and these present a rougher topography than the bordering upland, with some likeness to morainic topography, but this topography seems to have been developed locally because of irregularity of the ice movement in its passage across the valleys.

\section{Percentages of Classes of Land in Grant County}

\begin{tabular}{|c|c|}
\hline & Square miles \\
\hline 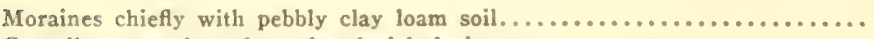 & 100 \\
\hline 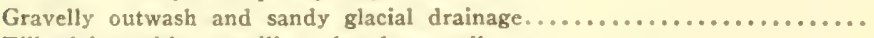 & 35 \\
\hline 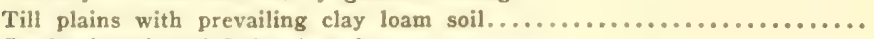 & 290 \\
\hline 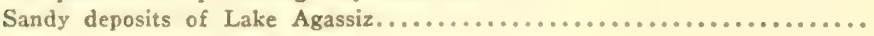 & 28 \\
\hline 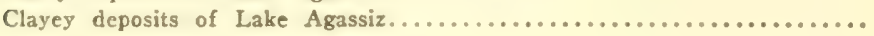 & 100 \\
\hline
\end{tabular}

Farm and Crop Data for Grant County from Census of 1910

Kural population 6,379 or 11.4 per square mile

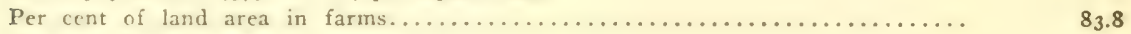

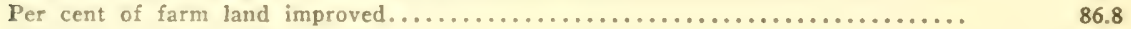

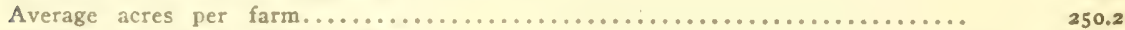

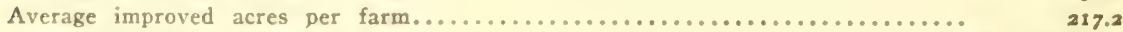

Value of all farm property................................. \$13,482,322

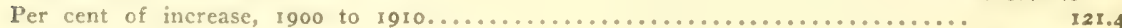

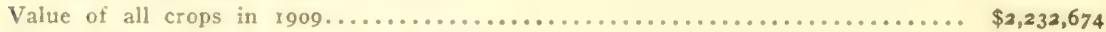

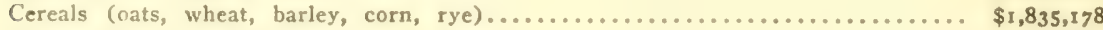

Other grains and seeds................................... \$167,687

Hay and forage* ....................................... $\$$ \$198,88z

Vegetables ................................................ \$23,424

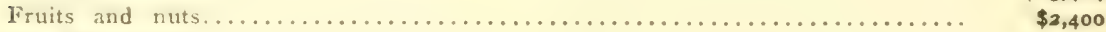

All other crups............................................ \$5,104

- 'Tame grass, 23,99 I tons; wild grass, 28,738 tons.

\section{WILKIN COUNTY}

Wilkin County is on the western edge of Minnesota with Breckenridge as its county seat, and has an area of 745 square miles. With the exception of about 50 square miles in the northeast part it was covered by the waters of Lake Agassiz. Its surface is consequently level and nearly featureless. There is, however, a fall of over 300 feet in crossing the county from east to west along the northern line in a distance of about 25 miles. In the southern end of the county the fall is about 50 feet in a distance of 15 miles. The county had few natural lines of drainage, but side ditches follow nearly all the highways and receive water from tile drains on the farms and carry it to natural drainage lines. Otter Tail River and Rabbit Creek run across the southern part of the county and Deerhorn Creek its northeast corner, while Bois des Sioux and Red River flow on the west border.

The percentages of classes of land in the northern part of the county have been given in Bulletin 12. In that part of the county there are 50 square miles of clayey moraine and till plain, with pebbly clay loam soil, 
standing above the level of Lake Agassiz. But in the part south of the median line of the state only about 2 square miles of till plains stood above the lake limits. In the northern part there are about i6o square miles of lake-washed drift with pebbly soil and but a slight cover of lake silt, and about 90 square miles covered by lake sand. There thus remain only 7o square miles of that part with sufficiently heavy deposits of lake silt to make a black clay loam soil. In the southern part of the county the lake silt and black clay loam soil form a strip several miles wide bordering Red River and the Bois des Sioux. As one passes eastward the silt thins out gradually, so that clayey till is at the surface, or within reach of the plow, in the eastern part of the county. The soil is somewhat sandy near Foxhome and east of Nashua, but grades into clay loam at the west.

The shore lines of Lake Agassiz are usually gravelly ridges which furnish good building sites and roadways, and were thus used extensively in the early days of settlement. These shore lines, though running for long distances, have an aggregate area of but a few square miles, probably less than I per cent of the county.

The census for 1910 reports about 44 square miles of wild grass cut in I909. This grass was in areas that were still too wet for cultivation. There is probably not more than Ioo square miles of poorly drained land remaining in the county, and part of this can be reclaimed by systematic ditching.

Farm and Crop Data for Wilkin County from Census of 5910

Rural population 5,585 or 7.5 per square mile

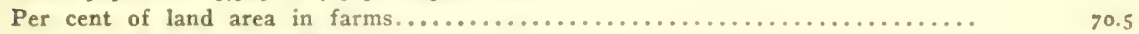

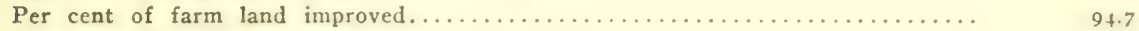

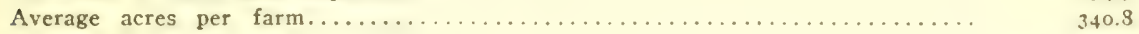

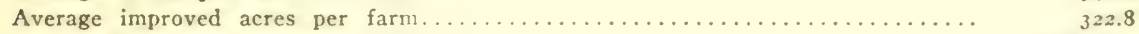

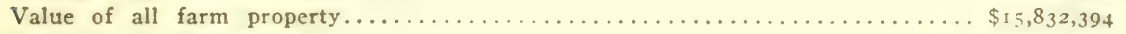

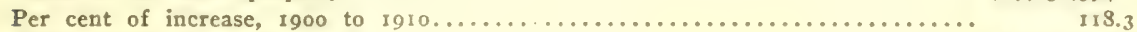

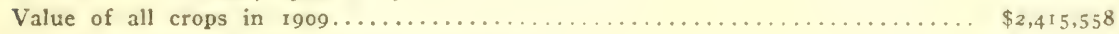

Cereals produced in 1909 (wheat, oats, barley, corn, rye)............. \$2,010,119

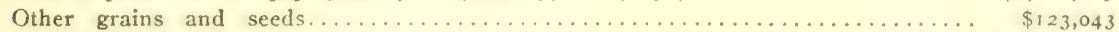

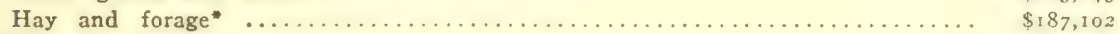

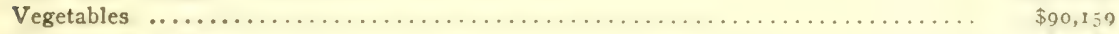

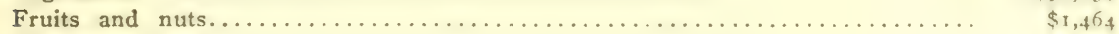

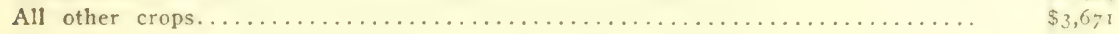

- Tame grass, 16,64 I tons; wild grass, 25,733 tons.

\section{TRAVERSE COUNTY}

Traverse County is situated on the western border of the state with Wheaton as its county seat. It is a prairie county and there is very little land that is not under cultivation. Such land, however, is found along the bluffs and ravines on the borders of Lake Traverse which are too rough to cultivate. There are also several miles of swamp land in the northeast part of the county along the Mustinka valley and between that valley and Tintah which are being reclaimed by ditching. The drainage 
is nearly all northward to the Red River valley. MIustinka River and its tributaries ranify the eastern part, while Lake Traverse and Bois des Sioux River discharge along the west border to Red River. A few square miles in the southwest corner are tributary to Big Stone Lake and Minnesota River.

Only the southern end of the county stood above the level of Lake Agassiz, and this is occupied by a till plain except two narrow morainic strips which cross the area between Lake Traverse and the south end of the Lake Agassiz area. The western of these moraines has many small knolls and a diversified soil, but the eastern one has a gently undulating surface and a somewhat uniform pebbly clay loam soil similar to that of the bordering till plain.

This county embraces the head of the outlet of Lake Agassiz, and there are channels cut in the bed at the lower levels of the lake along the entire west side of the county and also along the southwest flowing portion of Mustinka River, but in the higher stages the lake opened directly into the large valley now occupied by Lake Traverse. The highest limits of Lake Agassiz waters were I,065 to I,070 feet, but the outlet was cut down to about 970 feet during subsequent southward discharge of the lake.

There are very bowldery areas in central and northwestern Traverse County within the limits of the Lake Agassiz. The bowlders were probably dropped in part directly from the shrinking ice border. The erosion of the channels above noted may also have tended to concentrate them.

At the extreme southern end of the Lake Agassiz area in T. 126, Rs. 45 and $46 \mathrm{~W}$., and the southeast part of T. $127, \mathrm{R} .45 \mathrm{~W}$., there is a coating of fine sandy loam nearly free from pebbles with a depth of 2 to 5 feet, so the till there is seldom exposed. But elsewhere in the county the till in the lake bed is very scantily covered with lake sediment. The northern end of the county has a black clay loam soil, but even there a pebbly clay or till is found at a depth of a few inches.

The shore lines of Lake Agassiz are composed of sandy gravel. There are also gravel bars and small areas of sandy gravel on a high tract between the low channels of the lake crossed by the Milwaukee and St. Paul Railroad just before it passes into South Dakota. Some of these gravel bars are at the level of the Norcross beach, and others at the level of the Tintah beach. The main shore of the Tintah beach follows the east side of the southwest flowing portion of the Mustinka River. 
Percentages of Classes of Land in Traverse County

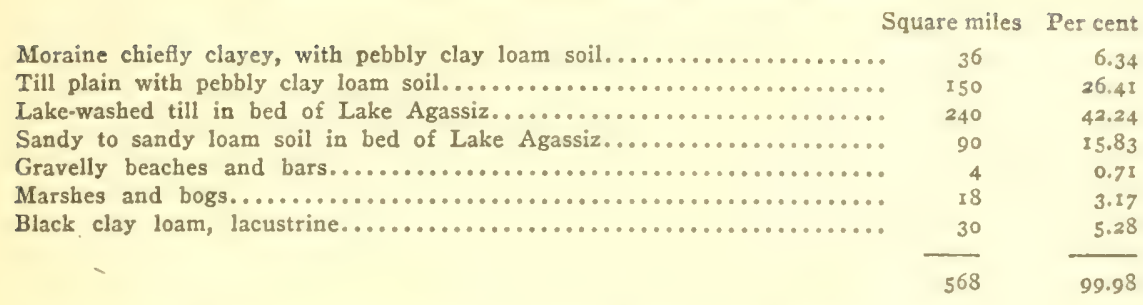

Farm and Crop Data for Traverse County from Census of 1910

Rural population 5,286 or 9 per square mile

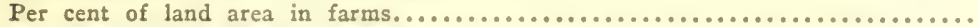

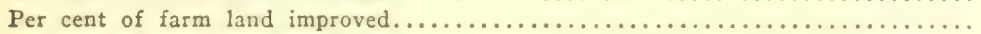

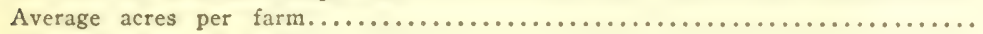

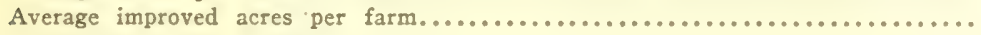

Value of all farm property................................... \$16,296,339

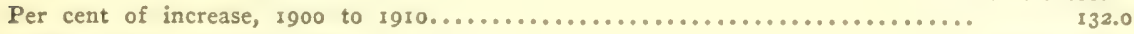

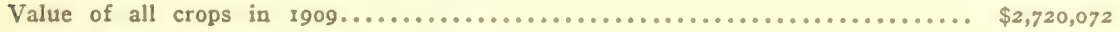

Cereals (wheat, oats, barley, corn, rye).......................... \$2,333,966

Other grains and seeds...................................... \$171,316

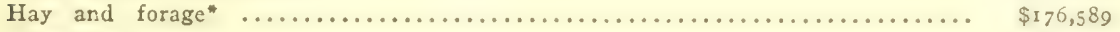

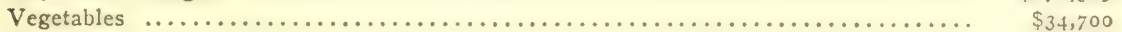

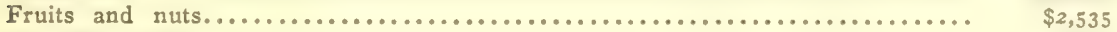

All other crops.................................................

* Tame grass, 21,163 tons; wild grass, 20,681 tons.

\section{BIG STONE COUNTY}

Big Stone County is situated on the western border of the state, with Ortonville as the county seat, and has an area of $49 \mathrm{I}$ square miles. The drainage is mainly to the Minnesota River, but the northeast corner drains northward to Mustinka River and the Red River of the North. The natural drainage lines are very imperfect and large ditches have been carried along highways to connect with the natural drainage lines. The dividing ridge in the northeast part of the county is I,I70 to I,ISO feet, or fully Ioo feet above the highest shore of Lake Agassiz and over 200 feet above Big Stone Lake. It has the appearance of an overridden moraine, for there are numerous basins and swales along it; but the prominent parts have a smooth surface of clayey calcareous till like that of the till plains of this region.

The greater part of Big Stone County is a till plain with pebbly clay loam soil. It is thickly set with small lakes and basins, estimated to occupy about Io per cent of the surface. There is a morainic belt in the northwest part of the county leading southward past Beardsley to Big Stone Lake. It follows the south side of that lake in South Dakota, but comes back into Minnesota at the southeast end of the lake and traverses the south part of Big Stone County, making a detour northward around the head of a sandy outwash plain east of Odessa. There is an outwash plain along much of its border, both in northwestern and in southern Big 
Stone County. The outwash plains stand 50 to 75 feet above the broad bottoms of the Minnesota valley. In places there are islands in the valley with the outwash preserved on them, one of which is to be seen in the village of Odessa, and others farther east.

In the Minnesota valley there are ledges of granite occupying perhaps Io per cent of its bottoms, around which granite bowlders are numerous over large areas. A considerable part of the valley is also too wet for cultivation.

The soil on the moraines is a loose textured clayey to gravelly loam, and occasional gravel linolts are present. The outwash plains have a rather light sandy soil.

Percentages of Classes of Land in Big Stone County

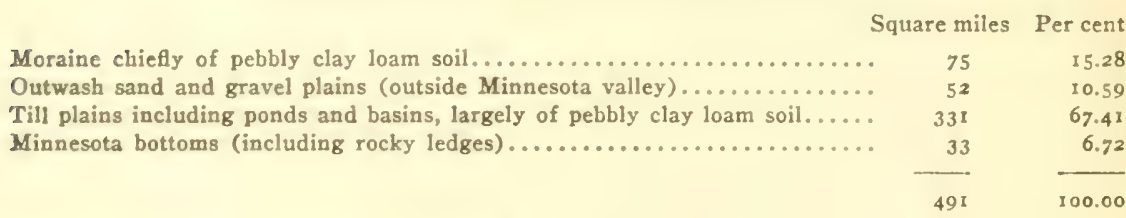

Farm and Crop Data for Big Stone County from Census of 1910

Rural population 5,165 or 10.5 per square mile

Per cent of land area in farms..................................... 90.0

Per cent of farm land improved................................... 85.8

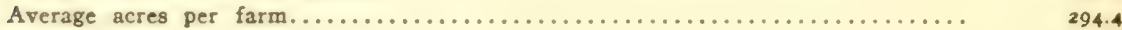

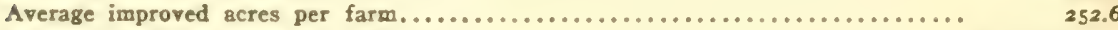

Value of all farm property.................................... $\$ 14,262,257$

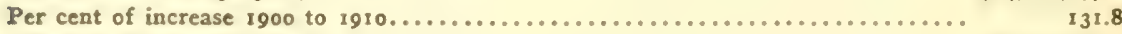

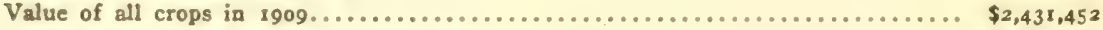

Cereals (whest, oats, barley, corn, rye).......................... \$2,074,389

Other grains and seeds........................................ \$151,276

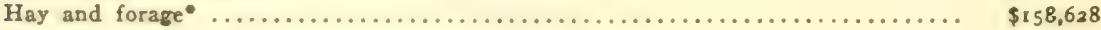

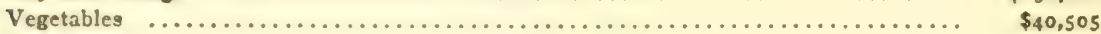

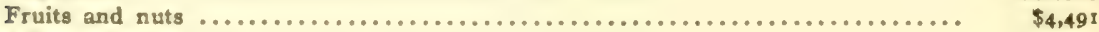

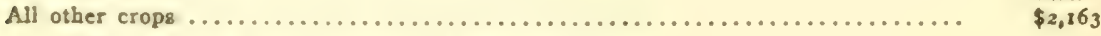

- Tame grass, 18,694 tons; wild grass, 34,221 tons.

\section{STEVENS COUNTY}

Stevens County lies east of Big Stone and Traverse counties in the western part of the state, with Morris as the county seat. It has a land area of 564 square miles, while small lakes give an additional area of about I2 square miles. The drainage is mainly southward through Pomme de Terre and Chippewa rivers to the Minnesota, but the northwest corner of the county drains northwestward to the Red River drainage.

Pomme de Terre River leads through several lakes. There are also lakes on the uplands each side and in partially filled interglacial valleys. Those on the uplands have in some cases been completely drained by deep ditching, and their beds converted into farm land. 
The greater part of the county is a plain of clayey till with black clay loam soil. The surface is somewhat rougher and the character of the soil more variable in some filled interglacial valleys than on the higher and smoother tracts above them.

There is a moraine along part of the east edge of the county. There are also other lines of knolly land suggesting later ice borders in the interior of the county. Strips of gravelly land, formed by glacial drainage, occur along Pomme de Terre and Chippewa valleys, and a sandy plain of considerable extent spreads from southeastern Stevens County east and south into Pope and Swift counties.

A few square miles in the northwest part of the county were covered by Lake Agassiz, and the soil there is sandy with gravelly strips along the shores.

Just outside the limits of Lake Agassiz, there is a narrow strip extending back about to the I,IO0 foot contour, which carries a thin deposit of fine sand and silt. This appears to be due to a ponding of the waters along the edge of the ice while it was occupying the low land later covered by Lake Agassiz. Elsewhere in the county the till plains are not covered with such silt, but have a pebbly clay loam soil, much of it of dark color.

Percentages of Classes of Land in Stevens County

Square miles Per cent

Moraine chiefly of pebbly clay loam soil....................... $30 \quad 5.32$

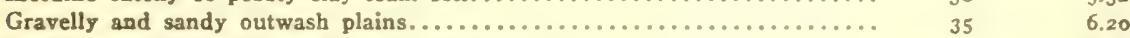

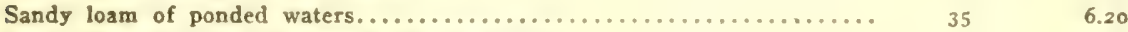

Sand and gravel of Lake Agassiz shores and bed.................. 4.71

Till plain chiefly of pebbly clay loam soil...................... $460 \quad 81.56$

56499.99

Farm and Crop Data for Stevens County from Census of 1910

Rural population 5,480 or 9.7 per square mile

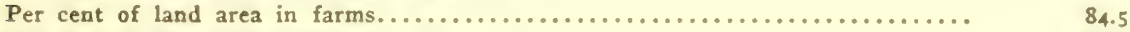

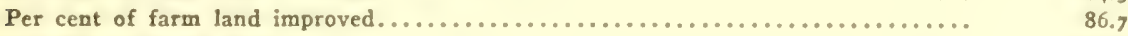

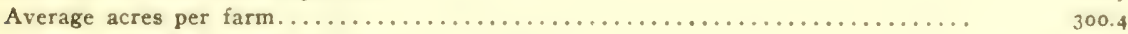

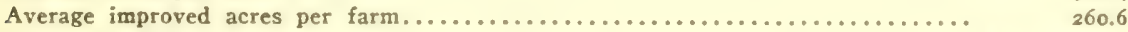

Value of all farm property.................................... \$1374,191

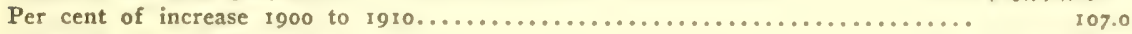

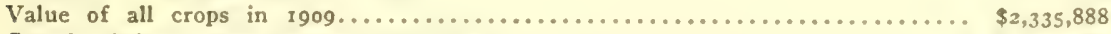

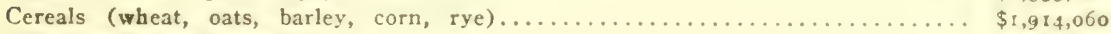

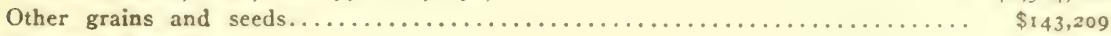

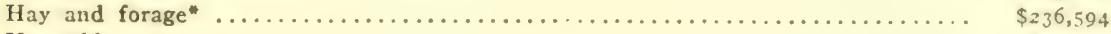

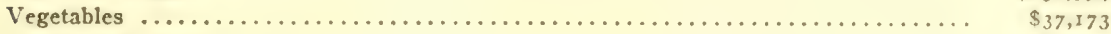

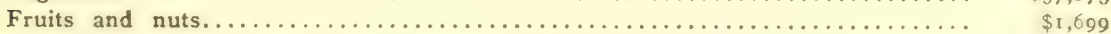

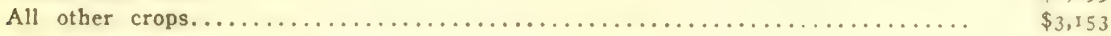

* Tame grass, 27,353 tons; wild grass, 27,959 tons.

POPE COUNTY

Pope County is located in the west central part of the state, with Glenwood as the county seat. It embraces 20 townships or about $\rceil^{20}$ 
square miles, of which 27 square miles are in lakes, leaving a land area of 693 square miles. Lake Minnewaska, on the shores of which Glenwood stands, covers an area of about I 3 square miles.

The drainage is nearly all southward and southwestward through Chippewa River and its tributaries to the Minnesota; but the eastern edge of the county is drained eastward, partly by Sauk River and partly by Crow River to the Mississippi.

In Pope County the great morainic system formed on the east side of the Keewatin ice field turns from a southward to an eastward course, and a very extensive outwash apron occupies this angle outside the morainic system. It covers several townships in the east part of Pope County, and in southwestern Stearns and northern Kandiyohi counties. This outwash plain is very elevated, its highest part being above I,400 feet, and it slopes northeastward to about I,300 feet at its eastern edge. Only a small part of the great morainic system is as elevated as this outwash area. In the western part of the county there is a moraine which follows down Chippewa valley, and this has an outwash plain covering the southwest part of the county, which stands I,050 to I,I00 feet. A narrow till plain in western Pope County lies between this moraine and the large morainic system to the east. There is also a till plain east of the great outwash plain in the northeast part of Pope County.

There is some rough land in the morainic areas with very stony soil, and the drift is loose textured and gravelly for a short distance next to the outwash plain. But a large part of the great morainic system has a pebbly clay loam soil. The till plains have a somewhat uniform pebbly clay loam soil. The outwash plains of eastern Pope County have a light sandy soil, but there are bnggy depressions of considerable extent scattered over it which contain muck and peat. The sandy plain of the southwest corner of the county has a light soil, and it also is traversed by boggy depressions with mucky soil.

Percentages of Classes of Land in Pope County

\begin{tabular}{|c|c|c|}
\hline & Square miles & Per cent \\
\hline oraine, chiefly of pebbly clay loam soil, with included boggy la & 300 & 43.2 \\
\hline 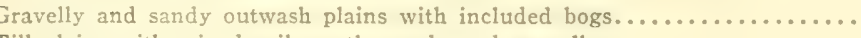 & 200 & 28.8 \\
\hline 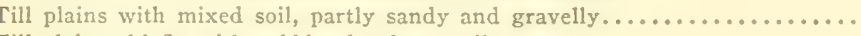 & 38 & 5.4 \\
\hline 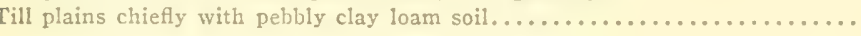 & 155 & 22.3 \\
\hline & 693 & \\
\hline
\end{tabular}

Farm and Crop Data for Pope County from Census of Ioro

Rural population 9,157 or 14.65 per square mile

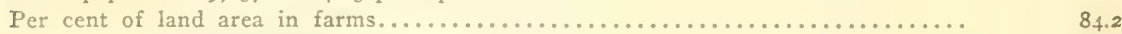

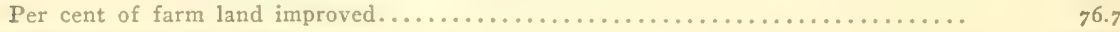

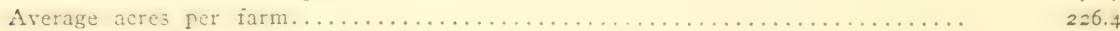

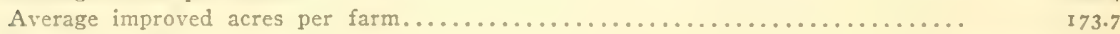

Value of all farm property.................................. \$15,479,163

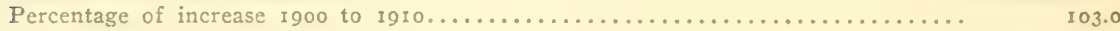


Farm and Crop Data for Pope Connty (Continued)

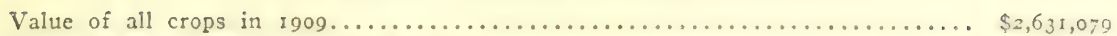

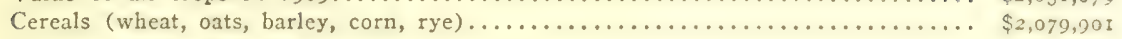

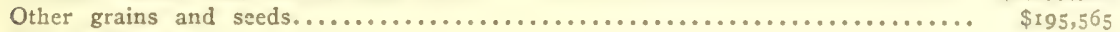

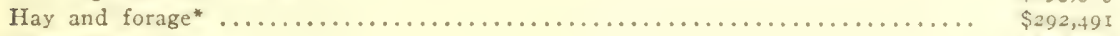

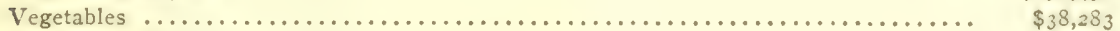

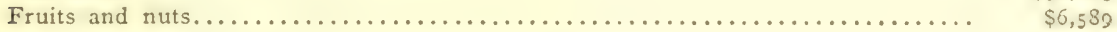

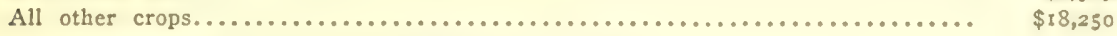

* Tame grass, 33,219 tons; wild grass, 46,050 tons.

\section{STEARNS COUNTY}

Stearns County is located in the south central part of the state, with St. Cloud as the county seat. The entire county drains eastward to the Mississippi which forms its eastern boundary. Sauk River is the main drainage line within the county, but the southwest part is drained by Crow River, and the southeast and the northeast parts by smaller drainage lines directly tributary to the Mississippi.

The eastern part of the county has a prominent morainic system of the Patrician red drift, as well as till plains and outwash plains of red drift. But the central and western parts are covered by the Keewatin gray drift which overlaps the western edge of the red drift. The gray drift also covers the southern edge of the county clear out to the Mississippi. Its border crosses that stream 6 or 7 miles below St. Cloud. Lines of glacial drainage from the gray drift carried gravel containing much limestone down to the Mississippi through areas of red drift in the southeast part of the county and spread it as far north as St. Joseph and St. Cloud. At that time there was eastward drainage along the north side of the Grantsburg lobe from the Mississippi to the St. Croix River.

The gray drift in northwestern Stearns County has an attenuated edge that extends several miles east of the first well defined moraine. This moraine follows Sauk River valley from Sauk Center to New MIunich on the south side of the stream and then crosses to the north side and runs eastward to Cold Spring. There is another till plain on the southwest side of this moraine, extending to the great gravel plain formed along the outer edge of the strong morainic system in Pope County. The outer member of that morainic system comes into the southern part of Stearns County near Paynesville, and runs northeastward nearly to Cold Spring and then turns southward, and passes into Meeker County south of Kimball.

The red drift area, and the east part of the gray drift in this county were covered by forest, but the southwest part of the county was prairie except some brushy land on the gravel plain.

There are numerous small outcrops of granite in the eastern part of the county along the Mississippi and the Sauk River valleys, and also in the northwest part at Melrose and at Sauk Center. The largest area is in western St. Cloud Township, where it is at or near the surface over 
several square miles. The combined areas of outcrops in the county are estimated, however, to be not more than Io square miles, and part of this has soil enough to be farm land.

The area of wet land is estimated by Ralph to be 62 square miles. This apparently includes the lakes as well as swamps and peat bogs. Some of the lakes are shallow enough to be drained by deep ditching.

The moraines of red drift are in places so rough and stony that they are still in forest. There is, however, a considerable part of the red drift with only a moderate number of bowlders and cobble stones. The red drift till plains are largely cleared and farmed. The gray drift area, both in moraines and till plains, is of high fertility, much of it being a pebbly clay loam. The outwash plains both of gray drift and red have a light soil but are extensively cultivated.

Percentages of Classes of Land in Stearns County

Square miles Percent

Gravelly red drift moraine, sandy and stony loam............... II5 8.44

Clayey red drift moraine, pebbly clay loam.................... $55 \quad 4.03$

Red drift till plain, chiefly pebbly clay loam.................... $\quad$ 120 $\quad 8.81$

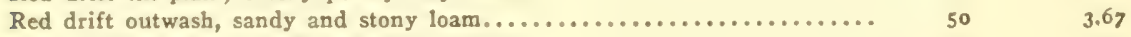

Gray drift moraine, chiefly pebbly clay loam.................... $150 \quad 11.01$

Gray drift till plain, chiefly pebbly clay loam................... $430 \quad 38.57$

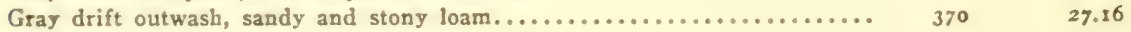

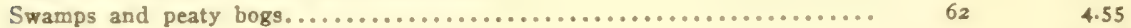

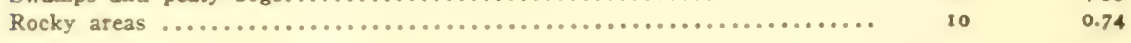

$1,36299.98$

Farm and Crop Data for Stearns County from Census of 1970

Rural population 26,94 I or 20 per square mile

Per cent of land area in farms................................... 87.3

Per cent of farm land improved.................................... 59.4

Average acres per farm....................................... 178.9

Average improved acres per farm................................ 106.3

Value of all farm property....................................... $\$ 34,548,484$

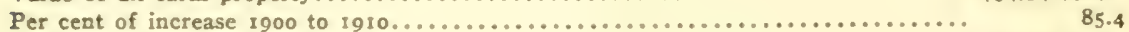

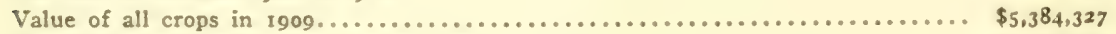

Cereals (wheat, oats, corn, barley, rye)....................... \$4,178,967

Other grains and seeds...................................... \$16r,822

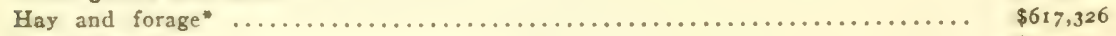

Vegetables ................................................. \$219,733

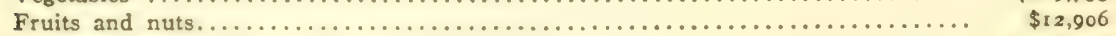

All other crops............................................. \$193,573

- Tame grass, 50,00r tons; wild grass, 106,587 tons.

\section{BENTON COUNTY}

Benton County is situated on the east side of Mississippi River in central Minnesota, with Foley as the county seat. The drainage tends to take courses parallel with the Mississippi rather than toward it. Consequently very little water enters the Mississippi in this county. The western part drains through Elk River southeastward across Sherburne County, while the southeast part drains southeastward into Rum River, which enters the Mississippi at Anoka. 
A large part of the county is occupied by a red drift till plain. The only moraine is a narrow one in the northeast part. There are sandy plains of outwash gravels on the west and south borders, and narrow. belts of dune sand associated with them. The till plain has partially filled interglacial valleys which were eroded in the old gray drift which underlies the red Wisconsin drift at moderate depths and outcrops in some of the bluffs. The red drift of this county though somewhat stony has usually sufficient clay admixture to make a good soil.

An esker, or sharp gravel ridge, several miles in length, runs from Ronnely southwestward, passing just south of Foley. It is of considerable value for railway and road ballast.

Granite outcrops are numerous in the western part of the county, where rock is struck at slight depth in a strip 2 to 3 miles wide and several miles long, extending from Sauk Rapids northward past Watab. There are also small outcrops in the northeast part of the county along West Rum River.

The wet lands of Benton County are estimated by Ralph to occupy I0,000 acres or I 5.6 square miles. A considerable part of the wet land is in the sandy plain along the Mississippi. Some of it is in the line of the partially filled interglacial valleys.

The county was largely covered with hardwood forest, but in the sandy lands along the Mississippi valley and in the southern part of the county there was a light growth of scrub oak.

\section{Percentages of Classes of Land in Benton County}

Square miles Per cent

\begin{tabular}{|c|c|c|}
\hline 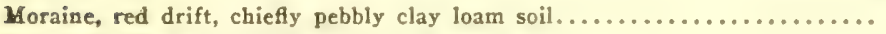 & 10 & 2.47 \\
\hline 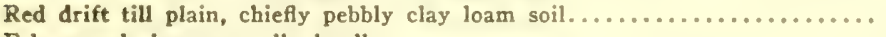 & 288 & 71.11 \\
\hline 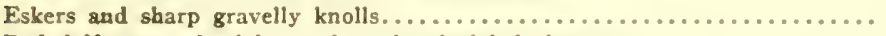 & 2 & 0.50 \\
\hline 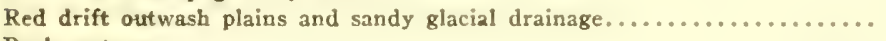 & 70 & 17.28 \\
\hline 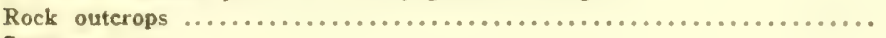 & 20 & 4.94 \\
\hline 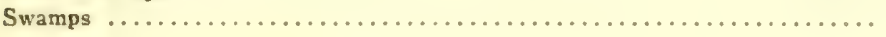 & 15 & 3.70 \\
\hline & 405 & 100.00 \\
\hline
\end{tabular}

Farm and Crop Data for Benton County from Census of sgro

Rural population 7,586 or 38.7 per square mile

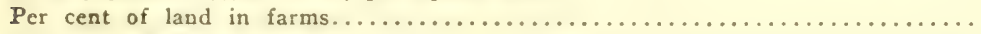

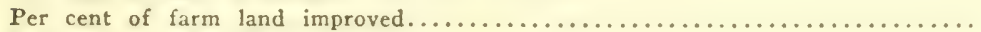

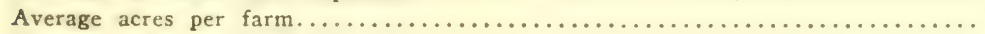

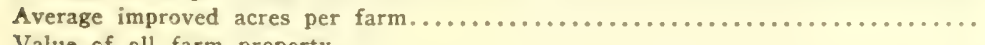

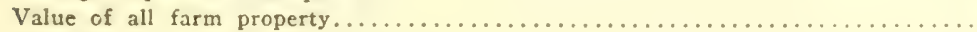

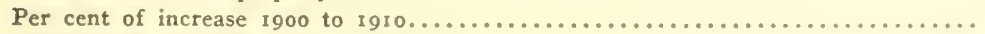

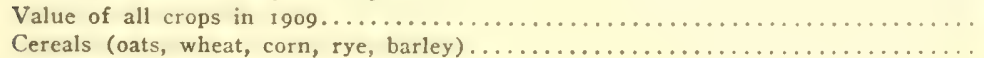

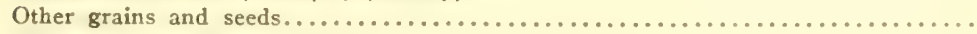

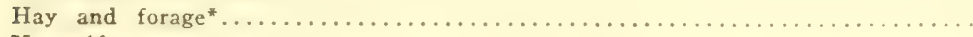

Vegetables

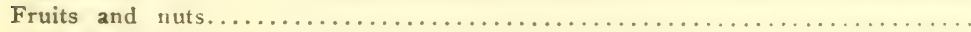

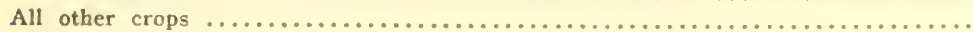

- Tame grass, 14,256 tons; wild grass, 34,22I tons. 


\section{SHERBURNE COUNTY}

Sherburne County is situated east of the Mississippi River, in the south central part of Minnesota, with Elk River as the county seat. It has a land area of 448 square miles, to which should be added I 5 to 20 square miles in lakes.

Elk River gathers nearly all the drainage of Sherburne County and parallels the Mississippi from the northwest to the southeast corner of the county, where it enters the Mississippi. The eastern part of the county drains into Rum River and thence to the Mississippi River at Anoka.

With the exception of the northern edge of the county, where there are a few square miles of clayey ground moraine of red drift, the Grantsburg lobe of the Keewatin ice field covered the entire county. Its morainic ridges and knolls have gray drift material with a large red drift admixture. The movement of the Keewatin ice was northeastward, and the drainage on its north side took a northeastward course along or near the ice border to the end of the lobe and thence down the St. Croix valley. Part of it was ponded, as indicated in the discussion of Mille Lacs and Kanabec counties, but there seems to have been a rather free current across northern Sherburne County which deposited sand and fine gravel rather than mud or silt.

Along the Mississippi and Elk rivers there is a long strip of gravelly ontwash, with light sandy soil. To the east of this strip are large areas covered by fine dune sand, above which there rise a few sharp morainic knolls and ridges. There are gravel plains with light sandy soil also along St. Francis River in the north part of the county. A large area in the southeast part of the county comprises mainly moraines of sandy till with loamy soil.

The amount of wet land in Sherburne County is estimated to be I0,000 acres, and is largely in marshy bogs among sandy areas.

The variable character of the soil is set forth in the table below:

Percentages of Classes of Land in Sherburne County

Square miles Per cent

Sandy gray drift moraine; soil sandy and stony loam.............. $42 \quad 9.38$

Clayey gray drift; soil pebbly clay loam........................ $\quad 15 \quad 3.34$

Sandy gray drift till plain; soil sandy to stony loam................ I4 3.13

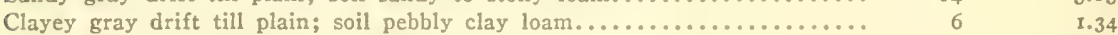

Clayey red drift till plain; soil pebbly clay loam.................. I2 $\quad 2.68$

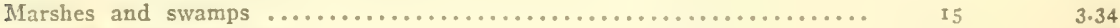

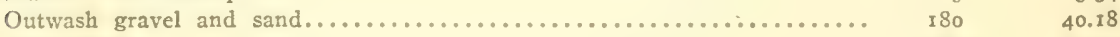

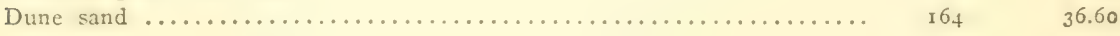

$\quad \overline{448} \quad \overline{99.99}$ 
Farm and Crop Data for Sherburne County from Census of roro

Rural population $5,59 \mathrm{I}$ or 12.5 per square mile.

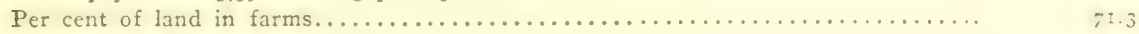

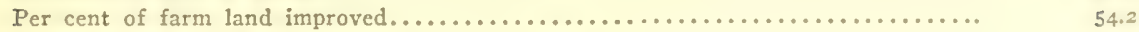

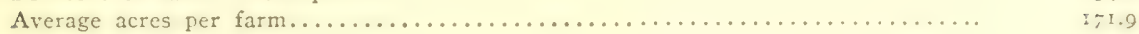

Average improved acres per farm................................ 93.2

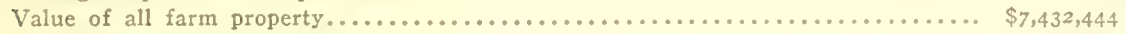

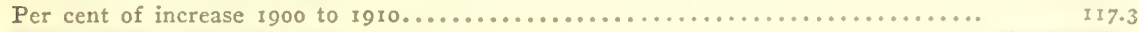

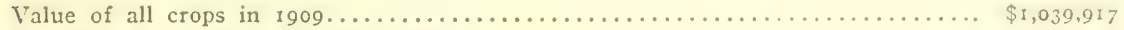

Cereals (corn, oats, rye, wheat, barley)....................... \$558,392

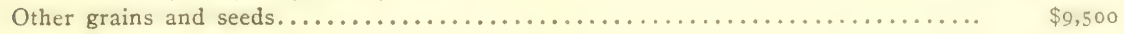

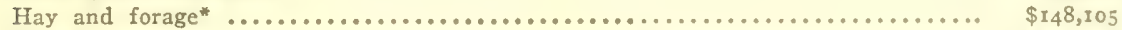

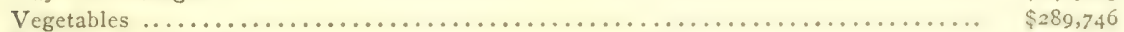

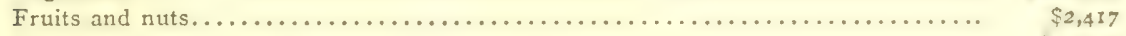

All other crops............................................... $\$ 3 \$, 757$

- Tame grass, 12,28I tons; wild grass, 18,342 tons.

ISANTI COUNTY

Isanti County is located in the eastern part of Minnesota, with Cambridge as the county seat. The greater part of the county is drained southward through Rum River to the Mississippi, but the southeast part drains eastward to the St. Croix River.

This county, like Sherburne, is extensively covered by fine dune sand which has found lodgement on till areas and buried the till to a depth of many feet. Outside the dune sand area there are moraines and till plains and small outwash gravel plains, chiefly in the northern and eastern parts of the county. There is, however, a small morainic area in the southwest part.

The gray till of the Grantsburg lobe extends nearly to the northern limits of the county. Ponded waters outside the ice laid down lake clays in the northwest corner of the county. A few square miles along the north edge of the county have the red till at the surface. The gray drift shows considerable variation in character of soil, both in moraines and till plains, part being clayey and part loose-textured and sandy.

On the dune sand a large amount of truck gardening has been developed, and it has thus become fully as profitable as the till areas. The sand is so fine as to hold considerable capillary water which carries crops through seasons of drouth.

The wet lands of the county are estimated by Ralph to occupy 20,000 acres or 3I square miles. Some of the lakes may have been included in this estimate, as they are very shallow, and in places marshy. Levels of some of the lakes of the western part of the county once stood several feet higher than at present.

Percentages of Classes of Land in Isanti County

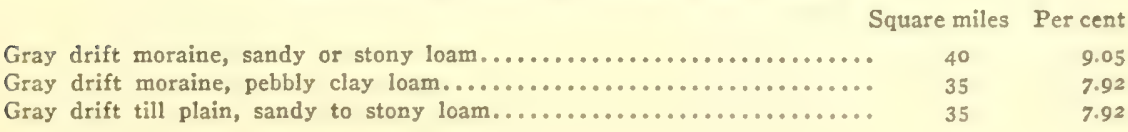




\section{Percentages of Classes of Land in Isanti County (Continued)}

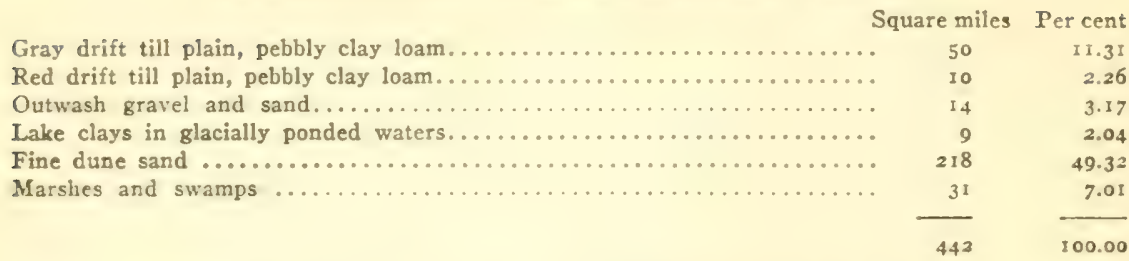

Farm and Crop Data for Isanti County from Census of 1910

Rural poptlation 10,793 or 24.4 per square mile

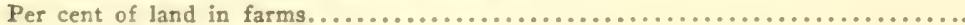

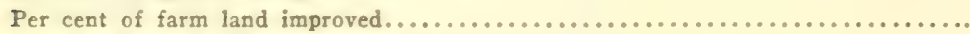

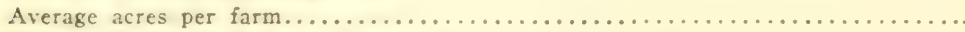

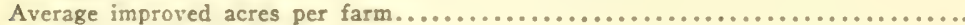

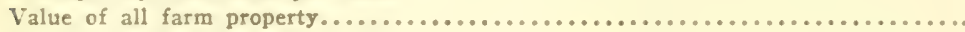

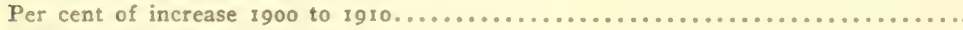

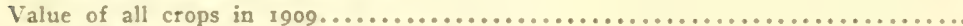

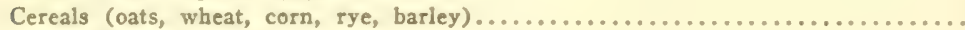

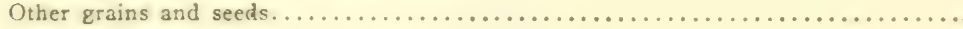

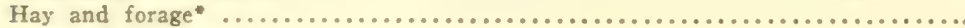

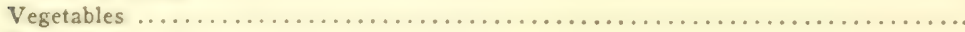

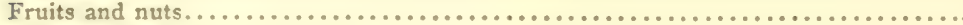

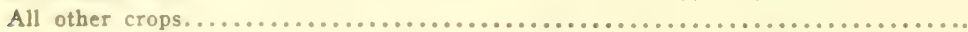

- Tame grass, 18,002 tons; wild grass, 27,695 tons.

84.0
46.1
115.2
53.1
$\$ 9,123,309$
110.6
$\$ 1,366,587$
$\$ 521,758$
$\$ 36,521$
$\$ 207,647$
$\$ 518,608$
$\$ 4,278$
$\$ 77,775$

\section{ANOKA COUNTY}

Anoka County is situated in eastern Minnesota on the east side of the Mississippi River, with Anoka as its county seat. Nearly all the county drains southward or southwestward into the Mississippi, mainly through Rum River. A few square miles in the northeast part drain northeastward to the St. Croix River.

This county is extensively covered by fine dune sand, and the sand areas include large wire grass marshes, the dunes having blocked up the drainage. Most of the dunes were probably formed in the closing part of the glacial enoch, but there are a few places in which they are still active and have blowouts.

The entire county falls within the limits of the Grantsburg lobe of the Keewatin ice field, and carries a sheet of young gray drift. This is exposed at the eastern edge of the dune area in a plain of clayey calcareous till in the southeast part of the county. In the northwest part of the colnty, morainic ridges of the gray drift rise prominently above the surrounding plains. There is a fine gravelly outwash immediately bordering these morainic ridges on the east and south as far out as Rum River. The dune sand sets in east of the outwash plain, and apparently covers the till plain. The fertility of the dune sand is much greater than that of the plains of coarser material, owing probably to its yielding water by capillary action in seasons of drouth. But, in a few places renewed dune action has made very sandy loose soil. 
The wet land of the county is largely embraced in the wire grass marshes which are estimated by Ralph to cover about 17 per cent of the county. Outside the marshes the county is timbered largely with scrub oak.

\section{Percentages of Classes of Land in Aroka County}

Square miles Per cent

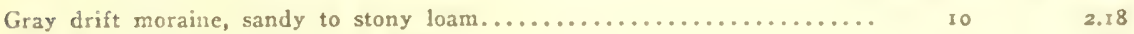

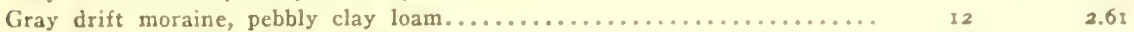

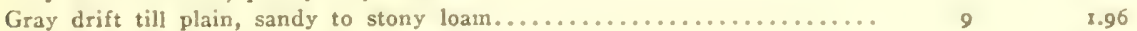

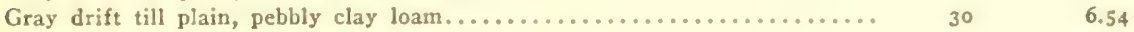

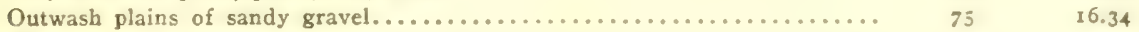

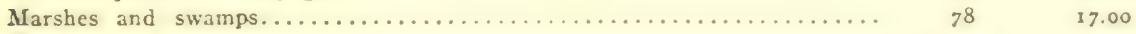

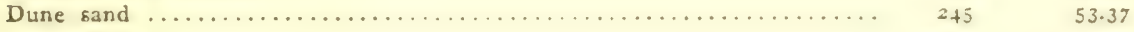

$459 \quad 100.00$

Farm and Crop Data for Anoka County from Census of 1910

Rural population 7,710 or 17 per square mile

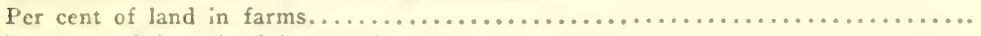

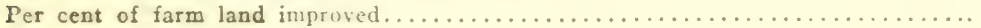

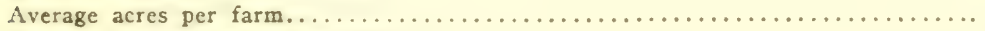

Average improved acres per farm. . . . . . . . . . . . . . . . . . . . . . .

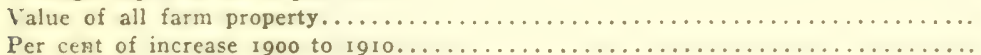

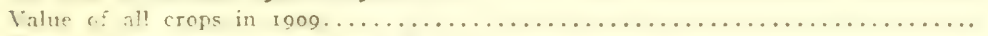

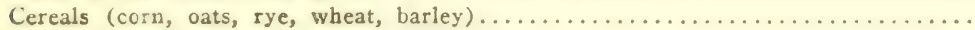

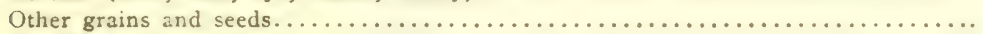

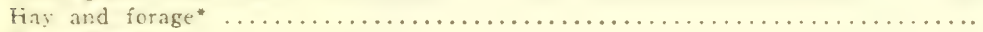

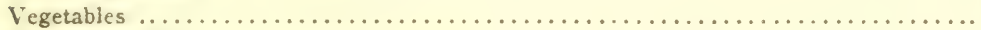

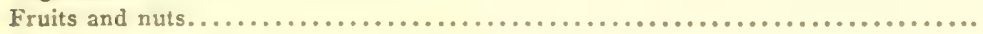

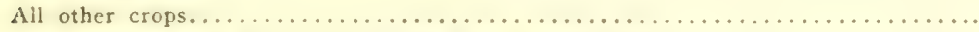

- Tame grass, 56,552 tons; wild grass, 22,814 tons.

\section{CHISAGO COUNTY}

Chisago County is situated on the eastern border of the state with Center City as the county seat. It has a land area of 427 square miles, and lakes occupy an additional 30 square miles. The county all drains to the St. Croix River. The lakes which abound in the southern part of the county seem to be in the line of partly filled valleys.

The entire comty, except a few square miles in the southeast corner, was covered by the Grantsburg lobe of the Keewatin ice field. The most extensive soil class is a pebbly clay loam in a broad plain of young gray till. Near the eastern edge of the county the gray till in places only veneers ridges and knolls of the red drift. There is a broad strip of dune sand in the western part of the county, extending east to Sunrise river and north as far as Harris.

There is a well defined moraine of the gray drift along the east side of Sunrise River, formed on the southeast side of the Grantsburg lobe, and also one in the extreme eastern part of the county. Moraines in 
the northwest part were formed on the northwest edge of the ice lobe. The dune sand covers a low plain along the axis of movement of the ice lobe.

On the dune sand area there were oak openings, but the heavier soil had a more dense forest, largely of oak.

Percentages of Classes of Land in Chisago County

Square miles Per cent

Gray drift moraine, chiefly pebbly clay loam................... $80 \quad$ I8.74

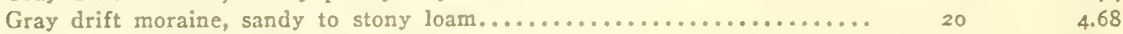

Gray drift till plain, sandy to stony loam...................... I2

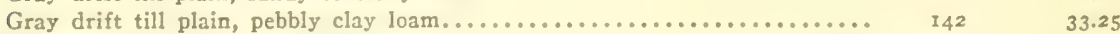

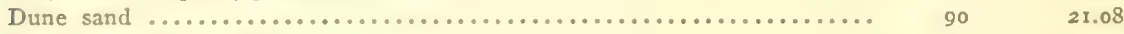

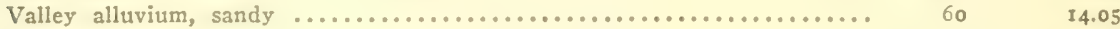

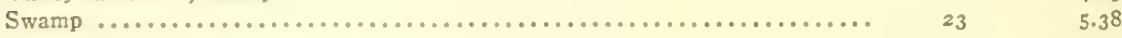

$457 \quad 99.99$

Farm and Crop Data for Chisago County from Census of IgIo

Rural population 9,547 or 22.4 per square mile

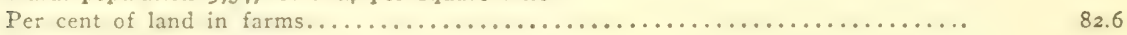

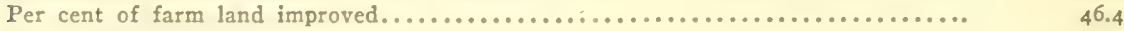

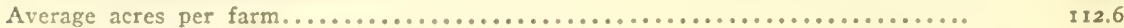

Average improved acres per farm................................. 52.2

Value of all farm property........................................ \$12,289,044

Per cent of increase r 900 to rgro.................................

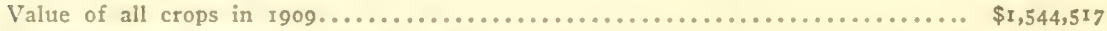

Cereals (oats, wheat, corn, barley, rye) ......................... \$616,999

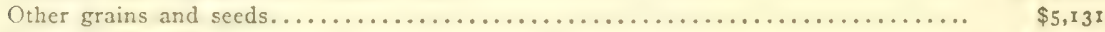

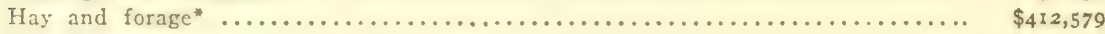

Vegetables ................................................. \$407,986

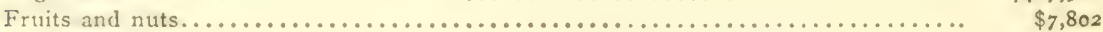

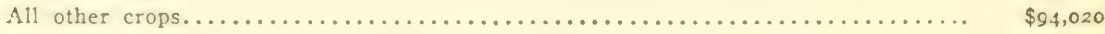

- Tame grass, 41,363 tons; wild grass, 20,020 tons.

\section{WASHINGTON COUNTY}

Washington County is located on the eastern border of the state with Stillwater as the county seat. Its land area is 397 square miles, and there is an additional 2 I square miles in lakes. The greater part of the county drains into the St. Croix River, but a strip along the western edge drains more directly to the Mississippi. The valleys of both these rivers have been deeply channeled and terraced by lines of glacial drainage and larger rivers from the outlets of the glacial lakes Duluth and Agassiz, so that the streams are below the joo-foot contour, while the bordering uplands are 900 to 1,050 feet or more.

The Keewatin young gray drift extends a few miles into the northwest part of the county, northward from White Bear Lake. But in the remainder of the county the red drift is at the surface. The border of the young or Wisconsin red drift lies back a few miles northwest of the junction of the St. Croix and Mississippi rivers, leaving the older red drift exposed in a narrow strip on the west side of the St. Croix below 
the village of Afton. This older red drift has a more mature iramage development than the young red drift, and very few undrained depressions. The later drift is very thickly set with lakes and undrained depressions, and is very largely of morainic topography. The young gray drift forms only a veneer over the red drift, but is sufficiently thick to give it the characteristic pebbly clay loam soil. The red drift is largely a stony loam, though with a considerable admixture of clay.

The county was occupied very largely by oak forest sufficiently open to be classed as oak openings, and farming development started in this county very early.

\section{Percentages of Classes of Land in Washington County}

Square miles Per cent

Old red drift till plain chiefly pebbly clay loam.................. $35 \quad 8.82$

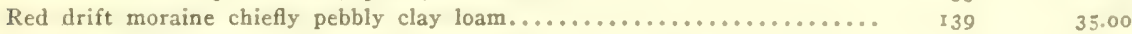

Red drift till plain chiefly pebbly clay loam..................... $25 \quad 6.30$

Red drift outwash and glacial drainage, sandy to stony loam............ $80 \quad 20.16$

Gray drift moraine chiefly pebbly clay loam................... $\quad 28 \quad 7.05$

Gray drift till plain chiefly pebbly clay loam..................... $22 \quad 5.54$

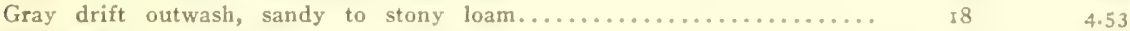

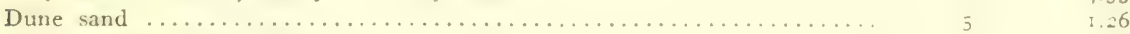

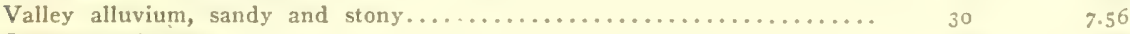

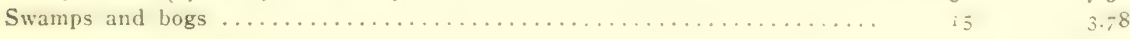

$397 \quad 100.00$

Farm and Crop Data for Washington County from Census of 1910

Rural population II,975 or 30 per square mile

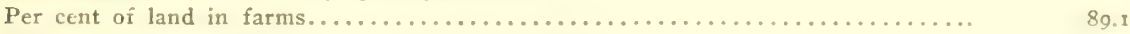

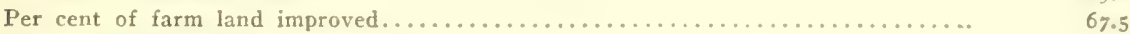

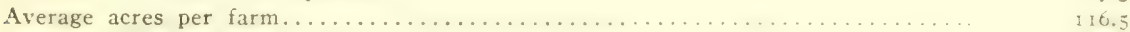

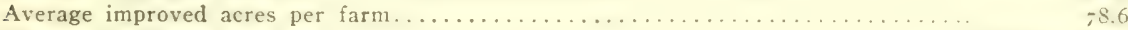

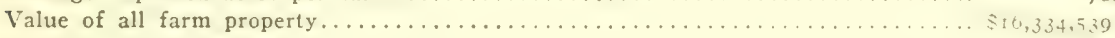

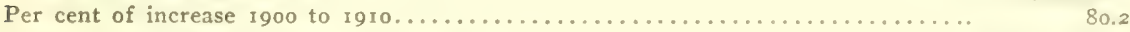

Value of all crops in $1909 . \ldots \ldots \ldots \ldots \ldots \ldots \ldots \ldots \ldots \ldots \ldots \ldots \ldots \ldots \ldots \ldots \ldots \ldots \ldots \ldots \ldots \ldots \ldots \ldots, 129,792$

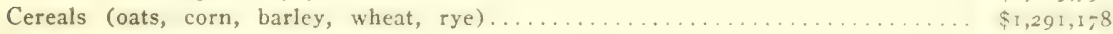

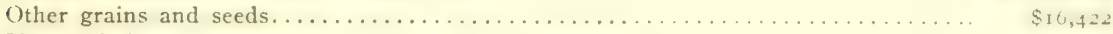

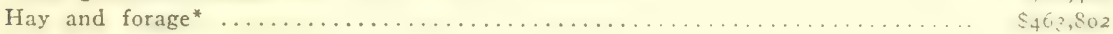

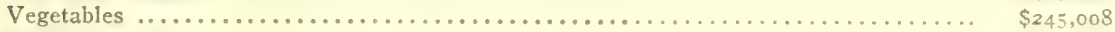

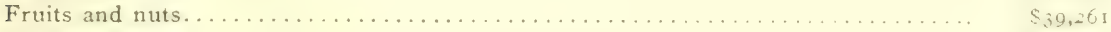

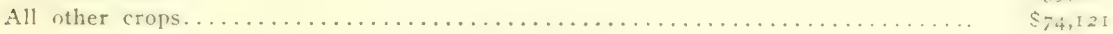

* Tame grass, 47,696 tons; wild grass, 6,294 tons.

Orchard fruits are grown much more than in counties to the north. Vegetables are a less important crop than in the more sandy counties to the north and northwest. Hay is an important crop, and is more largely of cultivated grasses than in the counties remote from the cities of St. Paul and Minneapolis, as only the better classes of hay find good market in the cities.

\section{RAMSEY COUNTY}

Ramsey County, with St. Paul as its seat. is located in the southeastern part of the state, and is the smallest county in the state, its land area 
being only I6I square miles. There is an additional i 3.45 square miles in the lakes and streams within or on the borders of the county.

The Mississippi River is at and near the southern edge of the county in a deep rock-bound valley along part of which broad rock shelves are exposed by erosion and the removal of drift deposits by glacial drainage which made the valley. A small preglacial valley which comes into the present Mississippi near the Union Depot at St. Paul is only partly filled with drift, and furnishes a line of entry for several of the railways coming into the city from the east and north.

There are a few square miles of gray drift in the southwest part of the county, but the remainder of the county is largely red drift moraine with outwash gravel plains among the morainic ridges. The moraines though filled with gravelly pockets usually have at surface a rather clayey till. The morainic ridges in the western part of the county have a thin veneer of gray till, and the drift knolls formed by the Keewatin ice include large masses of red till with the gray till.

The rural population is only 35 persons to the square mile, and the development of intensive farming is less than is usual on the outskirts of a large city. Ordinarily farming is carried on right up to the city limits, and crops of hay are relatively large.

\section{Percentages of Classes of Land in Ramsey County}

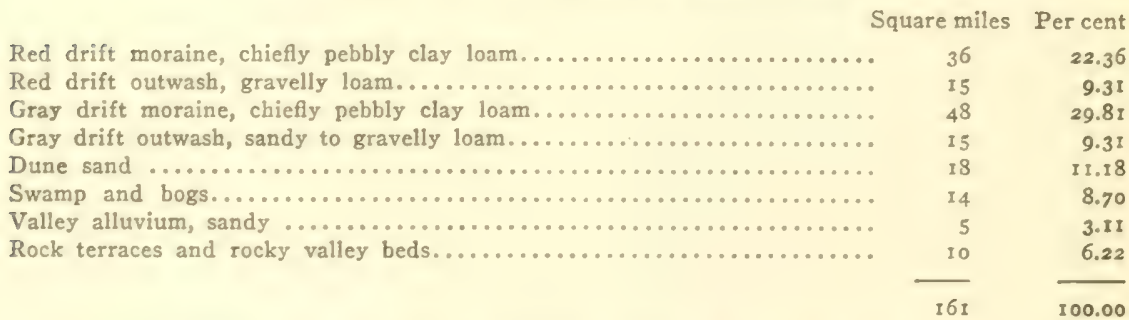

Farm and Crop Data for Ramsey County from Census of 1910

Rural population 5,647 or 35 per square mile

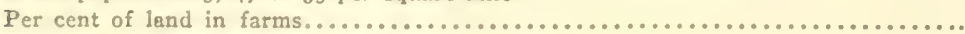

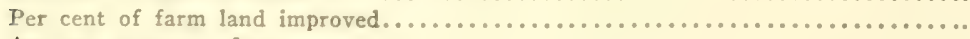

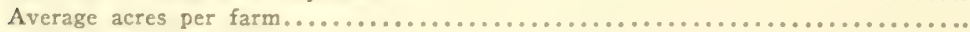

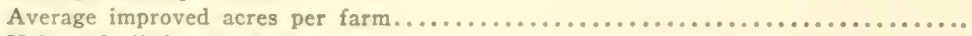

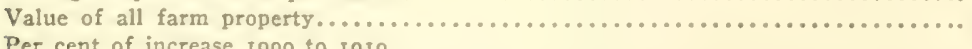

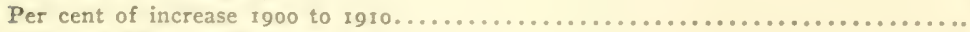

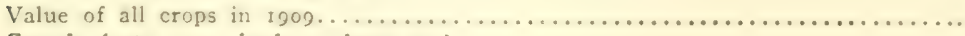

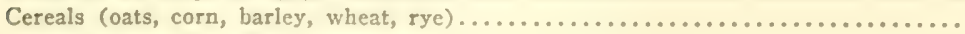

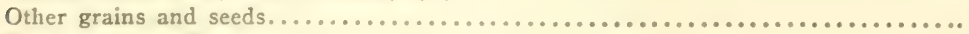

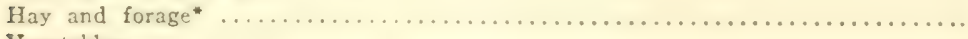

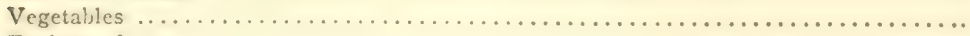

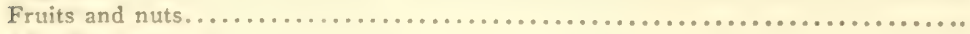

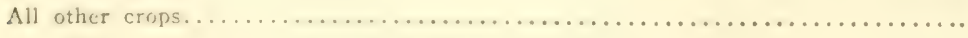

* Tame grass, 16,175 tons; wild grass, 5,552 tons.

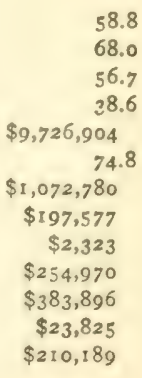




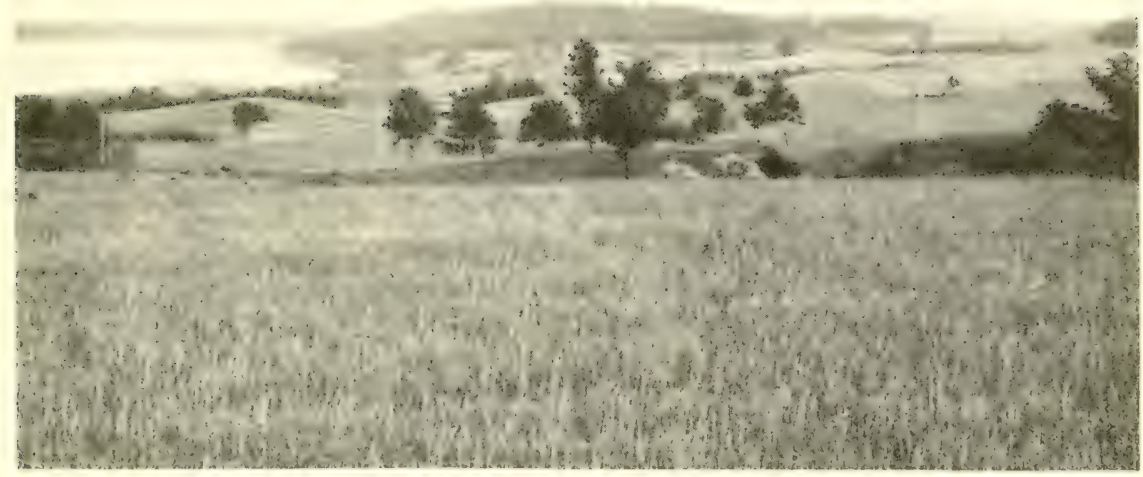

1. GRAY DRIFT MORITNE NORTH OF ST, PATH.

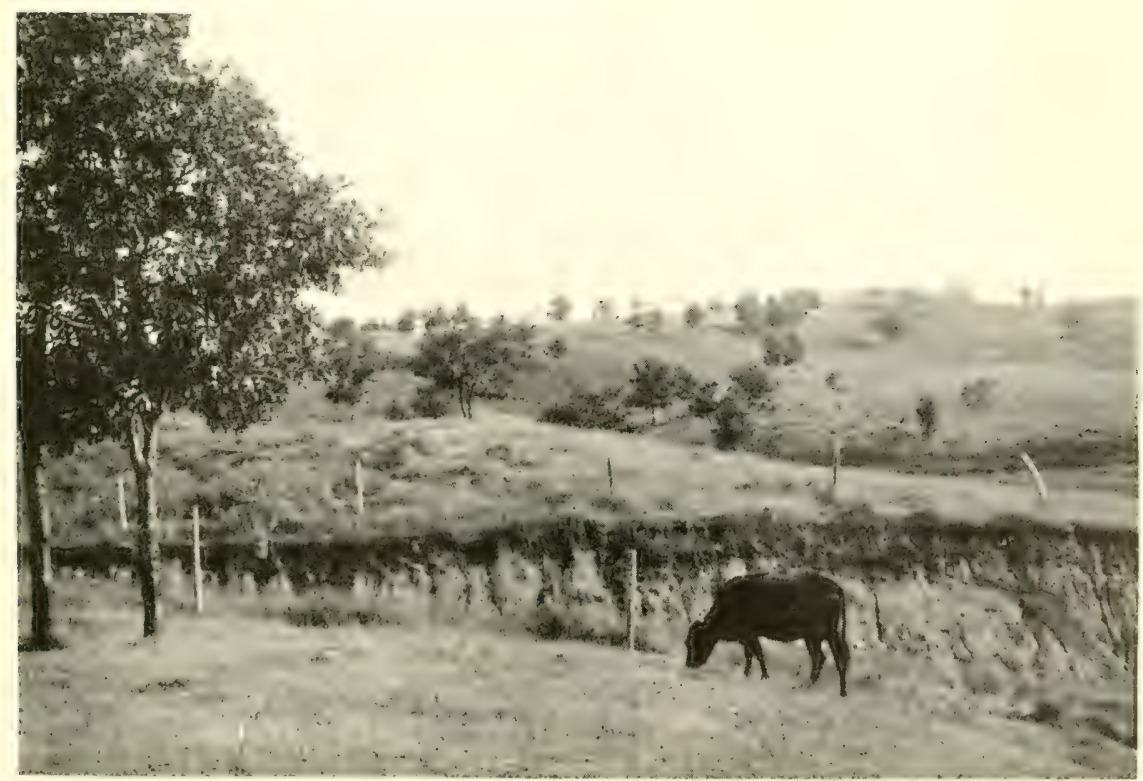

B. RED IRIFT MORAINE WITH COATING OF GRAY DRIFT NOKTII OF ST. P.UL, 

Hennepin County, of which Minneapolis is the county seat, has a land area of 565 square miles, and a water area in lakes and streams of an additional yo square miles. The drainage is largely eastward or northeastward into the Mississippi, there being only a few small creeks flowing to the Minnesota River, which forms part of the southern boundary of the county. Minneapolis has, in the Falls of St. Anthony on the Mississippi, a very valuable water power, which has greatly added to the profits of the farming communities of southern Minnesota by giving milling advantages near home and an excellent market for grain. The Falls of Minnehaha, and much of the picturesque gorge of the Mississippi below the falls of St. Anthony are within the limits of Hennepin County, as is also the beautiful Lake Minnetonka and numerous smaller lakes with attractive scenic features.

With the exception of less than a square mile near Prospect Park, in the east part of Minneapolis, the entire county was covered by the Keewatin ice sheet. In the east part of the county, however, a prominent red drift moraine was overridden by the Keewatin ice and nearly all veneered with the young gray drift. Many of the red gravel plains and ridges were greatly disturbed by the encroachment of the Keewatin ice, and the red drift was thus gathered up and locally incorporated with the gray. From Lake Minnetonka to the north, south, and west, the Keewatin drift is so thick that exposures of the red drift are rare. Outwash plains of gray drift gravel and sand are extensive in the district south of Minneapolis between the Mississippi and Minnesota valleys. They are also notable within the city and northward along the Mississippi valley. These level outwash areas are largely devoted to truck gardening. The rich black loam is highly fertilized and is very productive. The moraines, on the border of Lake Minnetonka, are largely in orchards and vineyards, but elsewhere are commonly given over to general farming.

The occurrence of numerous bogs and marshy depressions among the knolls and ridges causes much waste land, while the hills and ridges themselves are too steep for easy cultivation. The percentage of improved land is therefore low, except on the sandy outwash plains, and many hillside slopes are still in forest. The presence of the forests adds greatly to the beauty of suburban homes and this perhaps more than offsets the agricultural disadvantages. Such suburban occupancy will naturally spread widely over the morainic areas west of Minneapolis, and especially around Lake Minnetonka with its numerous bays and arms.

According to the census of I910, the area planted to potatoes in 1909 amounted to 27 square miles, and about 6 square miles to other vegetables. The gross income from vegetable raising averaged $\$ 36,500.00$ per square 
mile, or about \$57.00 per acre. Large areas near Minneapolis are well adapted to truck gardening, and will naturally be utilized thus in the near future.

\section{Percentages of Classes of Land in Hennepin County}

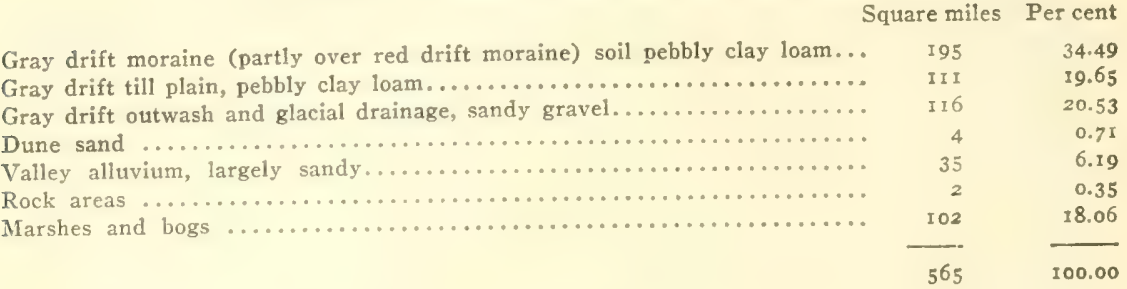

Farm and Crop Data for Hennepin County from Census of Igro

Rural population $₫ 8,806$ or 37.6 per square mile*

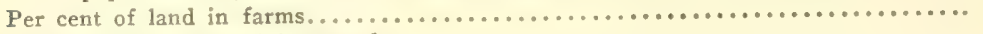

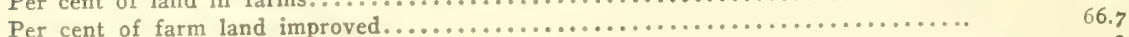

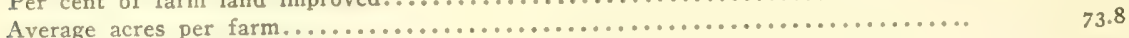

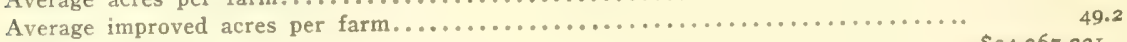

Value of all farm property................................... \$34,967,22I

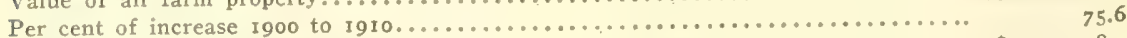

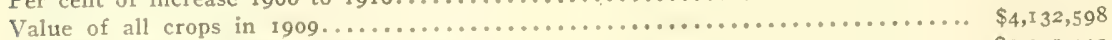

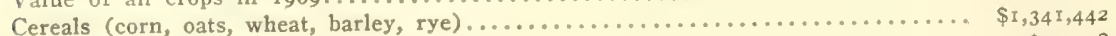

Other grains and seeds........................................ \$10,398

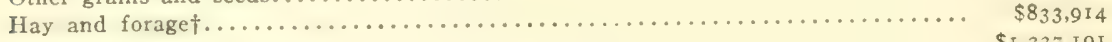

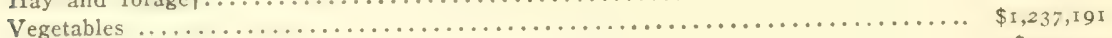

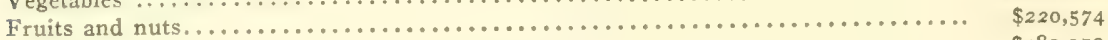

All other crops............................................. $\$ 489,079$

* Deducting city area there remains about 500 square miles in farms.

† Tame grass, 6r, I86 tons; wild grass, 45,52I tons.

\section{WRIGHT COUNTY}

Wright County is situated in the south central part of Minnesota with Buffalo as the county seat. Most of the county is drained to the Mississippi by Crow River, which enters it and also forms part of its eastern boundary. Small lakes are scattered all over the county, and occupy about 23 square miles of its area of 7I4 square miles.

Wright County is crossed by several moraines formed by the Grantsburg lobe of the Keewatin ice field. The ice stood on the Crow valley, while the glacial drainage discharged from the moraines on the northeast side of the lobe to the Mississippi. Outwash aprons, or plains of sandy gravel are thus extensive in the northern part of the county. Smaller ones lie along Crow River valley, which subsequently carried an important line of glacial drainage into the Mississippi. The outwash plains are covered to some extent with a loam which increases their fertility.

Although this county was covered with heavy hardwood forest, it has nearly all been converted into farm land, there being 90.3 per cent of the county in farms. Of this, however, only about 60 per cent is im- 


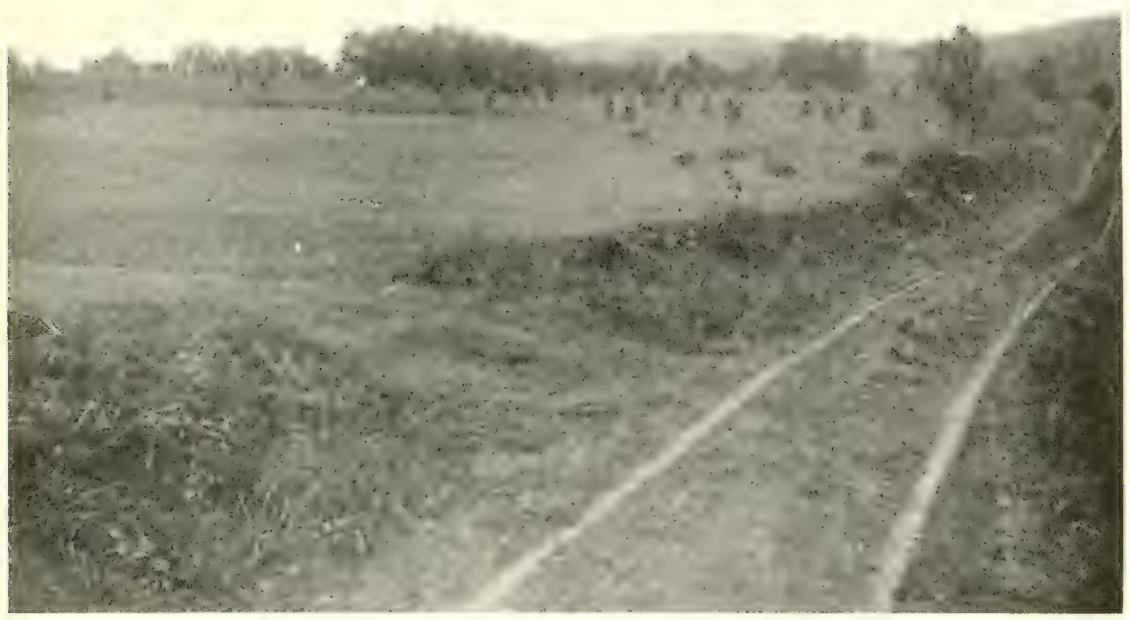

1. WISCONSIN, OR YOUNG RED DRIFT, MORAINE NEAR STILLWATER

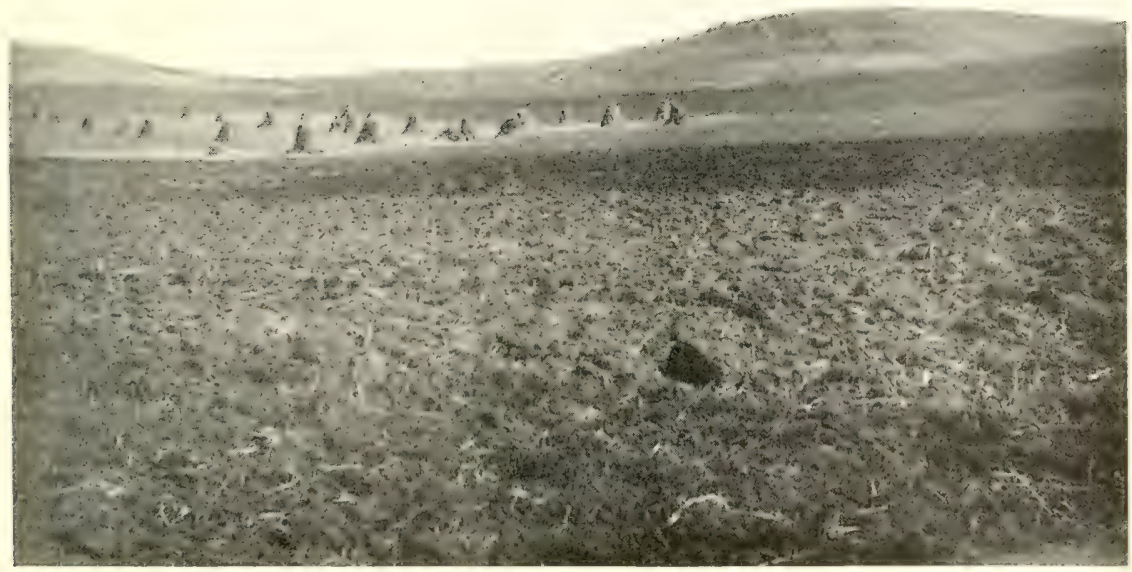

B. OLD RED DRIFT MORAINE NEAR HAMPTON 

proved. Part of the unimproved land is in swamps, but nearly every farm has a few acres of wood-lot. The moraines, though having many small knolls, and a somewhat varied soil, ranging from clayey to gravelly, are developed agriculturally nearly as much as the relatively smooth till plains with prevailing clay loam soil.

\section{Percentages of Classes of Land in Wright County}

Square miles Percent

Gray drift moraine with clayey to mixed soil.................. I $86 \quad 26.9$ I

Gray drift till plain, chiefly pebbly clay loam..................... $230 \quad 33.28$

Outwash plains of sandy gravel and sandy loam soil................ $140 \quad 20.26$

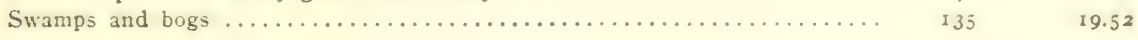

$691 \quad 99.97$

Farm and Crop Data for Wright County from Census of 1910

Rural population 20,064 or 29 per square mile

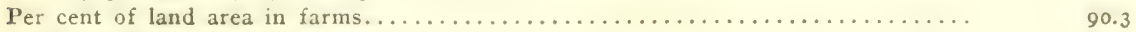

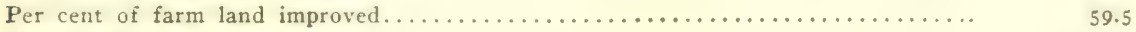

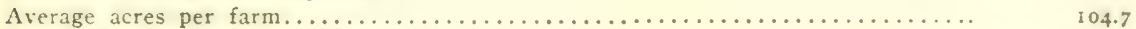

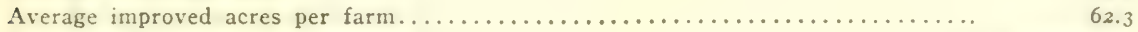

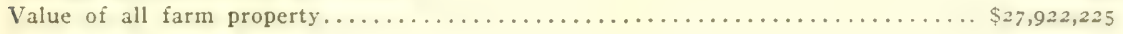

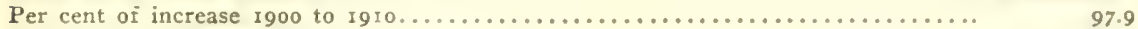

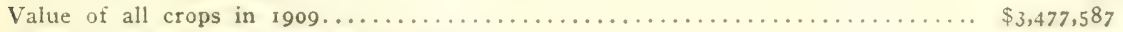

Cereals (wheat, corn, oats, barley, rye) ......................... $\$ 2,586,307$

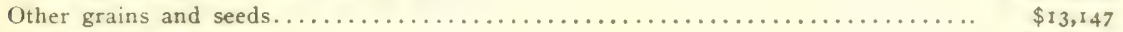

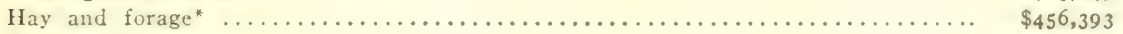

Vegetables ............................................. \$208,349

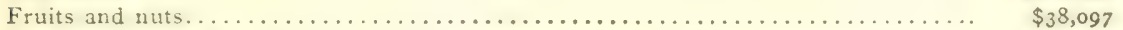

All other crops......................................... \$175,294

* Tame grass, 53,698 tons; wild grass, 52,017 tons.

\section{MEEKER COUNTY}

Meeker County is located in the south central part of Minnesota, with Litchfield as the county seat. The drainage is almost entirely eastward by the two forks of Crow River to the Mississippi. A small area near Eden Valley, however, drains northward to Sauk River, and thence northeast to the Mississippi. At one time in the course of the melting of the Keewatin ice field, this northward line carried the drainage of a large part of the county, for the Crow River valley to the east of Meeker County was still covered by the ice. A lake several miles in width then occupied the low land bordering Crow River valley between Manannah and Kingston, and discharged northward across a broad marshy valley past the site of the village of Eden Valley. This lake deposited a calcareous silt and fine sand brought into it by glacial waters from the east and south. At the south edge of the lake, an extensive outwash gravel plain, on which the villages of Litchfield and Darwin stand, was built by the waters escaping northward from the ice. This lake area and the bordering outwash and till plain lie between two large moraines which 
unite a few miles west in Kandiyohi County to form the great morainic system developed on the east side of the Keewatin ice field.

The northern and earlier of the two moraines just mentioned touches the northwest and also the northeast corner of Meeker County but lies mainly in Stearns County. The southern moraine crosses the southern part of the county, and bears northeastward into Wright County. There is an extensive till plain on the southern or inner border of this moraine, extending from southwestern Meeker County into neighboring counties on the south and west.

The moraines as well as till plains are very largely of clay loam. There are, however, gravelly knolls and ridges along the outer edge of each moraine next to the outwash plains. The sediments of the glacial lake above noted are of fine sand on the edge, but are a rich silt loam in the deeper part between Forest City and Kingston. The outwash plains, though underlain by gravel, have in places a loamy soil and subsoil 2 to 4 feet deep which render them the more productive. A considerable part, however, has a light sandy soil.

Meeker County stands on the border between prairie and hardwood forest. There were groves on the prairie parts and strips of prairie extended back for some miles into the forest. The forest was of oak openings on the sandy soil, but heavier with mixed hardwood on the clay soils.

\section{Percentages of Classes of Land in Meeker County}

\begin{tabular}{|c|c|c|}
\hline & Square miles & Per cent \\
\hline 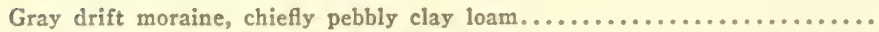 & 190 & 30.59 \\
\hline 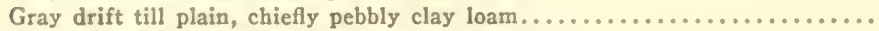 & 260 & 41.87 \\
\hline 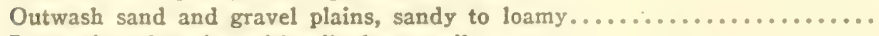 & 70 & 11.27 \\
\hline 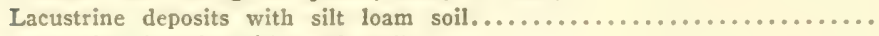 & 30 & 4.83 \\
\hline 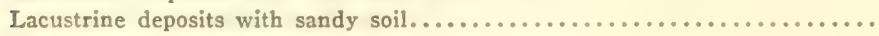 & 40 & 6.44 \\
\hline 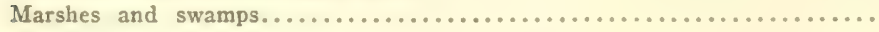 & 31 & 5.00 \\
\hline & 621 & 100.00 \\
\hline
\end{tabular}

Farm and Crop Data for Meeker County from Census of 1910

Rural population 12,826 or 20.6 per square mile

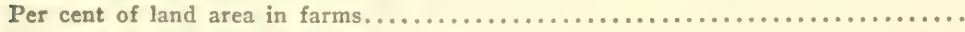

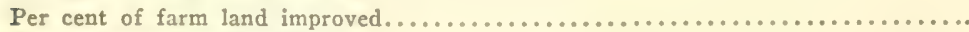

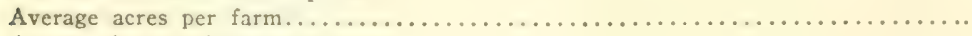

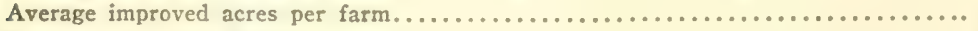

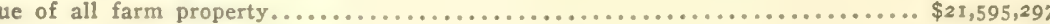

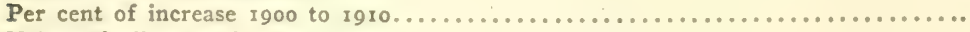

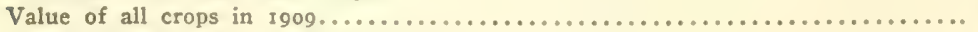

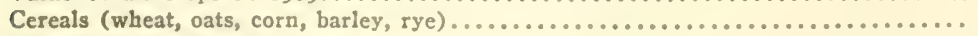

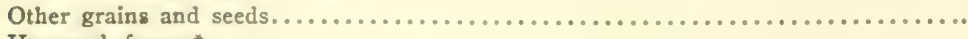

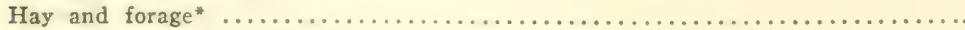

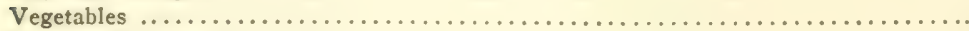

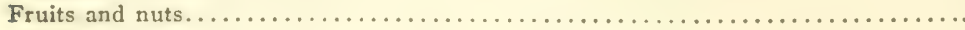

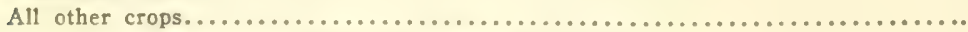

- Tame grass, 34,223 tons; wild grass, 58,252 tons. 


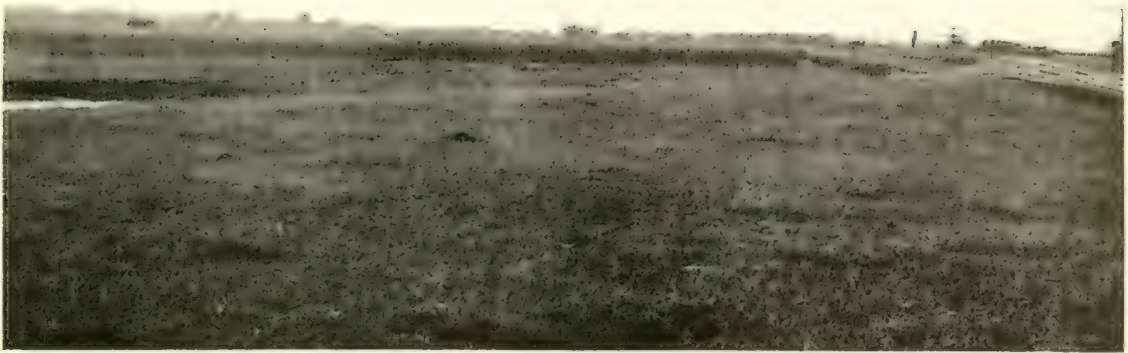

A. OUTWASF PLAIN EAST OF ANOKA. DUNE SAND ON RIGHT CUT BY RAILROAD

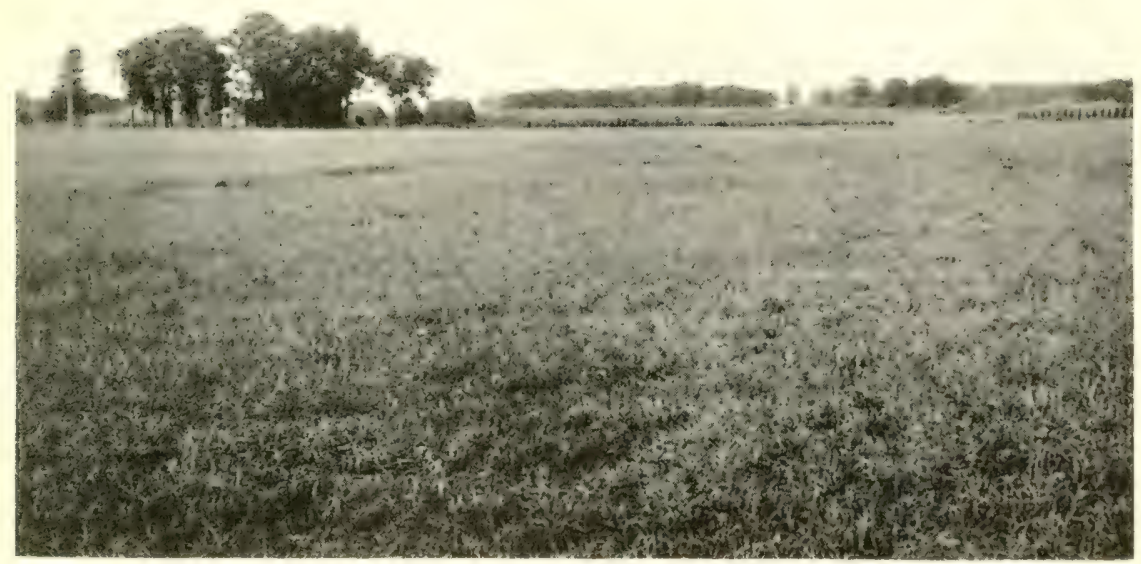

B. OUTWASH PLAIN OF GRAY DRIFT WEST OF WHITE BEAR

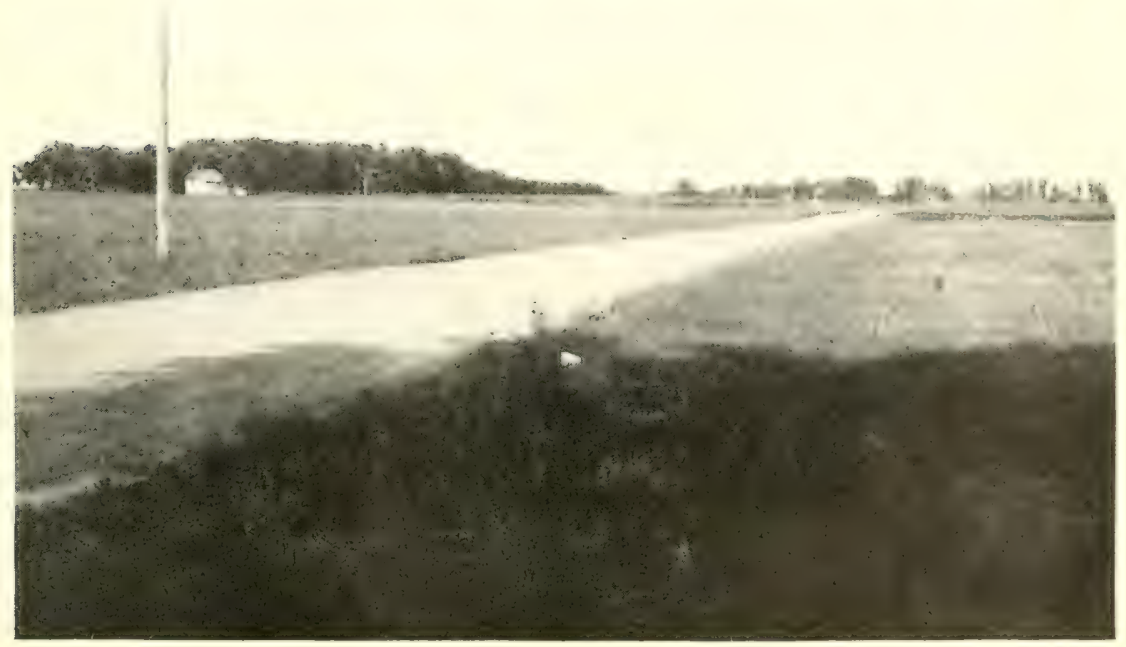

C. OUTWASH PLAIN WITH THICK CLAYEY COVERING NEAR GARTATS AND VADNIS LAKES. NOKTH OF ST, PAUL. 



\section{KANDIYOHI COUNTY}

Kandiyohi County, of which Willmar is the county seat, has a land area of SoI square miles, and an estimated additional lake area of 53 square miles. The lakes are especially numerous in a belt running from northwest to southeast across the county. The drainage of the northeast part is eastward by Crow River to the Mississippi, and of the southwest part is southwestward to the Minnesota River.

The great morainic system formed on the east side of the Keewatin ice sheet comes into the county from the northwest and is combined into a single broad morainic belt as far as Green Lake. It there forks, and the northern or outer member leads northeastward into Stearns County, while the southern member contintes southeastward into Meeker County. There is also a weak moraine leading from Green Lake to Atwater, which is separated from the large moraine south of it by a space of about 2 miles of till plain. South of this great morainic system is a till plain extending into Renville County, the only interruption being a narrow moraine less than a mile wide that runs eastward through the southwest township of the county south of Prinsburg. There are also a few sharp gravelly knolls east of Raymond. Another till plain lies between the two members of the great morainic system east of Green Lake. This is traversed by sandy strips marking lines of glacial drainage to the middle fork of Crow River. The north part of the county is occupied by a great gravel outwash plain that extends into Pope and Stearns counties.

There is gravelly and loose-textured drift along the border of the great morainic system next to the gravel plain, but within 2 or 3 miles back the moraine becomes more clayey, though there are gravelly knolls here and there over it. The till plain has a rich black clay loam soil, such as covers the great plain along the Minnesota valley. Some of the marshes and peaty bogs may be easily drained, but others seem to be down to the level of the underground water table. The marshes and bogs are quite extensive in the gravel plain, and are in some cases 20 to 40 feet below the general level of the plains. The aggregate amount of wet land is probably as great as the area of the lakes, or not less than 6.3 square miles.

Pcrcontages of Classes of Land in Kandigohi Connty.

\begin{tabular}{|c|c|c|}
\hline & Square miles & Per cent \\
\hline Gray drift moraine with gravelly or stony loam.... & 100 & I 2.48 \\
\hline 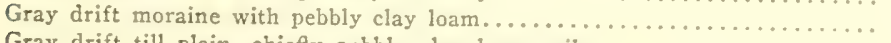 & I 80 & 22.47 \\
\hline 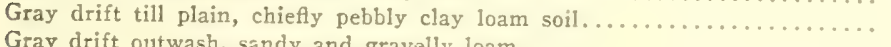 & 378 & 47.19 \\
\hline 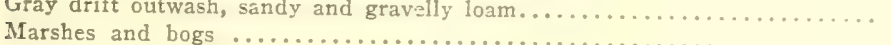 & 80 & 10.00 \\
\hline & 63 & 7.86 \\
\hline & Sor & 100.00 \\
\hline
\end{tabular}


Farm and Crop Data for Kandiyohi County from Census of Igro

Rural population 12,880 or 16 per square mile

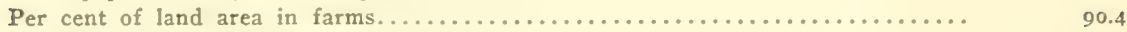

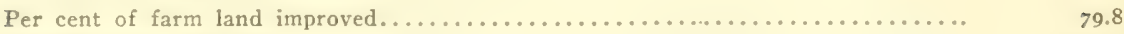

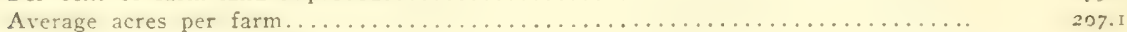

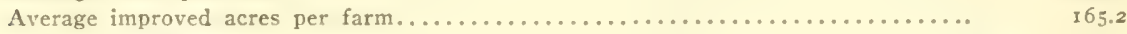

Value of all farm property................................. \$22,711,957

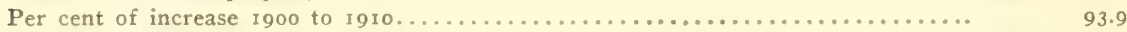

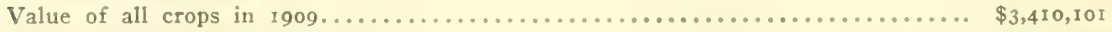

Cereals (wheat, oats, barley, corn, rye)....................... \$2,755,099

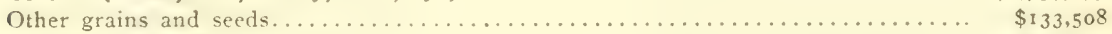

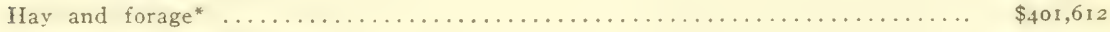

Vegetables, fruits, and nuts.................................... \$62,660

All other crops........................................... $\$ 17,492$

- Tame grass, 29,094 tons; wild grass, 80,684 tons.

\section{SWIFT COUNTY}

Swift County is located in southwestern Minnesota with Benson as the county seat. The drainage is all southward or southwestward through the Pomme de Terre and Chippewa rivers to the Minnesota.

Part of the strong morainic system that was formed along the east side of the Keewatin ice field crosses the northeast corner of the county and occupies about 120 square miles. The remainder of the county is largely till plain, but small till ridges occur here and there in the southern part, and narrow moraines with strips of outwash between them cross the southwest corner of the county. A larger morainic belt traverses the northwest part of the county, and east of this is an extensive sandy outwash plain.

Some marshy land occurs in depressions in the sandy plain northwest of Benson, and there are small areas of wet land on the till plain and a few bogs in the large moraine. But the aggregate area of wet land scarcely reaches 20 square miles. The greater part of the county has a rich black clay loam soil such as characterizes the great till plain along the Minnesota valley.

\section{Pcrcontages of Classes of Land in Swift County}

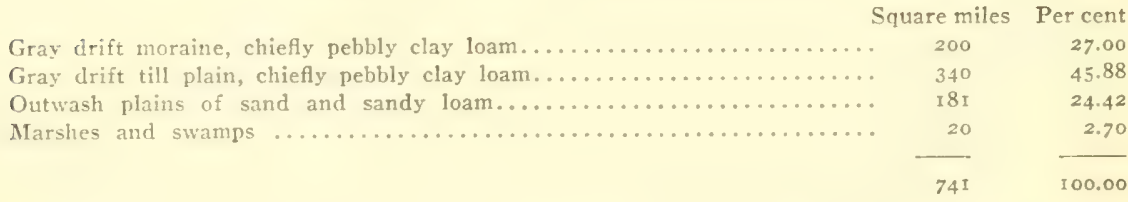

Farm and Crop Data for Swift County from Census of 1910

Rural population 7,533 or 10.2 per square mile

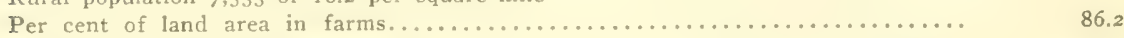

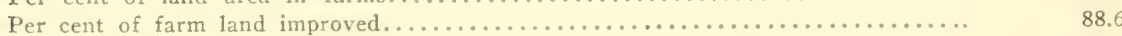

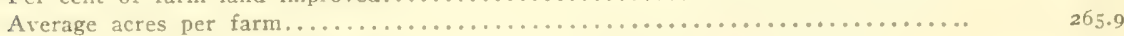

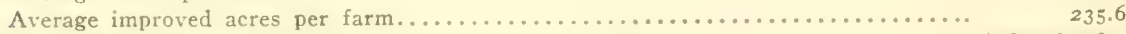

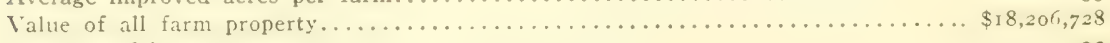

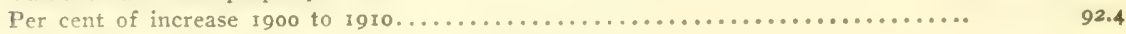


Farm and Crop Data for Swift County (Continued)

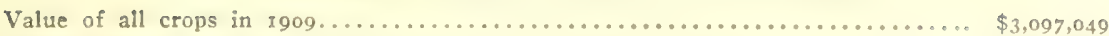

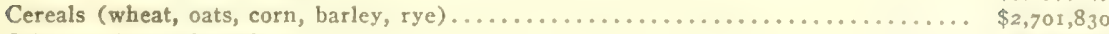

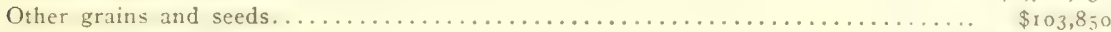

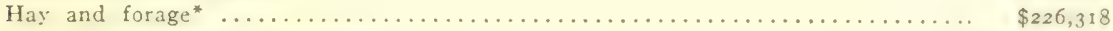

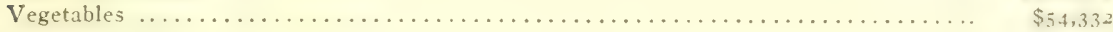

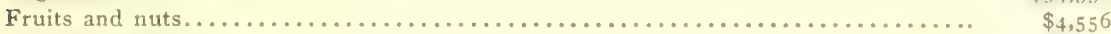

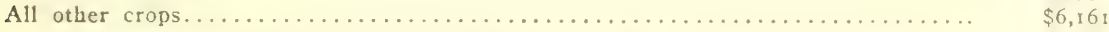

- Tame grass, 19,013 tons; wild grass, 36, I77 tons.

\section{CHIPPEWA COUNTY}

Chippewa County is located on the north side of the Minnesota River in the southwest part of the state, with Montevideo as the county seat. The drainage is all southward or southwestward to the Minnesota River. The Minnesota valley was excavated by the river from the glacial Lake Agassiz to a depth of more than 100 feet, and has several channels in the part above the mouth of the Chippewa River with island-like remnants of the upland between them. The river cut the valley down to the granite in the vicinity of Montevideo and Granite Falls.

The county is nearly all a smooth till plain with black prairie soil and pebbly clay loam subsoil. There are several narrow and interrupted morainic ridges traversing the county in a course parallel with the Minnesota, and these are in some cases bordered on the northeast by narrow strips of sandy outwash. The ridges are usually of clayey till with pebbly clay loam soil. A large part of the Minnesota valley has a stony to sandy loam soil. There is also some wet land in the valley, and perhaps two square miles of bare rock area.

\section{Percentages of Classes of Land in Chippewa County}

Square miles Per cent

Moraines and till ridges, pebbly clay loam..................... $80 \quad 13.52$

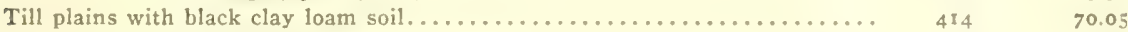

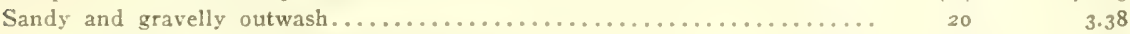

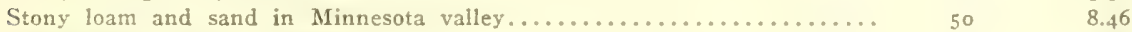

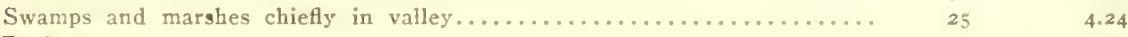

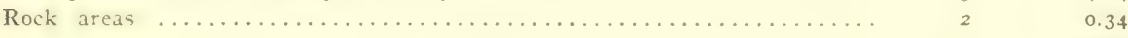

Farm and Crop Data for Chipperva County from $\overline{59 \mathrm{r}}$

Farm and Crop Data for Chippewa County from Census of 1910

Rural population 8,434 or 14 per square mile

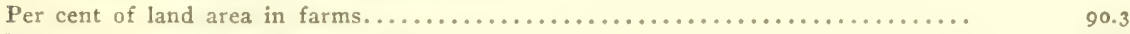

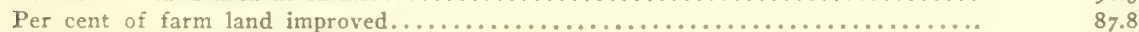

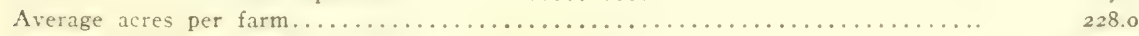

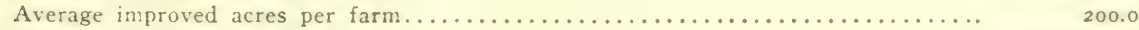

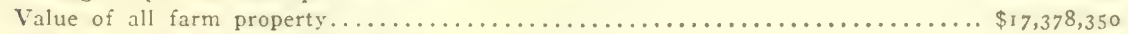

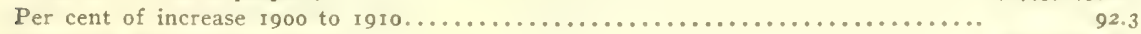

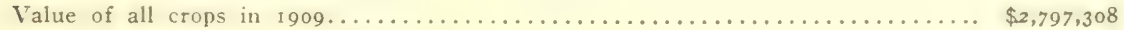

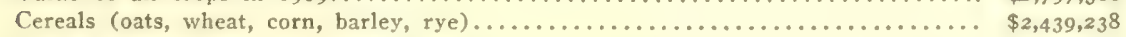

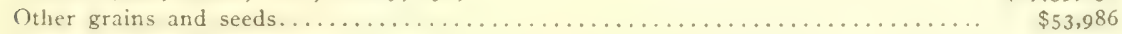

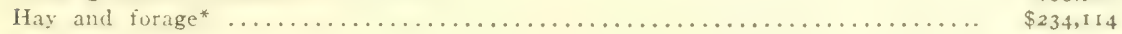

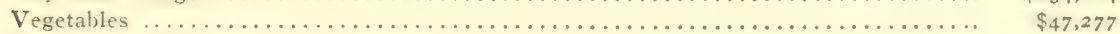

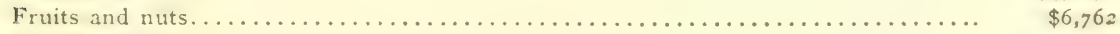

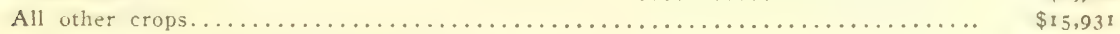

* Tame grass, 20,679 tons; wild grass, 38,909 tons. 


\section{LAC QUI PARLE COUNTY}

Lac qui Parle County is situated south of the Minnesota River on the western border of the state, with Madison as the county seat. The drainage is entirely northeastward into the Minnesota River, mainly through Yellow Bank and Lac qui Parle rivers.

Most of the county is a till plain with an altitude I,O0O to I,200 feet, but the southwest corner is on the slope of the Coteau des Prairies and reaches an altitude of $\mathrm{I}, 400$ feet. The Minnesota valley is cut to a depth of about Ioo feet below the bordering till plain, and as in Chippewa County there are island-like strips of the till plain surrounded by channels cut by the outlet of Lake Agassiz which made the valley of the Minnesota. The village of Louisburg stands on the largest of these island strips. The Minnesota bottoms has exposures of bare granite amounting to perhaps 5 square miles within the county limits. Much of the bottom land is stony and too wet for cultivation.

The till plain has generally a black pebbly clay loam soil. There are several narrow moraines crossing it in the southwest part of the county, and strips of gently undulating land nearer the Minnesota which seem to mark later positions of the ice border. There are chains of gravel knolls in the western part of the county, and scattered gravel knolls in the southeast part. Outwash plains of sand and gravel border some of the weak morainic ridges in the southwest part of the county, but they comprise less than 5 per cent of the area.

\section{Percentages of Classes of Land in Lac qui Parle County}

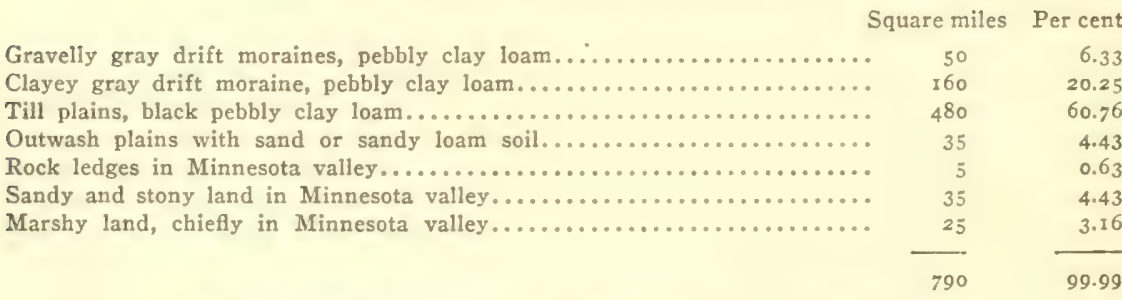

Farm and Crop Data for Lac qui Parle County from Census of IgIo

Rural population 10,819 or 13.7 per square mile

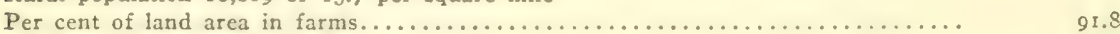

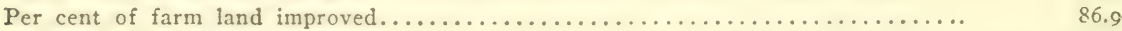

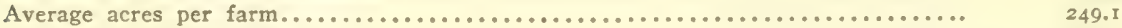

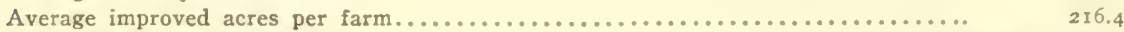

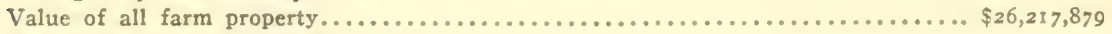

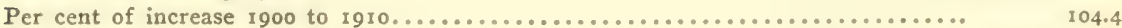

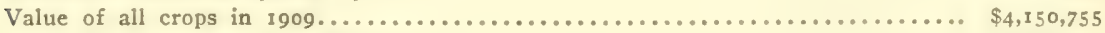

Cereals (wheat, oats, corn, barley, rye)......................... $\$ 3,583,249$

Otker grains and seeds..................................... \$200,372

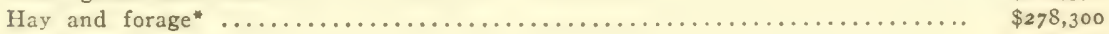

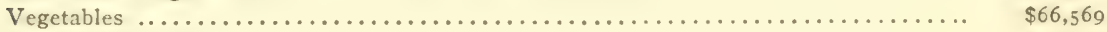

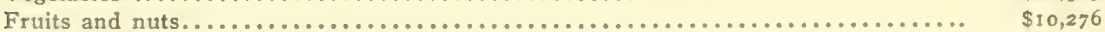

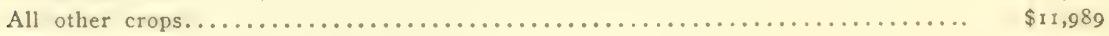

- Tame grass, 32,159 tons; wild grass, 36,957 tons. 


\section{YELLOW MEDICINE COUNTY}

Iellow Medicine County is south of the Minnesota River and extends west to the state line along the south side of Lac qui Parle County. The county seat, Granite Falls, is at the eastern end and takes its name from falls in the Minnesota River at that point. The drainage is all northeastward into the Minnesota chiefly through Lac qui Parle and Yellow Medicine rivers.

The greater part of the county is a till plain standing between $\mathrm{I}, 000$ and 1,200 feet, but the southwest part is on the eastern slope of the Coteau des Prairies and rises near the corner of the county to over 1,700 feet. There are several moraines traversing the county in a northwest to southeast course, but with the exception of a bulky one in the southwest corner they are all slender, with a width of I to 2 miles or even less.

Along the outer or southwest border of the moraines are channels that were formed by the glacial border drainage. These are now in part abandoned and hold marshes and bogs. Some of them, however, are utilized for considerable distances by the present drainage lines. The courses of the streams are subject to great diversion in some cases to find a passage through a morainic ridge.

The moraines contain a few gravel knolls, but are otherwise of a clayey till with pebbly clay loam soil. The lines of border drainage above noted usually have a silty or sandy loam soil. The till plains which occupy a large part of the county have a black prairie soil of slightly pebbly clay loam. The Minnesota valley has in places exposed granite hills, but much of the bottom land is sandy to stony loam with bowldery strips.

\section{Percentages of Classes of Land in Yellow Medicine County}

\begin{tabular}{|c|c|c|}
\hline & quare miles & Per cent \\
\hline 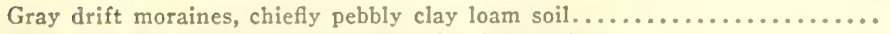 & 235 & 31.38 \\
\hline Gray drift till plains, chiefly pebbly clay loam soil................... & 439 & $58.6 \mathrm{I}$ \\
\hline 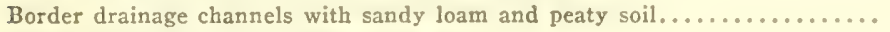 & 50 & 6.67 \\
\hline 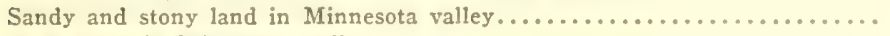 & 20 & 2.67 \\
\hline 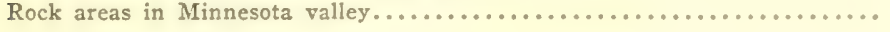 & 5 & 0.67 \\
\hline & 749 & 100.0 \\
\hline
\end{tabular}

Farm and Crop Data for Yellow Medicine County from Census of Igro

Rural population 10,825 or 14.5 per square mile

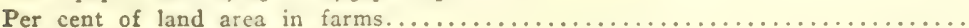

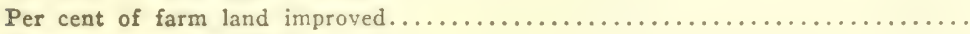

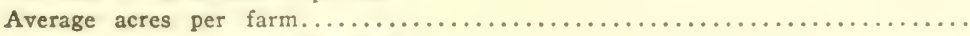

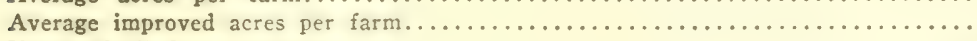

Value of all farm property....................................... $\$ 24,607,037$

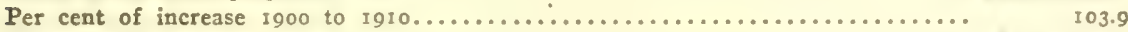

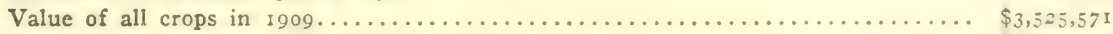

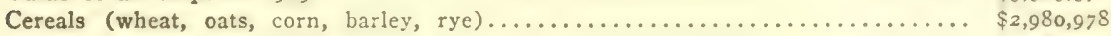

Other grains and seeds.................................... \$185,428

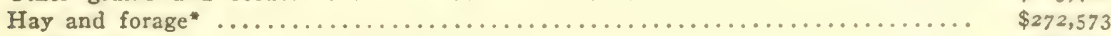

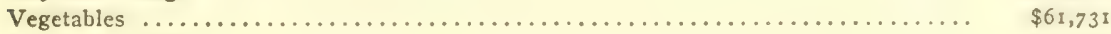

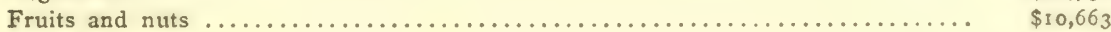

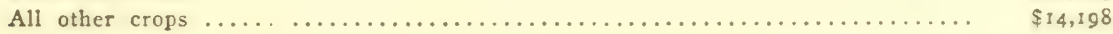

* Tame grass, 28,018 tons; wild grass, $42,3^{14}$ tons. 


\section{RENVILLE COUNTY}

Renville County is situated on the north side of the Minnesota River in the southwest part of the state, with Olivia as the county seat. The greater part of the county is drained southward to the Minnesota River, but the northeastern part is drained northeastward by Crow River to the Mississippi. The county has so few natural drainage lines that extensive ditching has been found necessary to carry off the surplus water.

This county is a great prairie till plain, with only a few narrow drift ridges or weak moraines that are more or less interrupted. The soil is a rich black clay loam. In a few places it is thickly strewn with bowlders. Gravel knolls, which are of high value for road ballast, are scattered widely over the plain and strewn along the lines of the moraines. The plain stands mainly between I,000 and I,I00 feet above sea level, though its highest points are slightly above r, Ioo feet. On this upland plain, wet lands can largely be drained and rendered tillable at moderate expense. The Minnesota River falls 50 feet or from 850 feet above sea level to 800 feet in its course along the border of the county. Its valley has numerous outcrops of granite rock, which in places rise to a height of 100 feet or more above the stream, or to within about 50 feet of the level of the bordering uplands. Parts of the bottom lands are wet and parts are sandy and stony.

\section{Percentages of Classes of Land in Renville Connty}

Square miles Per cent

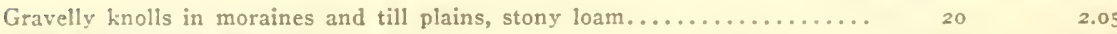

Gray drift ridges, pebbly clay loam........................... II . II.25

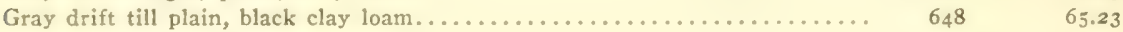

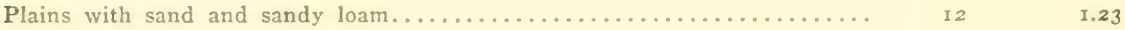

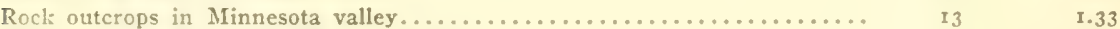

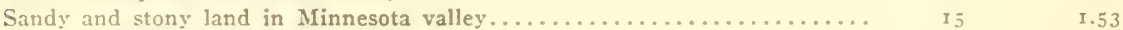

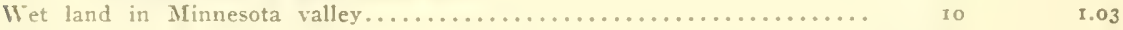

Upland marshes and wet lands............................. $150 \quad 15.33$

$978 \quad 99.98$

Farm and Crop Data for Renville County from Census of 1910

Rural population 15,794 or 16 per square mile

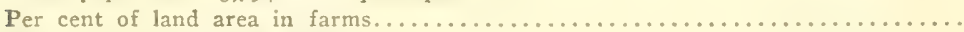

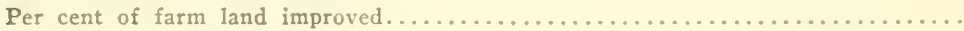

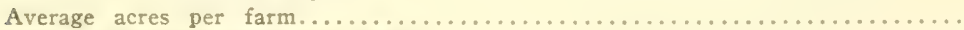

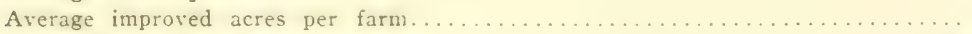

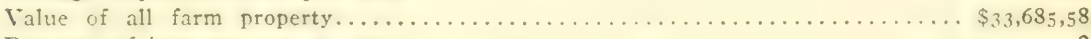

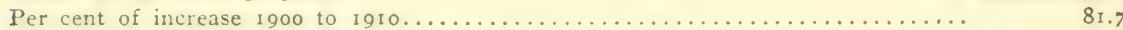

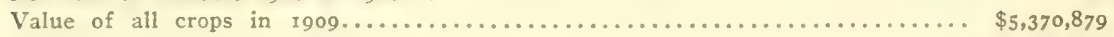

Cereals (wheat, oats, corn, barley, rye)......................... \$4,780,876

Other grains and seeds.................................... $\$$ Ir 8,823

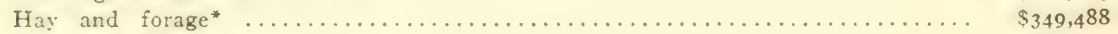

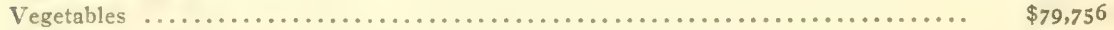

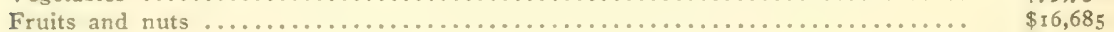

All other crops .......................................... $\$ 251$

* Tame grass, 33,400 tons; wild grass, 87,880 tons. 


\section{MCLEOD COUNTY}

McLeod County is situated about midway of the state in the fourth row of counties from the south, with Glencoe as the county seat. The drainage is nearly all northeastward to the Mississippi through Crow River, but the southern end drains eastward to the Minnesota.

The county is nearly all a very fertile till plain, and most of it stands between I,O0O and I,IOO feet above the sea, there being remarkably little range in altitude. The northwest corner is strongly morainic as it embraces the southern end of a spur from the great morainic system formed on the east side of the Keewatin ice field. This spur is at the place where the Grantsburg lobe branches off from the main or Des Moines lobe. Gravel knolls are scattered over the county in such a manner as to be accessible for road ballast in nearly every township, but the plains have black clayey loam with but few pebbles or bowlders.

Marshes and peat bogs are inclosed among the morainic knolls of the northwest part of the county and also fringe some of the lakes. A narrow strip of sandy gravel follows down the south fork of Crow River, which may have been a line of glacial drainage; but aside from this no outwash plains or sandy glacial drainage lines were noted.

Percentages of Classes of Land in McLeod County

\begin{tabular}{|c|c|c|}
\hline & Square miles & Per cent \\
\hline 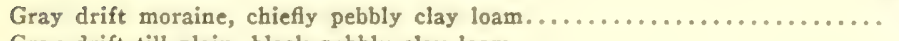 & 60 & 12.09 \\
\hline 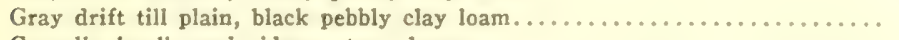 & 370 & 74.60 \\
\hline 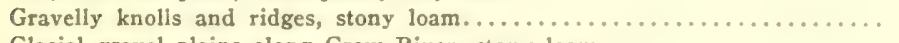 & 25 & 5.04 \\
\hline 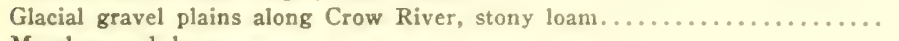 & 15 & 3.02 \\
\hline 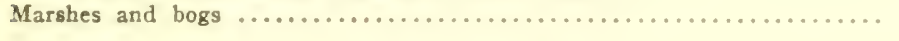 & 26 & 5.24 \\
\hline
\end{tabular}

Farm and Crop Data for McLeod County from Census of Igro

Rural population 12,278 or 25 per square mile

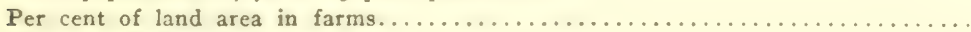

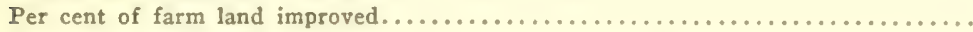

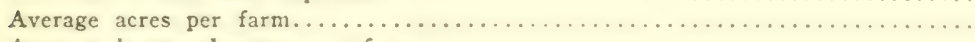

Average improved acres per farm .

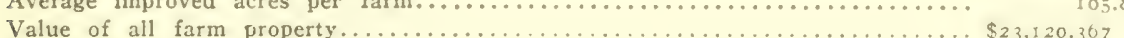

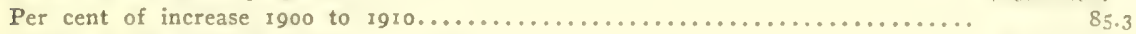

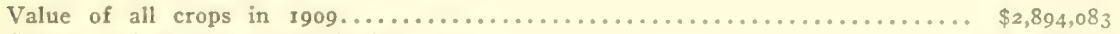

Cereals (wheat, corn, oats, barley, rye)....................... \$2,382,431

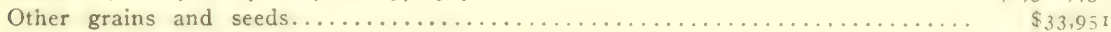

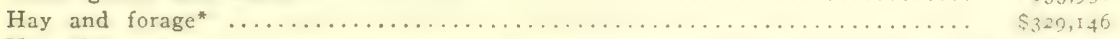

Vegetables .................................... $\$ 10,702$

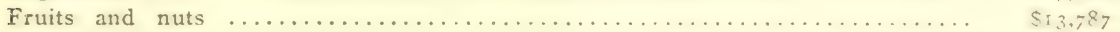

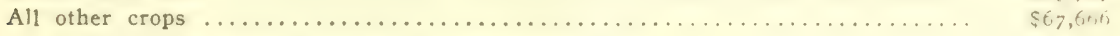

- Tame grass, 33,458 tons; wild grass, 5 I,192 tons.

\section{SIBLEY COUNTY}

Sibley County lies west of the north flowing portion of Minnesota River, with Gaylord as its county seat. The drainage is nearly all eastward to the Minnesota. A narrow strip on part of the north border is 
drained northeastward by Crow River to the Mississippi. The altitude of the county, outside the Minnesota valley, is remarkably uniform, there being scarcely 100 feet variation. The northwest part stands about 1,050 to 1,075 feet, and there is a gradual descent to the southeast part, which is about 975 feet. The Minnesota valley is nearly 250 feet deep, the river being 717 feet at the south line of the county and just below 700 feet where it leaves the county. There are, however, terraces of glacial gravel along it 100 to 125 feet above the stream.

More than 90 per cent of the county, outside the river valley, is a smooth till plain, which was largely prairie, and has a rich black clay loam soil. There are weak morainic ridges in the southwest corner of the county, and occasional low knolls scattered widely over the county. The knolls and the morainic ridges contain a small amount of gravel, of great value for road ballast. The bottom lands and terraces of the Minnesota valley are generally sandy. There is a small amount of wet land lying below the level of the highest flood stages of the river. This land is rich and can be farmed except in years of exceptional floods.

\section{Pcrcentages of Classes of Land in Sibley County}

Square miles Per cent

Moraines and scattered drift knolls, chiefly pebbly clay loam........... $30 \quad 5.1 \mathrm{I}$

Till plain, black pebbly clay loam............................. $470 \quad 80.40$

$\begin{array}{llll}\text { Upland swamps and wet land, largely capable of drainage, black clay loam. } & 60 & 10.22\end{array}$

Sandy bottoms and terraces of Minnesota valley.................... 10 10

Wet bottoms of Minnesota valley............................. I5

$585 \quad 100.00$

Farm and Crop Data for Sibley County. from Census of Ioro

Rural population $1 \mathrm{I}, 35 \mathrm{I}$ or 19.4 per square mile

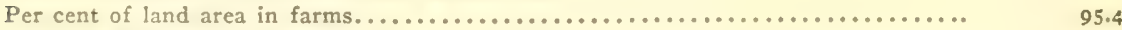

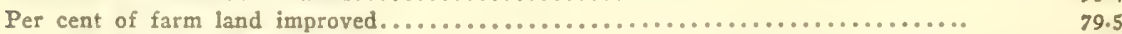

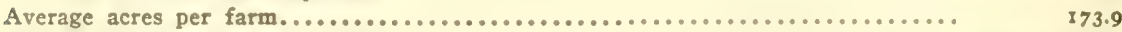

Average improved acres per farm..................................

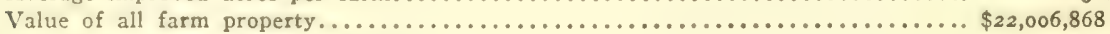

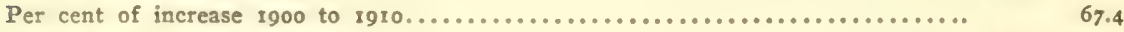

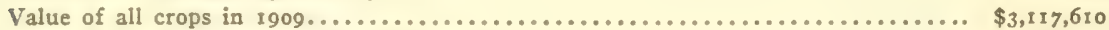

Cereals (wheat, corn, oats, barley, rye).......................... \$2,678,817

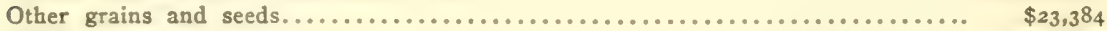

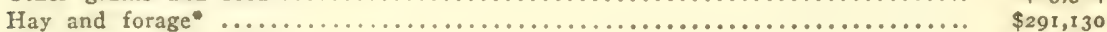

Vegetables .................................................. \$60,302

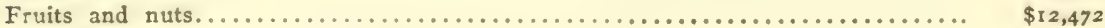

All other crops............................................ \$51,505

- Tame grass, 22,525 tons; wild grass, 67,183 tons.

\section{CARVER COUNTY}

Carver County is situated on the west side of the north flowing part of Minnesota River immediately southwest of Hennepin County, and Chaska is the county seat. The southeastern part of the county drains into the Minnesota River, but the northwest part is drained to the Mississippi River, chiefly by Crow River. 
This county is largely occupied by the great morainic system formed on the east side of the Keewatin ice field, and has a knolly surface inclosing numerous small lakes and peat bogs. The western end of the county is a till plain, a continuation of the great plain bordering the Minnesota valley. There are also small till plains inclosed among the morainic ridges. Outwash plains open into the Minnesota valley, and the discharge of glacial waters was thence northeastward to the Mississippi.

The forests and lakes give a pleasing scenic effect and attractive setting for suburban residences. The county is traversed by several railroad lines leading direct to Minneapolis, and thus is likely to have in the near future a considerable suburban population. It is also favorably situated for quick marketing of produce, and much loose textured soil suitable for gardening. Thus far, however, it has been chiefly a grain and hay producing county. The till plain in the southwest part of the county has a rich black clay loam soil with pebbly clay loam subsoil.

Percentages of Classes of Land in Carver County

Square miles Per cent

Gray drift moraines, pebbly clay loam to gravelly loam soil........... $140 \quad 37.23$

Outwash plains of sandy and gravelly loam.................... II $\quad 2.93$

Till plains, chiefly of pebbly clay loam........................ $180 \quad 47.87$

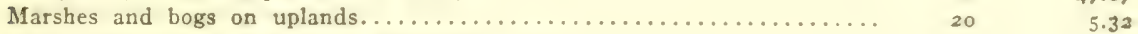

Sandy bottoms and terraces of Minnesota valley................. $15 \quad 3.99$

Wet bottoms of Minnesota valley............................ 10 10 2.66

$376 \quad 100.00$

Farm and Crop Data for Carver County from Census of roro

Rural population 11,247 or 30 per square mile

Per cent of land area in farms.................................. 89.9

Per cent of farm land improved..................................

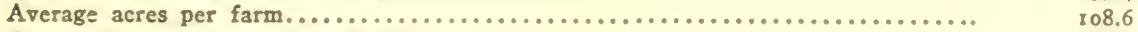

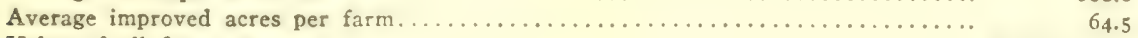

Value of all farm property.................................. \$20,370,744

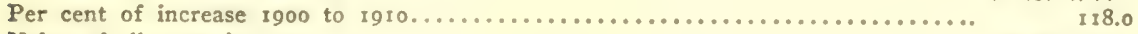

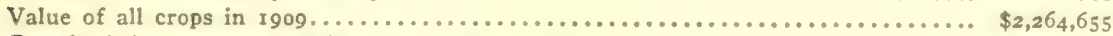

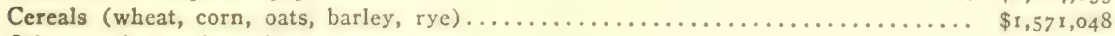

Other grains and seeds...................................... $\$ 1,7 r y$

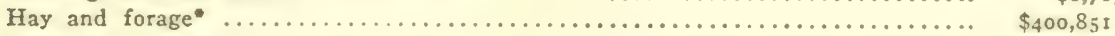

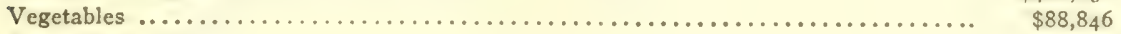

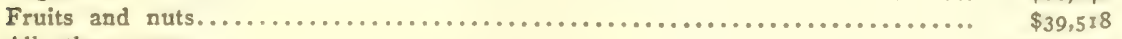

All other crops......................................... \$162,675

- Tame grass, 46,934 tons; wild grass, 29,890 tons.

\section{SCOTT COUNTY}

Scott County is situated on the east side of Minnesota River with Shakopee as the county seat. The drainage is northwestward to the Minnesota River, except a few square miles in the southeast part which drain eastward through Vermilion River to the Mississippi. The Minnesota valley is over 200 feet in depth, the river being below 700 and the 
bluffs over 900 feet. There are only a few square miles of the county standing above I, IOO feet.

The greater part of the county is strongly morainic, and is in the great morainic system formed on the east side of the Keewatin ice field. A till plain on the inner border of this morainic system occupies the southwest part of the county. Red drift is intermixed with the gray drift in notable amount in the east part of the county, and is found in outcrops and valley slopes beneath the gray drift clear to the western end of the county. The greater part of the drift, both in the moraines and till plains, is a clayey calcareous till with pebbly clay loam soil. There are, however, occasional knolls of gravel, and inclusions of gravel in the till which furnish suitable material for road ballast.

The Minnesota valley has broad terraces of sandy gravel at various heights up to more than Ioo feet above the stream. On a low terrace west of Savage, the soil is in places light dune or sand but from Shakopee prairie up to Belle Plaine prairie there is usually a loany rich soil. Rock ledges are exposed, or covered very thinly with loam and gravel, over an area of several square miles in the vicinity of Shakopee and Merriam. Low bottoms, subject in part to overflow, occupy about one fourth of the area of the valley in this county.

Percentages of Classes of Land in Scott County

Square miles Per cent

Gray drift moraine, chiefly pebbly clay loam................... 180

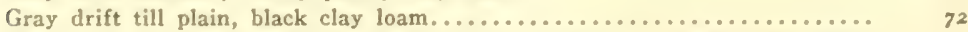

Glacial drainage deposits of gravel and sand, terraces on Minnesota River

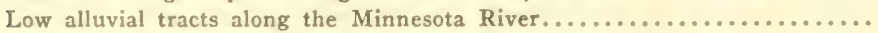

Marshes and bogs on uplands.

Farm and Crop Data for Scott County from Census of 1910

Rural population 9,885 or 27 per square mile

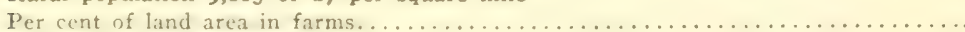

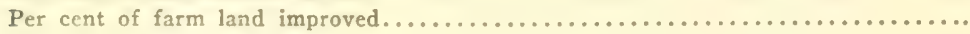

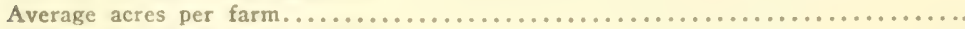

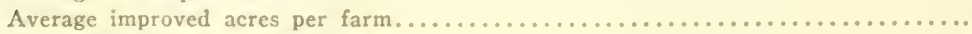

Value of all farm property................................. \$14,610,955

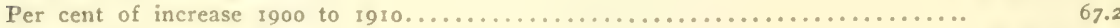

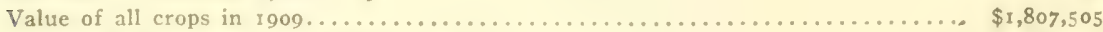

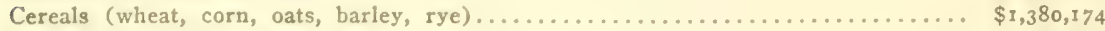

Other grains and seeds...................................... $\$ 4,808$

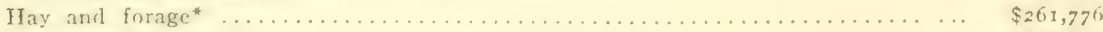

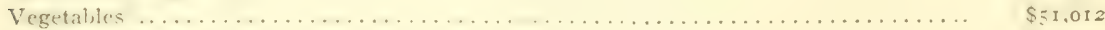

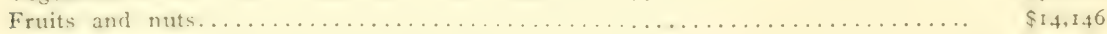

All other crops..................................... $\$ 95,589$

* Tame grass, 17,148 tons; wild grass, 37,303 tons.

\section{DAKOTA COUNTY}

Dakota County, of which Hastings is the county seat, lies on the south side of the Mississippi, opposite and immediately below St. Paul. This 
county was settled rapidly in pioneer days, owing to its situation along a navigable stream. The growth in population since 1880 has been largely in the cities and villages. Its surface was in part prairie and in part covered by a light growth of oak forest which was easily cleared.

The county drains eastward to the Mississippi River, except a few square miles in the northwest end, which drains westward to the Minnesota River. The preglacial course of the Mississippi, as indicated by the well records, was a few miles south of its present course, and its bed is but little more than 500 feet above sea level. The present river has a bed 150 to 175 feet higher, the stream being about 670 feet where it leaves the county. A considerable part of the county has an altitude between 900 and I,000 feet. The preglacial rock surface of this county, and that of neighboring parts of Washington, Goodhue, and Rice counties, was very uneven, there being isolated mesa-like uplands and buttes standing 100 to 200 feet above the surrounding lowland. A capping of limestone over soft sandstone protected the sandstone wherever it escaped erosion, while the unprotected sandstone was greatly broken down. The glacial deposits have only partially concealed the old escarpments of the mesas, and coated their table-like surfaces with a thin cover, except in the part of the county occupied by strong moraines of the red drift.

The moraines of young red drift are prominent in the northwest part of the county in the great bend of the Mississippi opposite St. Paul and Minneapolis. They are overlapped by the gray drift of the Keewatin ice field along the western edge of the county. Extensive red drift gravel plains run entirely across the county from west to east, and descend from an altitude of 900 feet or more to about 800 feet. The valleys of the Vermilion and Cannon rivers are also gravelly.

In the eastern part of the county an older red drift is extensively exposed, while in the southwestern part the old gray drift occupies the surface, except where covered with thin deposits of later drift and traversed by lines of glacial drainage from the newer drift.

A large part of the old red drift is loose-textured and gravelly, there being but a small admixture of clay. It includes a sharply ridged belt leading southeastward from Hampton nearly to the Cannon River. But as a rule its surface is nearly plane. The weathering of this drift is markedly greater than that of the young red drift; yet it seems to be of post-Kansan age, for it lies on the eroded surface of the Kansan drift, or old gray drift of the Minnesota reports.

The old gray drift contains a large amount of clayey till, but it has been leached of calcareous material to a depth of several feet, and thus 
differs from the young gray drift in which limestone pebbles are preserved nearly to the surface.

There are strips of loess in this county entirely isolated from the large loess-covered areas of southeastern Minnesota. One strip about a mile in average width rums from New Trier southeast to the southeast corner of the county. Another small loess area lies northwest of Farmington.

\section{Percentages of Classes of Land in Dakota County}

Square miles Percent

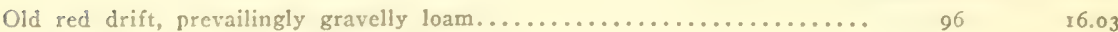

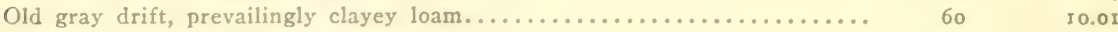

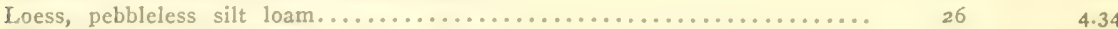

Wisccnsin red drift, stony clay loam................... I10 18.36

Wisconsin red drift outwash and glacial drainage, gravelly loam with partial

cover of silt loam ................................. II 8 .

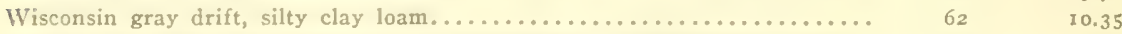

$\begin{array}{llll}\text { Alluvium and marshy bottoms along the Minnesota and Mississippi rivers.. } & 28 & 4.67\end{array}$

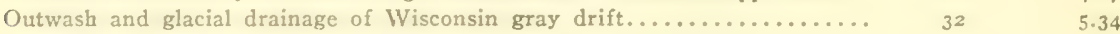

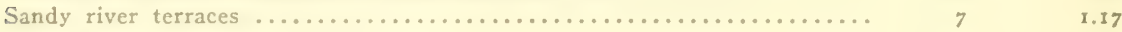

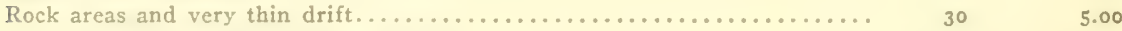

Swamps and bogs (outside river valleys)..................... $30 \quad 5.00$

$599 \quad 99.99$

Farm and Crop Data for Dakota County from Census of 1910

Rural population 11,249 or 18.7 per square mile

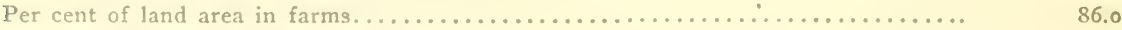

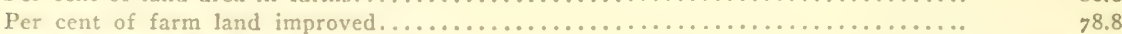

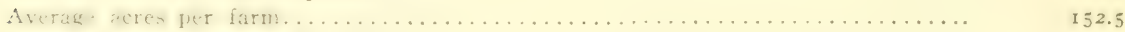

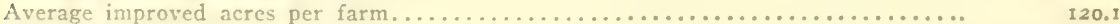

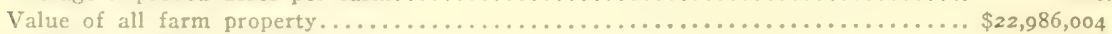

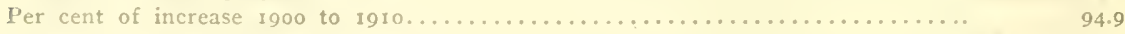

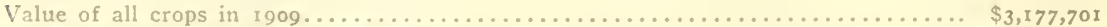

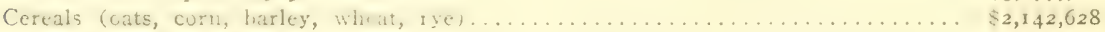

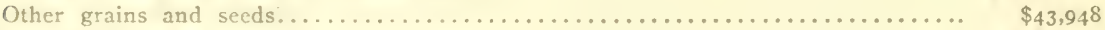

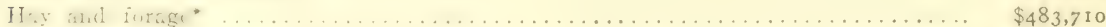

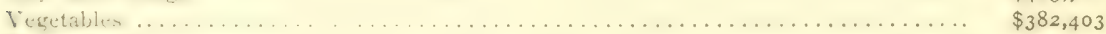

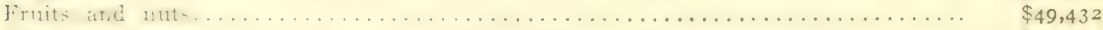

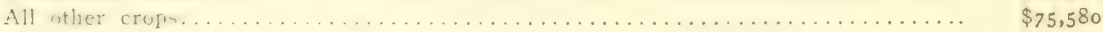

* Tame grass, 51,335 tons; wild grass, I I, 047 tons.

\section{GOODHUE COUNTY}

Goodhue Comnty borders the Mississippi River in southeastern Minnesota, with Red Wing as the county seat. Like Dakota County it was settled at an carly dite, the settlements being at first on the gravel terraces along the Mississippi and its tributaries, and soon after on the uplands.

The drainage is all eastward to the Mississippi, the north part being drained chiefly by Cannon River, and the south part by Zumbro River. The uplands are gently undulating to rolling, and are of the drainage erosion type, for this county lies outside the limits of the young or Wisconsin drift, and there has been developed a broad dendritic drainage in 
the old gray drift. Toward the eastern side of the connty, howerer, the streams drop down into the deep preglacial drainage.

The uplands maintain a height of about I, IOO feet clear out to the Mississippi in the district below Red IVing, but are somewhat lower in the north part of the county. The southwest part of the county rises to I,200 or I,250 feet, but as the drift there is about Ioo feet thick, the rock surface is about the same altitude as at the bluffs of the Mississippi. The bluffs are very precipitous, being formed largely of Paleozoic limestone, and rise 300 to 400 feet or more above the Mississippi and the lower courses of its tributaries. The Mississippi below Red Wing is expanded into Lake Pepin with an altitude of $66+$ feet at low water, and about 680 feet at high water stages.

Along the Mississipyi and its main tributaries, Cannon River and Zumbro River, there are conspicuous deposits of fine gravel, laid down by glacial waters which escaped from the edge of the ice when it covered the upper parts of these valleys. Along the Mississippi the outlet of Lake Agassiz swept away a large part of this glacial gravel. The gravel was carried by the glacial waters into lowlands in and east of Red Wing that are outside the present course of the Mississippi but which open into the Mississippi at either end. The gravel filling reached about 800 feet above sea level in the vicinity of Red Wing, or I40 feet above Lake Pepin.

The northeast part of the county was forested, but the uplands of the central and southwest parts were prairie. A large part of the uplands has a capping of loess over the old gray drift. That in the forested part is of brown color, while that in the prairie is a dark, nearly black silt loam. The brown phase is classed by the Burcau of Soils as Knox silt loam, while the dark phase is called Marshall silt loam. ${ }^{1}$

A large part of the prairie portion of Goodhue County has no capping of loess, and the old gray drift is at the surface. It is largely a clayey till, and is classed by the Bureatr of Soils as Carrington loam, silt loam, and fine sandy loam. In a few places gravelly knolls appear, the most conspicuous belt being immediately south and west of Zumbrota. These are classed as Miami silt loam, gravel hill phase. In some cases the slopes of these gravel hills have a capping of loess which throws the soil into the Knox series. About six square miles, however, were found to be gravelly at the surface. The gravel contains much limestone; in some cases this has been leached ont to a depth of only a few inches, while in other cases it has been leacherl to a depth of several fect, leaving only the cherty parts to indicate its former presence.

1 Soil Survey of Goodhue County. Field operations of the Burean of Soils 19:3. 
There are a few square miles of old red drift exposed in the northern part of the county northwest of Welch. This is looser textured and more stony than the old gray drift which it overlies. But the Bureau of Soils classes this drift in the Carrington series.

The glacial gravel and sand of Wisconsin age is classed as Waukesha loam, gravelly sandy loam, etc., to correspond with the variations in coarseness of the soil.

The low bottoms which are more or less subject to overflow are classed as Wabash silt loam, loam, or fine sandy loam, to correspond with variations in texture. The name Wabash silt loam, colluvial phase, is applied to material that is in process of transportation down small tributaries and gentle slopes into the main valleys. This often contains bowlders and other coarse material.

The rough stony land embraced in the steep bluffs is estimated by the Bureau of Soils to include 4.8 per cent of the county, but much of this is suitable for pasture, as it carries soil and disintegrating lime material that gives grasses a good growth.

The loess soil of this region was for many years devoted to wheat growing, but of late barley has taken the place of wheat, while there has been a gradual change to diversified farming.

\section{Area of Different Soils in Goodhue County (from Bureou of Soils Report)}

Acres

Knox silt loam (loess)

Wabash silt loam (alluvium)

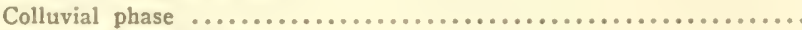

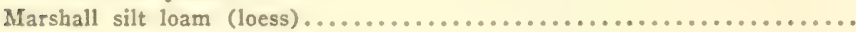

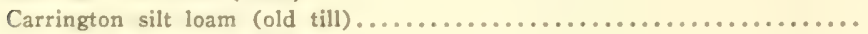

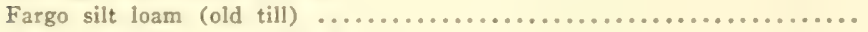

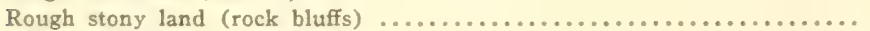

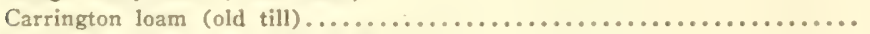

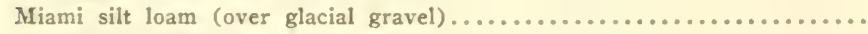

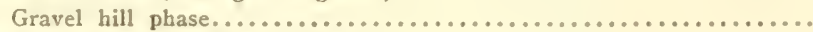

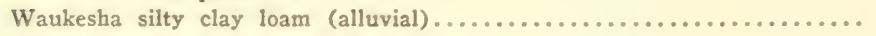

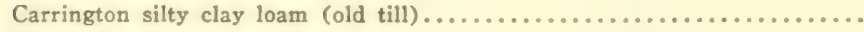

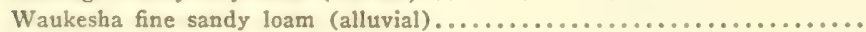

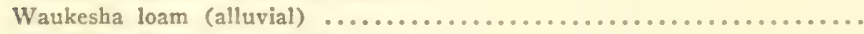

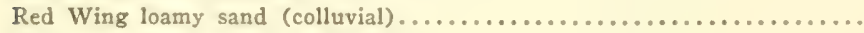

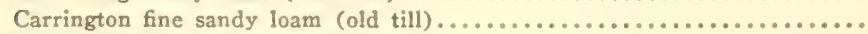

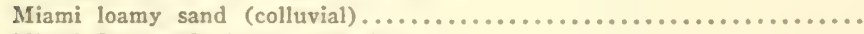

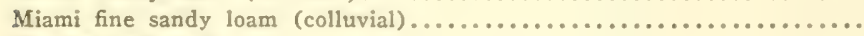

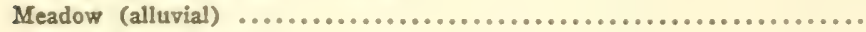

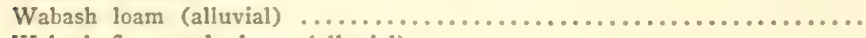

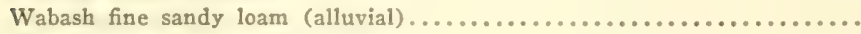

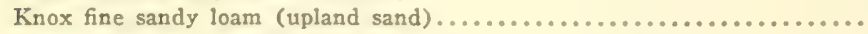

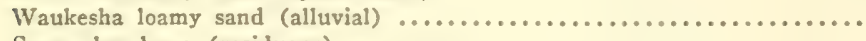

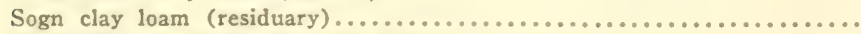

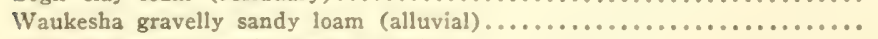

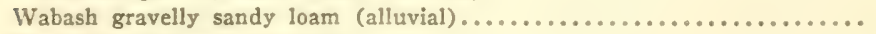

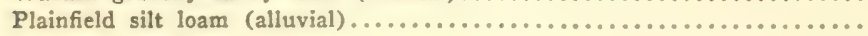

\begin{tabular}{rr}
211,200 & 43.0 \\
19,648 & 4.0 \\
25,344 & 5.2 \\
36,864 & 7.5 \\
32,448 & 6.6 \\
24,640 & 5.0 \\
23,552 & 4.8 \\
21,504 & 4.4 \\
16,768 & 3.4 \\
4,032 & 0.8 \\
15,360 & 3.1 \\
13,696 & 2.8 \\
7,552 & 1.5 \\
5,312 & 1.1 \\
5,184 & 1.1 \\
4,672 & 1.0 \\
4,224 & 0.9 \\
4,160 & 0.9 \\
3,136 & 0.6 \\
2,112 & 0.4 \\
2,048 & 0.4 \\
2,048 & 0.4 \\
1,600 & 0.3 \\
1,472 & 0.3 \\
1,088 & 0.2 \\
960 & 0.2 \\
256 & 0.1 \\
\hline 190,880 & 100.0
\end{tabular}




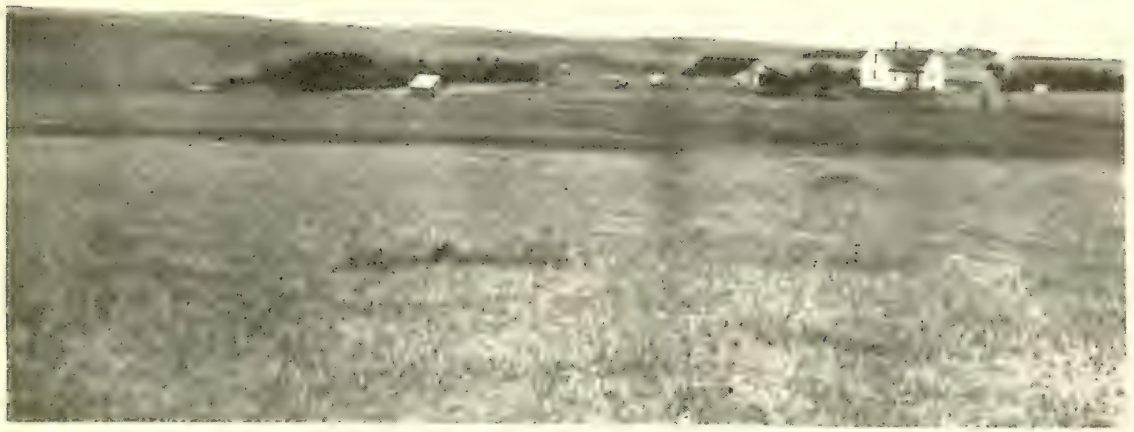

A. SLOPE OF TIIE COTEAU INS PRIIRIES XEAR CANBY, GRAY DRIFT MORAINE

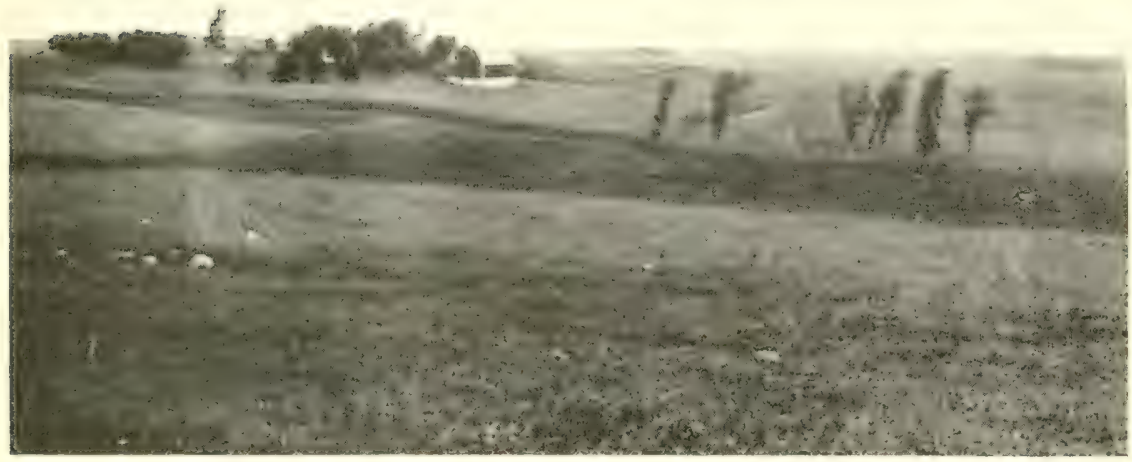

B. ERONED UPLAND IN OLD GR.IY (KANSAN) DRIFT NORTHEAST OF ZUMBROTA

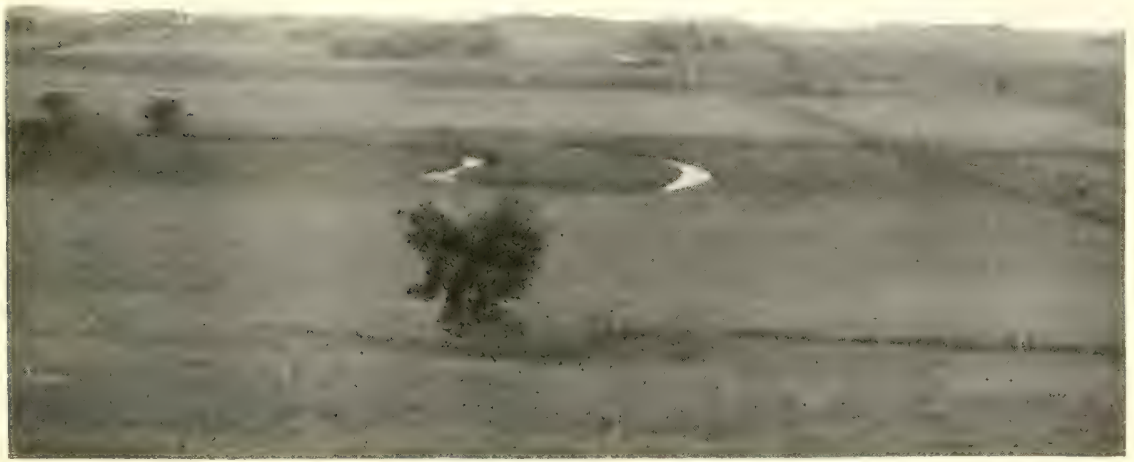

C. BROAD VALLEY CUT IN OLD GRAY (KANSAN) DRIFT WEST OF KENYON 

Farm and Crop Data for Goodhue County from Census of 1910

Rural population 57,403 or 22.7 per square mile

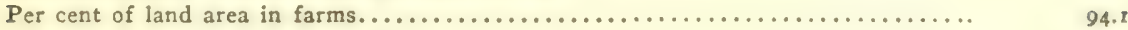

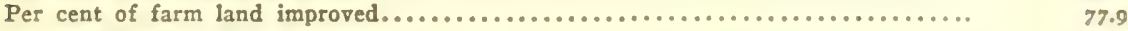

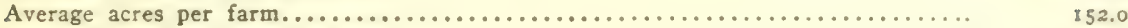

Average improved acres per farm................................. I 8.4

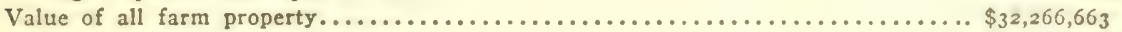

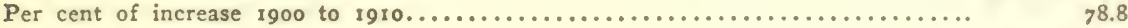

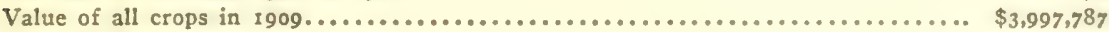

Cereals (barley, oats, corn, wheat, rye).......................... $\$ 2,944,258$

Other grains and seeds....................................... \$196,940

Hay and forage ............................................. $\$ 618,554$

Vegetables .............................................. \$roo,287

Fruits and nuts........................................... \$39,210

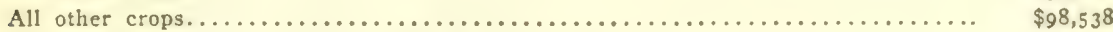

- Tame grass 100,403 tons; wild grass 8,627 tons.

RICE COUNTY

Rice County, with Faribault as its county seat, is located in southeastern Minnesota. The land area is 495 square miles, and there is an additional 2I square miles in lakes. The greater part of the county is drained by Cannon River northeastward to the Mississippi at Red Wing, but the southeast part is drained eastward by the Zumbro River. The northwest corner is drained northward to the Minnesota River.

About roo square miles along the eastern side of the county lie outside the limits of the Wisconsin drift, and this old drift area comprises most of the prairie portion of the county. It also includes the highest land in the county which is found in the southeast part and reaches an altitude of nearly I,300 feet. The western half of the county, even where occupied by sharp morainic ridges, is largely between I,000 and $\mathrm{I}, \mathrm{IOO}$ feet. The lowest land in the county is in the valley of Cannon River, which falls to about 900 feet at Northfield on the north edge of the county.

The old drift has an undulating surface produced by broad wide open drainage lines. These are excavated in the drift, except in the northeast corner of the county, where they drop into preglacial valleys and lowlands. In that part of the county there are a few flat-topped mesas in which limestone caps the soft St. Peter sandstone. The lowlands around these mesas are filled with an old gravel covered by a few feet of black loam soil. The mesas are generally covered to a depth of a few feet by a clayey till. The old gray drift of the eastern part of the county is chiefly a pebbly clay loam, classed by the Bureau of Soils as Carrington loam, and Carrington silt loam." There are small loess-covered areas in it occupying about 8 square miles in the district between Northfield and Nerstrand. This is classed as Marshall loam by the Bureau of Soils. 
Area of Different Soils in Rice County (from Bureau of Soils Report)

\begin{tabular}{|c|c|c|}
\hline & Acres & Per cent \\
\hline Carrington loam (chiefly moraine). & 84,096 & 26.3 \\
\hline 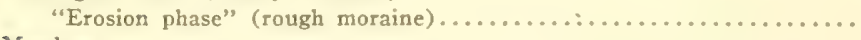 & 39,296 & 12.3 \\
\hline 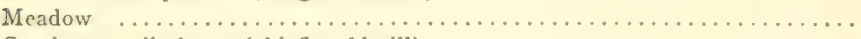 & 40,832 & 12.8 \\
\hline 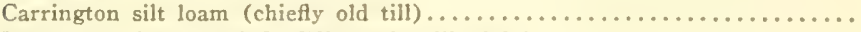 & 38,144 & I I.9 \\
\hline 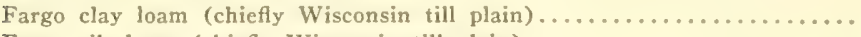 & 24,832 & 7.8 \\
\hline 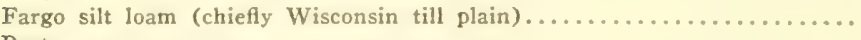 & 22,720 & $7 \cdot 1$ \\
\hline 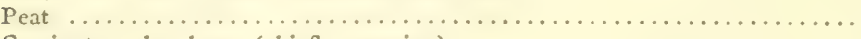 & 16,320 & 5.1 \\
\hline 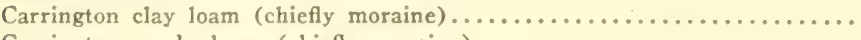 & 12,544 & 3.9 \\
\hline 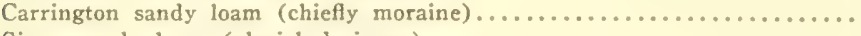 & 11,840 & 3.7 \\
\hline 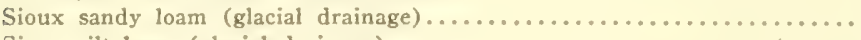 & 10,752 & 3.4 \\
\hline 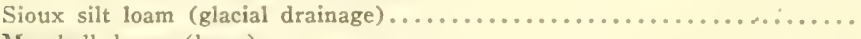 & 7,744 & 2.4 \\
\hline 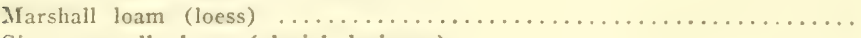 & 4,992 & 1.5 \\
\hline 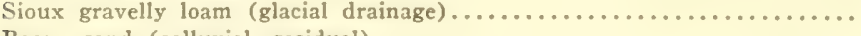 & 2,304 & 0.7 \\
\hline 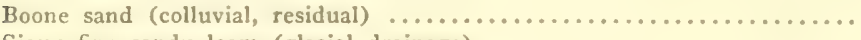 & 2,240 & 0.7 \\
\hline 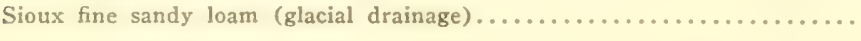 & 1,344 & 0.4 \\
\hline & 20,000 & \\
\hline
\end{tabular}

Farm and Crop Data for Rice County from Census of 1910

Rural population $11,8 \geq_{3}$ or 24 per square mile

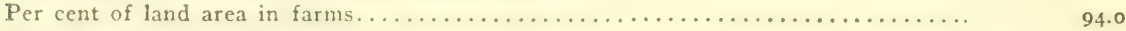

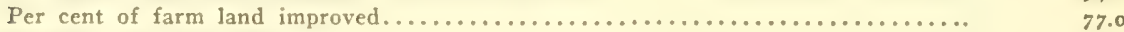

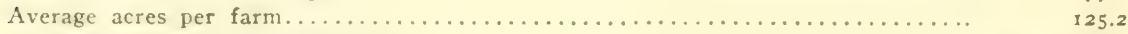

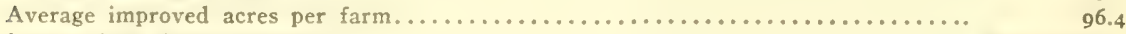

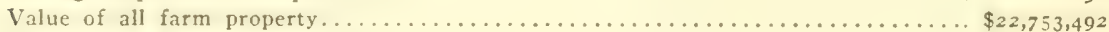

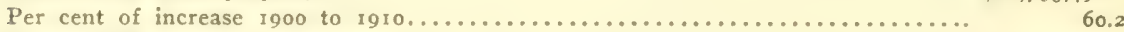

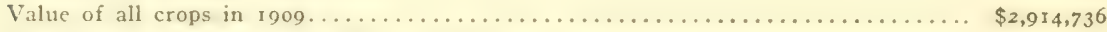

Cereals (oats, wheat, corn, barley, rye)....................... \$2,110,966

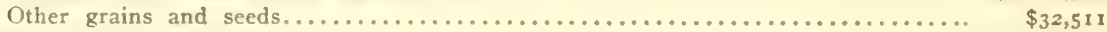

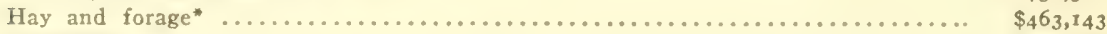

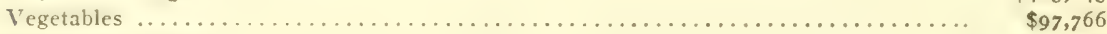

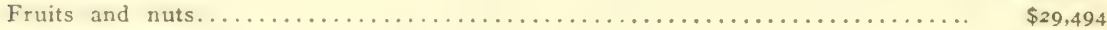

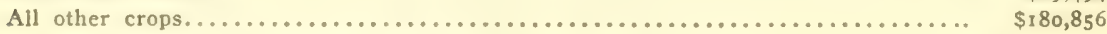

* Tame grass 51,260 tons; wild grass 35,628 tons.

A large part of Rice County is occupied by the system of moraines which were formed on the east side of the Keewatin ice field and run north to south across the county. Among the morainic ridges and knolls there are small till plains, but the moraines are woven together in an intricate manner. The soil of the moraines is classed in the Carrington series by the Bureau of Soils, while the till plains are chiefly Fargo silt loam, and Fargo clay loam, but part of the till plain is in the Carrington series. There are numerous peat bogs inclosed among the morainic knolls and ridges, and the depressions, when not peaty, have usually a darker colored soil than the bordering higher and better drained land.

The young gray drift overrode the moraines of the red drift in northern Rice County but made so heavy a deposit that the red drift is completely concealed. Red drift material, however, is found involved in the gray, either in masses or mixed more thoroughly. The red drift may in some cases have been carried farther south than its original position. Such seems to have been the case in an exposure noted on the Rock 
Island Railroad at the north line of Cannon City Township, five miles north of Faribault.

The glacial outwash and glacial drainage deposits are classed by the Bureau of Soils as Sioux gravelly loam and Sioux sandy loam. The silt covered old gravel, in the northeast part of the county, is classed as Sioux silt loam.

\section{LE SUEUR COUNTY}

Le Sueur County is situated on the east side of the north flowing part of the Minnesota River in southern Minnesota, with Le Sueur Center as the county seat. The greater part of the county drains northwestward into the Minnesota, but the southeast corner is drained eastward by Cannon River to the Mississippi.

The eastern edge of the county is strongly morainic, and a prominent morainic spur extends westward past Elysian about 6 miles farther than the rest of the moraine. Between the moraine and the Minnesota valley is a till plain Io to I 5 miles wide with scarcely any knolls, but with numerous basins and small lakes. A line of glacial drainage heading at Elysian leads eastward through the moraine and down the Cannon valley.

The morainic area as well as the till plain is largely composed of clayey till with a pebbly clay loam soil. But in the morainic spur near Elysian there is a large amount of gravelly, loose-textured drift.

The Minnesota valley is about 250 feet deep along the border of this county, but part of it is filled with glacial drainage deposits of sandy gravel, the highest of which stand about I50 feet above the stream. These gravelly plains were occupied in part by prairie, but the remainder of the county was covered with hardwood forest. The outlet of Lake Agassiz removed a large part of the glacial gravel, and in places exposed rock ledges which appear along the valley up to a height of 50 to 75 feet or more above the stream.

\section{Percentages of Classes of Land in Le Sueur County}

\begin{tabular}{|c|c|c|}
\hline & Square miles & Per cent \\
\hline Gravel hills and stony loam in moraine...... & 24 & 5.25 \\
\hline 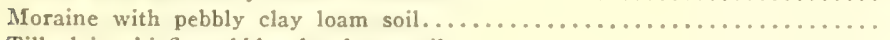 & 102 & 21.88 \\
\hline 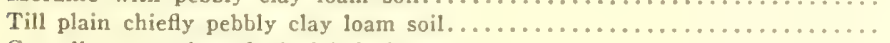 & 280 & 60.08 \\
\hline 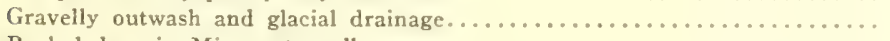 & 25 & 5.38 \\
\hline 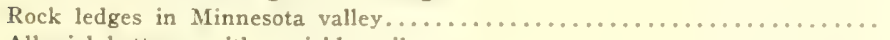 & 8 & 3.71 \\
\hline 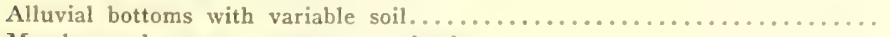 & 17 & 3.65 \\
\hline 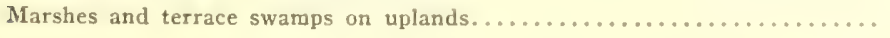 & 10 & 2.15 \\
\hline & 466 & $100 . \mathrm{C}$ \\
\hline
\end{tabular}

Farm and Crop Data for Le Sueur County fron Census of 1910

Rural population II,347 or 24.3 per square mile

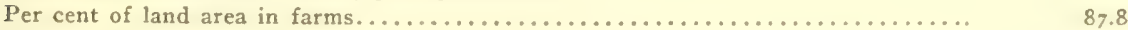

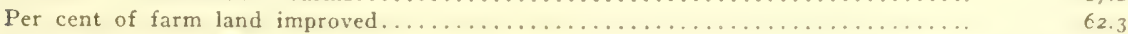

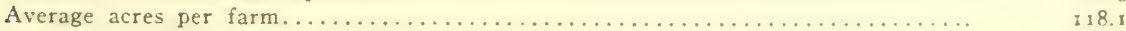


Farm and Crop Data for Le Sueur County (Continued)

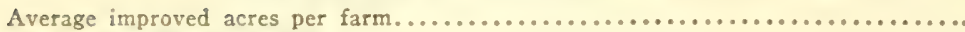

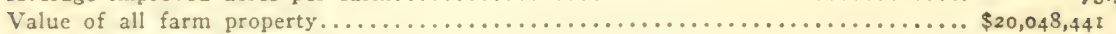

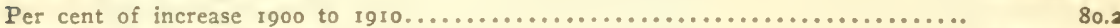

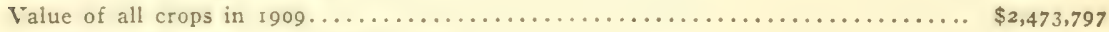

Cereals (wheat, corn, oats, barley, rye)......................... \$2,004,730

Other grains and seeds....................................... \$3,944

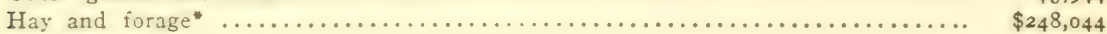

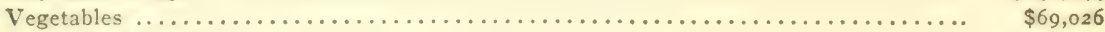

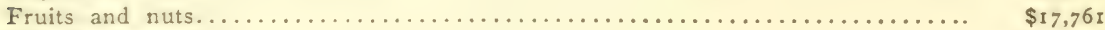

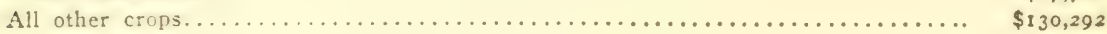

* Tame grass, 3 r, 353 tons; wild grass, 35,664 tons.

\section{NICOLLET COUNTY}

Nicollet County is situated on the north side of the great bend of the Minnesota River in southern Minnesota, with St. Peter as its county seat. The drainage is all south or east to the Minnesota, but in much of the county natural drainage lines are poorly developed, and it has been necessary to extend ditches over such areas. There are several shallow lakes on the uplands occupying about 20 square miles, around which is marshy land with an additional Io square miles. Ditching has, however, reduced the marshes and wet areas very materially.

The county is nearly all a prairie till plain with rich black loam soil and pebbly clay loam subsoil. A morainic strip with two somewhat distinct ridges or members leads across the western part of the county from Clear Lake past Klossner to the Minnesota valley at Cortland. The moraine has some knolls of gravel, but always with clay till surface.

The Minnesota valley is cut to a depth of about 200 feet below the bordering till plain. Near St. Peter, and also near Cortland, there is a wide remnant of a glacial gravel deposit, but generally the low bottom lands extend back to the bluffs. The glacial river that was the outlet of Lake Agassiz uncovered rock ledges in the east part of the county, and between Cortland and New Ulm.

\section{Percentages of Classes of Land in Nicollet County}

\begin{tabular}{|c|c|c|}
\hline \multicolumn{3}{|c|}{ Square miles } \\
\hline 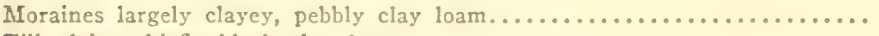 & 40 & 9.03 \\
\hline 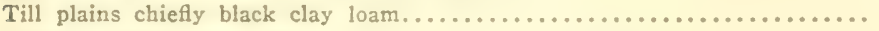 & 330 & 74.49 \\
\hline 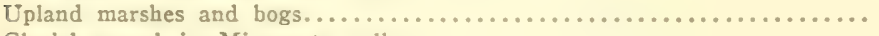 & 10 & 2.25 \\
\hline 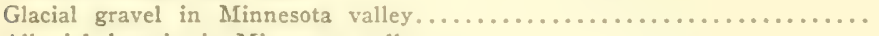 & 9 & 2.03 \\
\hline 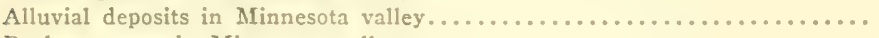 & 50 & $I 1.28$ \\
\hline 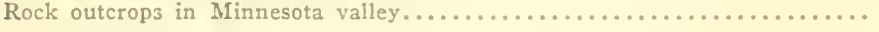 & 4 & 0.9 I \\
\hline & 433 & \\
\hline
\end{tabular}

Farm and Crop Data for Nicollet County from Census of 19 to

Rural population 7,929 or 17.9 per square mile

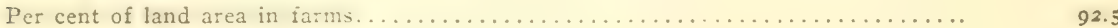

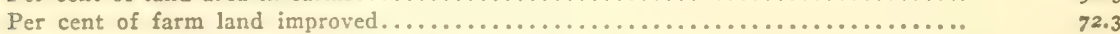

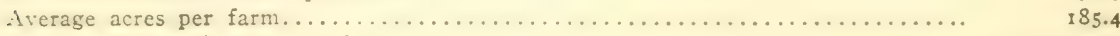

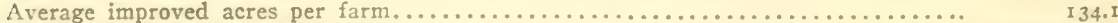

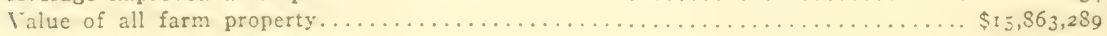


Farm and Crop Data for Nicollet County (Continued)

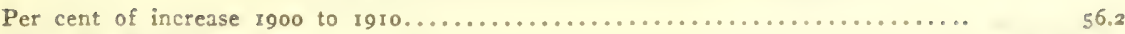

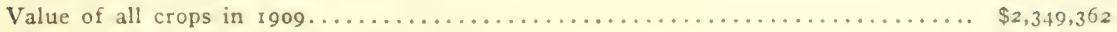

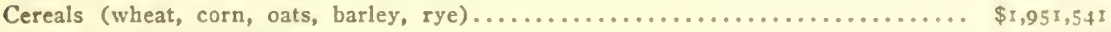

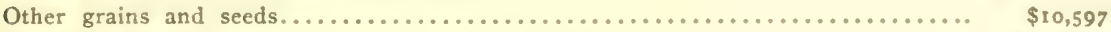

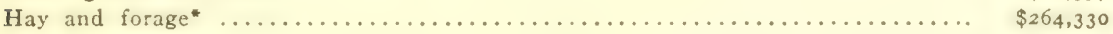

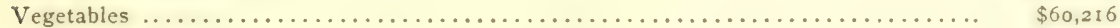

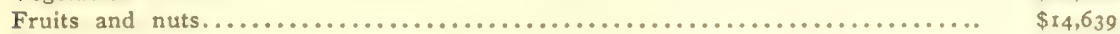

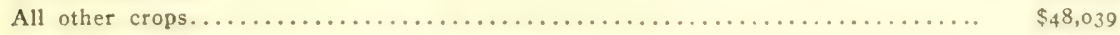

- Tame grass, 17,6 ro tons; wild grass, 54,967 tons.

\section{BROWN COUNTY}

Brown County, of which New Ulm is the county seat, lies on the south side of the Minnesota valley in southern Minnesota. The drainage is all eastward into the Minnesota chiefly through Cottonwood and Little Cottonwood rivers. From an altitude of over $\mathrm{I}, 200$ feet in the southwest corner of the county, the upland plain slopes gently northeastward to about $\mathrm{I}, 000$ feet at the bluff of the Minnesota River. The river is in a valley 200 feet deep, and falls from 804 feet at the west line to about 780 feet at the east line of the county.

There are sharp moraines with well-defined outwash plains and lines of glacial drainage crossing the southwest part of the county. There is also a moraine traversing the central part of the county from northwest to southeast. But the greater part of the county is a prairie till plain with rich black loam soil and pebbly clay loam subsoil. Forest is confined to narrow strips along the Cottonwood and Minnesota valleys. Gravel knolls occur here and there on the plain, and they are numerous in the moraines. The gravelly outwash plains of the southwest part of the county are continued eastward in lines of glacial drainage which form a network of channels leading across from the Little Cottonwood to the Watonwan River. Their courses were determined by the edge of the ice, and not by the most rapid slope of the land. The present streams are more nearly adjusted to the general slope of the country. The Minnesota valley has small remnants of a filling with glacial gravel to a height of over 100 feet above the river. The city of New Ulm stands on one of these remnants.

\section{Percentages of Classes of Land in Brown County}

\begin{tabular}{|c|c|c|}
\hline \multicolumn{2}{|c|}{ Square miles } & Per cent \\
\hline 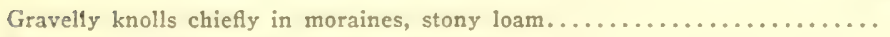 & 8 & 1.30 \\
\hline 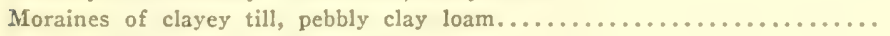 & 75 & 12.25 \\
\hline 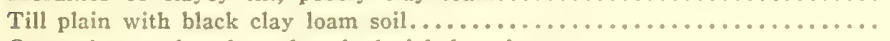 & 460 & 75.16 \\
\hline 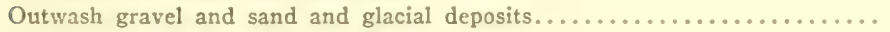 & 40 & 6.53 \\
\hline 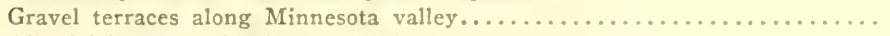 & 2 & 0.32 \\
\hline 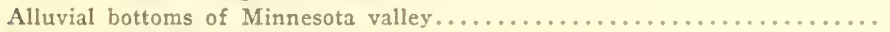 & 24 & 3.92 \\
\hline 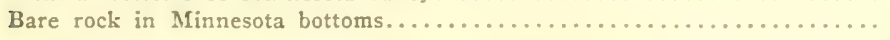 & 3 & 0.49 \\
\hline & 612 & 99.97 \\
\hline
\end{tabular}


Farm and Crop Data for Brozun County from Census of Igio

Rural population ro,oro or 16.35 per square mile

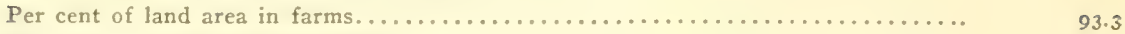

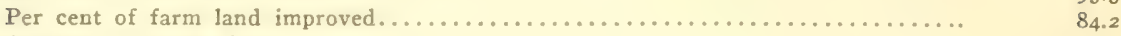

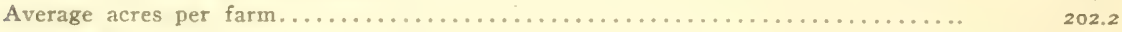

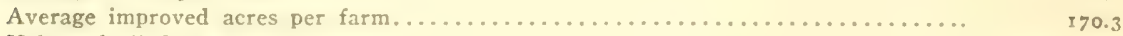

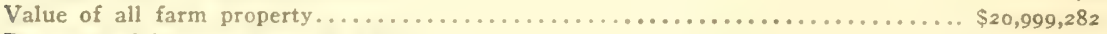

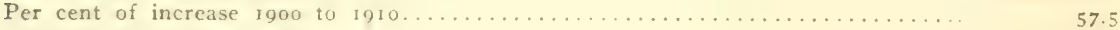

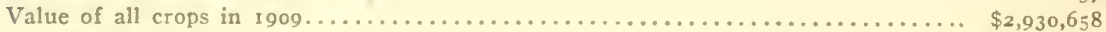

Cereals (wheat, corn, oats, barley, rye) ...................... \$2,445,529

Other grains and seeds................................... $\$ 29,067$

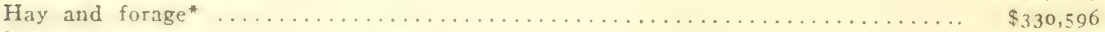

Vegetables . . . . . . . . . . . . . . . . . . . . . . . . . . . $\$ \ldots \ldots, 266$

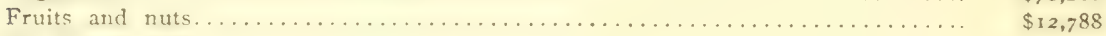

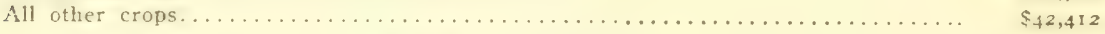

* Tame grass, 20,657 tons; wild grass, 71,440 tons.

REDWOOD COUNTY

Redwood County is situated on the south side of the Minnesota valley in southern Minnesota, with Redwood Falls as the county seat. The drainage is all eastward to the Minnesota River, chiefly through Redwood and Cottonwood rivers. The county is largely a plain standing between I,O0O and I,200 feet, but the southwest corner rises to about I,400 feet. The Minnesota valley is cut to a depth of 200 feet below the bordering plain, the river being 842 feet at the western, and 804 feet at the eastern limits of the county.

There are several moraines formed along the south edge and southeast end of the Keewatin ice field as it was melting back across the plain that borders the Minnesota River. One morainic belt is in the southwest corner of the county ; another follows the north side of the Cottonwood, and another the north side of the Redwood valley. This last moraine splits into three narrow ridges that run southeastward through the eastern part of the county. There is also a later moraine in the extreme northwest corner of the county. The moraines are usually a clayey till, but in places grave! knolls become conspicuous. This is notably the case in the slender ridges in the east part of the county. There is a prominent strip of gravel knolls and ridges immediately east and south of Revere, which trends southwestward toward a moraine in Cottonwood County, instead of paralleling the course of moraines of this region. It is not, however, a definite gravel or esker ridge, but has much irregularity of form and of structure, for considerable till is included with the gravel.

Glacial drainage seems to have been rather weak along the border of the moraines, and deposits of sand and gravel are scanty. It is probable that the water was ponded in places along the edge of the ice during the development of some of the moraines. The plains bordering the moraines have a rich black clay loam soil, as this was a prairie region. 
The moraines have a brown clay loam soil where most prominent, but the parts with a gentle slope have a darker soil.

Rock outcrops are conspicuous along the Minnesota River and up Redwood valley as far as Redwood Falls. The granite is in places capped by cretaceous deposits in the river bluffs, but is generally swept bare in the valleys. It rises in places fully $I 00$ feet above the stream, and at Redwood Falls attains an altitude of nearly 200 feet above the Ninnesota River, or I,000 feet above sea level. The Minnesota valley has in this county but little good farm land because of the extensive outcrops of ledges, and because portions of it are subject to overflow.

Percentages of Classes of Land in Redwood County

Square miles Per cent

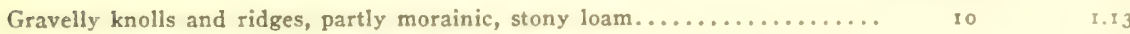

Clayey moraine, brown to black pebbly clay loam.................. ${ }_{150} \quad{ }_{17.03}$

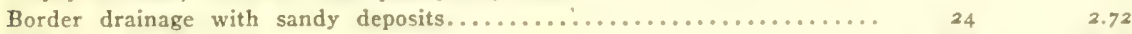

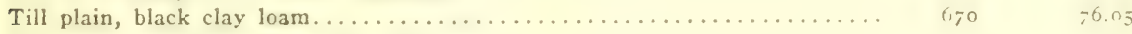

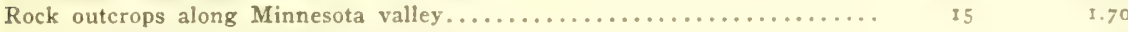

Alluvial deposits along Minnesota valler......................... $32 \quad 1.36$

$88 \mathrm{I} \quad 99.99$

Farm and Crop Datc for Redwood County front Census of 1950

Rural population 12,760 or 14.5 per square mile

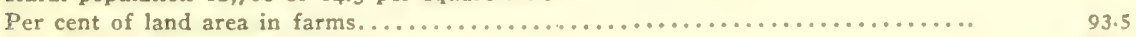

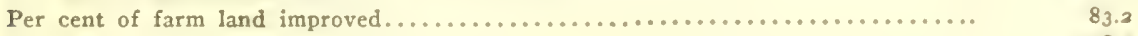

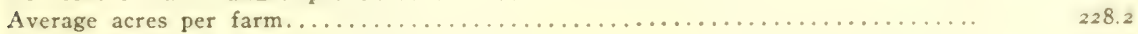

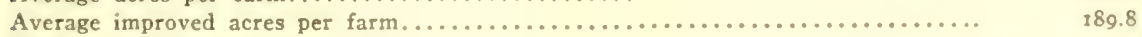

Value of all farm property................................... \$30,23s,266

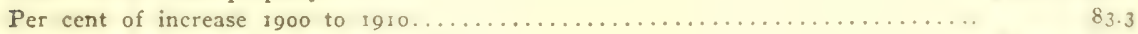

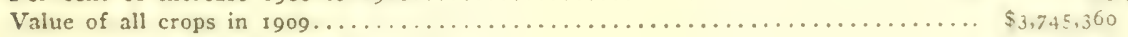

Cereals (oats, corn, wheat, barley, rye)............................ \$3,258,279

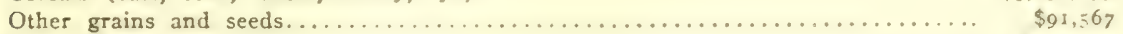

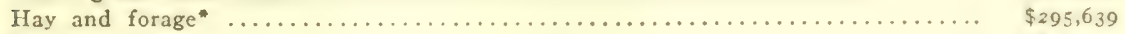

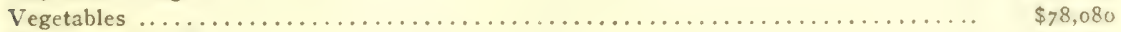

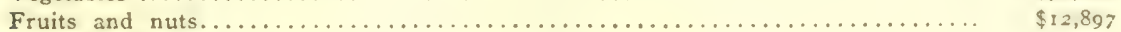

All other crops..................................... $\$ 8,898$

- Tame grass, 31,8I9 tons; wild grass, 59,1 6 tons.

\section{LYON COUNTY}

Lyon County is located in the southwest part of the state, with Marshall as the county seat. The drainage is all eastward into the Minnesota River, mainly through Redwood and Cottonwood rivers. A few townships in the southwest part are on the slope of the Coteau des Prairies with an altitude ranging from 1,750 feet down to about $I, 300$ feet. The remainder of the county stands mainly between $I, 100$ and I,300 feet, and slopes gradually northeastward.

A prominent morainic system which was formed on the southwest side of the Keewatin ice field lies across the southwest part of the county, its several constituent members being ranged one below another on the slope of the Coteau des Prairies. Weaker moraines across the 
northeast part of the county run from northwest to southeast. One of them passes through Marshall and others cross the northeast corner of the county. All the moraines, whether weak or strong, are composed mainly of clayey till, and have a brown pebbly clay loam soil. The till plains which lie between the moraines have a black clay loam soil with pebbly clay loam subsoil.

There is remarkably little outwash gravel connected with the moraines in this county. A few gravel knolls occur near Balaton, and others near Russell. There are definite border drainage channels along the south side of the weak moraines in the northeast part of the county, which are in places covered to a slight depth with sand and fine gravel.

Percentages of Classes of Land in Lyon County

Square miles Per cent

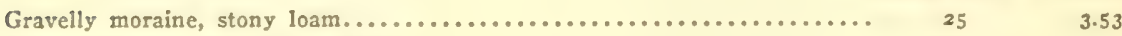

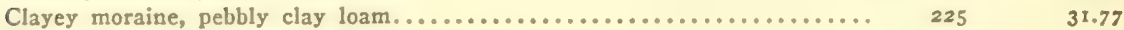

Till plain chiefly black clay loam.......................... $390 \quad 55.09$

Outwash and sandy glacial drainage deposits...................... $30 \quad 4.24$

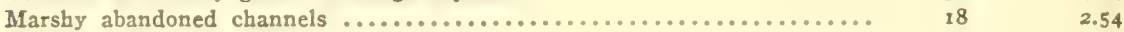

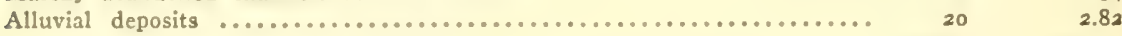

90899

Farm and Crop Data for Lyon County from Census of toro

Rural population 9,064 or 12.8 per square mile

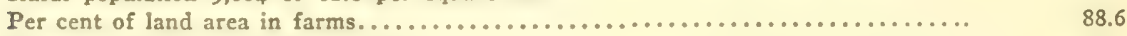

Per cent of farm land improved.................................. 85.7

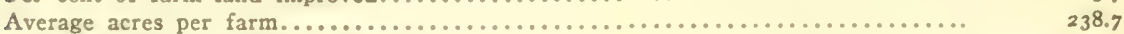

Average improved acres per farm................................ 204.6

Value of all farm property..................................... \$23,059,304

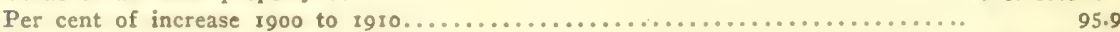

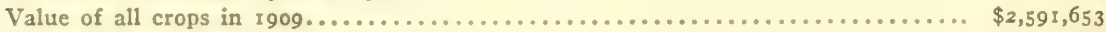

Cereals (oats, corn, barley, wheat, rye)........................ $\$ 2,132,612$

Other grains and seeds........................................ \$90,96I

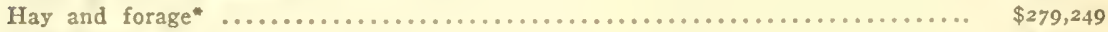

Vegetables ...................................................... \$59, $\$$

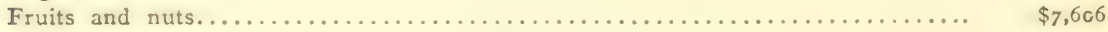

All other crops............................................ \$2 , 300

- Tame grass, 31,439 tons; wild grass, 32,997 tons.

\section{LINCOLN COUNTY}

Lincoln County is situated on the west border of the state in southwestern Minnesota, and embraces a land area of 535 square miles, in addition to which there are I9 square miles in lakes. The county is crossed from the northwest to southeast by the crest of the Coteau des Prairies. The northeast slope of the Coteau is drained to the Minnesota, while the southwest is drained to the Big Sioux and thence to the Missouri River.

The crest of the Coteau is a moraine that leads southeastward through the southwest part of the county past the south end of Lake Benton. This moraine has three deep notches in it within the limits of this county, 
which permit drainage from its inner border to pass through it into the Sioux River system. The altitude of the highest points on the moraine is nearly 2,000 feet, and there are several square miles standing above I,900 feet. The bordering till plains on each side of the moraine are also very elevated, much of their area in this county being above I,SoO feet. Glacial drainage lines led from this moraine southwestward into South Dakota to the Big Sioux valley.

The northeast half of Lincoln County is largely morainic, there being only narrow till plains between conspicuous ridges. These ridges are arranged one below another on the slope of the Coteau, the altitude of the outer ones being $I, 700$ to $I, 800$ feet, and of the inner I,400 feet or less.

The strong moraines of this county include much loose-textured cobbly and bowldery drift, with a stony loam soil, but there are large sections with clayey till and only a moderate number of stones. The till plains have a pebbly clay loam soil.

\section{Percentages of Classes of Land in Lincoln County}

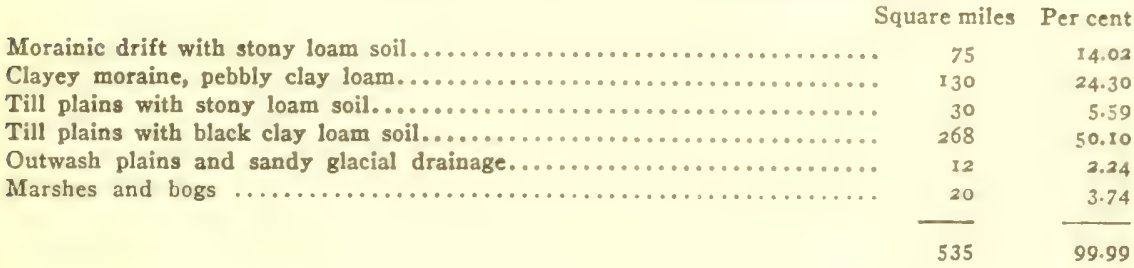

Farm and Crop Data for Lincoln County from Census of IoIO

Rural population 7,429 or 14 per square mile

Per cent of land area in farms.................................... 89.4

Per cent of farm land improved................................... $8{ }_{1.4}$

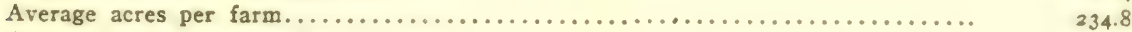

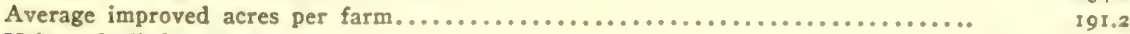

Value of all farm property.................................. \$15,729,215

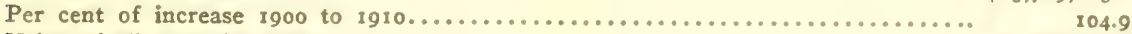

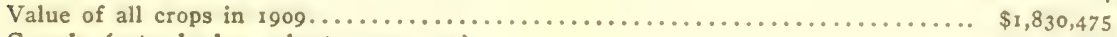

Cereals (oats, barley, wheat, corn, rye)......................... \$1,333,054

Other grains and seeds.................................... \$194,437

Hay and forage .......................................... \$260,027

Vegetables ........................................................ $\$ 37,860$

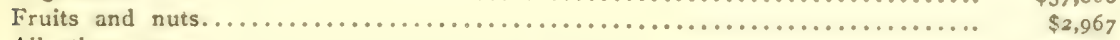

All other crops................................................. \$2, 130

- Tame grass, 32,203 tons; wild grass, 28,538 tons.

\section{PIPESTONE COUNTY}

Pipestone County is situated on the west border of southwestern Minnesota with Pipestone as the county seat. The drainage is nearly all southwestward to the Big Sioux River, but the northeast corner drains northeastward to the Minnesota River. The crest of the Coteau des Prairies forms the divide and is followed by the highest moraine of the 
young gray Keewatin drift across the northeast part of the county. The southwestern part of the county to the west and south of Pipestone City lies outside the limits of the Wisconsin drift.

The young gray or Wisconsin drift border is not marked by a continuous moraine in southwestern Minnesota, but has here and there a knolly or slightly ridged surface. The drift for several miles back from the border veneers the slopes of the eroded surface of the old gray or pre-Wisconsin drift. The present drainage lines follow in a general way the courses opened by the interglacial streams. This area as far back as the prominent moraine on the Coteat des Prairies is free from lakes, and nearly all the surface is well drained. But from the crest of the Cotean northeastward the later drift completely filled the interglacial valleys, except perhaps great depressions such as that occupied by Lake Benton, and its deposits are so irregular and uneven that undrained basins and lakes are common features.

Outside the limits of the Wisconsin drift is a greatly eroded till area with broad valley bottoms and gentle valley slopes. This has a scanty coating of wind-drifted silt-loam, but usually the till is within a few inches of the surface.

There is a thin silt deposit covering the Wisconsin or younger drift 111 !laces to a depth of $\mathrm{I}$ to 3 feet which seems to have been brought in from loess-covered areas on the southwest. This is somewhat more complact than the silt cover on the older drift, thus making a clay loam rather than a silt loam soil.

There are small areas of bare quartzite in the vicinity of Pipestone and southward into Rock County. The quartzite, however, is generally covered with a few feet of drift, sufficient for productive farming. The bare areas are only a few acres each, and the entire exposure probably does not exceed 2 square miles. There is about Ioo square miles in which the quartzite is known to underlie the drift, usually within a depth of a few feet. This is mainly within the older drift area, but the north part lies within the limits of the younger drift.

\section{Percentages of Classes of Land in Pipestone County}

\begin{tabular}{|c|c|}
\hline & Square miles \\
\hline 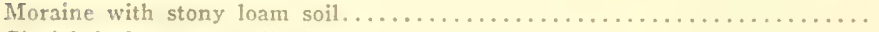 & 23 \\
\hline 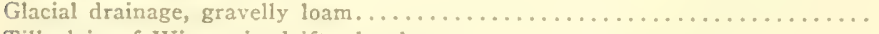 & 36 \\
\hline 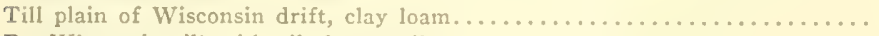 & 308 \\
\hline 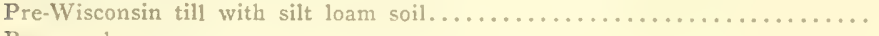 & I 00 \\
\hline 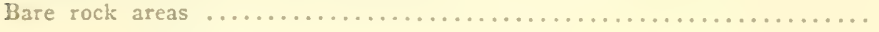 & 2 \\
\hline
\end{tabular}

Farm and Crop Data for Pipestone County from Census of roro

Rural population 5,II6 or II per square mile

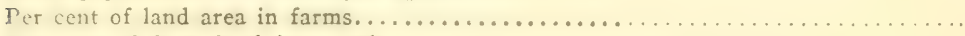

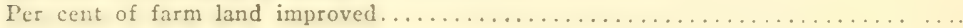


Farm and Crop Data for Pipestone County (Continued)

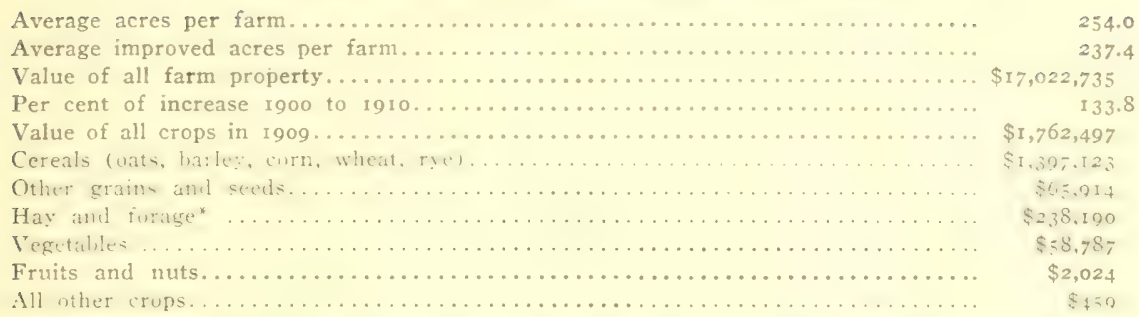

* Tame grass, 39,410 tons; wild grass, I0,585 tons.

MIURRAY COUNTY

Iurray County, of which Slayton is the connty seat, is located in the southwest part of the state, and has a land area of $70+$ square miles, with about I6 square miles additional in small lakes. The drainage of this connty is in three different systems, the northeast part being drained northeastward to the Minnesota, the central and southeast parts southeastward by the Des Moines River, and the southwest part southwestward to the Big Sioux River.

The crest of the Coteau des Prairies runs through the western part of the comnty, and is followed by a strong moraine. Parts of the moraine rise above $\mathrm{I}, 900$ feet, and much of it above $\mathrm{I}, 800$ feet, but there is a gap in it at Chandler which is only 1,650 feet. A few square miles on the east side of this moraine drain westward thromgh this gap toward the Big Sioux River. The drainage of the eastern slope is chiefly to the Des Moines River. In the southwest part of the county the moraine just referred to becomes double and continues so southeastward into Iowa. The inner member makes a sharp loop northeastward to Hadley before taking this southeastward course. In this loop it has much gravelly drift, but elsewhere is composed chicfly of clayey though rather stony till. The onter member and the united moraine is largely of stony character with a few gravel knolls and a stony loam soil. There is a narrow strip of outwash gravel on part of the outer border. There was also a strong glacial drainage down Chanarambie Creek from Chandler.

Outside the moraine just outlined a thin veneer of young Wisconsin drift is spread over the eroded surface of the old gray drift. It only partly fills the interglacial valleys cut in that drift. The soil in this area is a wind drifted silt loam, coating the till to a depth of only a few inches. The subsoil is a pebbly clay loam with fewer stones than on the moraine.

East of the moraine that forms the crest of the Cotean is a broad till plain covering more than half of the county, and having a rich black clay loam soil. Northeast of this plain is a strong morainic system coming in from the northwest and sweeping around the south and east side of 
Lake Shetek. It then follows the east side of Des Moines River southeastward into Cottonwood County. It is separable into several ridges in the east part of the county. The general elevation of this moraine is about 300 feet lower than the crest of the Coteau, being between I,500 and 1,600 feet above sea level. The moraine contains much stony drift all along its course in this county with occasional gravelly knolls. There was a weak outwash from the moraine into the Des Moines valley.

Another till plain several miles in width crosses the northeast part of the county. This has a rich black clay loam soil. Northeast of it, in the extreme northeast corner of the county, is another morainic system composed of several narrow ridges separated by swales or narrow plains. This moraine is less stony than the others and has a pebbly clay loam soil, while the soil in the swales is a black clay loam.

\section{Percentages of Classes of Land in Murray County}

\begin{tabular}{|c|c|c|}
\hline & Square miles & Per cent \\
\hline 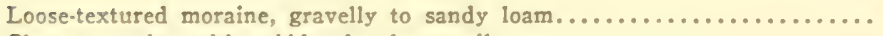 & 125 & 17.75 \\
\hline 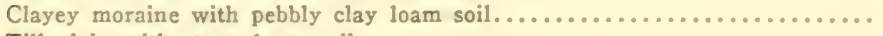 & 60 & 8.52 \\
\hline 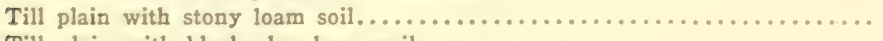 & 30 & 4.26 \\
\hline 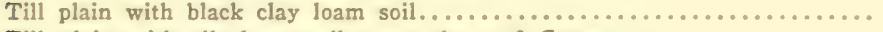 & 410 & 58.24 \\
\hline 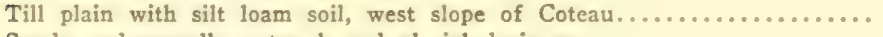 & 44 & 6.25 \\
\hline 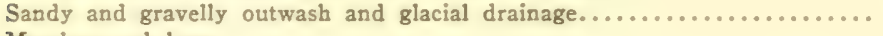 & 20 & 2.84 \\
\hline 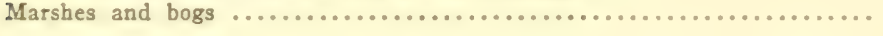 & 15 & 2.13 \\
\hline & 704 & 99.99 \\
\hline
\end{tabular}

Farm and Crop Data for Murray County from Census of IgIo

Rural population 8,74 I or 12.4 per square mile

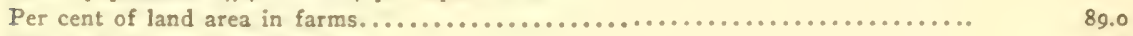

Per cent of farm land improved.................................... 88.7

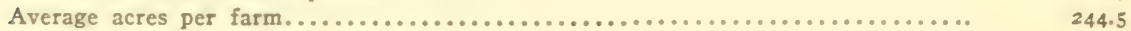

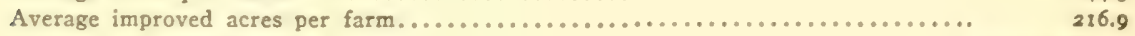

Value of all farm property.................................... $\$ 23,455,837$

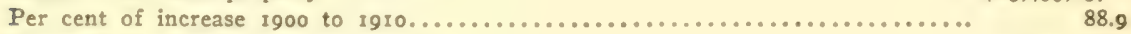

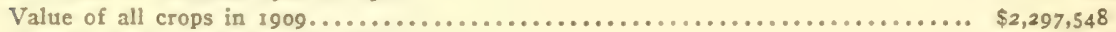

Cereals (oats, corn, barley, wheat, rye)........................... \$1,760,449

Other grains and seeds........................................\$147,930

Hay and forage . . . . . . . . . . . . . . . . . . . . . . . . . . . . . . . $\$ 309,552$

Vegetables ............................................... \$ $\$ 69,949$

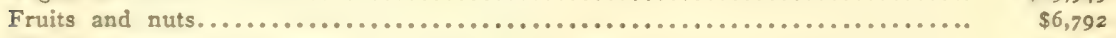

All other crops............................................. $\$ 2,876$

- Tame grass, 44,654 tons; wild grass, 33.318 tons.

\section{COTTONWOOD COUNTY}

Cottonwood County is located in southwestern Minnesota with Windom as the county seat. About 200 square miles in the southwest part of the county is drained southward by Des Moines River. The remainder of the county is drained northeastward to the Minnesota River.

A quartzite ridge standing between 1,200 and 1,400 feet above sea level crosses its northeast part, and has numerous small exposures of bare rock. Elsewhere the county is heavily covered with glacial deposits. 
There are several moraines crossing the county from northwest to southeast. Narrow strips of gravelly and sandy outwash follow the outer border of moraines in the southwest part of the county, while the line of glacial drainage follows down the Des Moines valley across Jackson County into Iowa. The moraines include occasional clusters of sharp gravelly knolls, but they are mainly of clayey till with a rich pebbly clay loam soil. In the north part of the county, in T. I08, R. 37 TV., there is a conspicuous belt of gravelly knolls running from Section s, to Section I 3 , a distance of about + miles. The trend of this gravelly belt is jarallel with the neighboring moraines both north and south of it, hut it does not connect with a definite moraine, there being a till plain all around it.

The till plains, which occupy more than half the surface of the county, have a rich soil of dark color with a pebbly clay loam subsoil.

\section{Percenteges of Classes of Land in Cottonwood County}

Square miles Percent

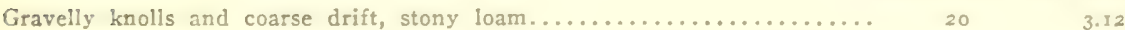

Clayey moraine with pebbly clay loam soil.................... I $45 \quad 22.65$

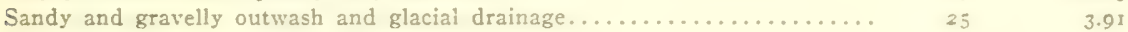

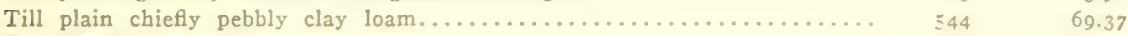

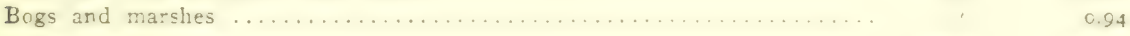

$\overline{640} \quad \overline{99.99}$

Farm and Crop Data for Cottonwood Connty from Census of 1010

Rural population 8,880 or 14 per square mile

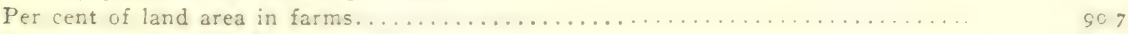

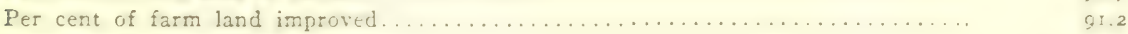

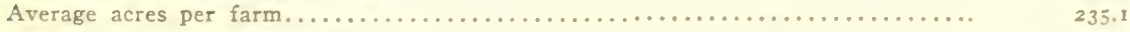

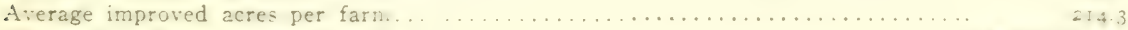

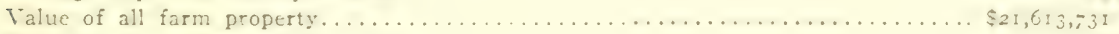

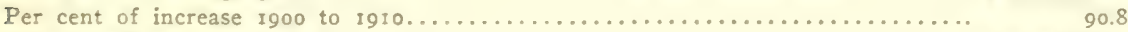

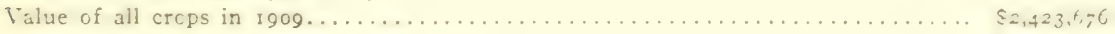

Cereals (oats, corn, barley, wheat, rye)...................... $\$ 1,960,152$

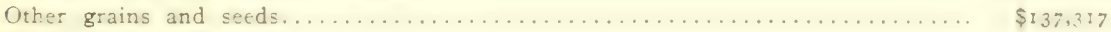

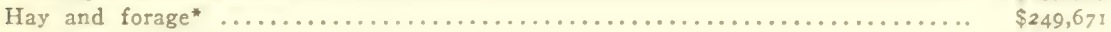

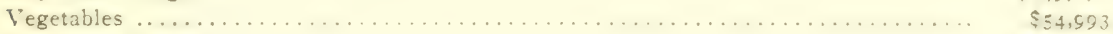

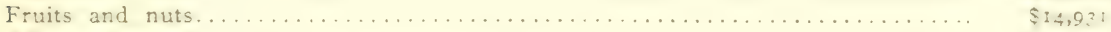

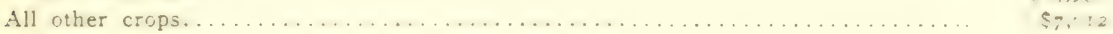

- Tame grass, 31,625 tons; wild grass, 43,956 tons.

\section{WATONWAN COUNTY}

Watonwan County is situated in the southern part of the state. with St. James as the county seat. The county is drained to the Minnesota River, almost entirely by Watonwan River and its tributaries. The altitude is nearly all between $I, 000$ and $I, 200$ feet, but the southwest corner reaches about I.300 feet, and part of Watonwan valley is below I,,$\infty$ feet.

Several weak moraines cross the county from northwest to southeast. They are rather diffuse knolly strips with flat areas anong the knolls. They are composed largely of clayey till but there are orational sravelly knolls. 
The greater part of the county is a till plain with a rich black clay loam soil. There is, however, an area of about 30 square miles immediately northeast of St. James in which the soil is sandy.

Border drainage channels, lying just outside a moraine in the northwest part of the county have sandy and somewhat marshy surface. They are not so well developed in the south part of the county. There may have been a ponding of water there along the border of the ice. Such ponding is suggested by the presence of a general coating of silt a few inches in depth over the pebbly till immediately outside the moraines. The marsh lands of the county are chiefly along the lines of border drainage.

\section{Percentages of Classes of Land in Watonwan County}

Square miles Per cent

\begin{tabular}{|c|c|}
\hline Gravelly knolls and stony parts of moraines, stony loam & Io \\
\hline 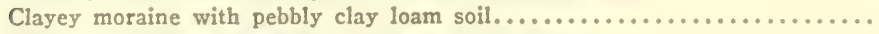 & 90 \\
\hline 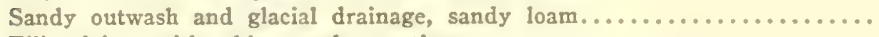 & 20 \\
\hline 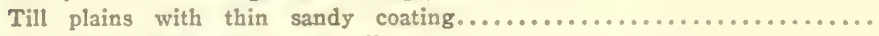 & 30 \\
\hline 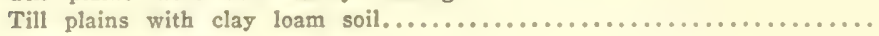 & 270 \\
\hline 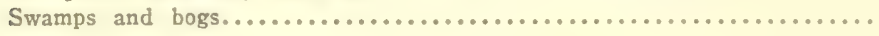 & 84 \\
\hline
\end{tabular}

Farm and Crop Data for Watonwan County from Census of 1910

Rural population 7,135 or $\$ 6.4$ per square mile

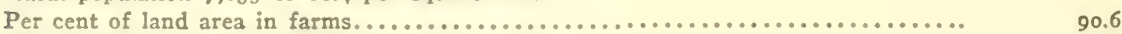

Per cent of farm land improved................................... 89.7

Average acres per farm.......................................... 198.3

Average improved acres per farm................................ 178.0

Value of all farm property......................................... \$16,300,220

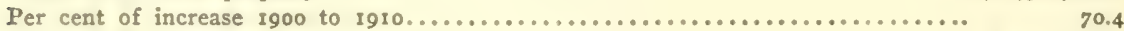

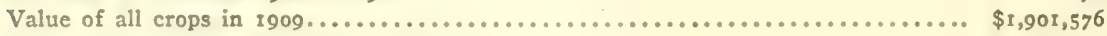

Cereals (oats, corn, wheat, barley, rye)........................... $\$ 1,528,960$

Other grains and seeds..................................... \$32,144

Hay and forage .......................................... \$272,911

Vegetables ................................................... \$41,909

Fruits and nuts.............................................. \$1 3,197

All other crops.......................................... \$12,375

- Tame grass, 30,397 tons; wild grass, 38,534 tons.

\section{BLUE EARTH COUNTY}

Blue Earth County is located in the southern part of the state south of the big bend of Minnesota River, and Mankato is the county seat. The drainage is all northward into the Minnesota, and the lower courses of several streams which converge toward the Minnesota at Mankato have deep valleys which have been utilized by certain railway lines in rising from the Minnesota valley to the upland plain. The greater part of the county is a plain standing between $I, 000$ and $I, I 00$ feet above sea level. The immediate bluffs of the Minnesota are 975 to I,000 feet, but the river is only 756 feet at Mankato. 
In the northwest part of the county along and north of the Watonwan River there is a morainic belt with two more or less distinct ridges or members. Its soil is classed as Marshall loam and Marshall fine sandy loam in the report on that county by the U. S. Bureau of Soils. ${ }^{3}$ Associated with this moraine are sandy deposits that have been distributed in part by the wind from the glacial outwash. The outwash seems to have been sand. There was probably more or less ponding of the waters in the vicinity of the great bend of the Minnesota at the time the moraine was forming, as the Minnesota valley below there had not yet been deeply excavated.

The greater part of the county is a plain with a clay loam to silt loam soil, classed by the Bureau of Soils as Marshall clay loam and Marshall silt loam. The clay loam is in parts of the county where the till is practically at the surface. The silt loam is where it has a thin coating of nearly pebbleless silt. Very flat parts of the till plain, whether covered with silt or not, usually have a black soil, and this is classed as Fargo clay or Fargo clay loam. The silt which covers the till is seldom more than 2 or 3 feet in thickness, and seems to have been laid down, as already noted, in the ponded waters which occupied the plain for a brief time during the opening of the Minnesota valley. These waters appear to have found outlet for a short time northeastward past Elysian to Cannon River. The duration of the ponded condition was so brief, however, that no definite shore lines appear to have been developed.

There are sharp gravel knolls in the south part of the county in two small groups. One group is 2 to 3 miles northeast of Amboy, and another about 5 miles west of that village. These knolls rise 50 to 75 feet above the level of the bordering plain and exceed I,IOO feet above sea level. In the extreme northeast corner of the county are also gravelly hills which rise above $I$, IOo feet.

Area of Different Soils in Blue Earth County (from Report of Bureau of Soils, 1906)

\begin{tabular}{|c|c|c|}
\hline & Acres & Per cent \\
\hline larshall clay loam (pebbly clayey till plain). & 185,152 & 38.7 \\
\hline farshall silt loam (till with thin silt cover) $\ldots \ldots \ldots \ldots \ldots \ldots$ & 128,704 & 26.9 \\
\hline 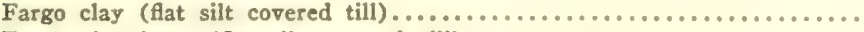 & 27,968 & 5.8 \\
\hline 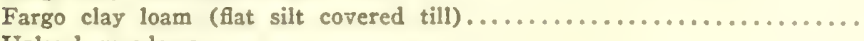 & 23,936 & 5.0 \\
\hline 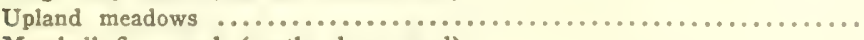 & 19,264 & 4.0 \\
\hline 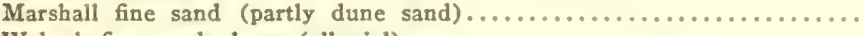 & 15,872 & 3.3 \\
\hline 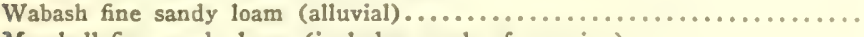 & 14,528 & 3.0 \\
\hline Marshall fine sandy loam (includes much of moraine).................. & 13,824 & 2.9 \\
\hline 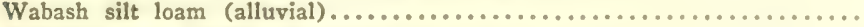 & 13,312 & 2.8 \\
\hline 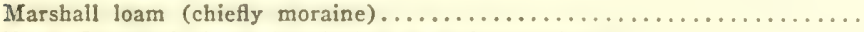 & 8,768 & \.8 \\
\hline reas in moraines) $\ldots . . . \ldots \ldots \ldots . . . .$. & 7,680 & 1.6 \\
\hline Peat ... & 7,680 & 1.6 \\
\hline Mankato s & 4,032 & 0.9 \\
\hline
\end{tabular}




\section{Area of Different Soils in Blue Earth County (Continued)}

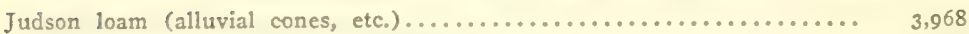

Mankato sandy loam (on rock ledges) ............................ 2,816

Mankato loam (on rock ledges) ........................... $\quad$, 600

479,104

Farm and Crop Data for Blue Earth County from Census of 1910

Rural population 15,076 or 20 per square mile

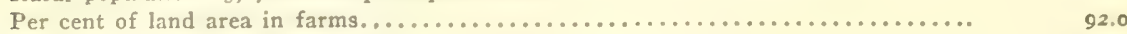

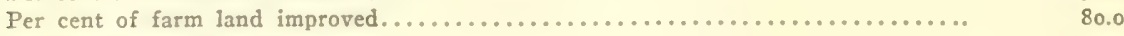

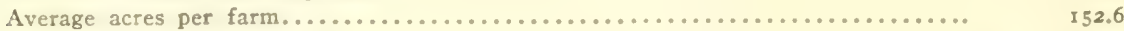

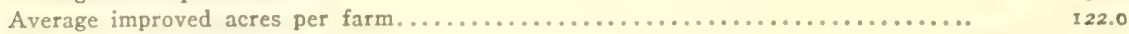

Value of all farm property..................................... \$32,619,319

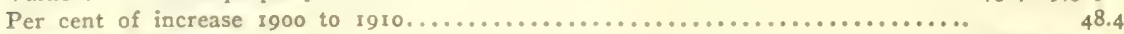

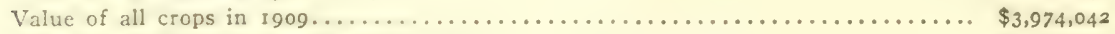

Cereals (wheat, corn, oats, barley, rye).......................... \$3,225,658

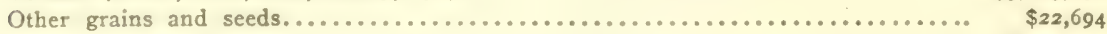

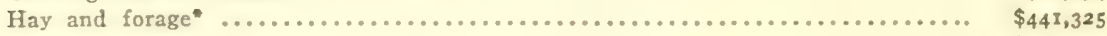

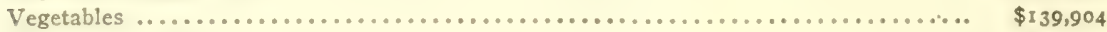

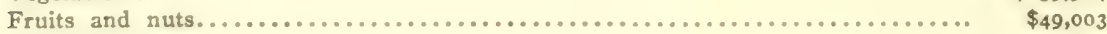

All other crops............................................ \$95,458

- Tame grass, 58,960 tons; wild grass, 55,309 tons.

\section{WASECA COUNTY}

Waseca County is located in the southern part of the state, with Waseca as the county seat. Nearly all the county is drained westward by Le Sueur River to the Minnesota; but a few square miles on the north edge are tributary to Cannon River which drains eastward to the Mississippi.

A strong moraine runs from north to south through the eastern part of the county, but the remainder is a till plain. The moraine contains occasional gravel knolls but is mainly a clayey till. The till plain has a black clay loam soil with pebbly clay loam subsoil. The lower part of this plain has a coating of silt that seems referable to ponded glacial waters. These appear to have found outlet northeastward past Elysian to Cannon River. There is a well defined channel connecting Lake Elysian with the Cannon River drainage in southern Le Sueur County. The present outlet of Lake Elysian is in the opposite direction and leads to Le Sueur River and the Minnesota.

\section{Percentages of Classes of Land in Waseca County}

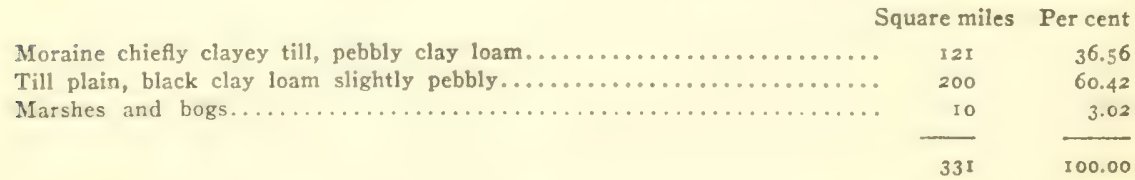

Farm and Crop Data for Waseca County from Census of Igro

Rural population 8,554 or 20 per square mile

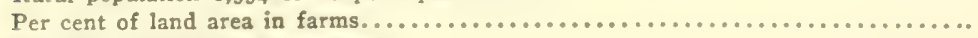

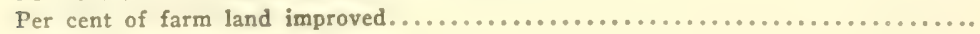

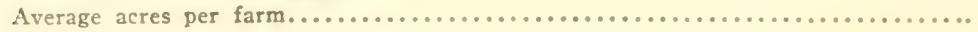


Farm and Crop Data for Waseca County (Continued)

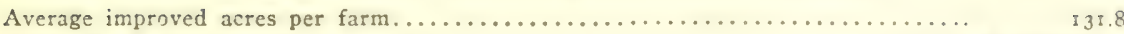

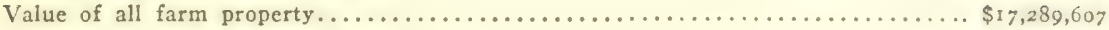

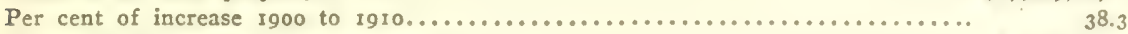

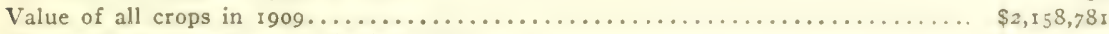

Cereals (wheat, corn, oats, barley, rye)....................... \$1,734,609

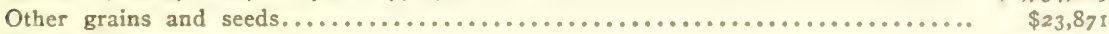

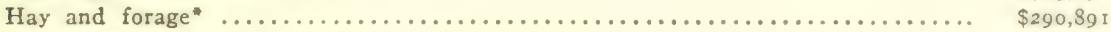

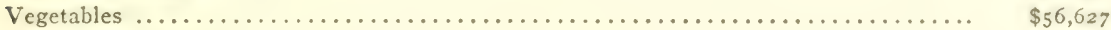

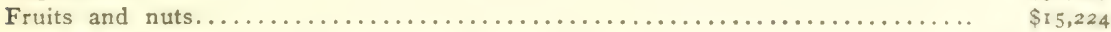

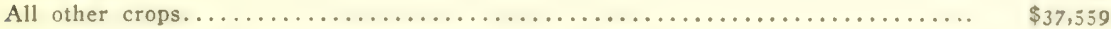

* Tame grass, 26,340 tons; wild grass, 53,617 tons.

\section{STEELE COUNTY}

Steele County is located in southern Minnesota with Owatonna as the county seat. The drainage is nearly all northward through Straight River to Cannon River and thence to the Mississippi. A few square miles on the western edge drain westward to the Minnesota River. A few square miles on the eastern edge drain eastward by branches of the Zumbro to the Mississippi. The extreme southeast part drains to the Cedar River and thence southward through Iowa to the Mississippi.

The county is traversed by moraines trending north to south which were formed on the eastern side of the Keewatin ice field. There are small outwash gravel plains along the eastern or outer border of each moraine. There are also narrow strips of till plain between the moraines. Marshes of considerable extent occur on outwash plains in the southern part of the county, and on till plains in the northern part. Their original extent has, however, been somewhat reduced by ditching.

The moraines are composed largely of clayey till, but a prominent moraine in the southeast part of the county contains considerable gravel. The outwash and glacial drainage deposits are generally a rather light sandy gravel. The till plains have a rich black clay loam soil with pebbly clay loam subsoil.

\section{Percentages of Classes of Land in Steele County}

Square miles Per cent

Gravelly and stony moraine, stony loam..................... $12 \quad 2.78$

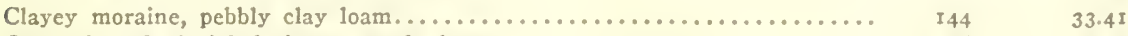

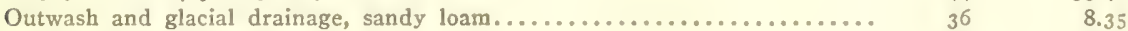

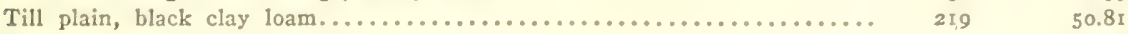

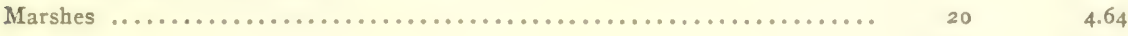

$431 \quad 99.99$

Farm and Crop Data for Stecle County from Census of 1910

Rural population 9,373 or 21.7 per square mile

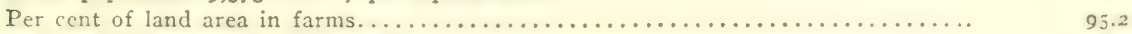

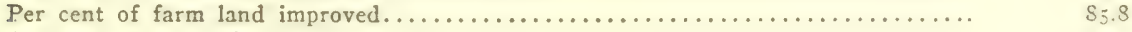

Average acres per farm....................................... 143.9

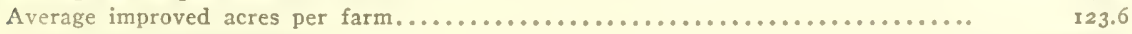

Value of all farm property..................................\$19,032,988

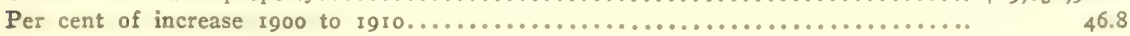


Farm and Crop Data for Steele County (Continued)

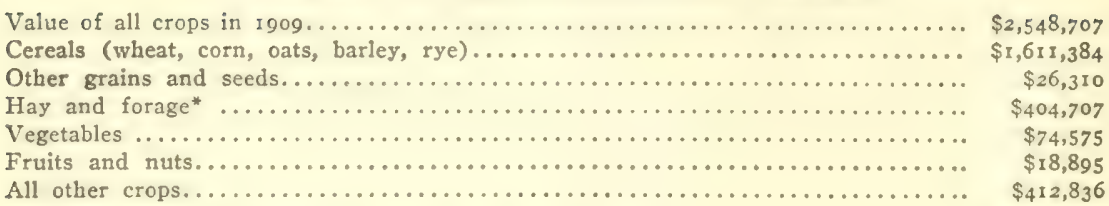

- Tame grass, 37,286 tons; wild grass, 48,647 tons.

\section{DODGE COUNTY}

Dodge County is situated in the southeast part of the state with Mantorville as the county seat. The drainage of nearly all of the county is eastward by branches of Root and Zumbro rivers to the Mississippi, but the southwest part is drained southward by Cedar River through Iowa.

The eastern edge of the young Wisconsin drift lies near the west border of the county. It is marked by a chain of low knolls and very thin deposits of young till. The knolls are in some cases gravelly, but clayey till prevails.

The pre-Wisconsin or old gray drift was originally a till plain, and in the western part of the county the plain is still well preserved, but in the eastern part it has become greatly eroded, and the surface now is occupied by broad, shallow valleys with gentle slopes. There are a few gravelly knolls, but chiefly in the southeast part. Gravel is also found along the Cedar valley in the southwest part, but there the surface is nearly plane.

Small areas in the northeast part of the county are covered with loess to a depth of several feet. The loess is in spur-like extensions westward from the main loess area in Olmsted County.

In the beds of the shallow valleys, bowlders are in places very numerous, as if concentrated by erosion. They are rare on divides, or on the remnants of the original plain.

The soil on the flat divides and level parts of the upland plain is generally a heavy black clay loam, while on the slopes it is looser textured with a larger admixture of pebbly material.

\section{Percentages of Classes of Land in Dodge County}

\begin{tabular}{|c|c|c|}
\hline & Square miles & Per cent \\
\hline 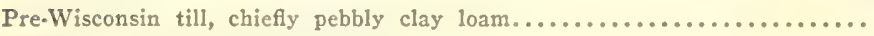 & 350 & 79.54 \\
\hline 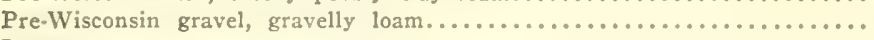 & 8 & 1.82 \\
\hline 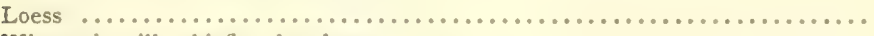 & 33 & 7.50 \\
\hline 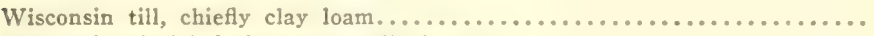 & 32 & 7.27 \\
\hline 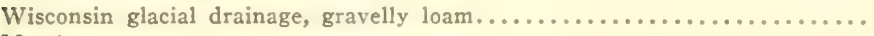 & 12 & 2.73 \\
\hline 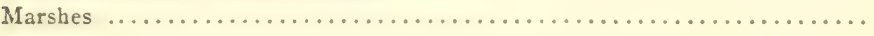 & 5 & 1.13 \\
\hline & 440 & 99.99 \\
\hline
\end{tabular}


Farn and Crop Data for Dodge County from Census of 1910

Rural population 8,350 or 19 per square mile

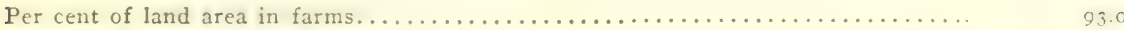

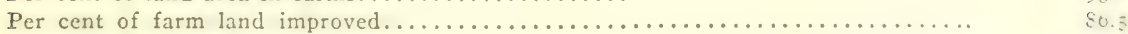

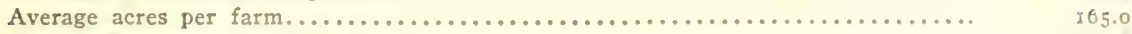

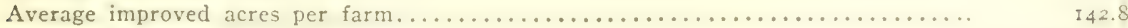

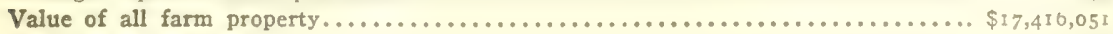

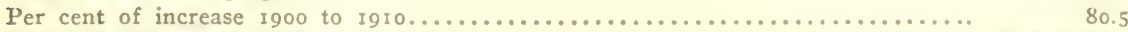

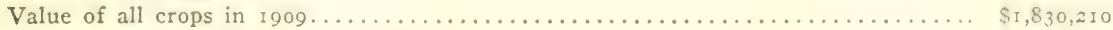

Cereals (barley, oats, corn, wheat, rye)...................... \$1,175,703

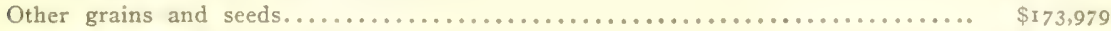

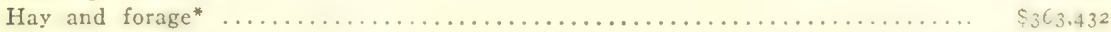

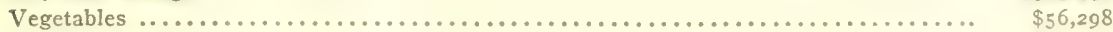

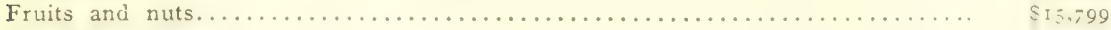

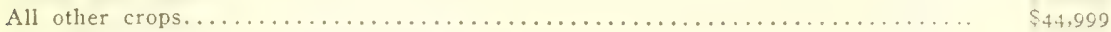

* Tame grass, 62,826 tons; wild grass, 8,079 tons.

\section{OLMSTED COUNTY}

Olmsted County, of which Rochester is the county seat, is located in the southeast part of the state. The drainage of the eastern part of the county is eastward by Whitewater River; of the central and northwest parts northeastward by the Zumbro River; and of the southern part eastward by Root River to the Mississippi. The divides separating these three river systems rise in places slightly above 1,300 feet, and the greater part of the county is between I,200 and I,300 feet. The valleys are cut to a much lower level, and the Zumbro River falls below 900 feet at the north edge of the county. The principal streams are bordered by prominent rock bluffs, but the uplands are gently undulating. The cover of drift is generally thin. There are many sink holes in the limestone in the southern part of the county.

The drift is all of pre-Wisconsin age and has suffered considerable leaching and weathering. It is generally a stiff clayey till which becomes calcareous below the leached part at a depth of 4 to 6 feet.

Large gravel knolls occur in the line of an old valley in southern Oronoko Township, and there are smaller ones here and there in the central and western part of the county, and very rarely in the eastern part. Most of the drift in the valleys and lowlands is loose-textured, both in the low bottoms and on terraces.

Loess deposits form a coating widely over the till in the northeast quarter of the county and in several of the southern townships, but in the remainder of the county it is in isolated strips. A belt of land several miles wide running eastward from Rochester into Winona County is free from loess, - the land both to the north and south of it being widely loess covered. 


\section{Percentages of Classes of Land in Olmsted County}

\begin{tabular}{|c|c|c|}
\hline & Square miles & Per cent \\
\hline 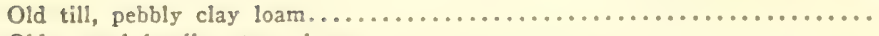 & 250 & 37.54 \\
\hline 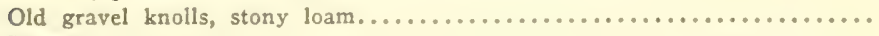 & 20 & 3.00 \\
\hline 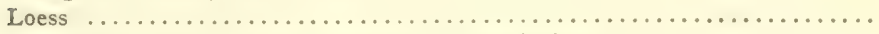 & 320 & 48.05 \\
\hline 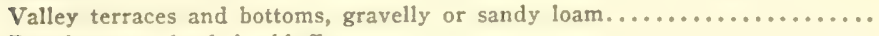 & 60 & 9.01 \\
\hline 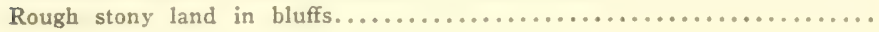 & 16 & 2.40 \\
\hline & 666 & 0 \\
\hline
\end{tabular}

Farm and Crop Data for Olmsted County from Census of I9IO

Rural population 12,38 I or 19 per square mile

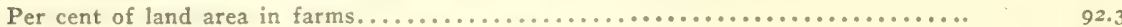

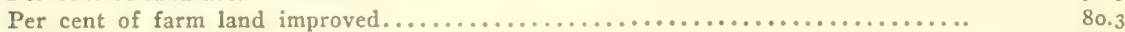

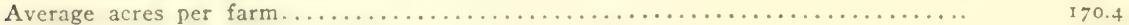

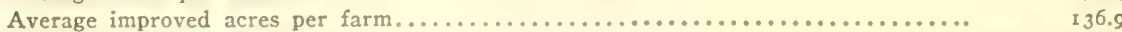

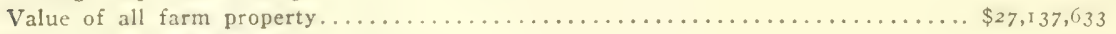

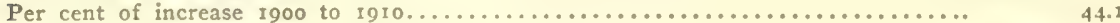

Value of all crops in $1909 . \ldots \ldots \ldots \ldots \ldots \ldots \ldots \ldots \ldots \ldots \ldots \ldots \ldots \ldots \ldots \ldots \ldots \ldots \ldots \ldots \ldots 2,9 . \ldots 4,191$

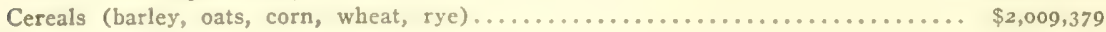

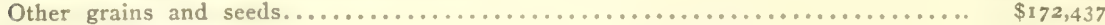

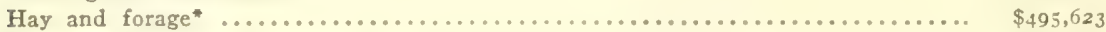

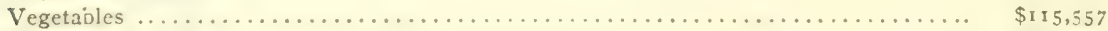

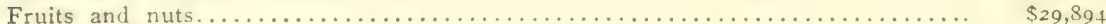

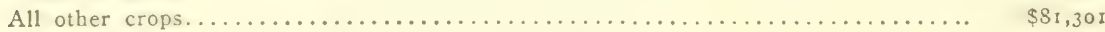

- Tame grass, 77,591 tons; wild grass, 5,478 tons.

\section{WABASHA COUNTY}

Wabasha County, with Wabasha as the county seat, borders the Mississippi in southeastern Minnesota. The drainage is all to the Mississippi and chiefly through Zumbro River. The highest altitude of the uplands is remarkably uniform, the dividing ridges being between I, IOO and I,200 feet above sea level over nearly all the county. The immediate bluffs of the Mississippi are generally over r, Ioo feet, or fully 450 feet above the stream, which is 664 feet above sea level at Lake Pepin and about 650 feet where it leaves the county.

Over much of the uplands there is a mere trace of drift with scattered pebbles and bowlders, but in places it reaches 40 feet or more. Leaching ordinarily extends to a depth of at least 6 feet, below which the till is somewhat calcareous.

There are knolls and drift ridges on the uplands in the northwest corner of the county a few miles southwest of Lake City. These are partly of gravel but contain much till. The highest ones rise 50 to 75 feet above the bordering plains, but the usual height is 20 to 30 feet. They may mark an old ice border, the ice being on the southwest side of the belt, but it is not traceable for more than Io miles.

The uplands of Wabasha County are covered with loess and it extends down on the slopes of the main valleys nearly to the streams where these slopes are gentle, but in many cases the valleys have precipitous rock bluffs. 
The valley bottoms, even of the small tributaries of the Mississippi, are broad and have a rich soil. The small tributaries carry a slack water filling of silt formed during the filling up or aggradation of the Mississippi by glacial drainage deposits, which reached a height of more than Ioo feet above the present Mississippi, or to 775 to 800 feet above sea level. The filling along the Mississippi is a sandy gravel with only a slight cover of silt or loam. There is a similar filling along the Zumbro and its several branches. It is now preserved in narrow terraces along the valley borders of the Mississippi.

The early settlements were on the gravel terraces along the rivers, but soon were extended into the interior as the forests were largely oak openings easily cleared, and the southwest part of the county was prairie. The river transportation, which was the sole line in pioneer days, and later supplanted to some extent by railway lines, is still of considerable importance.

\section{Percentages of Classes of Land in Wabasha County}

Square miles Per cent

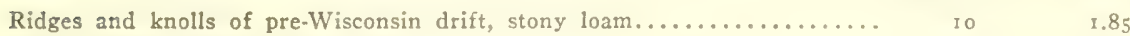

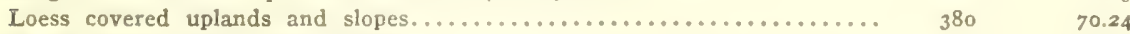

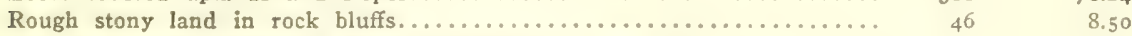

Bottom land and terraces of small tributaries, silt loam soil.......... $\quad$ i5 $\quad 2.77$

Gravel and sand deposits of Mississippi and Zumbro valleys, sandy to

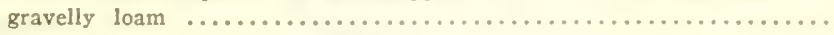

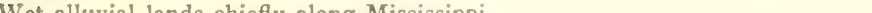

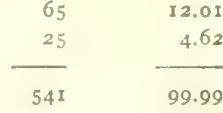

Farm and Crop Data for Wabasha County from Census of 1910

Rural population 9,448 or 17.5 per square mile

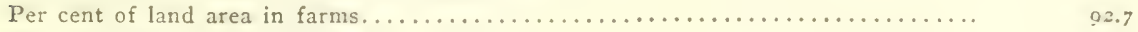

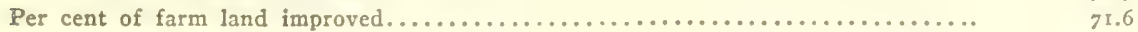

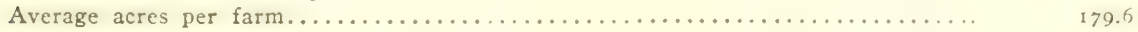

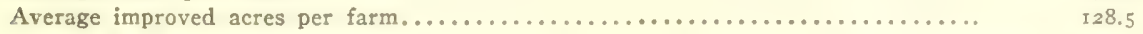

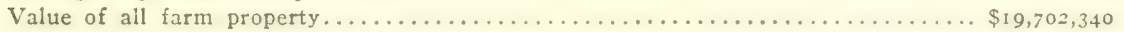

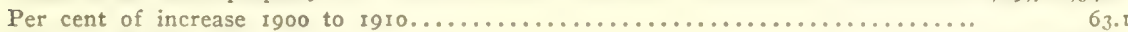

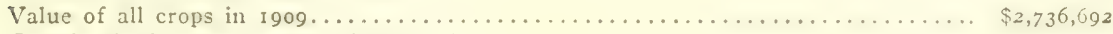

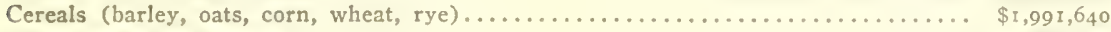

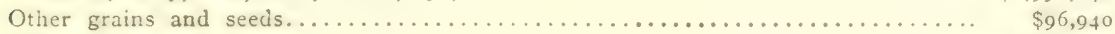

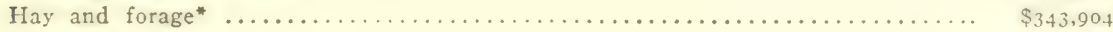

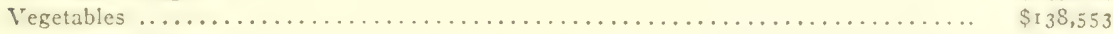

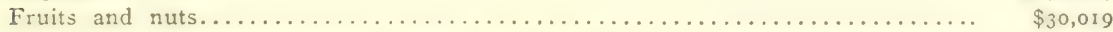

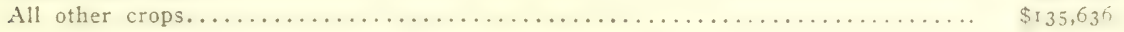

- Tame grass, 53,890 tons; wild grass, 5,052 tons.

WINONA COUNTY

Winona County, of which Winona is the county seat, borders the Mississippi River in southeastern Minnesota. The entire county is drained northeastward or eastward into the Mississippi, much of it by short tributaries heading within the county. The uplands stand $I, 200$ to 
I,300 feet above sea level, the immediate bluffs of the Mississippi being generally above $I, 200$ feet.

There is very little glacial material in the county, yet the presence of foreign pebbles and occasional bowlders on the uplands indicates that glaciation once extended over nearly all the county, there being only a few square miles in the southeast part in which drift pebbles have not been noted.

The uplands are covered by loess, except a narrow strip that extends from St. Charles eastward past Utica and thence southeast to Fremont. The part between Utica and Fremont has a light sandy soil from the breaking down of the sandstone formation which underlies it. To the west of Utica the soil is more clayey, being derived to some extent from the disintegration of limestone. In the loess-covered portion there is generally a reddish brown residuary clay between the rock and the loess. The glacial pebbles and bowlders are often imbedded in this residuary clay, which was evidently disturbed to some extent by the overriding ice.

The valleys are often bordered by precipitous rock bluffs, but even the small tributaries have wide bottom lands with a fertile soil. The Mississippi valley had been filled by sand and gravel to a level more than Ioo feet above the present stream, and the tributaries were graded to a corresponding height. The glacial river which flowed from the outlet of Lake Agassiz removed much of the filling from the Mississippi valley, but in the tributaries it is still present in large amount.

At the time of settlement, the greater part of the county had a somewhat open forest which was easily cleared, and the southwest part was prairie. Farms were therefore rapidly developed on the uplands as well as in the Mississippi bottoms.

\section{Percentages of Classes of Land in Winona County}

Square miles Per cent

Upland without loess, soil with underlying rock................. $27 \quad 4.24$

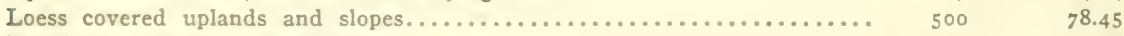

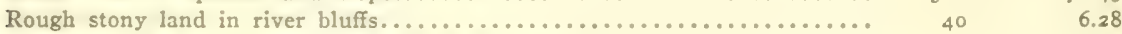

Gravel and sand deposits of the Mississippi valley................. $20 \quad 3.14$

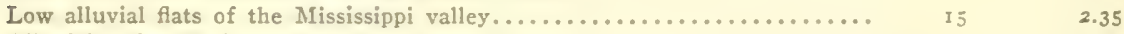

Alluvial and colluvial material in tributary valleys................. $35 \quad 5.49$

$637 \quad \overline{99.99}$

Farm and Crop Date for Winona County from Census of 1910

Rural population 12,070 or I9 per square mile

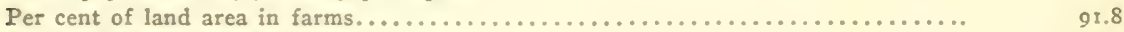

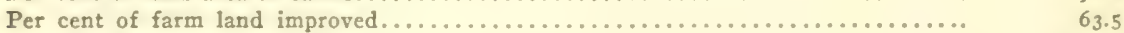

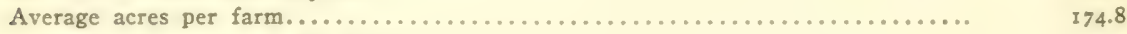

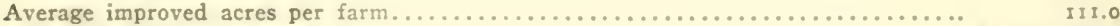

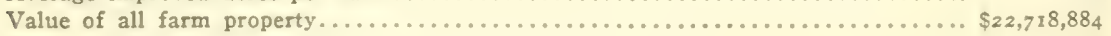

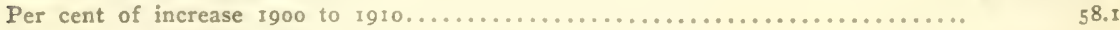

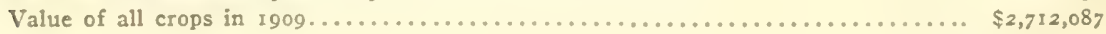


Farm and Crop Data for Winona County (Continued)

Cereals (barley, oats, corn, wheat, rye).......................... \$1,905,936

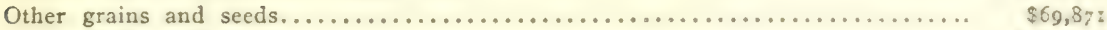

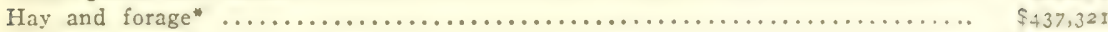

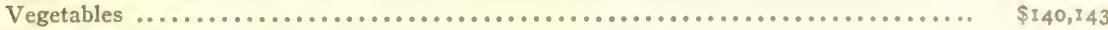

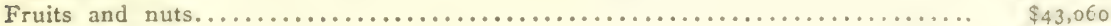

All other crops.............................................. \$115,756

- Tame grass, 70,052 tons; wild grass, 1,473 tons.

\section{HOUSTON COUNTY}

Houston County is the southwest corner county of Minnesota, with Caledonia as the county seat. The drainage is eastward into the Mississippi, more than half of it being through Root River. The southern edge of the county drains to Upper Iowa River. Much of the upland stands between I,IOO and I,200 feet above sea level, and maintains a height of $\mathrm{I}, \mathrm{IOO}$ feet to the brow of the Mississippi bluff. A ridge southwest of Caledonia rises slightly above $I, 300$ feet. The erosion is broad along many of the valleys, and bottom lands are extensive. The breaking down of the upland is so great that it is preserved only in narrow strips between drainage lines. There are broad rock shelves at various levels on the slopes.

The western part of the county bears evidence of glaciation in the occurrence of bowlders and small pebbles of foreign rocks; but there is little or no till preserved, and the topography is essentially the same as in the driftless area.

Loess covers the uplands except on a few sharp ridges and knobs,the high ridge southwest of Caledonia being nearly free from it. It is present on gentle slopes, and on the rock shelves bordering the valleys. It rests on a very gummy residuary clay, formed from the decomposition of the limestone, but is itself porous and highly productive.

The Mississippi valley had been filled to a height of about Ioo feet above the present stream by sand and gravel, but at the last or Wisconsin glacial stage this filling was removed largely by the glacial river from Lake Agassiz. Small tributary valleys silted up to correspond with the filling on the Mississippi. The alluvial deposits of Root River have a gentle down stream slope and are of fine sand.

Percentages of Classes of Land in Houston County

\begin{tabular}{|c|c|c|}
\hline & Square miles & Per cent \\
\hline 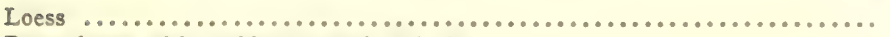 & 250 & 43.86 \\
\hline 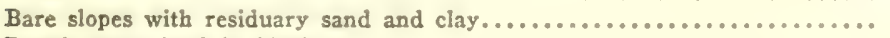 & 150 & 26.32 \\
\hline 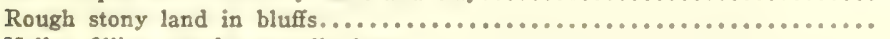 & 35 & 6.14 \\
\hline 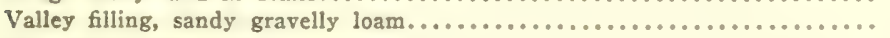 & 103 & $\$ 8.07$ \\
\hline 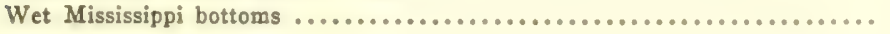 & 32 & 5.60 \\
\hline
\end{tabular}


Farm and Crop Data for Houston County from Census of Igro

Rural population 10,472 or 18.4 per square mile

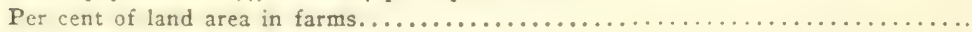

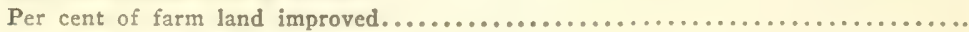

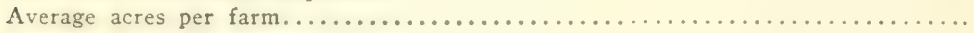

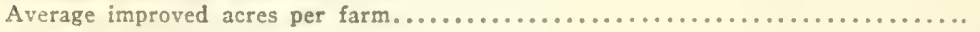

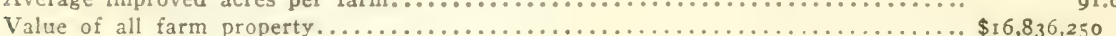

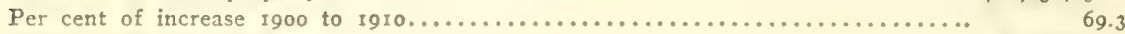

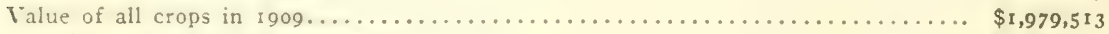

Cereals (corn, oats, barley, wheat, rye)....................... \$1,29r,525

Other grains and seeds...................................... \$27,905

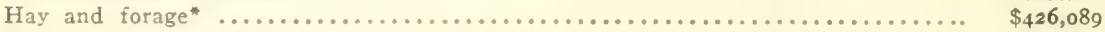

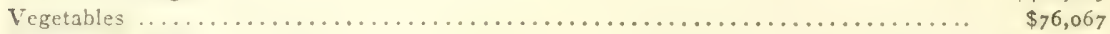

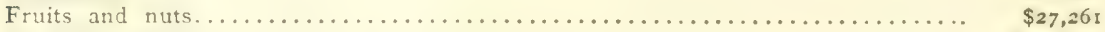

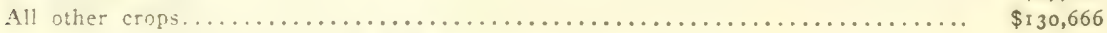

- Tame grass, 63,514 tons; wild grass, 2,303 tons.

\section{FILLMORE COUNTY}

Fillmore County is the second from the Mississippi on the southern border of the state, with Preston as its county seat. The drainage of nearly all the county is eastward through Root River to the Mississippi, but a few square miles on the southern edge drain southward to the upper Iowa River which enters the Mississippi just south of the state line. The valleys are shallow in the southwest part of the county with bluffs of glacial material; but elsewhere they are cut deeply into hard rock formations and usually have steep bluffs. There are broad rock shelves along the valley sides which greatly widen out the space between uplands on opposite sides of streams. Only narrow strips come up to the height of the upland plain. The remnants of this upland plain stand I, 300 to I, 375 feet above sea level in the western and southern part of the county, and but little below I,300 feet in the remainder. The valleys in the east part are very deep, and Root River falls to 712 feet at the east line of the county.

Although the entire county has been glaciated it is only along the western edge of the county that thick deposits of glacial drift occur, there being in the remainder of the county only scattered bowlders and pebbles and an occasional small and thin deposit of till or gravel. The remaining deposits in the southwest part of the county are sufficient to fill up preglacial valleys $\mathrm{I} 50$ to 200 feet deep and make a thin coating on the preglacial divides. This heavy drift contains a blue calcareous till, but its surface is leached of limestone to a depth of several feet, and the till is of yellow color for about $\mathrm{I} 5$ feet. It is generally compact and clayey but has a rich clay loam soil.

In places, beds of quartz pebbles, much older than the glacial deposits, cover the limestone and form a conspicuous element in the soil. They are abundant in the vicinity of Granger and of Ostrander, and northward along the western edge of the county on preglacial divides. 


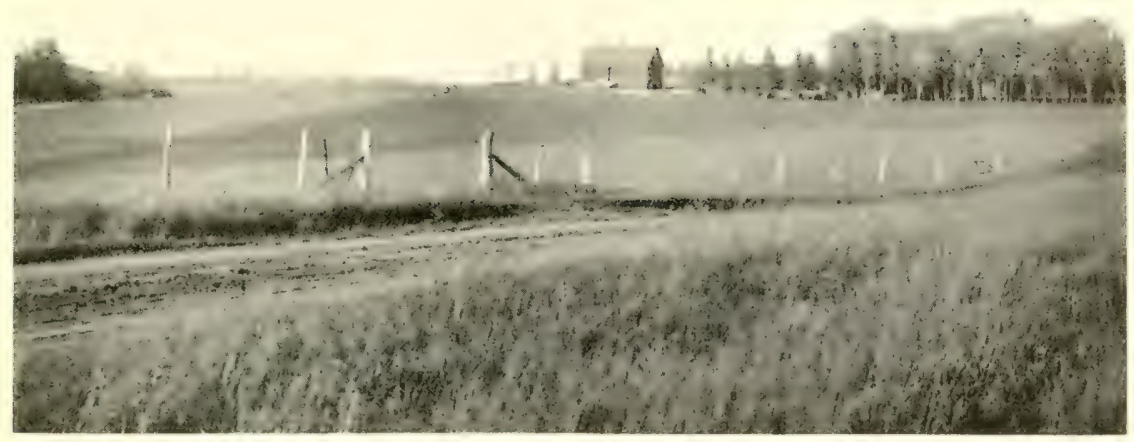

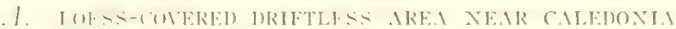

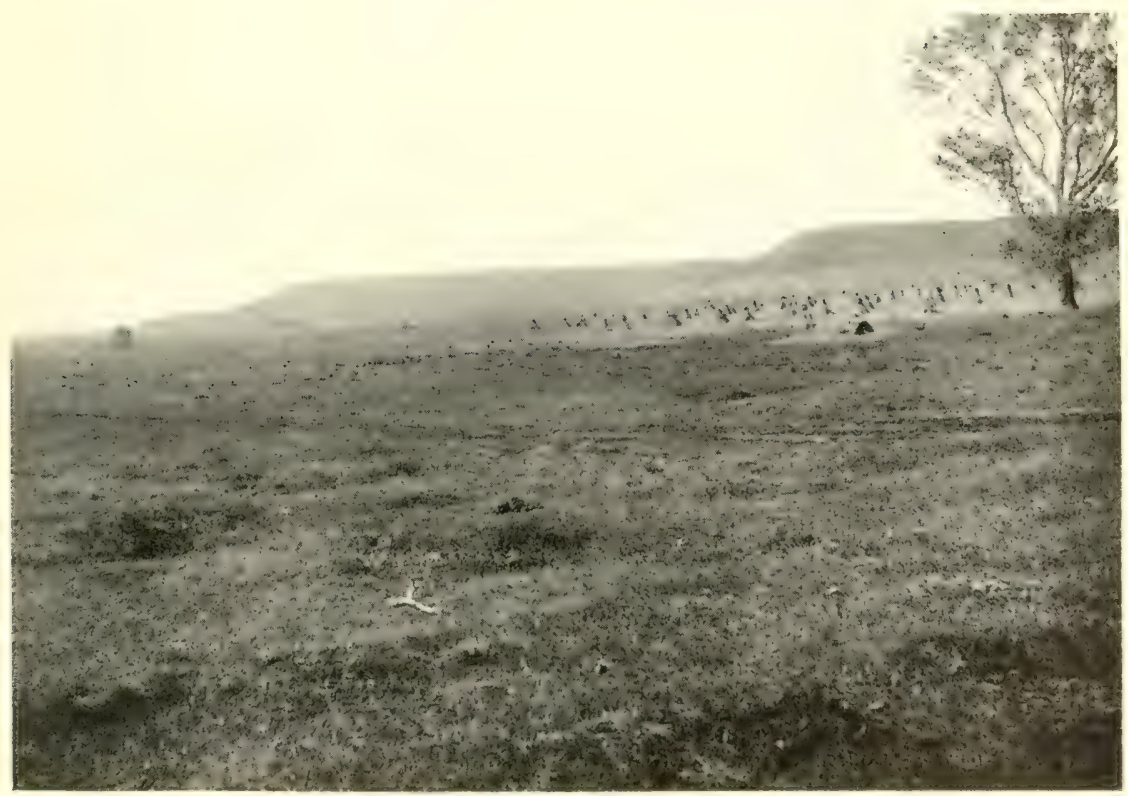

B. VALLEYS BORDERED BY IIMESTONE TABLELANDS NEAR HAMPTON 

The uplands are loess-covered, except in the western end of the county, and have a rich silt loam soil. The loess is usually Io to I 5 feet thick and is present on rock shelves and gentle valley slopes as well as on high uplands. Much of the area of thick drift in the sonthwest part of the country is free from loess, and so is part of the thin drift area to the east.

The valleys are much narrower in this county than in Houston, being nearer the heads of the preglacial drainage lines. Terraces of sand and gravel are present along them.

This county has been about as fully populated as at present for nearly fifty years, the population in 1870 being only 800 less than that of InIo. The rich loess soil with originally a light growth of oak forest has been easily converted into farm land. The water power along Root River was also early made use of for flour mills.

\section{Percentages of Classes of Land in Fillmore County}

Square miles Percent

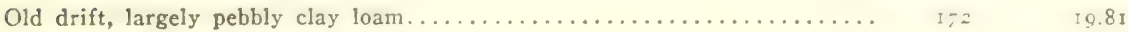

Loess covered uplands and slopes.......................... $480 \quad 55.30$

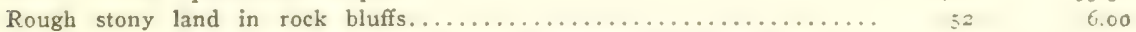

Bare slopes with residuary sand and clay and scattered drift pebbles...... I00 II.52

Valley bottoms with variable soil............................ $64 \quad 7.37$

$568 \quad \frac{1.37}{100.00}$

Farm and Crop Data for Fillmore County from Census of IQjo

Rural population 17,784 or 20.5 per square mile

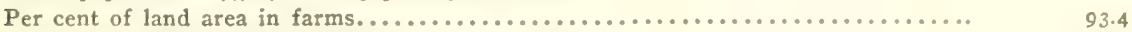

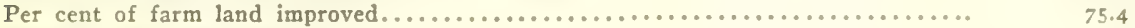

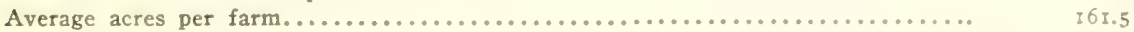

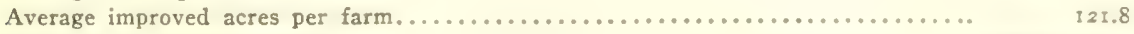

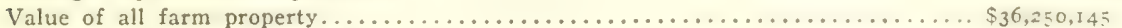

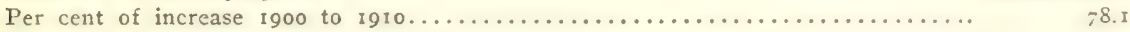

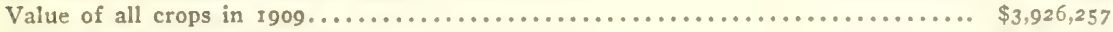

Cereals (oats, corn, barley, wheat, rye)........................ \$2,665,502

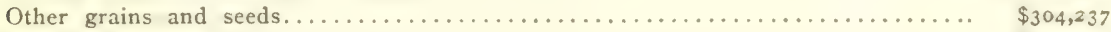

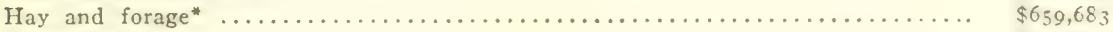

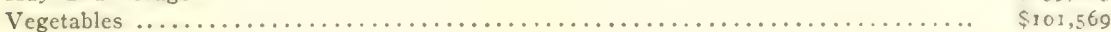

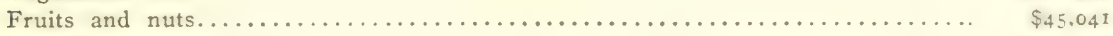

All other crops............................................. $\$ 150,25$

* Tame grass, 109,257 tons; wild grass, 3,389 tons.

\section{MOWER COUNTY}

Mower County, of which Austin is the county seat, is located on the southern border of the state, the third county from the Mississippi. The drainage of the west end of the county is southward by Cedar River into Iowa. The southeast part embraces the headwaters of upper Iowa River, whose course otherwise is in Iowa. The remainder of the county is drained eastward by Root River directly to the Mississippi. The divide between the Root River drainage and that of the Cedar and 
Upper Iowa rivers embraces the highest land in southeastern Minnesota, its altitude being I,350 to I,420 feet above sea level. The altitude declines westward to only I,200 to I,250 feet along the border of Cedar River. But eastward an altitude of more than $I, 300$ feet is maintained to the eastern limits of the county.

The drift deposits are thick along the high divide just mentioned, the rock surface there being only up to about $I, 300$ feet above sea level. In the southeastern part of the county the rock surface reaches fully I, 350 feet. It is about 1,200 feet in the western part of the county. In the eastern part, sink holes in limestone abound, but in most of the county the drift deposits are so thick that such direct underground drainage is blocked and even preglacial valleys are completely filled.

From Cedar River eastward the drift is pre-Wisconsin and chiefly a compact clayey till with pebbly clay loam soil. Its surface has been leached of limestone pebbles to a depth of 4 to 6 feet. This drift has in places strips of gravel along the streams, which in some cases appear to have been exposed by the removal of the overlying till, for wells show the gravel to extend back beneath the till on the slopes and uplands. In a few places quartz pebbles derived from preglacial gravel beds form a notable constituent of the drift. This is especially the case in the southern and eastern parts of the county.

The latest or Wisconsin drift has its eastern limits along the western side of the county. In places a weak moraine marks the limits, but along much of the border there is merely a thin deposit of this young drift. There was a weak outwash into Cedar valley forming sandy plains in the northwest part of the county. The Wisconsin drift is chiefly clayey till with pebbly clay loam soil.

\section{Percentages of Classes of Land in Mower County}

Square miles Per cent

Old or pre-Wisconsin till, chiefly pebbly clay loam.............. $595 \quad 83.68$

Old gravel chiefly along valleys, gravelly loam.................... $36 \quad 5.06$

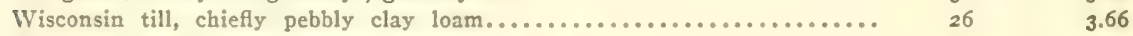

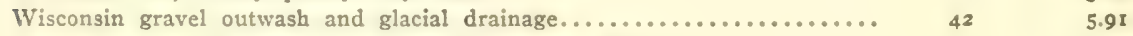

Rock, bare or with very scant cover, chiefly along valleys............ I2 $\quad$ I.69

Farm and Crop Data for Mower County from Census of Igro

Rural population 12,079 or 17 per square mile

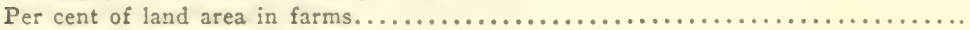

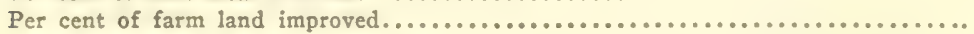

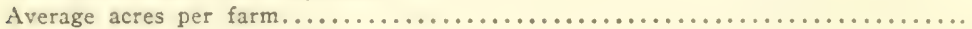

Average improved acres per farm.....................................

.

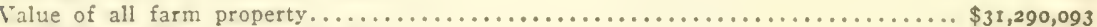

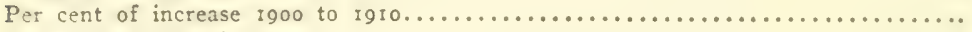

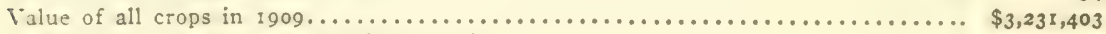

Cereals (oats, corn, barley, wheat, rye)........................ \$2,r46,0ro 
Farm and Crop Data for Mower County (Continued)

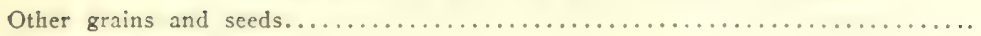

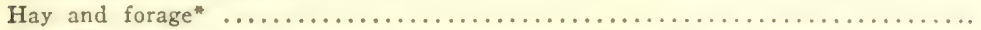

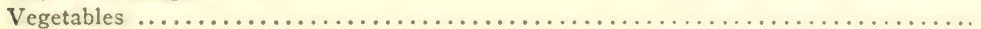

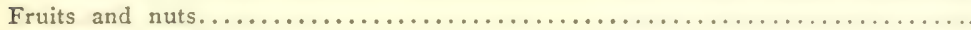

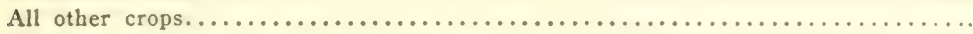

- Tame grass, 92,891 tons; wild grass, 9,582 tons.

$\$ 320,717$

$\$ 526,517$

\$I I 4,895

$\$ 18,442$

$\$ 104,822$

\section{FREEBORN COUNTY}

Freeborn County is on the southern border of the state, with Albert Lea as the county seat. It includes 20 townships or 720 square miles, with a land area of 700 square miles, the remaining 20 square miles being occupied by lakes. ${ }^{4}$ The greater part of the county is drained southeastward to Cedar River, but the northwest part drains northwestward to the Minnesota River. A few prominent points on moraines rise above I,300 feet, but the general altitude is between I,200 and I,300 feet above sea level.

This county was covered by the latest or Wisconsin glaciation, except a few square miles in the southeast corner township. The border there, however, is not strongly marked, and exposures of the drift are so shallow that it is in places difficult to determine the full limits of the Wisconsin drift. The southeast corner of the county has the broad swales and somewhat mature erosion topography of the pre-Wisconsin drift.

The Wisconsin drift is very thin for from 4 to 8 miles back from its limits. There a strong moraine appears whose trend is slightly west of south across the eastern part of the county. There are several subsequent moraines of considerable strength traversing the county in the same general course. The city of Albert Lea lies between two such moraines, while another moraine passes east of Alden and Hartland. Two weak moraines cross the northwest part of the county, passing on each side of Freeborn Lake.

There are extensive marshes in the eastern part of the county between the first and second strong moraine, one lying southeast of Geneva Lake, having an extent of at least 30 square miles. This seems to have been once an expansion of Geneva Lake, and its surface stands only a few feet above the present lake level. There are other marshes inclosed between moraines in the northern part of the county and in till plains in the northwest part.

The lakes at Albert Lea once had an altitude 45 feet higher than now, and were combined into a single large glacial lake that covered much of the present site of the city. The brickworks in the west part of the city use clay deposits laid down in this expanded lake. The lowering of the lake was due to the cutting down of its outlet along Shell Rock River. 
An extensive outwash plain of light sandy gravel lies immediately north and west of Albert Lea along the eastern border of a strong moraine. Another extensive outwash plain of sandy gravel connected with the same moraine, covers much of the southwest township of the county. There are also ontwash plains connected with preceding moraines extending from the lalies to south of Glenville from which water discharged down Shell Rock valley.

The moraines are composed largely of clayey till, but they all inciude a few gravelly knolls, and some of them have local development of coarse stony drift with stony loam soil. The till plains, which with their included marshy tracts, occupy about half the surface of the county, have usually a very rich pebbly clay loam soil. The marshes and wet land on the till plain have been already greatly reduced by ditching.

\section{Percentages of Classes of Land in Freeborn County}

Square miles Per cent

Pre-Wisconsin till plain, black clay loam...................... $20 \quad 2.86$

Moraines of Wisconsin drift, chiefly pebbly clay loam soil............ $240 \quad 34.28$

Outwash plains of sandy gravel with sandy to sandy loam soil.......... $60 \quad 8.57$

Till plains, chiefly pebbly clay loam.......................... 3 s0 4.28

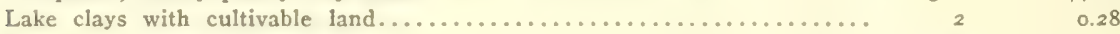

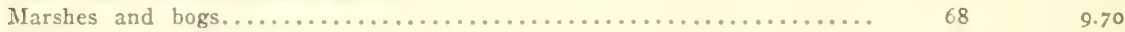

$700 \quad \overline{99.97}$

Farm and Crop Data for Frecborn Connty from Census of 1910

Rural population 14,588 or 20 per square mile

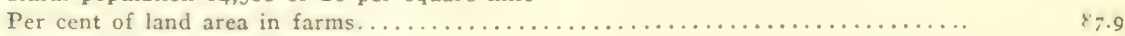

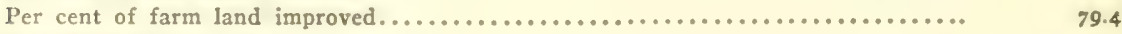

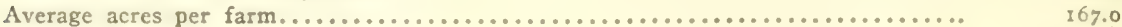

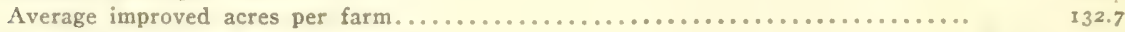

Value of all farm property.................................... \$27,961,397

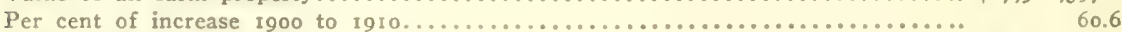

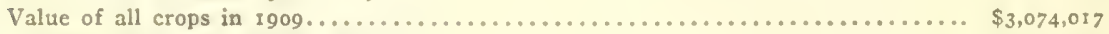

Cereals (corn, oats, wheat, barley, rye)....................... \$2,I56,96I

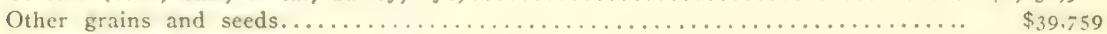

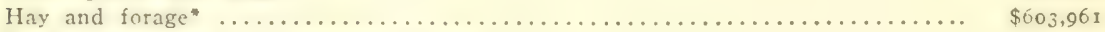

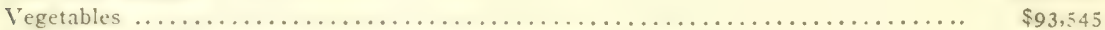

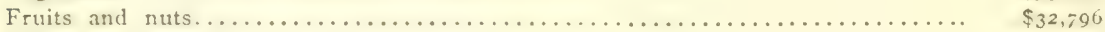

All other crops............................................. $\$ 146,995$

* Tame grass, 76,345 tons; wild grass, 64,550 tons.

\section{FARIBAULT COUNTY}

Faribault County is located on the southern border of the state with Blue Earth as the county seat. The drainage is all northward through Blue Earth River and its tributaries to the Minnesota River at Mankato.

The county is largely a till plain with an altitude above sea level of I,050 feet on the north border and I, I 50 to I,200 feet near the state line. There are, however, weak moraines traversing it, and a very prominent moraine known as the Kiester Hills occupying much of the southeast township. The highest points on these hills are nearly $\mathrm{I},+$, 00 feet. There 
are also sharp knolls and clusters of knolls in the southwest part of the county rising 50 to 75 feet above the plain. Smaller gravel knolls occur 3 to 4 miles north of Bricelyn.

Northeast of Bricelyn there is an old lake bed covering several square miles in which the till is coated to a depth of several feet with sand and silt deposits. It occupies a low plain northwest of the Kiester Hills. Bars and beaches of sandy gravel are found on parts of its shore. This lake seems to have been drained by cutting down of the valley of East Forli of Blue Earth River. It may be remarked in this connection that the flattest parts of the Blue Earth basin seem likely to have been partially submerged for some time after the ice sheet disappeared, for the drainage development is likely to have been very slow.

The till plain has a black clay loam soil, but the moraines have a large amount of gravelly and stony loam, as also do the knolls scattered over the plain.

\section{Percentages of Classes of Land in Faribault County}

Square miles Per cent

Gravelly moraines and knolly drift, stony loam................. $25 \quad 3.47$

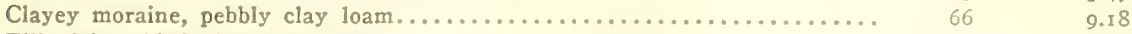

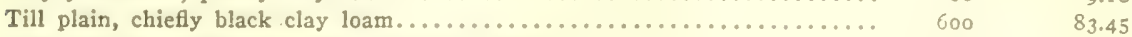

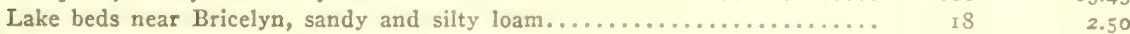

Marshes and bogs including drained lakes..................... 10 1.40

$719 \quad 100.00$

Farm and Crop Data for Faribault County from Census of 1910

Rural population 11,684 or 16.2 per square mile

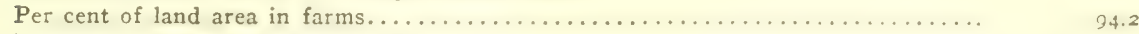

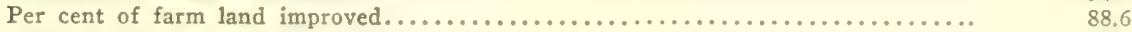

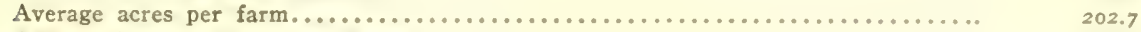

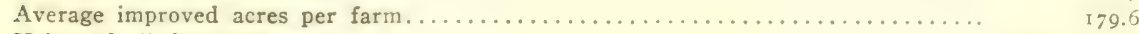

Value of all farm property.................................. \$32,474,072

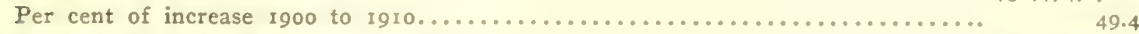

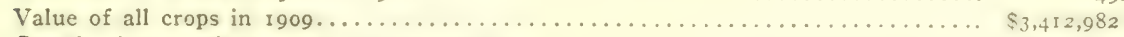

Cereals (corn, wheat, oats, barley, rye) $\ldots \ldots \ldots \ldots \ldots \ldots \ldots \ldots \ldots \ldots \ldots \ldots \ldots \ldots \ldots \ldots \ldots \ldots \ldots \ldots \ldots, 75,6 ; 9$

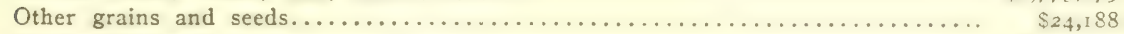

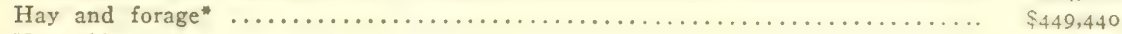

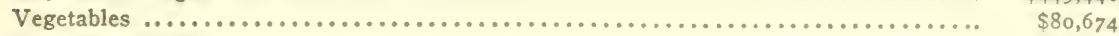

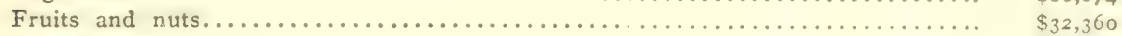

All other crops................................................. $\$ 50,641$

* Tame grass, 32,509 tons; wild grass, 59,235 tons.

\section{MARTIN COUNTY}

Martin County is located on the southern border of the state, with Fairmont as the county seat. Its area, including lakes, is about 723 square miles. The lakes are estimated to cover ig square miles. ${ }^{5}$ The greater part of the county is drained eastward to Blue Earth River, but the southwest part is drained southward into Iowa by an eastern tributary

- The census of 1910 gives a land area of 719 square miles which is 15 square miles too high. 
of the Des Moines River. There are several chains of lakes in Martin County, which have been interpreted by Upham in his report on that county to mark the line of interglacial valleys, which have been irregularly filled by the deposits of the latest or Wisconsin till. The soil separating the Wisconsin till from the older till below it is to be seen in a few places along the bluffs of the lakes.

The suriace slopes gently from southwest to northeast, being about $\mathrm{I}, 400$ feet in the southwest corner, and about $\mathrm{I}, 050$ feet in the northeast corner of the county.

Three morainic belts traverse the county from northwest to southeast, which were formed on the southwest side of the Minnesota valley lobe of the Keewatin ice field. They are all rather diffuse knolly tracts with nearly plane areas inclosed among the knolls and ridges. The middle belt, which traverses the central part of the county, is spread over a width of + to 8 miles, and the others are generally 2 to 4 miles wide. Gravelly knolls are scattered along the moraine, and occur to some extent along the bordering till plain, but the moraines are generally of clayey till. The plains have a rich black clay loam soil, though a small area northwest of Ceylon has a sandy soil.

Percentages of Classes of Land in Martin County

Square miles Per cent

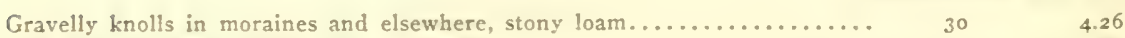

Clay moraines with pebbly clay loam soil...................... $\$ 75 \quad 24.86$

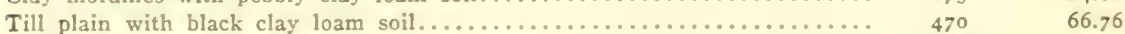

Gravelly and sandy soil on plains and valleys.................... $20 \quad 2.84$

Wet land, marshy and boggy.................................. 9.28

$704 \quad 100.00$

Farm and Crop Data for Martin County from Census of 1910

Rural population 11,453 or 16.3 per square mile

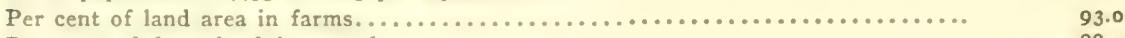

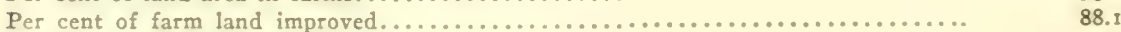

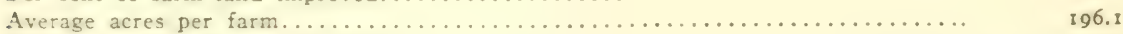

Average improved acres per farm................................ I72.8

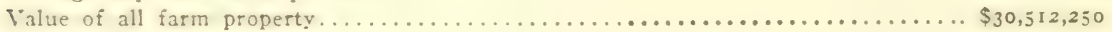

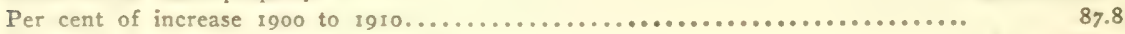

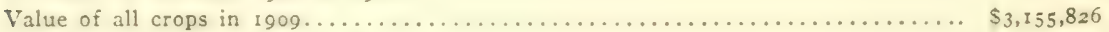

Cereals (oats, corn, wheat, barley, rye)........................ \$2,504,379

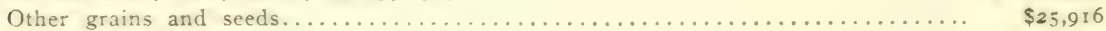

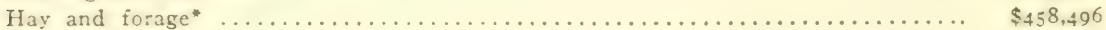

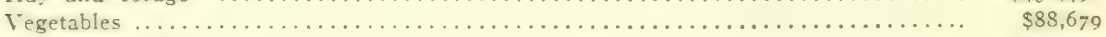

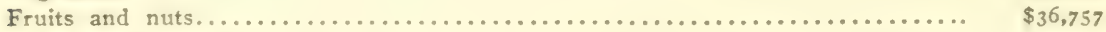

All other crops............................................ \$\$1, 99

* Tame grass, 49,845 tons; wild grass, $49,54 \mathrm{~T}$ tons.

\section{JACKSON COUNTY}

Jackson County, of which Jackson is the county seat, is located on the southern border of the state. The land area is 702 square miles and the lake area about 20 square miles. Heron Lake, a body of water I2 
miles long, lies in the northwest quarter of the county. The drainage is largely by the Des Moines River, the outlet of Heron Lake being northward into the Des Moines. The east part of the county drains to the Minnesota River, while the southwest part is drained by Little Sioux River into the Missouri River drainage.

A prominent moraine on the west side of the Des Moines runs north to south across the county and rises in places above 1,500 feet. A similar altitude above sea level is attained in the extreme southwest part of the county which is crossed by another moraine. There are two weak moraines east of the Des Moines, separated by a till plain about 6 miles wide. A more extensive till plain covers the western part of the county. The moraines are very largely of clayey till. The till plains have a rich black clay loam soil, and portions of the plains in the western part of the county have a thin deposit of silt over the till.

A narrow gravelly strip follows the Des Moines valley for a few miles below Windom, but in the southern part of the county the Des Moines valley has bluffs of till to a height of nearly roo feet above the stream.

Percentages of Classes of Land in Jackson County

Square miles Per cent

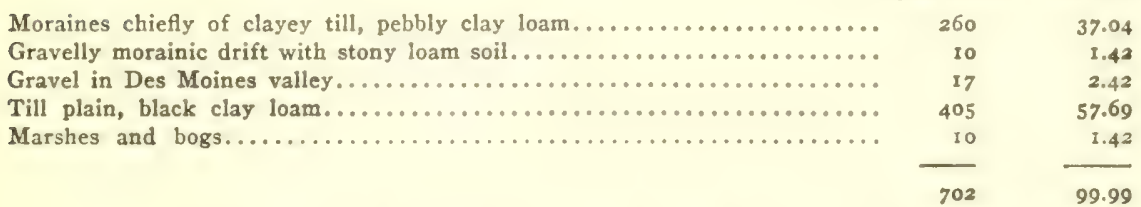

Farm and Crop Data for Jackson County from Census of 1910

Rural population 10,539 or 15 per square mile

Per cent of land area in farms................................... 98.6

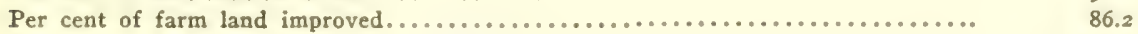

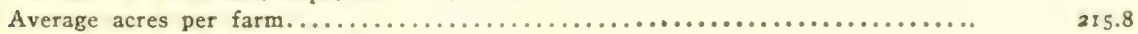

Average improved acres per farm............................... I 86.1

Value of all farm property.................................. \$26,357,716

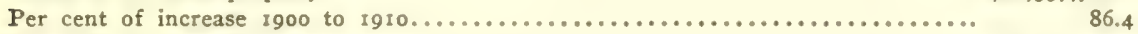

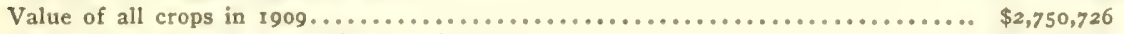

Cereals (corn, oats, barley, wheat, rye)........................... $\$ 2,163,845$

Other grains and seeds........................................ \$92,197

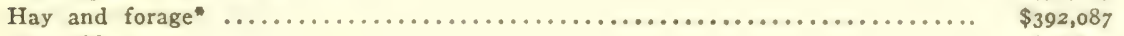

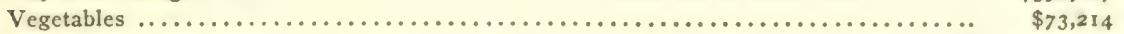

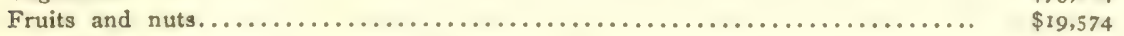

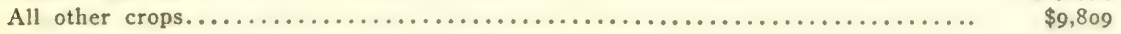

- Tame grass, 48,787 tons; wild grass, 46,386 tons.

\section{NOBLES COUNTY}

Nobles County is located on the south border of the state in southwestern Minnesota, with Worthington as the county seat. The drainage of the northeast part is to the Des Moines River, but the southern and western parts drain southwestward across Iowa into the Big Sioux River, and thence to the Missouri. 
The county is crossed from northwest to southeast by the Coteau des Prairies, its crest passing between Worthington and Rushmore. Much of the crest stands above 1,700 feet, and part of it above 1,750 feet, but its altitude at the state line is 1,650 feet above sea level. There is a gentle slope southwestward from the crest to about $I, 450$ feet in the southwest corner of the county. There is a similar slope to the northeast corner of the county, which also is about I, 450 feet.

Two well-defined moraines which are separated by a narrow till plain $I$ to 5 miles in width, traverse the high part of the Coteau des Prairies across the county. To the east of the eastern or inner moraine is a smooth till plain extending beyond the county limits into Jackson County. To the west of the western moraine a tract of very thin young or Wisconsin drift is found. The drift veneers the eroded surface of an older drift and the present drainage runs in about the same lines as that the interglacial valleys followed.

The pre-Wisconsin or old gray drift, which is exposed in a narrow strip on the southwest edge of the county, contains there a large amount of gravel, and has a thin coating of silt some of which may be wind deposited. A more typical deposit of silt or loess sets in a few miles farther west. The gravel in this old drift is much stained by iron and much more weathered in appearance than the Wisconsin drift. In places within the limits of the Wisconsin drift the old gravel has been gathered up and mixed with the fresh material of that drift. Good exposures of such an admixture are to be seen in Adrian and westward between the village and Kanaranzi Creek. The older till, though more deeply oxidized than the Wisconsin drift, shows only a slight depth of leaching of its calcareous material. A response with acid is usually obtained within two feet of the surface, whereas in drift of similar age in the southeast part of the state there has been leaching to a depth of 4 to 6 feet. The deficiency in rainfall is thought to be the main cause for the slight amount of leaching, as was noted in the general discussion.

The moraines of Wisconsin drift are composed largely of clayey till, but parts of them are of coarse material with a slight loamy admixture, and there are also gravelly knolls. The till plains are of clayey character, and in places have a coating of fine silt loam a few inches thick above the pebbly till.

There are narrow strips of gravelly outwash connected with parts of the border of the prominent moraines of this county. The valleys also that lead southwest from the Coteau des Prairies generally are fringed with narrow gravelly strips. These seem to have been formed in part by glacial drainage, but are being worked over and redeposited by modern drainage lines. 


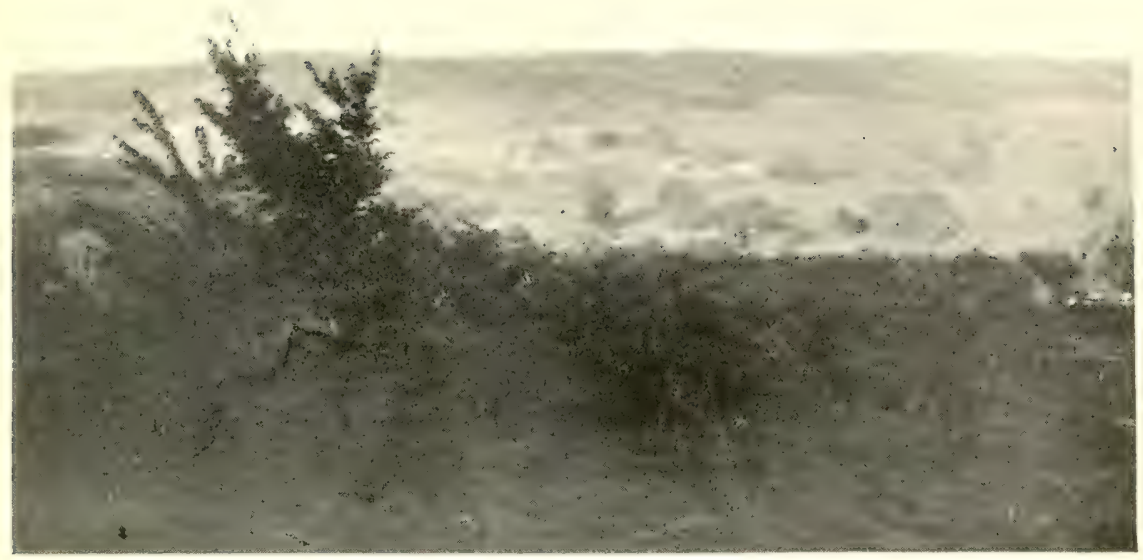

1. ZUMBRO VALLEY NEAR ROCHESTER

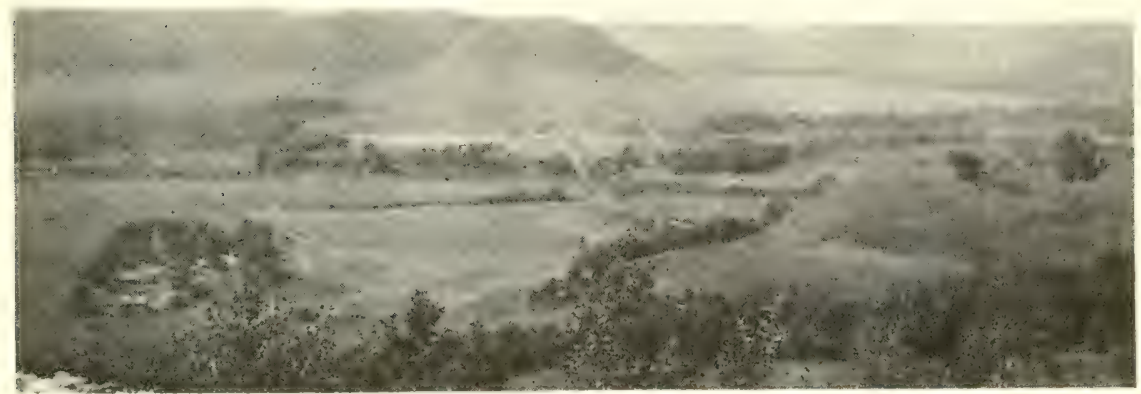

b. VILLEY OF ROLLINGSTONE RIVER NEAR MINNESOTA CITY

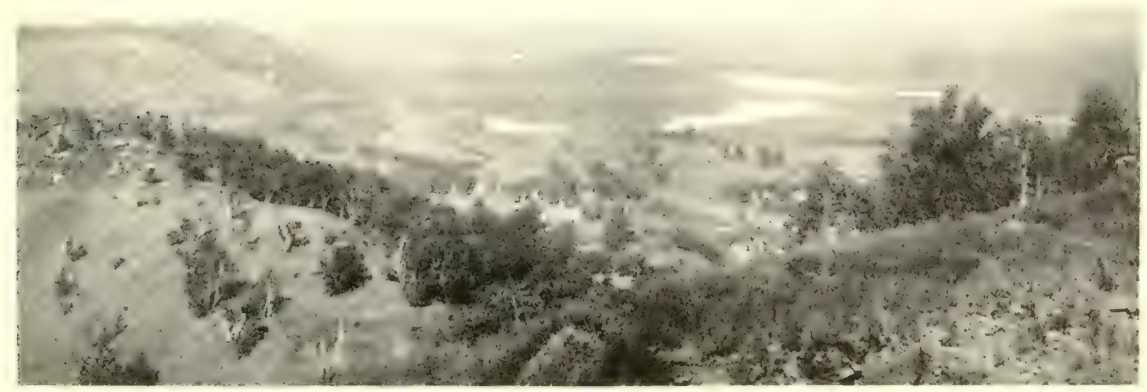

('. MISSISSIPPI VALI.E AT MINNESOTA CITY 

Old or pre-Wisconsin drift, largely gravelly to stony loam........... $66 \quad 9.14$

Moraines of Wisconsin drift, chiefly pebbly clayey loam............ I20 $\quad 16.62$

Wisconsin till plain, largely black clay loam..................... $500 \quad 69.25$

Outwash and valley gravels, gravelly to stony loam................. $36 \quad 4.99$

Farm and Crop Data for Nobles County from Census of toro

Rural population 9,358 or 13 per square mile

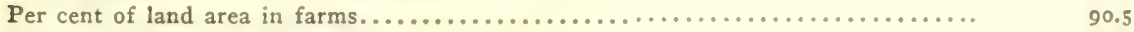

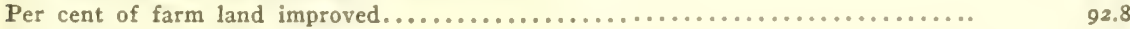

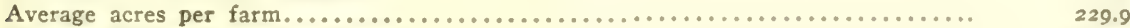

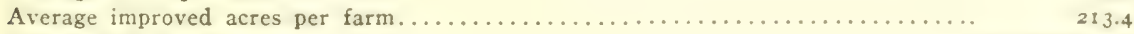

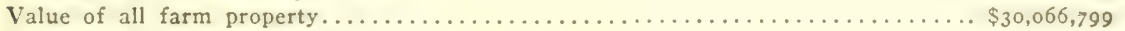

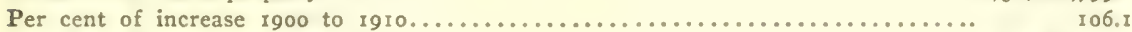

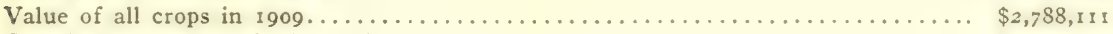

Cereals (oats, corn, barley, wheat, rye)....................... $\$ 2,149,629$

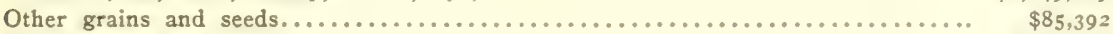

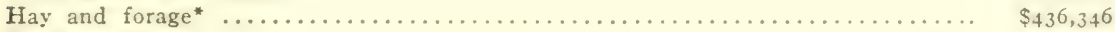

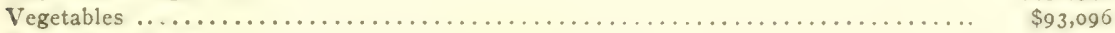

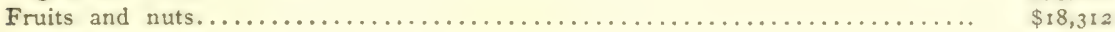

All other crops.................................................... $\$ 5,336$

* Tame grass, 56,284 tons; wild grass, 29,809 tons.

\section{ROCK COUNTY}

Rock County is the southwest corner county of the state, with Luverne as the county seat. The drainage is all southwestward to Big Sioux River. The highest land is a quartzite ridge that runs from near Luverne northward past Hardwick to Trosky, and which stands I,650 to I,750 feet above sea level. The lowest land in the southwest part of the county is about $I, 400$ feet, but on the divide between the streams an altitude of I,500 feet is maintained nearly to the southern end of the county.

The Wisconsin or young gray drift covers only a few square miles in the northeast township, and there it is a thin veneer on the eroded surface of the old gray till. In places it has a slight ridge at the border, such being the case for two or three miles from the north line of the county on the west bluff of Rock River, but usually the drift is only Io to 20 feet thick. There appears to have been a weak outwash from it down the tributaries of Rock River, as well as along Rock River itself.

The old gray drift contains a large amount of gravelly material, but till is interbedded with the gravel and forms part of the surface.

The southwest part of the county has a deposit of loess over the till several feet in depth, or enough to form the soil and subsoil. Elsewhere the cover of silt is thin and discontinuous.

The eastern part of the county east of Rock River has a heavy drift deposit, but the northwest quarter is very thinly coated with drift, and small outcrops of quartzite are numerous. The old till of this county, 
like that of Nobles County, is not deeply leached, but it shows high oxidation, and has been greatly eroded in its thick portions.

Percentages of Classes of Land in Rock County

Square miles Per cent

Old drift with scanty silt cover, soil chiefly a sandy to gravelly loam..... 250

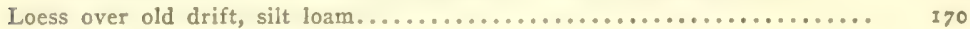

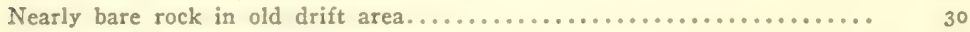

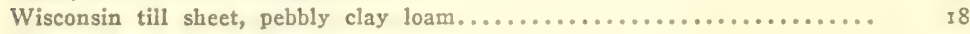

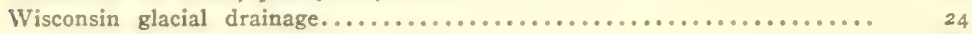

$\frac{24}{492} \frac{4.88}{100.00}$

Farm and Crop Data for Rock County from Census of roro

$50.8 \mathrm{r}$

34.55

6.10

3.66

4.88

Rural population 6,495 or 13 per square mile

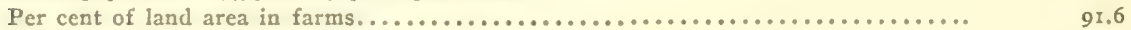

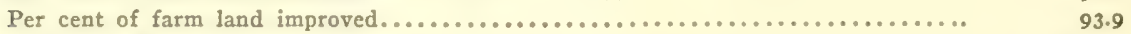

Average acres per farm.......................................... 239...

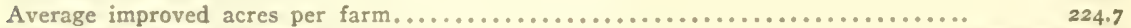

Value of all farm property.................................. \$25,297,625

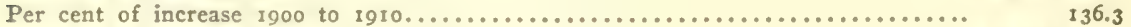

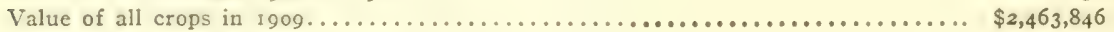

Cereals (corn, oats, barley, wheat, rye)......................... \$2,043,05I

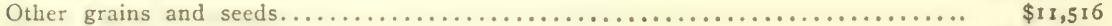

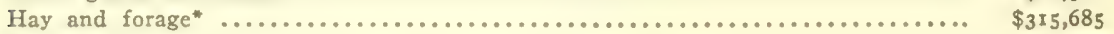

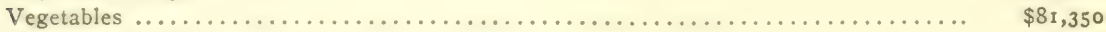

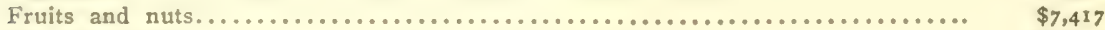

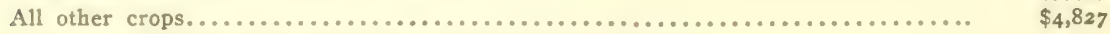

* Tame grass, 38,79 I tons; wild grass, 23,070 tons. 


\section{INDEX}

Adrian, glacial drift near........... 140

Afton, glacial drift near........... 89 Agassiz, Lake...5, 12, 14, 16, 17, 18, 19, 56, $57,58,72,73,74,76,77$, $79,88,97,98,107,111,112$, 130, 131

Agricultural development since $1850 \ldots 58-60$ Agriculture, Department of, University of

Minnesota .................. 4 Aitken County.......9, 12, 17, 49, 50, 64-65 Aitken, glacial Lake.............. I7 Albert Lea, glacial formations near... I35, I36 Alden, glacial moraine near.......... I 35

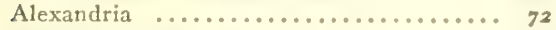

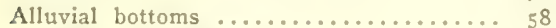
Altitude of Minnesota.............. 6 map ...................... 8

Altitude of south half of Minnesota..... 45

Amboy, glacial formations near........ 123

Annandale, outwash plains near....... 55 Anoka .......................82,86 Anoka County ............9, 53, 60, 86-87

Appleton, glaciation near........... 55 Area of Minnesota................ 5

Arthyde .........................65

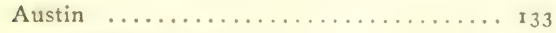

limestone near ............... $2 \mathrm{r}$

Barley ...................6, 60,108

Battle Lake, outwash plain near........ 72

Beardsley, moraine near............ 77

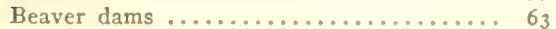

Becker County .................6, 6, crop-growing season ........... $3 \mathrm{I}$

Belle Plaine prairie................. r 04

Benton County .............49, 50, 82.83

Benton, Lake ..................116, 118

Beroun, swamps near..............6 63

Big Sioux River.......II6, I17, I19, I39, I4I

Big Stone County.............. 57, 77-78

Big Stone Lake.......... $0,57,58,76,77$ Blue Earth ................... 1 . 36

Blue Earth County.............55, 122.24

Blue Earth River........................ 37 Bois des Sioux River.......57, 74, 75, 76 Braham, glaciation near....................... 65 Brainerd, glaciation near............ 77,67 Bricelyn, glacial lake features near..... I 37 Brown County ................55, I $13^{-14}$ Brown Valley, glacial lake features near.. I 6

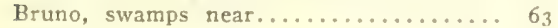
Buffalo ........................ $9_{22}$ Butters, Frederic K., map prepared by... 20 Caledonia, loess near................. r 3 r Cambridge ..................... 85 Cannon River ...........105, 106, 107, ro9 II $1,123,124,125$

Carlton County .................... 14 Carrington loam ............. 107, 109, iro Carver County ........49, 53, 55, 60, 102-3
Cass County ..................9, 50, 68 glacial lake features............. I6 Cedar River .........125, I26, I 33, 134, I35 Center City ................... 87 Cereals, acreage ................... 60 Chanarambrie Creek ............... 119 Chandler, glacial features near.......52, I 19 Chaska ..................... r 102 Chippewa County ................55, 97 Chippewa River .....57,72, 73, 78, 79, 80, 96 Chisago County ...........9, 53, 58, 87-88 Christina Lake .................. 72 Classification of land. See Land Classi. fication

Clear Lake, moraine near........... 112

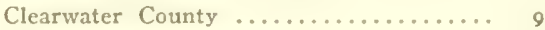
crop-growing season ............ 3 s

Clearwater River ................. 7, 55

Climate, continental ............23.24

Climatic conditions of Minnesota.......23.44

Cold Spring, moraine near..........51, 81

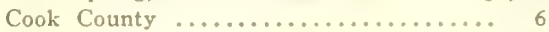

Corn ...........................60

Cortland, moraine near............. 112

Coteau des Prairies.......6, 52, 98, I1 5, 116 II 7, II $8,119,120,140$

Cottonwood County ...........52, 55, 120.21

Cottonwood River ............ I13, 114 , 115

Cretaceous deposits ................ II

Crookston, glacial lake features near..... I 6

Crop-growing season................ 3

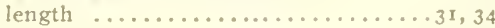
temperature ................ 26

Crow River.....55, 80, 81, 93, 95, 100, 101, 102 Crow Wing County..............67-68 glacial lake features........... I7 Crow Wing River............ $68,70,72$ Dakota County............ I2, 47, 49. I04-I06 Darling Station, esker near.......... 69 Darwin, outwash plain near.........55, 93 Deerhorn Creek.................... 74 Des Moines lobe.................. ror Des Moines River........119, 120, 121, 138, 139 Dodge County ............ I5, 46, 47, $126-27$ agricultural conditions........... 60 Douglas County........... 51, 54, 55, 72-73 Drainage, dendritic............... 106 Drainage, importance............... I 8 Drainage of Minnesota............ 6-7 Drainage of south half of Minnesota..... 45 Drift ................ $9,12,14,53-142$ Illinoian $\ldots \ldots \ldots \ldots \ldots \ldots \ldots \ldots \ldots$ Iowan ....................4. Kansan ................47, 48.49 Labradorian .................. 50 old gray..................... 47 old red.........................48.49 Patrician .................... 40.50 pre.WVisconsin ............... 4 r. 47 


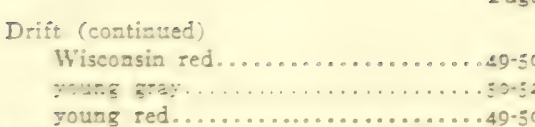

Driftless area...............2, 10, 18, $45-46$

Duluth, settlewent.................59-60

Duluth, Lake............... $14,16,17,63,88$

Buluth, rainy days................. 4 th

Dure sands........53-54,69, 83,84,85,85,88

Eden Valley, moraines near..........54, $5 \vdots$

Elbow Lake...................... 73

Elk River....................8. 82, 8,

Elysias, glacial featutes near.........11r, 123

E!ystan. Lsis . ................ : 24

Embarzass River, glacial ieatures near... I6

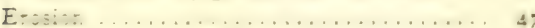

in prairie and forest............ rg

Eskers ..................49,69, 83

Fai:-.... :

Fargo loam ...................1?0, 123

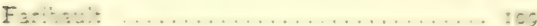

Faribault County................ $55,135-37$

Farmingron, loes zeposic near......... ro6

Feldspar, weathering................ is

Fergus Falls....................... 7

Filleore County............. $15,46,132-33$

Fires, rorest

efiect on soil..................2t-22

Hinckley fire.................22, $6_{3}$

Foley, es'rer near.................. 83

Forest and prairie, map showing........ 20

Forest City, glacial lake fomation....... 94

Forest fires. See Fires

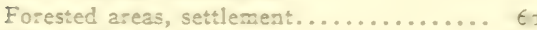

Fort Ripley, dune sand near..........6 60

Foxhome, soil near................ $z$

Freebom County ............ $33,60,135-36$

Freeborn Lake...................... I . 135

Fremont, soil near................. 1 . 130

Frosts, killing, average date of first and

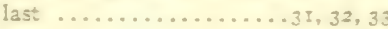

Frtit-growing .................. 8

Gaylozd ........................ sox

Genera Lake. ........................ I3:

Geological Surrey. See Minnesota Geo-

logical Surrey and L-nited

States Geological Surtes

Geolozy, suriace..................... 10-18

Glacial deposits................... I2 See also Drit:

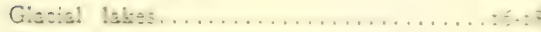

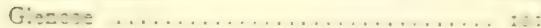

Glesville, outwash plain near........... Ist

Gleawood ...................... $\tau$

Goodhue County........ $55,46,47,49,60$, 106. Granger, quartz formations near........ I32 Granite Falls, formations near.......... gr Granite outcrops............83, 97,08, 100 Grant County................... $57,-3-7,4$ Sicus: $:=$ :

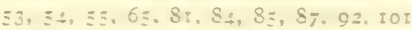

Page

Gray Eagle, moraines near............. 70

Grees Lake, moraines rear............ 9

Hadley, moraine near............... 149

Hampton, red drift near.............. 10 s

Hanley Falls, drainage near........... $\$ 6$

Hardwick, quartzite ridge............. 34 ?

Fisrris ..................... 8 g

Hartland, moraines near............. 233

Hastings ... . . . . . . . . . . . . . . . . . . . . ro4

Hay .......................6.60,89

Hennepin County.....9, 49, $53,55,58,60,93-92$

Heron Lake........................ 38 ...39

Hinckley forest fire................22, $6_{3}$

Houston County..........2, 12, 46,60, $83 \pi-32$

Hubbard County..................... 9

crop-groxing season.............. 32

glacial features................. I6

Hudson Bay drainage systew..........6.7

Humidity, meas relative.............. 43

Huran, giacial lake.............. I

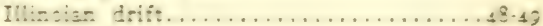

Improved land................... $6 r$

Interglacial ralleys...66,69, $71,74,78,79,83,119$

Ic

Isanti County. . . . . . . . . . . . . .9, $53,85-86$

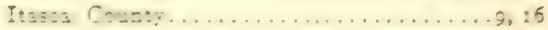

Jackson County.............. \$2, 121, $338-39$

Kanabec County.................49,65-66

Kanazazi Creek.................. 140

Kandirohi County..........54,55,80, 94, 95-95

kighest temperature in............ 25

Kansan drift................46-47, 10

Keewatic ice sheet......9, 12, 15, 17, 49, 53-1 12

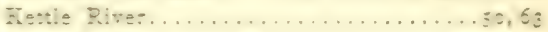

Kiester Hills.................... 136, 137

Kimball, moraines near............54,55,8t

Kingston, glacial lake features near....55,94

Rlossner, moraines nea................ I12

Krox si........................ sor

Koochiching County ............... 6, 22

Labrador ice sheet................15,49,50

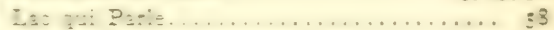

Lac qui Parle County................55, 98

Lac qui Parle River.................... gs

Lake City, glacial drift near............ I28

Laise dezssis ................ Is

Lake of the Wocds................... s, I6

La'seland, glacial deposits neaz......... 58

Lakes, glacial ................... r6-18

Lakes of Mingesota.................. I5 area ..........................

Land classification ............... $53^{-1442}$

Leaching ........19, 46, 105, 107, 132, 134, 140 Leat Hills ...................6, 73

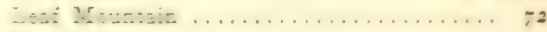

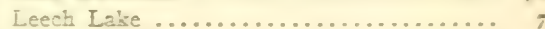

Leech Lake $\mathrm{D}_{\mathrm{am}}$, climate.............25, s0

Le Stuetr Certer................... rit

Le Sueut County.................53, 111-12

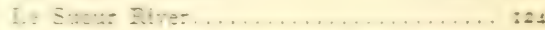

Limestone, leachinz. See Leaching 


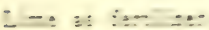

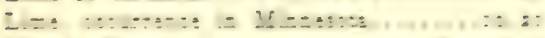

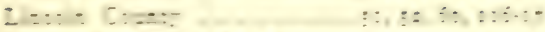
L z-t

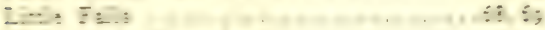

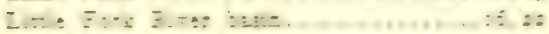

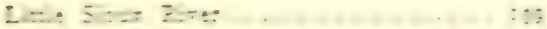

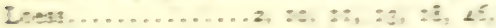

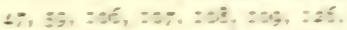

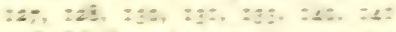

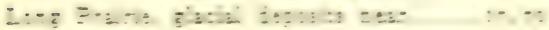
Z..

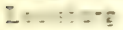

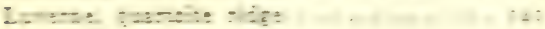

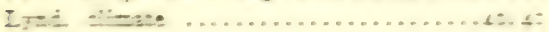

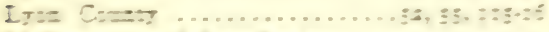

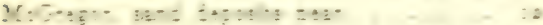

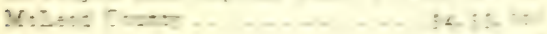
$\mathrm{YC}:-\cdots \mathrm{O}$

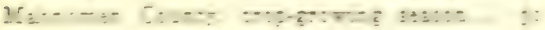

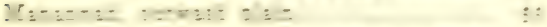

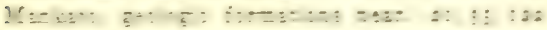

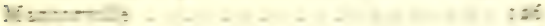

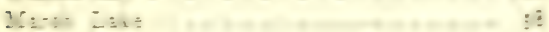

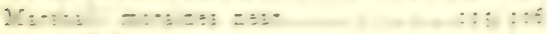

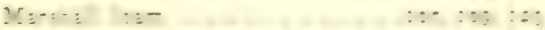

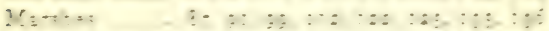

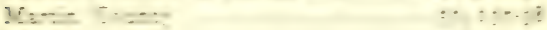
$\because: 3=-$

$\because \div+\div \div-\because \cdot-\cdots$

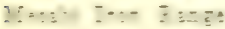

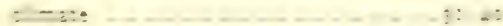

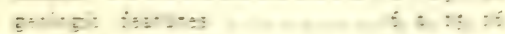
Un:t:

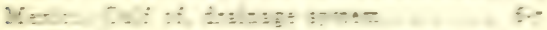

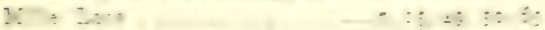

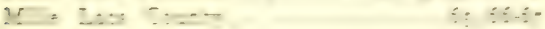

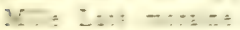

$\therefore-\cdots: \cdots ;$

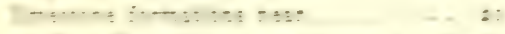

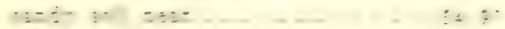

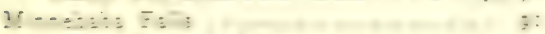

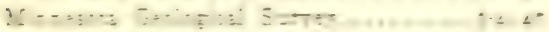

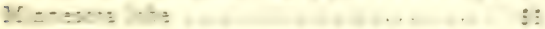

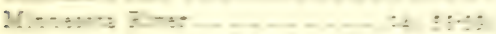

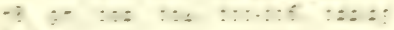

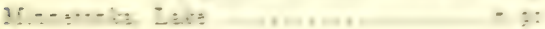

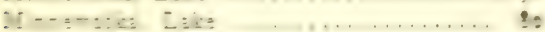

$\because \cdots,-\cdots, \ldots+\cdots \cdots$

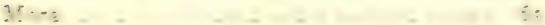

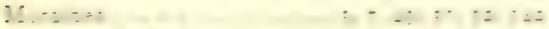

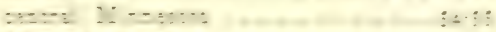

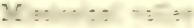

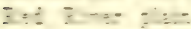

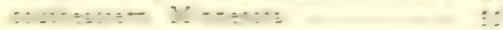

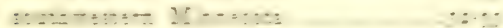

Y...

3.....

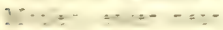

IS:=er $\mathrm{C}:=$

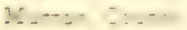

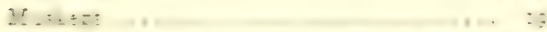

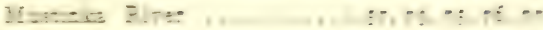

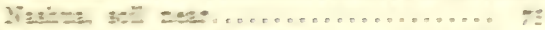

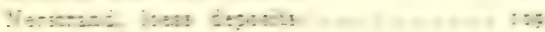

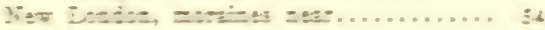

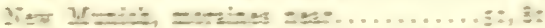

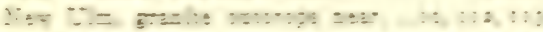

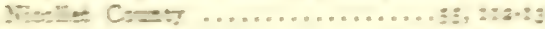

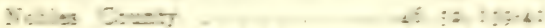

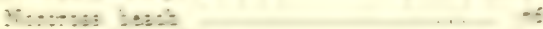

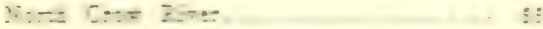

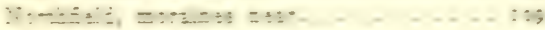

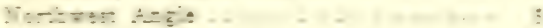

-

I

C.TS

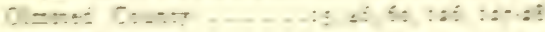
-

tons: Gike

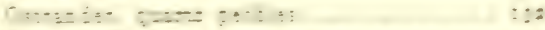

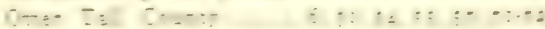

1-?: I: Zase

C-s= Z3 Zre

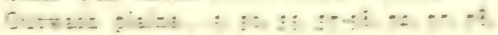

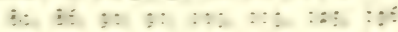

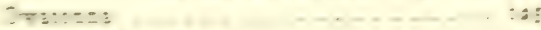

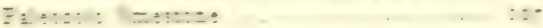

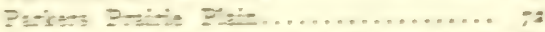

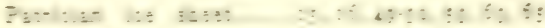

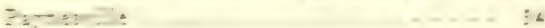

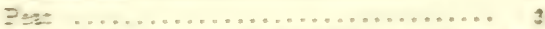

Z::- Lare 0 : $:$ :

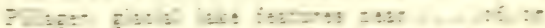



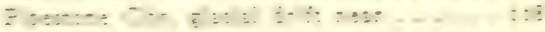

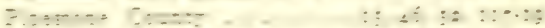

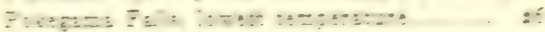

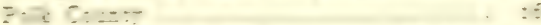
Z- - :

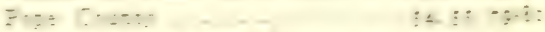

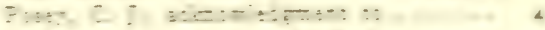
z:

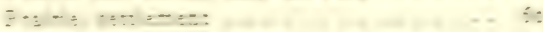

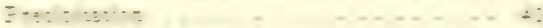

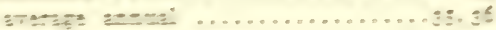

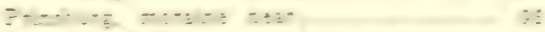

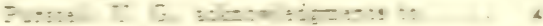

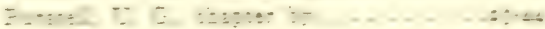
$\therefore-\ldots \ldots+\ldots: \theta_{L}$

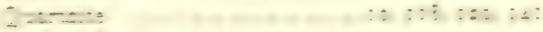
$7: \cdots: \because+\infty)$

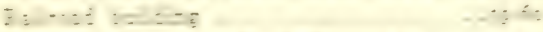

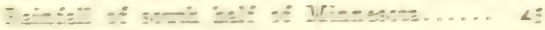

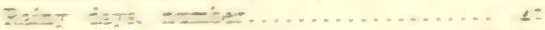

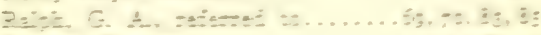

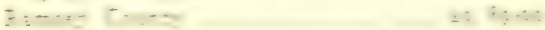
$\because: \cdots \cdots \ldots \ldots \ldots \ldots \ldots \ldots \ldots \ldots \ldots \ldots \ldots$

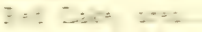

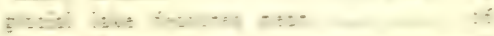

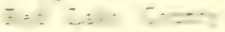

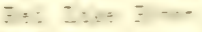

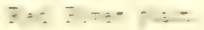


Red River...6, 7,9, $14,18,71,73,75,76,77,78$ Red Wing, altitude............ 106, 107 Redwood County...............55, I1 4 .15 Redwood Falls, granite outcrops near.... II5 Redwood River ................56, 114-15 Relief of Minnesota............... 6 Renville County .............55,95, I00 Residuary material .................. II Rice County .............47,53, 109-1 Rochester ................... 127 Rock County ........15, 46,52, 118, 141-42 Ronnely, esker near.............. 83 Root River ..........126, 127, 131, 132, I33 Round Prairie, gravel plains near....... 70 Royalton, dune sand near............ 69 Rum River............65, 66, 82, 84, 85 Russell, gravel knolls near............ II 6 Rye ....................... 60

St. Anthony Falls................ gr

St. Charles, loess near............... r 30

St. Cloud, red drift near............. 8

St. Croix River...7, 12, 17, 50, 53, 58,63,81, 87

St. Croix, Lake................. 58

St. Francis River.................. 84

St. James, soil near................. 122

St. Lawrence, Gulf of, drainage system... 6.7

St. Louis County...................................... 22

St. Louis River................ $7,11,15$

St. Paul ................... 54,89, 90

St. Peter, glacial drift near............ I I 2

St. Peter sandstone................ I09

Sand dunes ..............53,54,69,83,86

Sand, wind-blown ............... II

Sandstone outcrops ................. Io

Sauk Center, moraine near............ 5 I

Sauk Rapids, granite outcrops near...... 83

Sauk River ..........51,55, 70, 80,81, 93

Savage, dune sand near............ 104

Sawtooth Range ................. 6

Scott County ............49,58, 103.4

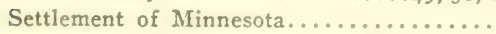

….59-60, 104.5, 106, 129, I 33

Shakopee prairie ................. 104

Sherburne County ..........53,60,82, 84-85

Shetek, Lake ...................... 120

Sibley County .................55, 101-2

Sink holes ...................... 134

Sioux loam ................. I1

Sioux River .................... I17

Slayton .................... I19

Snake River ...................... 65

Snowfall ...................40,41 Soil

See also Land classification

central Minnesota ............... 55

definition .................. I

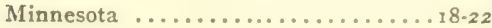

outwash plains..................57-58

southeastern Minnesota .........53,54 southwestern Minnesota ........... 53

survey .................... 58
Soils, Bureau of, referred to........... …..... 107, 108, 109, I10, I23 Soils, Division of, University of Minnesota $\ldots \ldots \ldots \ldots \ldots \ldots \ldots$.......... 4

South Haven, outwash plains near..... 55 Stearns County ....49,5 I, 55, 80, $81-82,94,95$ Steele County ................53, 125.26 Stevens County ..............57, $78-79$ Stillwater .................2I, 58, 88 Straight River ................ r 25 Striations, glacial .............. 47

Sturgeon Lake .................... 56

Sunrise River ................ 87 Superior, Lake .............6, 7, 14, I5 influence on climate.........23, 31,44 Superior lobe .................. $50,63,65$

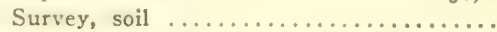

See Soil Survey and Land classifica. tion

Swamps ............. $3,63,64-65,75,93,94$ drainage ...................... 60

Swan River .................... 70

Swift County ........ 54,55,57,79,96-97 Temperatures

average seasonal .............. 3 I

highest known ................. 26, 29

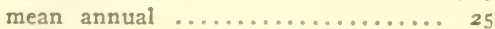

mean January ................26,27

mean July ................. 26, 28 monthly and annual mean........ 26

Till plains ............. $12,18,53,63 \cdot 142$ Tintah, swamps near............. 75 Tintah beach ..................... 76 Todd County ......... $6,49,50,51,70-71,73$

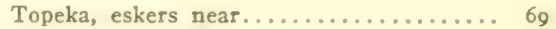
Topography of Minnesota........... 5 Traverse County ............. 57, 75.77 Traverse, Lake ..............16, 73, 75, 76

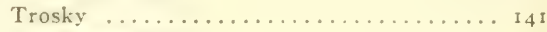
Truck gardening ................... 92

United States Bureau of Soils.......... 4 United States Geological Survey....... 3.4 United States Weather Bureau........., 24 Upham, glacial Lake.............. I7 Upham, Warren, referred to. $.4,17,20,52$, I $_{3} 8$ Upper Iowa River..........131, 132, 133, r 34 Vermilion Iron Range, crop-growing sea-

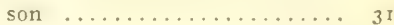

Vermilion River ................. 103, Iс5 Wabash silt loam................ r 08 Wabasha .................... 128 Wabasha County .......... I5, 46, 60, 128-29

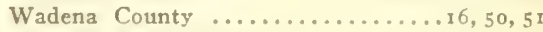
Wadena, glacial Lake.............. 16 Waseca County ................53, 1 24.25 Washington County .............49, 88-89

Watab, granite outcrcps............. 83 Watkins, young gray drift........... 54 Watonwan County .......... 55, 56, 121-22 Watonwan River ...........113,121, 123 Waukesha loam .................. ro8 
Weather Bureau. See United States Weather Bureau

Weathering

WVheat

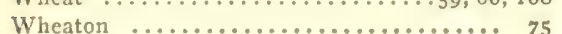

White Bear Lake................. 88

Whitewater River ............... I 27

Wilkin County ...............57, 74.75

Willmar County ................ 95

Winchell, N. H., referred to........... I7

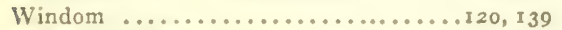

Winds, prevailing ..............40,42

Wind deposits ..................1 2
Winnibigoshish, Lake ............ 7 Winona County ........2, 12, 15, 46, 129-31 Wisconsin drift. . . 51, 63-64, 66, 69, 70,7I, 88 , 106, 108, 109, I1 8 , I19, I26, I3 I, I34, I35, I38, I40, I4I Worthington ................. 139 , 140

Wright County....9, 49, 53, 54, 55, 60, 92.93, 94 Yellow Bank River................. 98 Yellow Medicine County.......52,55,56,99 Yellow Medicine River.............. 56 Zumbro River ................ ro6, $107,109,125,126,127,128,129$

Zumbrota, glacial drift near.......... 107 








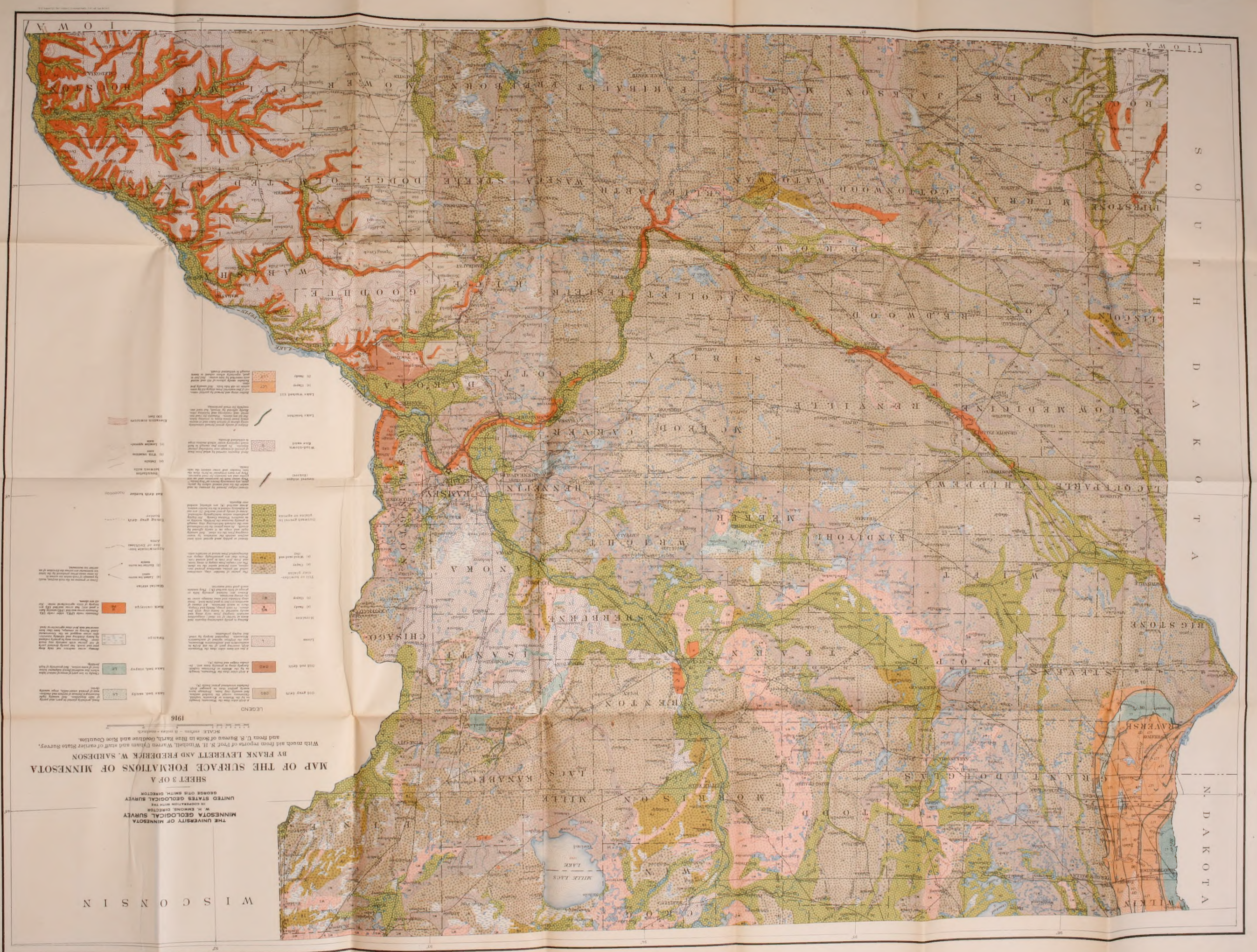




\section{LIBRARY OF CONGRESS}

||||||||||||||||||||||||||||||||||||||||||||

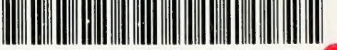

o $003 \quad 1386627$ 